Avaliação da concentração de elementos traço e respectivos mapas de distribuição em placenta bovina

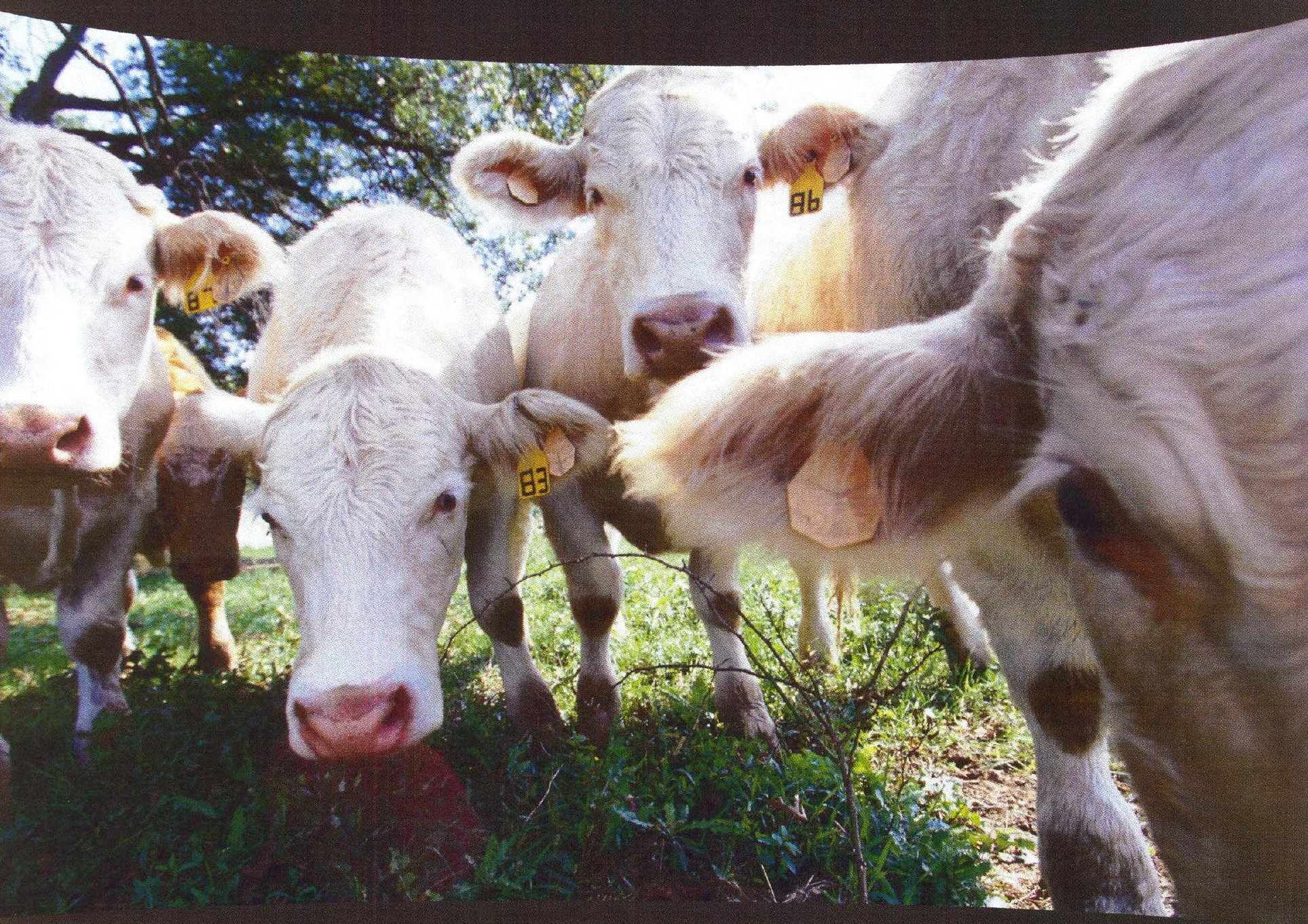




\section{Avaliação da concentração de elementos traço e respectivos mapas de distribuição em placenta bovina}

Dissertação apresentada ao Programa de Pós-

Graduação em Anatomia dos Animais Domésticos e Silvestres da Faculdade de Medicina Veterinária e Zootecnia da Universidade de São Paulo para obtenção do título de Mestre em Ciência.

\section{Departamento:}

Cirurgia

Área de concentração:

Anatomia dos Animais Domésticos e

Silvestres

Orientador:

Prof $^{a}$. Dr $^{\mathrm{a}}$. Andrea Antunes Pereira

\section{São Paulo}


Autorizo a reprodução parcial ou total desta obra, para fins acadêmicos, desde que citada a fonte.

DADOS INTERNACIONAIS DE CATALOGAÇÃO-NA-PUBLICAÇÃO

(Biblioteca Virginie Buff D’Ápice da Faculdade de Medicina Veterinária e Zootecnia da Universidade de São Paulo)

Will, Sonia Elisabete Alves de Lima

Avaliação da concentração de elementos traço e respectivos mapas de distribuição em placenta bovina / Sonia Elisabete Alves de Lima Will. -- 2010. $153 \mathrm{f}$ : : il.

Dissertação (Mestrado) - Universidade de São Paulo. Faculdade de Medicina Veterinária e Zootecnia. Departamento de Cirurgia, São Paulo, 2010.

Programa de Pós-Graduação: Anatomia dos Animais Domésticos e Silvestres. Área de concentração: Anatomia dos Animais Domésticos e Silvestres.

Orientador: Profa. Dra. Andrea Antunes Pereira.

1. Placenta. 2. Elementos traços. 3. Fluorescência de Raios X. 4. Deficiência mineral. Placentônio. I. Título. 


\section{FACULDADE DE MEDICINA VETERINÁRIA E ZOOTECNIA}

\section{CERTIFICADO}

Certificamos que o Projeto intitulado "Avaliação da concentração de elementos traço e respectivos mapas de distribuição em placenta bovina", protocolado sob o $n^{\circ}$ 1704/2009, utilizando 30 (trinta) bovinos, sob a responsabilidade da Profa Dra Maria Angélica Miglino, está de acordo com os princípios éticos de experimentação animal da Comissão de Bioética da Faculdade de Medicina Veterinária e Zootecnia da Universidade de São Paulo e foi aprovado em reunião de 19 de agosto de 2009.

We certify that the Research "Assessment of the concentration of trace elements and their distribution maps bovine placenta", protocol number 1704/2009, utilizing 30 (thirty) bovines, under the responsibility Profa Dra Maria Angélica Miglino, agree with Ethical Principles in Animal Research adopted by Bioethic Commission of the School of Veterinary Medicine and Animal Science of University of São Paulo and was approved in the meeting of day 08/19/09.

São Paulo, 24 de agosto de 2009

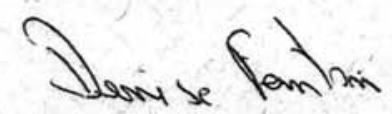

Profa Dra Denise Tabacchi Fantoni

Presidente da Comissão de Bioética FMVZ/USP 


\section{FOLHA DE AVALIAÇÃO}

Nome: WILL, Sonia Elisabete Alves de Lima

Titulo: Avaliação da concentração de elementos traço e respectivos mapas de distribuição em placenta bovina.

Dissertação apresentada ao Programa de Pós-Graduação em Anatomia dos Animais Domésticos e Silvestres da Faculdade de Medicina Veterinária e Zootecnia da Universidade de São Paulo para obtenção do título de Mestre em Ciência.

Data:

\section{Banca Examinadora}

Prof. Dr. Instituição:

Assinatura: Julgamento:

Prof. Dr. Instituição:

Assinatura: Instituição:

Prof.Dr Instituição:

Assinatura: Instituição: 
Epigrafe

“O valor das coisas não está no tempo em que elas duram, mas na Intensidade com que acontecem. Por isso existem momentos Inesquecíveis, coisas "inexplicáveis e pessoas incomparáveis." 


\section{Q Dedicatória}

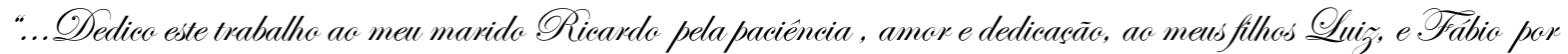
me encherem de orgullho e sempre me ajudarem, a minha nora OSha Oaula que me deu a melhor presente do mundo meu nelinho Soño Olucas, Obrigada por tudo..." 
"... a toda minha famélia que entenderam e respeitaram minhas ausências para melhor execusão de men trabalho... Obrigada por tudo..." 


\section{STyradecimentes}

À minha orientadora Profa. Dra. Andrea Antunes Pereira, em primeiro lugar por abrir a porta para o mundo científico, e pela confiança em mim depositada. Muito obrigada pela paciência, compreensão, amizade e experiência.

À Profa. Dra Maria Angélica Miglino, pela oportunidade, confiando-me a execução deste projeto, obrigada pelo precioso ensinamento. Tenho muito orgulho de ter sido sua aluna e ter feito parte de sua equipe.

À $\mathfrak{D r}^{a}$ Rose Eli Grassi Rici, uma grande mulher e pesquisadora, obrigada pelos conselhos, ensinamentos e amizade e por todo o auxilio para a realização deste trabalho. Muito obrigada por compartilhar comigo seus conhecimentos.

A minha amiga e companheira da Pós-Graduação Michelle Barbosa, que compartilhou todos os momentos alegres e difíceis desta jornada, se mostrou uma pessoa maravilhosa, de grande coração, por me ajudar quando mais precisei me escutar em especial por ser minha amiga.

A minha amiga e companheira da Pós-Graduação Patrícia Jesler, que juntas conseguimos ultrapassar várias barreiras, obrigada por todo carinho, por passar junto comigo todos os momentos difíceis e os alegres, muito obrigada por sua amizade.

Ao Dr. Eduardo Brescansin de Amóres pelo auxílio na elaboração dos mapas de distribuição elementares e por todo o auxilio para a realização deste trabalho.

A todos os docentes do Departamento de Anatomia dos Animais Domésticos e Silvestres da FMMVZ-USP, pelo ensinamento e amizade.

Aos meus amigos de Pós-Graduação Joãozinho, Luis, Carol, Isabella, Dayane, Phelipe, Dilayla, Myrian, Rafael, Sarmento, Marcos, Renata, Lorena, Álvaro, Rodrigo, Greyson, Matheus, Vivian, Lisley, Fabieli, Miler, Camila, Juliana, Andre, Marina, Claudinha, Joana, Renata Silva, desculpem os nomes não citados, e que não consegui lembrar de todos, mas obrigados a todos que conheci e que fizeram parte deste momento muito importante de minha vida sobretudo pela amizade. 
A secretaria do Departamento, especialmente a Jaqueline Martins e ao Maicon, sempre atenciosos e prestativos.

Aos funcionários Ednaldo Ribas Farias (Índio), Ronaldo Agostinho e ao Diogo Nader Palermo, por estarem sempre dispostos a ajudar.

Ao Laboratório LAFACC, do ICBIII- Obrigada Prof. Dr. Silvia Boldrini e Prof. Dr. Edison Liberti pelo apoio e conhecimento para desenvolvimento do projeto, aos Pós- graduando Thiago, Ricardo, Walquiria, Paulo, Regina, Marcelo, Ricardo, e outros, obrigada a todos pela amizade e companheirismo.

Ao Laboratório de Fluorescência de raios X no Centro de Química e Meio Ambiente-CQMA-IPENDR. Marcos Antonio Scapin, Obrigada por abrir a porta de seu laboratório para a realização deste projeto, sempre com incrivel disposição em ajudar e ensinar.

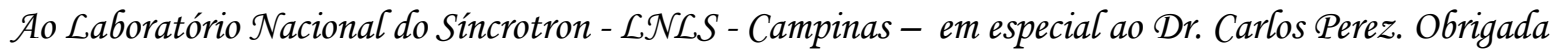
pelo suporte e orientações, e pela oportunidade de trabalfar com um equipamento de alta tecnologia, essenciais a este trabalho, Projeto $n^{\circ} 6526$ - Proposta D09B-XRF-9407, D09B-XRF-10030.

Ao Laboratório de Produtos Funcionais - do Departamento de Engenharia de Alimentos da Faculdade de Zootecnia Pirassununga- USP. Dr. Marcelo Thomazini, Obrigada por abrir a porta de seu laboratório para a realização deste projeto.

À Coordenação de Aperfeiçoamento de Pessoal de Sïvel Superior (CAPES) pela concessão da bolsa que me permitiu concluir com êxito esse nível de formação. 


\section{RESUMO}

WILL, S. E. A. L. Avaliação da concentração de elementos traço e respectivos mapas de distribuição em placenta bovina. [Determination of trace elements and their distribution maps in bovine placenta]. 2010. 153 f. Dissertação (Mestrado em Ciências) - Faculdade de Medicina Veterinária e Zootecnia, Universidade de São Paulo, São Paulo, 2010.

O desenvolvimento sadio e harmonioso de uma gestação está relacionado diretamente a nutrição fetal equilibrada. Alguns minerais são essenciais por meio das funções desempenhadas no metabolismo, manutenção e crescimento fetal. As carências minerais estão entre os fatores que mais contribuem para a baixa produtividade de rebanho, gerando perdas econômicas significativas. Desse modo estudos que auxiliam na compreensão das razões para a baixa produtividade em rebanhos são importantes. A placenta atua como uma barreira seletiva ao fornecimento adequado de nutrientes durante a gestação. O principal objetivo deste estudo foi determinar a concentração de elementos traço para animais não manipulados (GCO) e clonados (GCL) para períodos gestacionais e obter mapas de distribuição qualitativos para placenta de bovinos GCO e GCL. As amostras de tecido placentário foram selecionadas e agrupadas em três períodos gestacionais: estágio 1, 90 dias; estágio 2, 135 dias e estágio 3, 235 dias. Todas as amostras foram analisadas para os elementos constituintes e traço por Espectrometria de Raios X. Os resultados obtidos nas análises de tecido placentário contendo elementos constituintes e traço indicaram que os procedimentos de preparação foram adequados. Os resultados obtidos indicaram variações significativas para os elementos $\mathrm{Na}, \mathrm{Mg}, \mathrm{P}, \mathrm{Cl}, \mathrm{K}$ e Ca. Os mapas de distribuição elementar confirmaram que a maior concentração elementar ocorreu na região de interdigitação entre as criptas carunculares do epitélio uterino e as vilosidades cotiledonária com células trofoblásticas na região dos placentônios e nas glândulas endometriais da região interplacentomal, indicando que nestas regiões intensificam-se as trocas de nutrientes entre mãe e feto. Para os resultados obtidos na avaliação dainterelação elementar, quanto as amostras de placentônio bovino clonado observou-se as interelações entre $\mathrm{Ca}-\mathrm{Fe}, \mathrm{Cu}-\mathrm{Fe}, \mathrm{Zn}$ $\mathrm{Ca}, \mathrm{Fe}-\mathrm{Zn}, \mathrm{Ca}-\mathrm{Cu}$ e $\mathrm{Cu}-\mathrm{Zn}$. Pelo exposto acima, concluiu-se que as análises químicas foram adequadas para a determinação da concentração de elementos constituintes e traço e que a análise qualitativa dos mapas bidimensionais e mapas de correlação obtidos por meio de 
experimento com radiação Síncrotron foram essenciais para a discussão sobre as alterações nas regiões selecionadas e períodos de gestação avaliados.

Palavras chave: Placenta. Elementos traço. Fluorescência de Raios X. Deficiência mineral. Placentônio. 


\begin{abstract}
WILL, S. E. A. L. Determination of trace elements and their distribution maps in bovine placenta. [Avaliação da concentração de elementos traço e respectivos mapas de distribuição em placenta bovina]. 2010. 153 f. Dissertação (Mestrado em Ciências) - Faculdade de Medicina Veterinária e Zootecnia, Universidade de São Paulo, São Paulo, 2010.
\end{abstract}

The healthy and harmonious development of a gestation is directly associated to a balanced fetus nutrition. Some minerals are essential because of their functions developed in the metabolism, maintenance and fetus development. Mineral deficiencies are among the factors that contribute the most for a low productivity of the cattle, generating significant economic loss. Thus, studies that help understand the reasons for a low productivity in cattle are important. The placenta works as a selective barrier to the adequate supply of nutrients during the gestation. The aim of this study was to determine the concentration of trace elements for non-manipulative animals (GCO) and cloned animals (GCL) for gestational periods and to obtain maps of qualitative distribution for the placenta of bovines GCO and GCL. Samples of placenta tissues were selected and grouped in three gestational periods: stage 1, 90 days; stage 2, 135 days; and stage 3, 235 days. All the samples were analyzed for the constituent elements and traces by X Rays Spectrometry. The results obtained in the analyses of placenta tissue bearing constituent elements and trace indicated that the procedures of preparation were adequate. The results indicated significant variations for the elements $\mathrm{Na}, \mathrm{Mg}, \mathrm{P}, \mathrm{Cl}, \mathrm{K}$ e $\mathrm{Ca}$. The maps of elementary distribution confirmed that the highest elementary concentration occurred in the region of inter-digitation of carunculate vaults of the uterine epithelium and cotiledonary vilosities with trophoblast cells, in the regions of the placentons and endometrial glands of the interplacentomal region, confirming that, in these regions, nutrient exchanges intensify between mother and fetus. For the results obtained in evaluation of the elementary interrelation in relation to the samples of cloned bovine placentons we observed that the maps demonstrated several interrelations between $\mathrm{Ca}-\mathrm{Fe}, \mathrm{Cu}-\mathrm{Fe}, \mathrm{Zn}-\mathrm{Ca}, \mathrm{Fe}-\mathrm{Zn}, \mathrm{Ca}-\mathrm{Cu}$, and $\mathrm{Cu}-\mathrm{Zn}$. By these results, we concluded that the chemical analyses were adequate for the determination of the elementary concentration of constituent elements and trace and also that the qualitative analysis of the bi-dimensional maps and correlated maps obtained through experiments with Synchrotron radiation were 
essential for the discussion on alterations on selected regions and on evaluated periods of gestations.

Keywords: Placentae. Trace elements. X Ray Fluorescence. Mineral Deficiency. Placentons. 


\section{LISTA DE ILUSTRAÇÃO}

Figura 1 - Mecanismo de transporte de minerais através do tecido placentário (1). Direção do fluxo de sangue materno (2). Direção de transferência entre a placenta e o sangue fetal e dos seus componentes envolvendo alguns ou todos os elementos (A). Canal para cálcio ( B). Canal de sódio, (C). Proteína transportadora e receptora de membrana de solutos (por exemplo, ferro), (D). Proteína de ligação do cálcio (E). Permutador de $\mathrm{Na} / \mathrm{Ca}^{2+}(\mathrm{F})$. Encadernação moléculas supostamente envolvidos no movimento através sinciotrofoblasto (proteínas transportadora), (G). Interconversão interplacental metabólica ou catabolismo, (H). Via de transferência de água e íons ( $\mathrm{Ca}$ e $\mathrm{Cl}$ ). I. Mecanismos de transporte na membrana basal sincicial

Figura 2 - Mecanismos de transferência através da microvilosidades do sinciotrofoblasto (a) difusão simples (b) canais de íons (por exemplo, $\mathrm{Cl}^{-}, \mathrm{Ca}$ ) (c) Difusão facilitada (d) Endocitose mediada por receptor ligado ao soluto (por exemplo, ferro, IGG) (e) aquaporina (por exemplo, transporte de água) (f) Co-transporte (alanina e sódio) (g) Transporte impulsionado ativo, ATP-ADP (por exemplo, $\mathrm{Na}+$ troca por $2 \mathrm{~K})(\mathrm{h})$ Receptor de endocitose mediada. $\Delta \mathrm{C}$, as diferenças de concentração; $\Delta \Pi$, diferenças de pressão osmótica, $\Delta \mathrm{P}$, diferenças de pressão hidrostática; $\Delta \Psi$, diferença de potencial elétrico, todos expressos em todo o microvilosidades da membrana

Figura 3 - Placenta bovina com 90 dias de gestação carúnculas e cotilédones apresentam identificadas na imagem. Barra 2,5 cm

Figura 5 - Útero gravídico A) Corno não gestante B) Corno gestante. Barra: $20 \mathrm{~cm}$. .50

Figura 6 - Corno gestante aberto exposição de feto e placenta. 1) de a - b medida "Crow Rump" do feto, c) placenta bovina, fileiras de placentônios, 2) placentônios. Barra (1) $20 \mathrm{~cm}$ (2) $2,5 \mathrm{~cm}$

Figura 7 - Placentônios bovinos e região inter placentomal (IPL), a) MiPL Microplacentônio $(0,90 \mathrm{~cm})$, b) PLC - Parte central do placentônio, c) PLM Parte das margens do placentônio. Barra: $10 \mathrm{~cm}$

Figura 8 - Esquema de corte placentônio para separação das regiões distintas, na qual PLC a região central, PLM - região marginal, IPL - região entre os placentônios

Figura 9 - A) Criostato Leica CM 1850, B) Vista do micrótomo, C) Vista do Bloco Térmico do micrótomo (a) amostra fixada no disco, posicionado no bloco térmico.

Figure 10 - A) Liofilizador Terroni LC 1500, B) Torre de liofilização à vácuo .55

Figura 11 - (1) Pastilhador: a) base de apoio da amostra, b) base que fica sobre a amostra em pó, c) base de compressão para a prensa, (2) Pastilhas 
Figura 12 - Absorção fotoelétrica. (a) Fóton com energia E interage com o átomo. (b) A energia $\mathrm{E}$ do fóton incidente á absorvida pelo elétron da camada $\mathrm{K}$ e o elétron é ejetado da camada $\mathrm{L}$ como um fotoelétron, com energia cinética $\mathrm{E}^{\mathrm{fe}}(\mathrm{c})$ ocorre a emissão de um fóton.

Figura 13- Exemplo de espectro EDXRF das amostras.

Figura 14 - Vista Geral do anel de armazenamento e da estação experimental D09B-XRF do Laboratório de Luz Síncrotron com a instrumentação ....

Figura 15 - Arranjo experimental da microfluorência de raios X, (1) colimador (2) capilar (3) detector (4) porta amostra

Figura 16 - Posicionamento da amostra para medida (A) Porta amostra lacrado com papel filme, (B) Vista do interior do porta amostra, (C) partes individuais do porta amostra

Figura 17 - (A) Espectrômetro de fluorescência de raios $\mathrm{X}$ por dispersão de energia (EDXRF), (B)Frascos de polietileno com amostra em pó, (C) Suporte para os porta amostra para análise

Figura 18 - Diagrama em caixa (boxplot) da concentração de sódio (\%) para a região IPL para todos os grupos e períodos gestacionais

Figura 19 - Diagrama em caixa (boxplot) da concentração de sódio (\%) para a região PLM para todos os grupos e períodos gestacionais....

Figura 20 - Diagrama em caixa (boxplot) da concentração de magnésio $\left(\mu \mathrm{g} \mathrm{g}^{-1}\right)$ para a região IPL para todos os grupos e períodos gestacionais..... 71

Figura 21 - Diagrama em caixa (boxplot) da concentração de magnésio $\left(\mu \mathrm{g} \mathrm{g}^{-1}\right)$ para a região PLM para todos os grupos e períodos gestacionais.

Figura 22 - Diagrama em caixa (boxplot) da concentração de fósforo (\%) para a região IPL para todos os grupos e períodos gestacionais....

Figura 23 - Diagrama em caixa (boxplot) da concentração de fósforo (\%) para a região PLC para todos os grupos e períodos gestacionais.

Figura 24 - Diagrama em caixa (boxplot) da concentração de fósforo (\%) para a região PLM para todos os grupos e períodos gestacionais

Figura 25 - Diagrama em caixa (boxplot) da concentração de cloro (\%) para a região IPL para todos os grupos e períodos gestacionais.

Figura 26 - Diagrama em caixa (boxplot) da concentração valores de cloro (\%) para a região PLC para todos os grupos e períodos gestacionais. 
Figura 27 - Diagrama em caixa (boxplot) da concentração de cloro (\%) para a região PLM para todos os grupos e períodos gestacionais.

Figura 28 - Diagrama em caixa (boxplot) da concentração valores de potássio (\%) para a região IPL para todos os grupos e períodos gestacionais .80

Figura 29 - Diagrama em caixa (boxplot) da concentração de potássio (\%) para a região PLC para todos os grupos e períodos gestacionais

Figura 30 - Diagrama em caixa (boxplot) da concentração de potássio (\%) para a região PLM para todos os grupos e períodos gestacionais.

Figura 31 - Diagrama em caixa (boxplot) da concentração de cálcio $\left(\mu \mathrm{g} \mathrm{g}^{-1}\right)$ para a região IPL para todos os grupos e períodos gestacionais.

Figura 32 - Diagrama em caixa (boxplot) da concentração de cálcio $\left(\mu \mathrm{g} \mathrm{g}^{-1}\right)$ para a região PLC para todos os grupos e períodos gestacionais

Figura 33 - Diagrama em caixa (boxplot) da concentração de cálcio $\left(\mu \mathrm{g} \mathrm{g}^{-1}\right)$ para a região PLM para todos os grupos e períodos gestacionais.

Figura 34 -Diagrama em caixa (boxplot) da concentração de manganês $\left(\mu \mathrm{g} \mathrm{g}^{-1}\right)$ para a região IPL para todos os grupos e períodos gestacionais.....

igura 35 - Diagrama em caixa (boxplot) da concentração de manganês $\left(\mu \mathrm{g} \mathrm{g}^{-1}\right)$ para a região PLC para todos os grupos e períodos gestacionais.

Figura 36 - Diagrama em caixa (boxplot) da concentração de manganês $\left(\mu \mathrm{g} \mathrm{g}^{-1}\right)$ para a região PLM para todos os grupos e períodos gestacionais.

Figura 37 - Diagrama em caixa (boxplot) da concentração de ferro $\left(\mu \mathrm{g} \mathrm{g}^{-1}\right)$ para a região IPL para todos os grupos e períodos gestacionais.

Figura 38 - Diagrama em caixa (boxplot) da concentração de ferro $\left(\mu \mathrm{g} \mathrm{g}^{-1}\right)$ para a região IPL para todos os grupos e períodos gestacionais....

Figura 39 - Diagrama em caixa (boxplot) da concentração de ferro $\left(\mu \mathrm{g} \mathrm{g}^{-1}\right)$ para a região PLM para todos os grupos e períodos gestacionais.

Figura 40 - Diagrama em caixa (boxplot) da concentração valores de cobre $\left(\mu \mathrm{g} \mathrm{g}^{-1}\right)$ para a região PLC para todos os grupos e períodos gestacionais....

Figura 41 - Diagrama em caixa (boxplot) da concentração valores de cobre ( $\left.\mu \mathrm{g} \mathrm{g}^{-1}\right)$ para a região PLM para todos os grupos e períodos gestacionais.

Figura 42 - Diagrama em caixa (boxplot) da concentração valores de zinco $\left(\mu \mathrm{g} \mathrm{g}^{-1}\right)$ para a região IPL para todos os grupos e períodos gestacionais 
Figura 43- Diagrama em caixa (boxplot) da concentração valores de zinco $\left(\mu \mathrm{g} \mathrm{g}^{-1}\right)$ para a região PLC para todos os grupos e períodos gestacionais.

igura 44 - Diagrama em caixa (boxplot) da concentração valores de zinco $\left(\mu \mathrm{g} \mathrm{g}^{-1}\right)$ para a região PLM para todos os grupos e períodos gestacionais

Figura 45 - Esquema ilustrativo da amostra de placenta bovina apresenta-se detalhe da área mapeada circulada em vermelho. Barra: $1 \mathrm{~cm}$.

Figura 46 - Exemplos de perfis adquiridos para uma amostra de placentônio bovino .101

Figura 47 - (A) Fotomicrografia de placentônio bovino GCO 90 dias de gestação *vermelho (epitélio materno) e *amarelo (epitélio fetal). Mapeamento bidimensional da concentração elementar em amostra de placentônio por $\mu \mathrm{XRF}$. Barra $500 \mu \mathrm{m}$.

Figura 48 - (A) Fotomicrografia de placentônio bovino GCL com 90 dias de gestação, *vermelho (epitélio materno) e *amarelo (epitélio fetal). (B) Mapeamento bidimensional da concentração elementar em amostra de placentônio por $\mu \mathrm{XRF}$. Barra: (A) $500 \mu \mathrm{m}, 200 \mu \mathrm{m}$

Figura 49 - (A) Fotomicrografia de placentônio bovino GCO 135 dias de gestação, *vermelho (epitélio materno) e *preto (epitélio fetal). (B) Mapeamento bidimensional da concentração elementar em amostra de placentônio por $\mu \mathrm{XRF}$. Barra: $500 \mu \mathrm{m}$

Figura 50 - (A) Fotomicrografia de placentônio bovino GCL 135 dias de gestação, *vermelho (epitélio materno) e *preto (epitélio fetal). (B) Mapeamento bidimensional da concentração elementar em amostra de placentônio por $\mu$ XRF. Barra $500 \mu \mathrm{m}$

Figura 51 - (A) Fotomicrografia de placentônio bovino GCO com 225 dias de gestação, *vermelho (epitélio materno) e *preto (epitélio fetal). (B) Mapeamento bidimensional da concentração elementar em amostra de placentônio por $\mu \mathrm{XRF}$. Barra: $500 \mu \mathrm{m}, 200 \mu \mathrm{m}$ 106

Figura 52 - (A) Fotomicrografia de placentônio bovino GCO com 225 dias de gestação, *vermelho (epitélio materno) e *preto (epitélio fetal). (B) Mapeamento bidimensional da concentração elementar em amostra de placentônio por $\mu \mathrm{XRF}$. Barra: $500 \mu \mathrm{m}, 200 \mu \mathrm{m}$ 107

Figura 53 - (A) Fotomicrografia de placentônio bovino GCO com 225 dias de gestação, seta preta (vasos sangüíneos). (B) Mapeamento bidimensional da concentração elementar em amostra de placentônio por $\mu \mathrm{XRF}$. Barra: $500 \mu \mathrm{m}, 200 \mu \mathrm{m}$

Figura 54 - (A e B) Fotomicrografia da região interplacentomal de bovino GCL 90 dias de gestação, seta preta (glândulas endometriais) e seta vermelha (vaso sanguíneo). (C) Mapeamento bidimensional da concentração em amostra de placentônio. Barra (A) $500 \mu \mathrm{m}$, (B) $200 \mu \mathrm{m}$ 
Figura 55- (A) Fotomicrografia da região interplacentomal de bovino GCL 135 dias de gestação e seta preta (glândulas endometriais). (B) Imagem adquirida de amostra de placentônio liofilizada no momento da aquisição dos dados de $\mu \mathrm{XRF}$. (C) Mapeamento bidimensional da concentração elementares .Barra (A) $500 \mu \mathrm{m}$, (B) $0,5 \mathrm{~mm}$.

Figura 56- (A) Fotomicrografia da região interplacentomal de bovino GCL 225 dias de gestação, seta fibras musculares do miométrio do epitélio uterino. (B) Mapeamento bidimensional da concentração elementar em amostra de placentônio por $\mu$ XRF. Barra: $500 \mu \mathrm{m}$

Figura 57 - (A) microplacentônio liofilizado, (B) histologia de microplacentônio. Barra: (A) $1,5 \mathrm{~cm}$, (B) $200 \mu \mathrm{m}$

Figura 58 - (A) Imagem de microplacentônio região caruncular de placenta bovina. (B) Mapeamento bidimensional da distribuição elementar em amostra de placentônio $\mu$ XRF. Barra: $1 \mathrm{~cm}$

Figure 59 - Imagem da região central da carúncula de placenta bovina que foi mapeada sinalizada em vermelho. Mapeamento bidimensional da distribuição elementar em amostra de placentônio por $\mu$ XRF. Barra: (A) $1,5 \mathrm{~cm}$ (B) $0,1 \mathrm{~mm}$.

Figure 60 - Imagem da região marginal da carúncula de placenta bovina que foi mapeada sinalizada em vermelho. Mapeamento bidimensional da distribuição elementar em amostra de placentônio por $\mu$ XRF. Barra: (A) $1,5 \mathrm{~cm}$, (B) $0,1 \mathrm{~mm}$.

Figura 61 - (A) Imagem vilos cotiledonares de placenta bovina. (B) Mapeamento bidimensional da distribuição elementar em amostra de placentônio por $\mu \mathrm{XRF}$. Barra: $0,5 \mathrm{~mm}$.

Figura 62- (A) Imagem vilos cotiledonares de placenta bovina. (B) Mapeamento bidimensional da distribuição elementar em amostra de placentônio por $\mu \mathrm{XRF}$. Barra: $0,5 \mathrm{~mm}$.

Figure 63 - (A) Imagem vilos cotiledonares de placenta bovina. (B) Mapeamento bidimensional da distribuição elementar em amostra de placentônio por $\mu \mathrm{XRF}$. Barra: $0,5 \mathrm{~mm}$.

Figure 64 - (A) Imagem da região interplacentomal de placenta bovina região que foi mapeada sinalizada em vermelho. (B) Mapeamento bidimensional da distribuição elementar em amostra de placentônio por $\mu \mathrm{XRF}$. Barra: (A) $1 \mathrm{~cm}$, (B) $0,5 \mathrm{~mm}$

Figure 65 - Imagem da região interplacentomal de placenta bovina. Mapeamento bidimensional da distribuição elementar em amostra de placentônio por $\mu$ XRF. Barra: $0,5 \mathrm{~mm}$. 
Figure 66 - Imagem dos vasos sanguíneos da região sobre o placentônio. Mapeamento bidimensional da distribuição elementar em amostra de placentônio por $\mu$ XRF. Barra: $0,5 \mathrm{~mm}$.

Figura 67 - Figura que ilustra as relações de antagonismo e sinergismo dos minerais iônicos .133 


\section{LISTA DE TABELA}

Tabela 1 - Concentração elementar $\left(\mu \mathrm{g} \mathrm{g}^{-1}\right)$ para o material de referência fígado bovino 1577b, Instituto de Pesquisas Energéticas e Nucleares (IPEN), São Paulo, 2009 a 2010 .

Tabela 2 - Concentração elementar (\%) para o material de referência fígado bovino 1577b, Instituto de Pesquisas Energéticas e Nucleares (IPEN), São Paulo, 2009 a 2010

Tabela 3 - Valores de sódio (Na) para GCO e GCL para as regiões PLC, PLM e IPL Formação dos grupos segundo o teste de Tukey HSD (ANOVA, $\alpha<0.05$ ); ns: não significativo $(\alpha>0.05)$. Valor do teste t para GCO e GCL, localizados na mesma região do placentônio e mesmo período gestacional $(90,135$ ou 225 dias), Instituto de Pesquisas Energéticas e Nucleares (IPEN), São Paulo, 2009 a 2010

Tabela 4 - Valores de magnésio (Mg) para GCO e GCL para as regiões PLC, PLM e IPL Formação dos grupos segundo o teste de Tukey HSD (ANOVA, $\alpha<0.05$ ); ns: não significativo $(\alpha>0.05)$. Valor do teste $t$ para GCO e GCL, localizados na mesma região do placentônio e mesmo período gestacional (90, 135 ou 225 dias), Instituto de Pesquisas Energéticas e Nucleares (IPEN), São Paulo, 2009 a 2010

Tabela 5 - Valores de fósforo (P) para GCO e GCL para as regiões PLC, PLM e IPL Formação dos grupos segundo o teste de Tukey HSD (ANOVA, $\alpha<0.05$ ); ns: não significativo $(\alpha>0.05)$. Valor do teste $t$ para GCO e GCL, localizados na mesma região do placentônio e mesmo período gestacional $(90,135$ ou 225 dias), Instituto de Pesquisas Energéticas e Nucleares (IPEN), São Paulo, 20092010

Tabela 6 - Valores de cloro $(\mathrm{Cl})$ para GCO e GCL para as regiões PLC, PLM e IPL Formação dos grupos segundo o teste de Tukey HSD (ANOVA, $\alpha<0.05$ ); ns: não significativo $(\alpha>0.05)$. Valor do teste $t$ para GCO e GCL, localizados na mesma região do placentônio e mesmo período gestacional $(90,135$ ou 225 dias) Instituto de Pesquisas Energéticas e Nucleares (IPEN), São Paulo, 20092010

Tabela 7 - Valores de Potássio (K) para GCO e GCL para as regiões PLC, PLM e IPL Formação dos grupos segundo o teste de Tukey HSD (ANOVA, $\alpha<0.05$ ); ns: não significativo $(\alpha>0.05)$. Valor do teste t para GCO e GCL, localizados na mesma região do placentônio e mesmo período gestacional $(90,135$ ou 225 dias), Instituto de Pesquisas Energéticas e Nucleares (IPEN), São Paulo, 20092010 
Tabela 8 - Valores de cálcio $(\mathrm{Ca})$ para GCO e GCL para as regiões PLC, PLM e IPL Formação dos grupos segundo o teste de Tukey HSD (ANOVA, $\alpha<0.05$ ); ns: não significativo $(\alpha>0.05)$. Valor do teste t para GCO e GCL, localizados na mesma região do placentônio e mesmo período gestacional $(90,135$ ou 225 dias), Instituto de Pesquisas Energéticas e Nucleares (IPEN), São Paulo, 20092010

Tabela 9 - Valores de manganês (Mn) para GCO e GCL para as regiões PLC, PLM e IPL Formação dos grupos segundo o teste de Tukey HSD (ANOVA, $\alpha<0.05$ ); ns: não significativo $(\alpha>0.05)$. Valor do teste t para GCO e GCL, localizados na mesma região do placentônio e mesmo período gestacional $(90,135$ ou 225 dias), Instituto de Pesquisas Energéticas e Nucleares (IPEN), São Paulo, 20092010

Tabela 10 - Valores de ferro (Fe) para GCO e GCL para as regiões PLC, PLM e IPL Formação dos grupos segundo o teste de Tukey HSD (ANOVA, $\alpha<0.05$ ); ns: não significativo $(\alpha>0.05)$. Valor do teste t para GCO e GCL, localizados na mesma região do placentônio e mesmo período gestacional $(90,135$ ou 225 dias), Instituto de Pesquisas Energéticas e Nucleares (IPEN), São Paulo, 20092010

Tabela 11 - Valores de cobre $(\mathrm{Cu})$ para GCO e GCL para as regiões PLC, PLM e IPL Formação dos grupos segundo o teste de Tukey HSD (ANOVA, $\alpha<0.05$ ); ns: não significativo $(\alpha>0.05)$. Valor do teste t para GCO e GCL, localizados na mesma região do placentônio e mesmo período gestacional $(90,135$ ou 225 dias), Instituto de Pesquisas Energéticas e Nucleares (IPEN), São Paulo, 20092010 .

Tabela 12 - Valores de zinco (Zn) para GCO e GCL para as regiões PLC, PLM e IPL Formação dos grupos segundo o teste de Tukey HSD (ANOVA, $\alpha<0.05$ ); ns: não significativo $(\alpha>0.05)$. Valor do teste t para GCO e GCL, localizados na mesma região do placentônio e mesmo período gestacional $(90,135$ ou 225 dias), Instituto de Pesquisas Energéticas e Nucleares (IPEN), São Paulo, 20092010

Tabela 13 -A interelação entre os minerais, nas diferentes regiões da placenta de bovino clonado, quando apresentado alterações na concentração quando comparada ao GCO Instituto de Pesquisas Energéticas e Nucleares (IPEN), São Paulo, 20092010 


\section{SUMÁRIO}

INTRODUÇÃO .24

OBJETIVOS GERAIS. .27

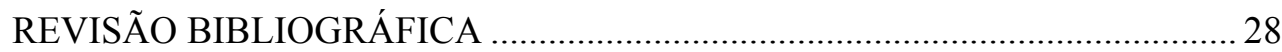

BOVINOCULTURA NO CONTEXTO NACIONAL …........................................ 28

ELEMENTOS TRAÇO NO DESENVOLVIMENTO EMBRIONÁRIO ................35

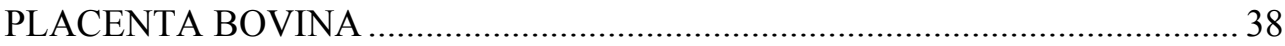

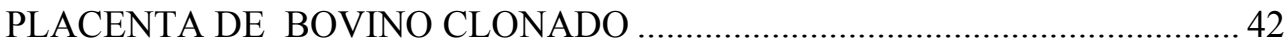

FUNDAMENTAÇÃO TEÓRICA FLUORESCÊNCIA DE RAIOS X …............... 43

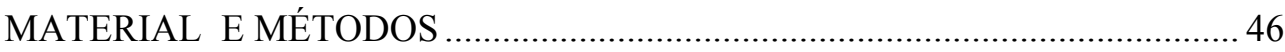

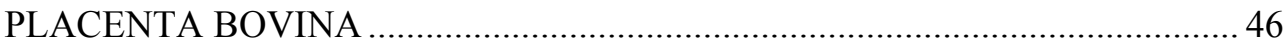

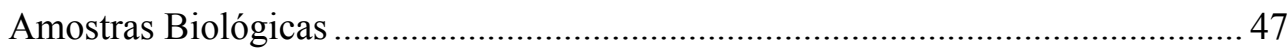

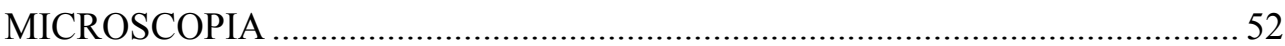

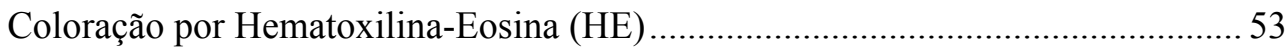

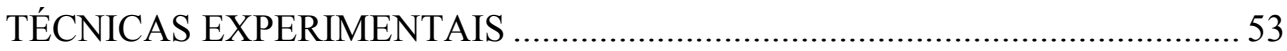

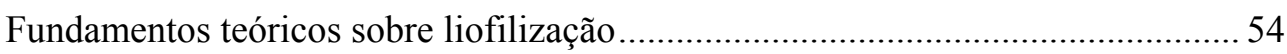

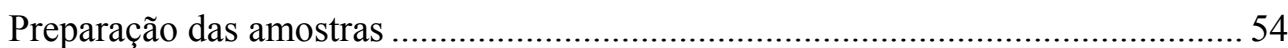

FUNDAMENTOS TEÓRICOS SOBRE FLUORESCÊNCIA DE

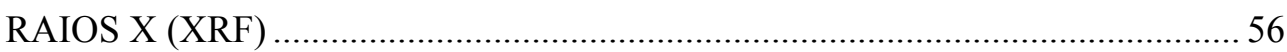

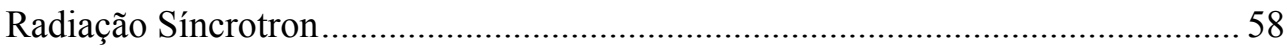

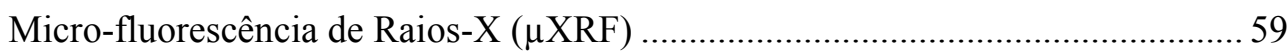

FUNDAMENTOS TEÓRICOS SOBRE FLUORESCÊNCIA DE RAIOS X POR DISPERSÃO DE ENERGIA (EDXRF)........................................ 62

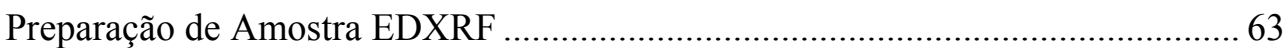

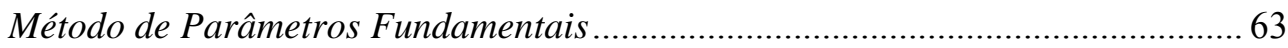

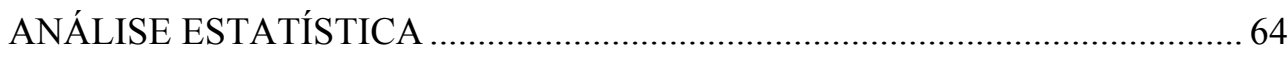

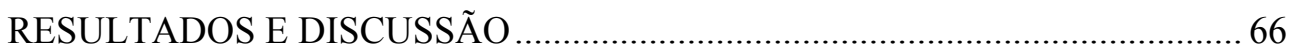

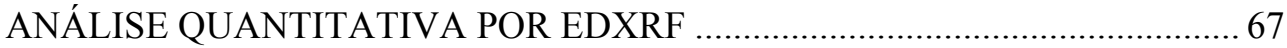




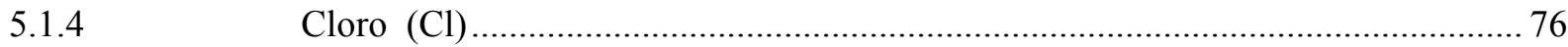

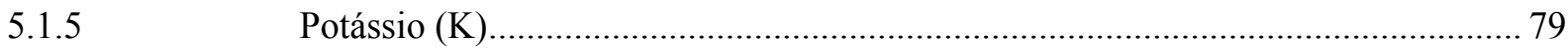

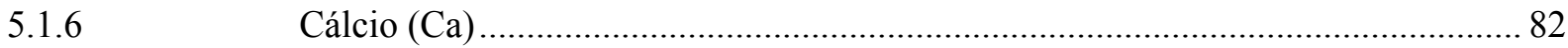

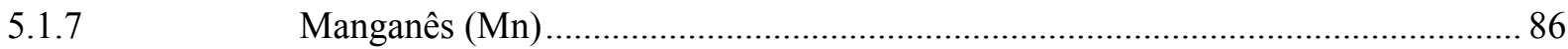

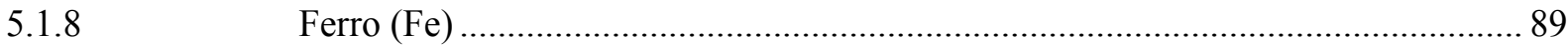

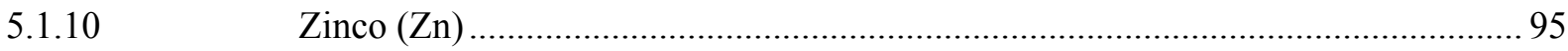

5.2 MAPAS BIDIMENSIONAIS DA CONCENTRAÇÃO ELEMENTAR EM PLACENTA DE BOVINO $\mu$ XRF .......................................................... 100

5.3 MAPAS DE DISTRIBUIÇÃO Einterelação ELEMENTAR, $\mu$ XRF …................. 121

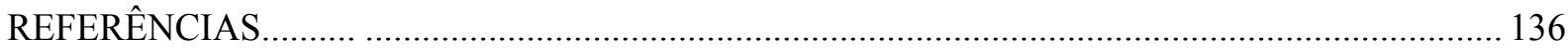

ANEXO A

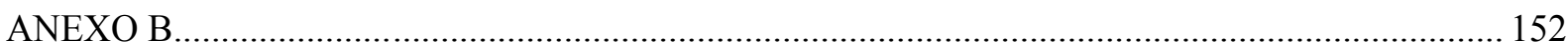




\section{INTRODUÇÃO}

Em linhas gerais essa dissertação fundamenta-se na necessidade contínua e da profícua descrição das bases científicas da Pecuária Brasileira frente ao panorama de agregação de conhecimentos em que essa grande área está inserida. Tendo como premissa básica contextualizar a bovinocultura de corte no país e seqüencialmente abordar aspectos importantes e sistematizados para a definição do papel dos elementos químicos e suas respectivas concentrações nos tecidos placentários e propor questionamentos sobre deficiência, suplementação, manutenção das funções e caracterização dos tecidos placentários num cenário cuja ênfase dada nessa dissertação constitui-se como pioneira por incorporar técnicas modernas à dinâmica existente de investigação científica.

A deficiência mineral é um problema característico da maioria dos sistemas de produção nas diversas partes do mundo, gerando perdas econômicas em virtude da diminuição da produtividade do rebanho.

Os bovinos são caracterizados como fonte de alimentação animal para o homem e de alta demanda, o equilíbrio mineral adequado garante ao animal boa qualidade de vida. Geralmente e desequilíbrio minerais estão relacionados com a quebra da homeostasia dos elementos no organismo pelo aumento no organismo da demanda orgânica no desafio metabólico da produção (ganho de peso, gestação, lactação e estresse) A conseqüência elevada das exigências nutricionais e a diminuição da disponibilidade dos elementos, na alimentação são fatores desencadeantes de distúrbios (BARCELLOS, PRATES, OSPINA, 1999). Desse modo, pesquisas científicas que visem a avaliação de aspectos que possam interferir direta ou indiretamente na produtividade dos rebanhos e ou qualidade de vida desses animais são imprescindíveis. Mesmo que de forma indireta, todos os minerais e vitaminas têm alguma relação com as funções reprodutivas em bovinos.

Em grande parte do mundo, grandes quantidades de animais de fazenda consomem dietas que não correspondem as suas necessidades em relação aos minerais. Os alimentos podem ser ricos ou pobres em determinados elementos, o excesso de alguns minerais pode dificultar a absorção ou interagir no metabolismo de outros. Mesmo que uma dieta equilibrada contenha quantidades adequadas de um nutriente, alguns fatores endógenos podem contribuir para este desequilíbrio como, por exemplo, o estresse. A absorção ou transferência desses elementos nos mecanismos bioquímicos celulares são influenciado por diversos fatores físicos e biológicos. 
O nascimento de um animal saudável depende do desenvolvimento normal da placenta, que é um órgão vital para o desenvolvimento e crescimento fetal. Uma placenta desordenada é responsável por uma série de complicações na gravidez, que vão: desde a morte (aborto do embrião); a restrição do crescimento ou descolamento (prematuro da placenta) a deficiência do transporte de nutrientes ou oxigênio ao feto. Uma grande parte da mortalidade embrionária ocorre em fêmeas sadias em decorrência de uma comunicação materna embrionária deficiente, que impede a manutenção da gestação (BERGER, 2004).

O alto índice de mortalidade embrionária e fetal ocorre no terço inicial da gestação e corresponde uma das maiores causas de perdas econômicas na produção animal.

A clonagem animal representa sem dúvida um dos maiores avanços da biotecnologia animal. A baixa eficiência do processo de clonagem animal envolve problemas que podem estar associados aos fatores que promovem o crescimento placentário e vascular e suas interações materno-fetais.

A importância do estudo relativo ao mecanismo e função da placenta tem como fundamento fornecer ferramentas para a manutenção de uma gestação de conceptos saudáveis, visto que a placenta influencia na homeostase materna.

Pesquisas sobre possíveis fatores de risco para o desempenho reprodutivo de bovinos ainda são escassas justificando e indicando a necessidade de obter informações quantitativas nesta área (JOHNSTON, 2005; PEIXOTO, 2005).

Neste trabalho informamos sobre os elementos constituintes e traço, cujas concentrações foram determinadas por espectrometria de raios X, para grupos de animais não manipulados e clonados permitiram inferir sobre o papel dos elementos químico em fases gestacionais para regiões do tecido placentário.

Analisou-se animais em três períodos gestacionais distintos (90, 135 e 225 dias) em regiões da placenta por Microfluorescencia de raios $X(\mu \mathrm{XRF})$, obtendo-se o mapeamento bidimensional. Nesta etapa obtiveram-se mapas bidimensionais da concentração elementar de uma secção placentomal (especificamente placentônio e região interplacentomal) de bovino clonado, através da $\mu \mathrm{XRF}$, sendo realizada uma análise pontual destas mesmas regiões.

A avaliação da concentração elementar, em placenta bovina, em função do período gestacional para regiões envolvidas no transporte de nutrientes pela placenta, por Fluorescência de Raios X por dispersão de energia ED-XRF (Fluorescência de raios X por 
energia dispersiva) ambas as técnicas forneceram informações relevantes e seus resultados foram correlacionados.

Análise das variações da concentração elementar em relação a presença em maior ou menor escala ou a ausência de um elemento da amostra ou a associação interelementar. 


\section{OBJETIVOS GERAIS}

O principal objetivo desta dissertação baseou-se na determinação de elementos constituintes e traço e a quantificação de sua concentração. Estas análises permitirão compreender na compreensão aspectos anatômicos da placenta e interações físiológicas entre o feto e o ambiente materno.

- Avaliar a concentração de elementos traço em amostras de placentônios bovinos controle e clonados;

- Explorar hipóteses de interelações entre os elementos constituintes e traço;

- Determinar a variação na composição para os períodos gestacionais em animais não manipulados;

- Analisar respectivos mapas de distribuição nos placentônios bovinos de placenta oriunda de bovino clonado;

- Desenvolver uma metodologia eficiente com a técnica de Fluorescência de raios X para identificar as modificações químicas no tecido placentário. 


\section{REVISÃO BIBLIOGRÁFICA}

\subsection{BOVINOCULTURA NO CONTEXTO NACIONAL}

A bovinocultura de corte é desenvolvida em grande parte do território brasileiro. Estimativas mostram que a pecuária brasileira ocupa em média 172.333.073 hectares de pastagens naturais e plantadas (em boas condições e degradadas) com 2.650 .596 estabelecimentos pecuários (IBGE, 2006). O Brasil possui o segundo maior rebanho mundial de bovinos, ficando atrás somente da Índia, no entanto ocupa lugar de destaque no cenário internacional do mercado da carne, sendo o maior exportador. De acordo com os dados do IBGE (2006) o rebanho nacional chegou a 205.886.244 cabeças em 2006, e o estado do Paraná contribui com 9.764.545 cabeças, possuindo o segundo maior rebanho da Região Sul, ficando atrás do Rio Grande do Sul (13.974.827 cabeças).

Pedreira e Mello (2000) relatam que os sistemas pecuários brasileiros são caracterizados fundamentalmente pela utilização de pastagens como fonte principal de alimento para o rebanho. Segundo Euclides e Medeiros (2005), na pecuária, as pastagens assumem dois aspectos importantes: viabilizam a competitividade brasileira e possibilitam a produção de forma natural, com respeito ao ambiente e aos animais, atendendo grande parte da demanda mundial por alimento.

Diversas pastagens no Brasil, principalmente no Centro-Sul, apresentam deficiência em fósforo, zinco, cobre, cobalto, iodo, sódio, selênio (NICODEMO, 2008, FRANCIS, 2001). Com base nas funções gerais dos minerais, qualquer desequilíbrio mineral pode causar alterações no metabolismo animal, principalmente no seu desempenho reprodutivo, pois minerais com zinco, cobre, potássio estão diretamente envolvidos nestes processo (EMBRAPA, 2009). 


\subsection{ELEMENTOS TRAÇO PARA REPRODUÇÃO BOVINA}

A reprodução é provavelmente o mais importante parâmetro na produção animal. A maior parte dos problemas reprodutivos de bovinos deve-se ao consumo insuficiente de energia e de proteína (SIMMS et al., 1993).

As exigências de minerais em bovino variam de acordo com o tipo e nível de produção, a idade do animal, a raça e o graus de adaptação dos animais, a concentração e a forma química do mineral no alimento, e suas relações com os outros nutrientes da dieta (MCDOWELL, 1999).

As carências minerais estão entre os fatores que mais contribuem para a baixa produtividade de rebanho, corresponde um problema característico da maioria dos sistemas de produção nas diversas partes do mundo, gerando perdas econômicas em razão da diminuição da produtividade do rebanho. Todos os seres vivos necessitam de minerais para o funcionamento normal dos processos metabólicos.

Segundo Mcdowell (1992), os minerais podem ser classificados em macrominerais cálcio $(\mathrm{Ca})$, fósforo $(\mathrm{P})$, potássio $(\mathrm{K})$, sódio $(\mathrm{Na})$, cloro $(\mathrm{Cl})$, magnésio $(\mathrm{Mg})$ e enxofre $(\mathrm{S})$, quando são exigidos em quantidades relativamente grandes pelo organismo (gramas) e; elementos traço ou microminerais - cobalto $(\mathrm{Co})$, cobre $(\mathrm{Cu})$, iodo $(\mathrm{I})$, ferro $(\mathrm{Fe})$, manganês $(\mathrm{Mn})$, molibdênio (Mo), selênio (Se), flúor $(\mathrm{F})$ e zinco $(\mathrm{Zn})$, quando são exigidos em quantidades muito pequenas. Ainda de acordo com Poulsen (2005) e o National Council Research (NRC 2001) há outros elementos traço descobertos desde 1970 - arsênico (As), boro $(\mathrm{Br})$, chumbo $(\mathrm{Pb})$, lítio $(\mathrm{Li})$, níquel $(\mathrm{Ni})$, silício $(\mathrm{Si})$, estanho $(\mathrm{Sn})$ e vanádio $(\mathrm{V})$ que são essenciais para algumas espécies, mas ainda não há consenso na determinação das exigências nutricionais com as espécies domésticas com interesse produtivo.

Os macrominerais e os elementos traço compõem em torno de $3,5 \%$ do peso vivo do animal, não sendo uniforme a distribuição dos minerais dentro dos tecidos corporais, uma vez que diferentes tecidos precisam de concentrações distintas de elementos específicos. Os elementos traço compõem apenas $0,3 \%$ do peso vivo do animal (OLIVEIRA, 2007).

Os minerais são classificados em três categorias quanto aos níveis de concentração presentes em uma determinada amostra como: elementos ultra-traço $\left(0,01 \mu \mathrm{g} \mathrm{g}^{-1}\right)$, traço $(0,01$ $\left.-100 \mu \mathrm{g} \mathrm{g}^{-1}\right)$ e majoritários (> $\left.100 \mu \mathrm{g} \mathrm{g}^{-1}\right)(\mathrm{LINDH}, 1991)$. 
Um elemento traço é considerado essencial se sua deficiência resulta em um comprometimento da função fisiológica importante, ou se a sua retirada do corpo induz alterações fisiológicas, ou quando o elemento é uma parte integral de uma estrutura orgânica que desempenha uma função vital naquele organismo, independente da espécie (UNDERWOOD, 1981; LITTER, 1984; OMS, 1998). Estas alterações são acompanhadas por mudanças bioquímicas especificas, que podem ser evitadas ou recuperadas, corrigindose a deficiência. Há quinze minerais considerados essenciais na alimentação de mamíferos, arsênio, crômio, cobalto, cobre, flúor, iodo, ferro, manganês, molibdênio, níquel, selênio, silício, estanho, vanádio e zinco (ULLREY et al., 1977).

Estes são classificados de acordo com sua função biológica apresentando quatro funções básicas no organismo: Estrutural: os minerais como o $\mathrm{Ca}, \mathrm{P}, \mathrm{Mg}$ e F, exercem estas funções no tecido ósseo, o P e S como componente de proteínas musculares, também exercem funções estruturais. Fisiológica: a presença do $\mathrm{Na}, \mathrm{K}, \mathrm{Ca}$ e $\mathrm{Mg}$ nos tecidos líquidos corporais garantem o equilíbrio osmótico, o balanço ácido-básico e a permeabilidade das membranas, caracterizando as funções fisiológicas. Catalítica: os minerais podem atuar em atividades catalíticas de sistemas enzimáticos e hormonais como forma integral ou parcial em estruturas como metaloenzimas. Reguladora: minerais como $\mathrm{Ca}, \mathrm{Zn}$ e I têm sido encontrado em processos de regulação na replicação e diferenciação celular (UNDERWOOD; SUTTER, 1999).

Os elementos químicos são imprescindíveis na maioria dos processos metabólicos e fisiológicos no sistema biológico dos seres vivos (BOHIC et al., 2001). Estudos apontam que a deficiência ou o excesso nas concentrações $\mathrm{Ca}, \mathrm{Mn}, \mathrm{K}, \mathrm{Cl}$, Se podem induzir ao aparecimento de diversas desordens metabólicas (CUNNINGHAM, 2004). Alguns elementos como $\mathrm{Fe}, \mathrm{Cu}$ e $\mathrm{Zn}$ são considerados indicadores apropriados dos estados metabólicos das células (MAENHAUT et al., 1993). Todos eles são essenciais para a reprodução animal, em virtude de seu papel no metabolismo, na manutenção e desenvolvimento do sistema reprodutor (SIMMS et al., 1993; RIBEIRO, 1997; NICODEMO; SERENO; AMARAL , 2008).

Para o estudo na área de reprodução animal os elementos químicos são divididos em dois grupos distintos: um constituído pelos elementos necessários para o crescimento do tecido placentário; e o outro constituído por elementos responsáveis pelo crescimento fetal. Um feto requer grandes quantidades de elementos traço para um desenvolvimento normal. Eles participam de uma ou mais atividades enzimática, e desempenham diversas funções 
metabólicas conforme descrita de forma reduzida no quadro 1 (ENOMOTO; HIRUNUMA, 2001;CUNNIGHAM, 2004).

\begin{tabular}{|ll|}
\hline Minerais & Função \\
\hline Ferro (Fe) & $\begin{array}{l}\text { Transporte e armazenamento de oxigênio (hemoglobina, mioglobulina), transporte de } \\
\text { elétrons nas mitocôndrias, metabolismo das catecolaminas e síntese de DNA, } \\
\text { componentes de enzimas (catalase, triptofano 5-monoxigenase, fenilalanina 4- } \\
\text { monoxigenase, aconitase, heme-enzimas como os citocromos, peroxidases e enzimas } \\
\text { do grupo das metaloflavoproteínas, como a xantina oxidase e a enzima mitocondrial } \\
\text { alfa glicerofosfato oxidase) e síntese de neurotransmissores }\end{array}$ \\
Zinco (Zn) & $\begin{array}{l}\text { Presente em mais de 70 enzimas (álcool desidrogenase, carboxipeptidase, piruvato } \\
\text { desidrogenase), expressão gênica, estabilidade das membranas, diferenciação e } \\
\text { proliferação celular, manutenção do sistema imunológico, manutenção do revestimento }\end{array}$ \\
uterino para a implantação do embrião e regeneração dos revestimentos do útero após o \\
parto \\
Cobre (Cu) & $\begin{array}{l}\text { Componentes de diversas enzimas (lisil oxidase, tiroxidase, citocromo oxidase, } \\
\text { superóxido dismutase), desenvolvimento cerebral, prevenir a Ataxia neonatal } \\
\text { enzoótica }\end{array}$ \\
Iodo (I) & $\begin{array}{l}\text { Componentes dos hormônios tireoidianos, que participam na regulação do } \\
\text { metabolismo energético }\end{array}$ \\
Manganês (Mn) & $\begin{array}{l}\text { Componentes de enzimas (piruvato carboxidase, arginase, superóxido dismutase } \\
\text { mitocondrial), ativador enzimático (glicosil transferases) }\end{array}$ \\
Cobalto (Co) & Componentes da vitamina B ${ }_{12}$ \\
Molibdênio (Mo) & Componentes de enzimas (xantina oxidase, sulfito oxidase, aldeído oxidase) \\
Selênio (Se) & $\begin{array}{l}\text { Componentes de enzimas (glutationa peroxidase, iodotironina deidase tipo I), } \\
\text { manutenção sistema imunológico, antioxidante, associado com tiroxina ( hormônio da } \\
\text { tireóide), protege o organismo de metais pesados }\end{array}$ \\
&
\end{tabular}

Fontes: Lobão, 1976; Embrapa, 2009, Miller et al., 1993b, Khalili et al, 2008, Nix (2002), Alves, Arantes, Mudim, 2006; Cançado, Chiattone, 2009, Youdim et al, 1989, Bennetts e Chapman, 1937, Tufan et al , 2008, Cunningham, (2004)

Quadro 1 - Funções metabólicas mais importantes dos elementos traço essenciais para os animais domésticos. Adaptada de Spears (1998), São Paulo, agosto de 2009

A deficiência mineral é geralmente múltipla, isto é, de vários elementos ao mesmo tempo, e pode estar acompanhada por problemas infecciosos, especialmente nas deficiências dos microelementos zinco, cobre, ferro, selênio e iodo, que podem aumentar a susceptibilidade a infecções por estarem associados a diversas conseqüências patológicas (CUNNIGHAM, 2004 ; SUTTLE \& JONES, 1989; CHANDRA, 1997), no quadro 2 sumarizou-se as principais alterações. 


\begin{tabular}{|c|c|c|}
\hline Minerais & Autores & Deficiência \\
\hline Manganês (Mn) & $\begin{array}{l}\text { Lobão, } 1976 \\
\text { Embrapa, } 2009 \\
\text { Kavazis, Kavipleto, Ott, } 2002 .\end{array}$ & $\begin{array}{l}\text {-Redução do índice de fertilidade, atraso do cio, } \\
\text { abortos, nascimento de bezerros com aumento das } \\
\text { articulações, casco virado para trás } \\
\text {-O feto pode ter um crescimento ósseo, } \\
\text { cartilaginoso e endocondral limitado }\end{array}$ \\
\hline Iodo (I) & $\begin{array}{l}\text { Miller et al., 1993b } \\
\text { Corah e Ives, } 1991 \\
\text { Ferguson, } 1991 .\end{array}$ & $\begin{array}{l}\text {-Hipotireóidismo ou bócio } \\
\text {-Baixo desempenho reprodutivo, aumento na taxa } \\
\text { de mortalidade embrionária precoce, aborto, } \\
\text { animais fracos, aumento na incidência de retenção } \\
\text { de placenta, redução na taxa de concepção, perda de } \\
\text { pêlo e lã }\end{array}$ \\
\hline Zinco (Zn) & $\begin{array}{l}\text { Khalili et al., } 2008 \\
\text { Hidiroglou, } 1979 \\
\text { Nix, 2002, Novaes, } 2005 \\
\text { Silva et al., } 2007 \\
\text { Niles et al., } 2008\end{array}$ & $\begin{array}{l}\text {-Defeito na imunidade celular } \\
\text {-Paraqueratose hereditária } \\
\text {-Abortos, mumificação fetal, menor peso ao nascer } \\
\text { e partos prolongados, decréscimo na atividade das } \\
\text { células NK. Carência de vitamina A }\end{array}$ \\
\hline Selênio (Se) & $\begin{array}{l}\text { Nielsen, 2004; Amorim et al., 2005; } \\
\text { Hall et al., 2009,Abutarbush, } 2003 \\
\text { Alves, Arantes, Mudim, 2006; } \\
\text { Flemming, 2007; Cocato et al., } 2008\end{array}$ & $\begin{array}{l}\text {-Defeito na função neutrofílica } \\
\text {-Degeneração muscular conhecida como doença do } \\
\text { Músculo Branco } \\
\text {-Necrose hepática } \\
\text {-Miopatia: cardíaca e esquelética }\end{array}$ \\
\hline Ferro $(\mathrm{Fe})$ & $\begin{array}{l}\text { Paschoal, } 2008 \\
\text { Youdim, Bem-Shachard, Yehuda, } \\
1989 \\
\text { Umbelino, Rossi, 2006. Walter, } \\
\text { 2002. White, 1998, Keen et al., } \\
1998\end{array}$ & $\begin{array}{l}\text {-Anemia ferropriva } \\
\text {-Diminuição significativa da neurotransmissão } \\
\text { dopaminérgica resultante DAC, redução do número } \\
\text { de receptores } \mathrm{D}_{2} \text { dopamina } \\
\text {-Aumento dos níveis de leucócitos } \\
\text {-Estresse oxidativo } \\
\text {-Alteração o desenvolvimento embrionário ou fetal }\end{array}$ \\
\hline $\begin{array}{l}\text { Cobre } \\
(\mathrm{Cu})\end{array}$ & $\begin{array}{l}\text { Bennetts e Chapman, 1937 } \\
\text { Widdowson et al., 1974; Hostetler, } \\
\text { Kincaid, Mirando, 2003, Hawk, } \\
\text { 2003, Valle, Falchuk, 2003 } \\
\text { Fisher, 1990a, -Johnson, } 2005 \text {. } \\
\text { Campbell et al., 2001; Emerit, } \\
\text { Edeas, Bricaire, 2004; Sergeant, } \\
\text { Vesvres, Deves, 2005,Tufan et al., } \\
\text { 2008,Marques et al., 2003 } \\
\text { Fletcher, 2002, Keen et al., 1998, } \\
\text { Penland e Prohaska,2004, Bertolo, } \\
\text { Beltger, Atkinson, 2001. Bradley et } \\
\text { al., 1983, Gipp et al., 1974 }\end{array}$ & $\begin{array}{l}\text {-Ataxia neonatal enzoótica, aplasia mielínica. } \\
\text {-Crescimento deficiente } \\
\text {-Incidência de natimortos e mortalidade neonatal. } \\
\text {-Redução do citocromo mitocondrial } \\
\text {-Doenças neurodegenerativas. } \\
\text {-Alteração na produção de melanina } \\
\text {-Anemia } \\
\text {-Alteração desenvolvimento embrionário ou fetal. } \\
\text {-Alteração na queratinação, pêlos e lã }\end{array}$ \\
\hline
\end{tabular}

Quadro 2 - Principais alterações patológicas nas deficiências de elementos traço. Adaptada de CUNNINGHAM (2004), São Paulo, janeiro de 2010.

Ao contrário de outros nutrientes, os elementos traço não podem ser sintetizados pelos seres vivos. Eles atuam como: 1) componentes estruturais nos órgãos e tecidos corporais (por exemplo, o cálcio e o fósforo na formação do esqueleto, o fósforo que compõe as camadas das células); 2) constituintes dos líquidos corporais como eletrólitos (por 
exemplo, o ferro existente no sangue atuando no transporte de oxigênio, e, o cálcio e o potássio existentes no líquido que irriga o coração) e 3) como catalisadores (substâncias que podem modificar a velocidade de reações no organismo) nos sistemas enzimáticos e hormonais (OLIVEIRA, 2007).

A deficiência de elementos traço no rastreamento de animais é freqüentemente dividida em dois tipos de categorias: 1. Primária: a deficiência resultante do consumo de um elemento traço e não traço essencial em níveis insuficientes para suportar as funções fisiológicas associadas a esse elemento. 2. Secundária: uma deficiência resultante do consumo de um elemento que antagoniza ou pré ou pós-absorção de um elemento traço essencial tornando o elemento incapaz de suportar as funções fisiológicas associadas a este elemento.

Os animais possuem capacidade de acumular reservas de minerais e utilizá-las em períodos de restrição. Apesar da deficiência mineral na dieta, o animal pode permanecer em bom estado por alguns meses, dependendo da severidade da deficiência e de suas reservas. Minerais como $\mathrm{Cu}$, Se, $\mathrm{Ca}$ e $\mathrm{P}$ podem ficar armazenados por mais tempo, entretanto outros como $\mathrm{Zn}, \mathrm{Mn}, \mathrm{Na}$ e Mg não são armazenados em quantidades suficientes ou suas reservas não estão suficientemente disponíveis (NICODEMO, 1999).

Trabalhos recentes têm demonstrado que a resposta imune é reduzida em bovinos (WRIGHT; PETER e MACK, 1982) e ovinos (FISHER e MACPHERSON, 1986) em razão da deficiência de minerais.

O cálcio, magnésio, fósforo e sulfato são também íons importantes, considerados macronutrientes, todos são necessários a muitos processos fisiológicos. Qualquer grande alteração nas suas concentrações é deletéria ou fatal. Os íons de cálcio são necessários para a função normal da célula, condução nervosa, contração muscular e coagulação sanguínea. Se a concentração sanguínea de cálcio de um mamífero cair para aproximadamente a metade de seu valor normal, isso resultaria em câimbras tetânicas severas ou fatais. Sua absorção no corpo depende da presença de vitamina D, bem como de outros fatores, incluindo a utilização de ácidos digestivos que permitem a quebra para a absorção intestinal (SUTTER; JONES, 1989).

O excesso de cálcio pode prejudicar a função reprodutiva em virtude da deficiência secundária de $\mathrm{P}, \mathrm{Mg}, \mathrm{Zn}$ e $\mathrm{Cu}$ e outros elementos traço. $\mathrm{O}$ mecanismo de transporte placentário dependentes de Ca pode ser responsável pela maior via de formação de esteróide na placenta bovina. A hipofosfatemia afeta vários tipos de células. O fósforo é um componente de ácidos nucléicos, nucleotídeos, fosfolipídios e algumas proteínas, necessários 
para transferência e utilização de energia e no metabolismo de fosfolipídios. Além disso, é componente de coenzimas (HURLEY; DOANE, 1984).

A deficiência de ferro é, isoladamente, a mais comum das deficiências nutricionais do mundo. O ferro é utilizado pelas células cerebrais estando envolvido na função e síntese de neurotransmissores. Youdim, Ben-Shachard e Yehuda (1989) estudaram os efeitos da deficiência de ferro na bioquímica do cérebro e observaram diminuição significativa da neurotransmissão dopaminérgica resultante $\mathrm{DAC}$, redução do número de receptores $\mathrm{D}_{2}$ dopamina reduzindo assim o processo de aprendizagem do grupo estudado (UMBELINO; ROSSI, 2006). A necessidade de ferro resultante da dieta de um mamífero adulto é muito pequena, pois o ferro resultante da decomposição da hemoglobina é armazenado no fígado e usado novamente para a sua síntese. Animais em crescimento precisam de mais ferro e as fêmeas adultas necessitam repô-lo, pois ele é perdido nos processos reprodutivos (crescimento fetal e ciclo menstrual) (SCHIMIDT- NIELSEN, 2002).

Os principais sintomas da deficiência de $\mathrm{Cu}$ são anemias, em razão da produção deficitária de ceruloplasmina. Como conseqüência diminui a eficiência da absorção de ferro e desmineralização óssea (UAUY; OLIVARES; GONZALEZ, 1998).

A deficiência prolongada de zinco pode provocar vários danos ao organismo humano, dentre eles, anorexia; retardo no crescimento; cicatrização lenta; intolerância à glicose; hipogonadismo, impotência sexual e atrofia testicular; diminuição da atividade da interleucina-2; disfunções imunológicas, ocorrendo infecções intercorrentes; hipogeusia; desordens de comportamento, aprendizado e memória; diarréia, dermatite e alopecia (PRASAD, 1996; OMS, 1998).

O manganês é um elemento traço essencial para estrutura óssea, no qual está presente em altas concentrações, além do fígado e pâncreas. O Mn é componente de enzimas previnindo assim danos causados por oxidação lipídica no tecido. É importante na quebra de carboidratos, na síntese de oxido nítrico e no metabolismo da glicose e glicogênio (COZZOLINO, 2005).

O magnésio é o quarto elemento mais abundante no organismo. Participa de reações enzimáticas no corpo e é requerido na transmissão neuromuscular, necessário para reações envolvendo ATP, síntese de proteínas, ácidos nucléicos e transmissão de sinais nervosos (SARIS et al., 2000). Está envolvido na função imune, com efeito protetor nas membranas celulares (WEISINGER; BELLORIN-FONT,1998). A deficiência de Mg interage com a osteoporose uma vez que este elemento participa da constituição óssea (GUR et al., 2002). 
O selênio é um elemento traço, cuja essencialidade nutricional foi demonstrada em 1957 por Schwartz e Foltz (1957). Nos últimos anos têm sido descrito que baixos níveis de Se podem levar à pré-disposição para o desenvolvimento de algumas doenças, tais como câncer, esclerose, doença cardiovascular, cirrose e diabetes (NAVARRO-ALARCÓN; LÓPEZ-MARTINEZ, 2000). Neste contexto, a suplementação de dietas com Se, tanto para animais quanto para humanos, tem sido aceita pela comunidade científica. A Junta de Alimentação e Nutrição da Academia de Ciências dos Estados Unidos propõe uma ingestão diária de 50-200 $\mu \mathrm{g}$ de Se, a qual é considerada segura para indivíduos adultos (FOOD AND NUTRITION BOARD, 1989).

O cromo tem um potencial de ação no fator de tolerância a glicose (GTF), assim como qual tem efeito direto na insulina. A deficiência de cromo torna a insulina menos efetiva, resultando na diminuição da glicose nos tecidos (MERTZ, 1969). Ele também serve como um ativador enzimático.

Vários elementos existentes na dieta têm demonstrado efeitos na absorção de ferro, e por conseqüência, na sua biodisponibilidade. Estão bem documentados os antagonismos durante a absorção dos íons Fe e Ca, Fe e Zn, Ca e Zn, Cu e Zn, Mg e Ca, Mn e Zn nas vesículas das membranas das células epiteliais do intestino delgado de leitões. Estudos realizados por Bertolo, Beltger e Atkinson, (2001) e Bradley et al. (1983) demonstraram que a concentração usual de suplementação de cobre, na concentração de 120 para 240 ppm, diminui a concentração de ferro hepático de 50 a $60 \%$, por meio da competição pelos mesmos sítios de absorção na mucosa intestinal. Antes disto, Gipp et al. (1974) concluíram que o cobre, quando fornecido na dieta em concentração de 225 ppm, não apenas reduz a absorção de ferro como pode estar diretamente envolvido com a anemia ferropriva em leitões neonatos.

\subsection{ELEMENTOS TRAÇO NO DESENVOLVIMENTO EMBRIONÁRIO}

Aproximadamente $3 \%$ dos recém-nascidos têm pelo menos uma malformação congênita grave. Fatores comuns contribuem para a ocorrência de anomalias de desenvolvimento tal como a nutrição mineral desequilibrada durante o desenvolvimento embrionário e fetal. Deficiências minerais podem causar não somente malformação durante o 
desenvolvimento perinatal mas também anomalias comportamentais, imunológicos e bioquímicos que persistem na vida adulta (KEEN et al., 2003 ).

$\mathrm{O}$ alto índice de mortalidade embrionária e fetal no terço inicial da gestação de bovino é uma das maiores causas de perda econômica na produção animal (BERGER, 2004).

Há evidência crescente de que muitos defeitos no desenvolvimento embrionário ou fetal podem ser causados por aporte deficiente de nutrientes, tais como cobre, iodo, ferro, magnésio e zinco (KEEN et al., 1998).

Deficiências minerais podem alterar o desenvolvimento de tecidos fetais específicos durante períodos críticos de desenvolvimento, ou podem levar a efeitos duradouros na secreção de hormônios ou na sensibilidade de tecidos aos hormônios (GODFREY; BARKER, 2000), como será discutido adiante.

A nutrição da mãe pode alterar a programação dos genes fetais. A deficiência de zinco foi associada ao incremento de danos ao DNA, que podem resultar em perda de metilação, passível de ser transferida para a prole. A metilação do DNA geralmente provoca repressão da transcrição. Assim, a deficiência marginal de zinco na gestação pode ter efeitos deletérios permanentes na resposta imunológica (GODFREY; BARKER, 2000).

Deficiências minerais e transferência inadequada podem alterar o desenvolvimento dos tecidos fetais durante período críticos do desenvolvimento embrionário (NICODEMO; SERENO; AMARAL, 2008).

Durante o período gestacional, as exigências de micronutrientes são ampliadas em virtude do intenso crescimento e proliferação celular. A insuficiência gestacional de ferro materno pode comprometer, no concepto, o desenvolvimento do cérebro e causar alterações no metabolismo de neurotransmissores e na formação da bainha de mielina. Esta bainha rica em lipídeos reveste os axônios e é um isolante elétrico que permite uma condução mais rápida e energeticamente eficiente dos impulsos (SILVA, 2007).

A prenhez depende de concentrações específicas de progesterona e de estrógeno e as perdas embrionárias podem ser decorrentes de concentrações inadequadas desses hormônios. Alguns minerais influenciam diretamente a produção hormonal: a síntese de progesterona, necessária pelo menos durante o terço inicial da gestação na maioria dos mamíferos (HAFEZ, 1982), pode ser afetada por cálcio (Ca), zinco e manganês. Baixas concentrações plasmáticas de progesterona podem causar desenvolvimento folicular aberrante, que ocasiona a maturação anormal do ovócito no folículo ovulatório e à morte embrionária que afetam a esteroidogênese no folículo dominante e no corpo lúteo formado subseqüentemente 
e alteram também a morfologia e a função do endométrio no ciclo subseqüente (FERREIRA, 1993).

Alguns minerais apresentam propriedades antioxidativas, reduzem a incidência de distúrbios reprodutivos e melhoram o desempenho animal. Na gestação, tanto a mãe como o embrião e o feto produzem grande quantidade de espécies reativas de oxigênio, radicais livres, que têm papel importante na sinalização celular e no controle do desenvolvimento do embrião e do feto - replicação, diferenciação e maturação das células e dos órgãos (GUÉRIN; MOUATASSIM; MÉNÉZO, 2001).

O estresse oxidativo, isto é, o desequilíbrio entre a formação e a remoção de radicais livres, destaca-se na indução de patologias e em falhas na gestação. No estresse oxidativo, pode haver peroxidação de componentes celulares, conduzindo a morte celular, necrose e danos ao material genético. Esses desequilíbrios são mais freqüentes em matrizes expostas ao estresse ambiental (GUÉRIN, MOUATASSIM, MÉNÉZO, 2001). Dado o papel importante de metaloenzimas que são enzimas que possuem um íon metálico no seu grupo ativo, tais como as superóxido-dismutase e a glutationa-peroxidase, na inativação dos radicais livres, a suplementação mineral adequada pode ter papel importante para assegurar a gestação e o nascimento de um bezerro sadio.

Quando o ambiente celular se torna ainda mais oxidante, levando a morte celular programada (apoptose) e à necrose, quando o estímulo oxidativo for muito intenso. A apoptose é necessária para o desenvolvimento normal e para a destruição de células que representam ameaça à integridade do organismo (VALKO et al., 2007). Doenças e disfunções orgânicas podem estar relacionadas ao estresse oxidativo, cuja ocorrência é comum nas deficiências de elementos traço.

Estes elementos desempenham papel fundamental na regulação do potencial redox e na defesa contra o estresse oxidativo. Os tecidos dos mamíferos contêm três formas da metaloenzimas superóxido-dismutase, duas que contêm cobre e zinco e uma terceira que contém manganês. A superóxido-dismutase converte superóxido em peróxido de hidrogênio; a catalase, uma metaloenzimas que contém ferro, converte o peróxido de hidrogênio em água e oxigênio molecular. 


\subsection{PLACENTA BOVINA}

Desde o início, a placenta influencia a homeostase materna. É um órgão vital para o desenvolvimento e crescimento fetal, e metabolicamente muito ativo, é de crucial importância clínica, as exigências do feto e da placenta devem estar em estreita harmonia, em especial em situações em que o fornecimento de nutrientes é precária, se a placenta está carente de nutrientes o feto também não irá sobreviver. Uma grande parte da mortalidade embrionária bovina ocorre em fêmeas saudáveis em decorrência de uma comunicação materna embrionária deficiente, que impedem a gestação (WOLF et al., 2003). O alto índice de mortalidade embrionária e fetal no terço inicial da gestação de bovino é uma das maiores causas de perda econômicas na produção animal. É constituída por uma parte fetal e uma materna, sendo o único órgão formado por células de dois indivíduos (JUNQUEIRA; CARNEIRO, 1995).

A placenta desempenha diversas funções, como servir o feto no lugar do pulmão, rim e do intestino durante o período em que estes órgãos estão sob desenvolvimento e ainda não estão em funcionamento adequado. A placenta atua como um regulador, fornecendo os nutrientes necessários ao feto até que estes órgãos estejam funcionalmente operantes. Todas as funções da placenta são mediadas por uma barreira formada entre a circulação materna e fetal. Nesta barreira estão presentes (nesta ordem): na porção materna: o endotélio capilar, tecido conjuntivo e epitélio; e na porção fetal: o trofoblasto, tecido conjuntivo e endotélio capilar. Esta barreira difere de uma espécie para outra, diminuindo as camadas maternas (LEISER; KAUFMANN, 2004)

Há um grande gasto energético no cruzamento desta barreira. Um terço do oxigênio e da glicose provenientes da mãe é gasto unicamente para assegurar estas transferências. Os outros 2/3 restantes atingem ao feto. Existem diferentes possibilidades para a ocorrência destes transportes e a maioria ocorre por transporte ativo realizado pelo sinciotrofoblasto (SOUZA et al. 2007).

O fluxo sanguíneo materno-fetal da placenta bovina é, inicialmente, multiviloso e tende a torna-se contracorrente, o que o diferencia da placenta humana, no qual as células trofoblásticas ficam diretamente em contato com o sangue materno (LEISER; KAUFMANN; 1994).

O crescimento placentário não acompanha o mesmo ritmo do crescimento fetal. O crescimento da placenta nos estágios finais da gestação equivale à quantidade de nutrientes 
que está a disposição do feto, sugerindo então que a placenta cresce além de suas necessidades no início da gestação, preparando-se para a grande demanda metabólica do crescimento fetal nos estágios finais da gestação (ALMEIDA et al., 2000).

A passagem e a troca de nutrientes da mãe para o feto são realizadas por meio dos vilos placentários (MAYHEW, 2002). Nas regiões das trocas materno-fetais observou-se diferença estrutural e morfológica significativa entre a placenta de animais clonados comparados aos animais controle.

A fonte de nutrientes pode ser hemotrófica, ou seja, diretamente dos capilares maternos, ou histiotrófica, cuja nutrição ocorre de secreções das glândulas uterinas ricas em enzimas, citosinas, fatores de crescimento, íons, tais como o ferro, hormônios, glicose, proteínas de transporte e moléculas de adesão (GRAY et al., 2001a, b).

As vilosidades placentárias apresentam-se das mais variadas formas dependendo da espécie animal considerada. Nos bovinos assumem o aspecto de uma árvore cilíndrica constituída de um tronco principal que se ramifica progressivamente em vilos de ordens menos elevadas. Geralmente eles se encaixam em criptas correspondentes, onde os septos principais emitem septos secundários para formar o constituinte materno (PINTO, 2002). A função destas vilosidades é colocar os vasos fetais (alantóide em proximidade com os vasos sanguíneos maternos) (JAINUDEEN; HAFEZ, 2005).

De acordo com a classificação dos tipos placentários existentes nos animais e a passagem de substâncias pela barreira inter-hemática, a transferência de ferro nas placentas corioalantóide pode ser realizada por 3 mecanismos: absorção de ferro ligado a transferrina através da superfície externa do trofoblasto em contato direto com o sangue materno circulante (placenta hemocoriais), absorção de eritrócitos maternos pelo epitélio coriônico em contato direto com acúmulo de sangue materno extravasado em áreas hemófagas (placenta endoteliocoriais e sinopiteliocoriais), absorção de ferro pelo epitélio coriônico em contato direto com secreções ricas em ferro proveniente das glândulas endometriais (placenta difusa).

As estruturas anatômicas que regulam ativamente as taxas de transferência em cada direção para cada tipo de molécula, situadas entre os dois compartimentos materno e fetal (sinciotrofloblasto e endotélio fetal) concentram-se nas vilosidades secundárias e terciárias, que são sítios de crítica regulação de transferência de nutrientes. A interface fetal é constituída por uma fina camada de sinciotrofloblasto, entre o sinciotrofloblasto e os capilares das células endoteliais reside uma fina camada de matriz extracelular. As camadas (sinciotrofloblasto com sua membrana basal, a matriz extracelular, e as células endoteliais 
com a membrana basal subendotelial) contém todos os elementos essenciais das estruturas e os mecanismos da barreira hemato-placentária e todos os dois compartimentos (Figura 1). Estas estruturas não fetais não só trocam o material com sangue materno, mas também regulam o fornecimento de sangue. Na fisiologia humana o sinciotrofloblasto apresenta uma barreira mais efetiva. A barreiras das células endoteliais variam sua propriedade de transferência, de acordo com os diferentes órgãos e os diferentes níveis da árvore vascular (ATKINSON; BOYD; SIBLEY, 2006).

O transporte de elementos traço da placenta para o feto pode ser dividido em grupos: grupo I: elementos $\mathrm{B}, \mathrm{Si}, \mathrm{V}$, As e Ni que são transportados para a placenta do sangue materno e somente se acumulam na placenta grupo II: elementos, $\mathrm{Na}, \mathrm{Co}, \mathrm{Ge}$ e $\mathrm{Rb}$ os quais são transportados para a placenta do sangue materno e se acumulam na placenta, feto e fluido amniótico, grupo III: elementos $\mathrm{Mn}, \mathrm{Fe}, \mathrm{Zn}$ e Se são transportados para a placenta do sangue materno e sobretudo acumulam-se no feto (ENOMOTO; HIRUNUMA, 2001).

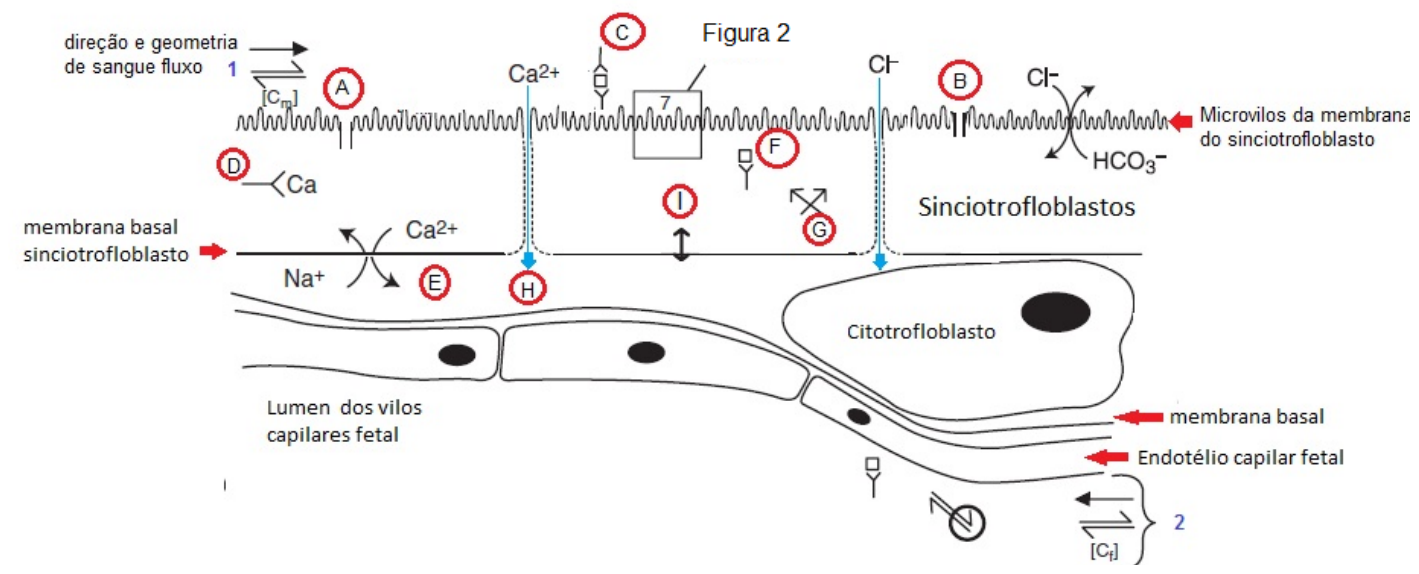

Fonte: Adaptado de Atkinson, Boyd, Sibley, (2006)

Figura 1 - Mecanismo de transporte de minerais através do tecido placentário (1). Direção do fluxo de sangue materno (2). Direção de transferência entre a placenta e o sangue fetal e dos seus componentes envolvendo alguns ou todos os elementos (A). Canal para cálcio (B). Canal de sódio, (C). Proteína transportadora e receptora de membrana de solutos (por exemplo, ferro), (D). Proteína de ligação do cálcio (E). Permutador de $\mathrm{Na} / \mathrm{Ca}^{2+}(\mathrm{F})$. Encadernação moléculas supostamente envolvidos no movimento através sinciotrofoblasto (proteínas transportadora), (G). Interconversão interplacental metabólica ou catabolismo, (H). Via de transferência de água e íons $(\mathrm{Ca}$ e $\mathrm{Cl})$. I. Mecanismos de transporte na membrana basal sincicial

Os tipos de transporte de substância através da placenta são variáveis, podem ser por difusão passiva que será determinada por taxa de fluxo de gradiente de concentração, equilíbrio constante ácido-base (JOHNSON et al., 1997), a solubilidade lipídica (BISSONNETTE, et al., 1979), peso molecular (EICHHORN, et al., 1993; 
REISENBERGER et al., 1997), análise funcional durante o metabolismo (SCHENKER et al., 1999), ou difusão facilitada e transporte passivo, filtração ou pinocitose. A regulação da atividade do transporte é de importância crítica para saúde fetal (Figura 2).

Um dos prováveis fatores que pode contribuir para a incidência de morte embrionária pode estar relacionado com o fornecimento inadequado de minerais para os tecidos fetais ou embrionário. A transferência inadequada desses elementos da mãe para o feto resulta num desequilíbrio mineral ocasionando, em alguns casos, podendo ocasionar danos ao crescimento fetal (HOSTELLER; KINCAID; MIRANDO, 2003; EMBRAPA, 2009).

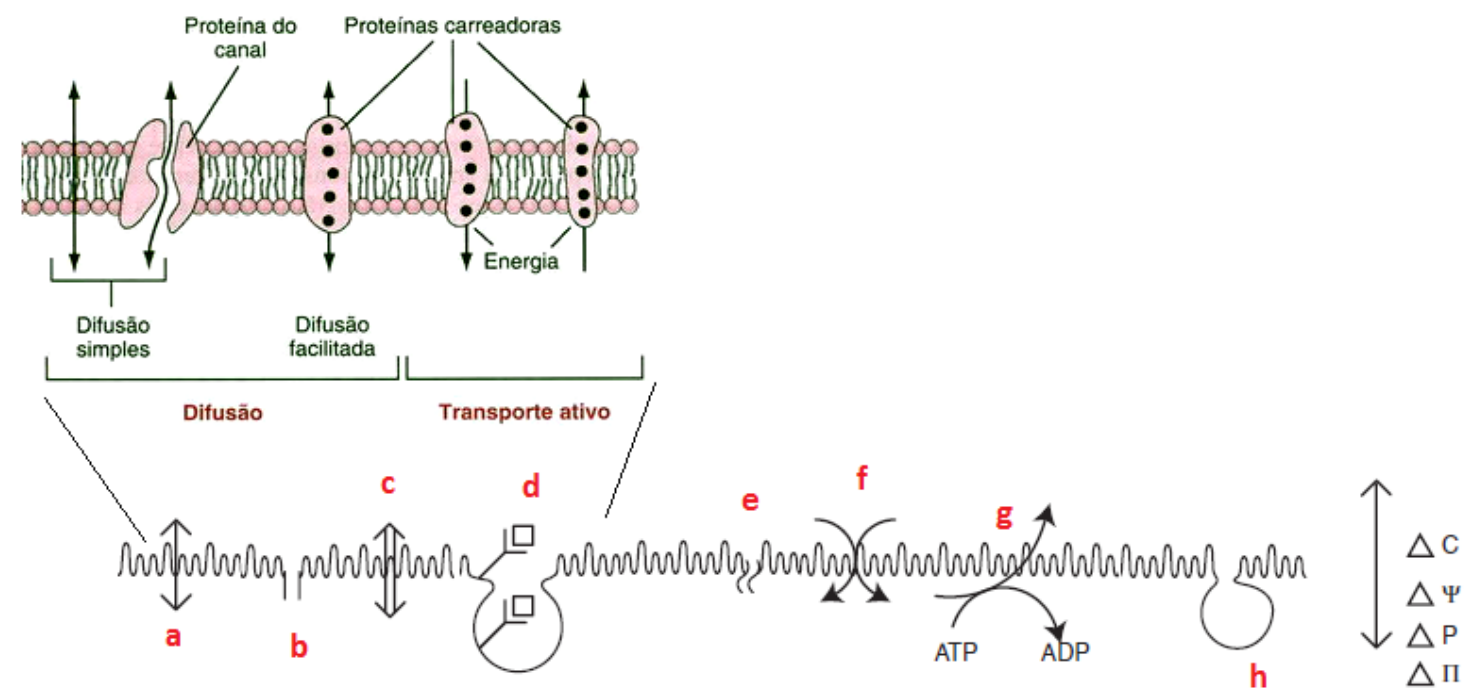

Fonte: Adaptado de Atkinson, Boyd, Sibley, (2006)

Figura 2 - Mecanismos de transferência através da microvilosidades do sinciotrofoblasto (a) difusão simples (b) canais de íons (por exemplo, $\mathrm{Cl}^{-}, \mathrm{Ca}$ ) (c) Difusão facilitada (d) Endocitose mediada por receptor ligado ao soluto (por exemplo, ferro, IGG) (e) aquaporina (por exemplo, transporte de água) (f) Co-transporte (alanina e sódio) (g) Transporte impulsionado ativo, ATP-ADP (por exemplo, $\mathrm{Na}+$ troca por $2 \mathrm{~K}$ ) (h) Receptor de endocitose mediada. $\Delta \mathrm{C}$, as diferenças de concentração; $\Delta \Pi$, diferenças de pressão osmótica, $\Delta \mathrm{P}$, diferenças de pressão hidrostática; $\Delta \Psi$, diferença de potencial elétrico, todos expressos em todo o microvilosidades da membrana 


\subsection{PLACENTA DE BOVINO CLONADO}

A clonagem ou transferência nuclear é uma técnica que permite a geração de um organismo geneticamente idêntico a outro (CAMPBELL; SMITH; SAYRE, 1996). Inúmeras aplicações da técnica de transferência são utilizadas na pecuária e na medicina humana.

Das alterações mais relevantes descritas em gestações de clones, os mais citados são o peso aumentado da placenta e do bezerro ao nascimento. Diferentes trabalhos mostram que tanto o peso da placenta como do bezerro em gestações de clones são iguais ao de animais produzidos por inseminação artificial até o terço final de gestação (CONSTANT et al., 2006).

Além das anormalidades, quando o feto atinge o final da gestação, a receptora não apresenta os sinais do parto, como amojo e dilatação de cérvice mesmo quando o feto já está apresentando sinais de sofrimento, fetal fazendo assim necessário a cirurgia cesariana (WELLS et al., 1999; HILL et al., 2000).

Os resultados de Constant et al. (2006) mostraram que o número de placentônios antes de 220 dias de gestação é menor nos clones comparados com o GCOntrole, mas a média de peso dos placentônios foi maior nos clones. O peso dos fetos foi muito semelhante. Entretanto após 220 dias o número de placentônios fica igual entre os grupos controle e clone, mas a média dos pesos, dos placentônios, o peso total da placenta e o peso do feto foram maiores no GCLonado.

O papel dos elementos traço na nutrição animal encontra-se em aberto na literatura científica e requer investigação aprofundada. O conhecimento de níveis necessários, efeitos negativos nas deficiências, toxicidades, interações antagônicas são necessários para realização de diagnósticos precisos, intervenções e tratamentos eficazes para otimização da produtividade e bem estar animal (SINGH et al., 1995; BECKER et al., 2005; JOHNSTON, 2005; PEIXOTO, 2005). Com base nos aspectos acima abordados iniciamos as investigações na perspectiva de introduzir novas considerações sobre os elementos constituintes e traço no tecido placentário. 


\subsection{FUNDAMENTAÇÃO TEÓRICA FLUORESCÊNCIA DE RAIOS X}

Roentgen em 1895 descobriu uma nova espécie de radiação que ele denominou de raios $\mathrm{X}$, quando realizava experimentos de descargas elétricas dentro de um tubo de vidro onde o ar tinha-se rarefeito. Observou-se que chapas fotográficas cobertas com papel escuro e deixadas próxima ao tubo eram sensibilizadas A partir desse momento, Roentgen realizou a primeira chapa fotográfica da mão de sua esposa, mostrando claramente a reprodução da forma de um objeto oculto em um envoltório opaco à luz, desde que se colocasse o objeto entre o tubo e a chapa fotográfica. A primeira aplicação dos raios X foi na Medicina, e posteriormente na Indústria e na pesquisa científica. A primeira evidência da aplicação de raios X para análise elementar foi descrita por Barckla em 1911 no começo deste século, a partir da observação das características dos espectros, mas foi Moseley em 1913 que estabeleceu as bases analíticas espectrais de raios $\mathrm{X}$, relacionando o comprimento de ondas, linhas características com os números atômicos dos elementos. Desde então, a fluorescência de raios X (XRF-X-Ray Fluorescence) desenvolveu-se como um processo analítico.

Os raios $\mathrm{X}$ emitidos por um tubo de raios $\mathrm{X}$ ou radiação gama por uma fonte radiativa, excitam os elementos constituinte da amostra, os quais, por sua vez, emitem linhas espectrais com energia característica do elemento e cujas intensidades estão relacionadas com a concentração do elemento na amostra.

Com o surgimento da espectroscopia de fluorescência de raios $\mathrm{X}$, a mesma não pôde ser amplamente aplicada em nível microscópico como as técnicas de microssonda de elétrons ou prótons. Isto ocorre em razão das dificuldades ópticas de focalizar o feixe de raios $\mathrm{X}$ comparado com feixe de partículas carregadas. A solução surgiu com o aparecimento da teoria de reflexão total na faixa de raios $\mathrm{X}$, possibilitando a construção de dispositivos concentradores de radiação eletromagnética (os capilares), e o desenvolvimento da tecnologia de tubos de raios X com alta intensidade (JANSSENS; VINCZE; ADAMMS, 2000).

A espectrometria de fluorescência de raios X é habitualmente utilizada para análises elementares qualitativas e semi-quantitativas de amostras com composições distintas e para aplicações diversas. Comparada às outras técnicas competitivas quanto à informação fornecida, como a espectroscopia por absorção atômica (AAS), a espectroscopia com fonte de plasma induzido (ICPS) e análise por ativação com nêutron instrumental (INAA), apresenta a vantagem de ser não destrutiva, multielementar, rápida e de custo acessível. 
Possui um limite de detecção aceitável para a maior parte dos elementos da tabela periódica e é aplicável para baixas concentrações da ordem de poucas partes por milhão (ppm) (BERTIN, 1970).

Resumidamente, podemos dizer que a análise por fluorescência de raios X consiste de três fases: excitação dos elementos que constituem a amostra, dispersão dos raios $\mathrm{X}$ característicos emitidos pela amostra e detecção desses raios $\mathrm{X}$. Dois processos são importantes na fluorescência de raios $\mathrm{X}$ : efeito fotoelétrico e espalhamento Compton e Rayleigh. O primeiro influencia positivamente na análise por fluorescência, ao passo que o segundo é um processo físico indesejável, pois aumenta o background espectral. Tais processos encontram-se amplamente discutidos na literatura (EISBERG, 1988; KNOLL, 1999).

O detector semicondutor de $\mathrm{Si}$ (Li hiperpuro), denominado de alta resolução na década de 60, têm a capacidade de separar diretamente os raios $\mathrm{X}$ característicos, possível o surgimento da fluorescência de raios X por dispersão de energia (EDXRF, Energy dispersive X-Ray fluorescence), com instrumentação menos dispendiosa e emprego mais prático. Esta técnica vem sendo utilizadas em particular para amostra sólidas, permitindo a determinação simultânea ou seqüencial da concentração de vários elementos, sem a necessidade de destruição da amostra, ou seja, de modo instrumento, sem nenhum pré-tratamento químico (NASCIMENTO, 1999).

As sub variantes da técnica EDXRF, além da convencional, são: (1) a fluorescência de raios $\mathrm{X}$ por reflexão total, possuindo vantagens como quantidades diminutas das amostras (da ordem de $5 \mathrm{ml}$ ) e menores valores de limites de detecção em relação à EDXRF convencional; (2) a microfluorescência de raios $\mathrm{X}$ ( $\mu \mathrm{XRF}$ ), sendo a única a fornecer informações sobre a distribuição elementar na amostra. Nestas técnicas e variantes, normalmente se utiliza raios $\mathrm{X}$ de elementos alvo (Mo, Rh, etc.) de um tubo de raios $\mathrm{X}$, e mais recentemente raios $\mathrm{X}$ provenientes da fonte Síncrotron.

A determinação de elementos traço para amostras biológicas tem sido efetuada por muitos pesquisadores com distintas técnicas (CARVALHO; CUSTODIO; REUS, 2001; POLLETI et al., 2004; ANJOS, 2004). Para fundamentarmos esta proposta de análise discorremos, na seqüência, sobre algumas características e peculiaridades dos elementos avaliados.

Analisar os níveis dos elementos traço em tecidos biológicos é relevante no diagnóstico e tratamento de determinadas patologias (TAKAHASHI; TANAKA;SANO, 1981), uma vez que é possível correlacionar seus níveis de concentração ao desenvolvimento 
de certas patologias e neoplasias (MARCÓ; CARABALLO; PASCUSSO, 2003). Essa correlação é possível, pois a deficiência ou o excesso de elementos traço, como por exemplo, manganês, ferro, níquel, cobre, zinco e chumbo podem resultar em distúrbios neurológicos (SINGH; DHAWAN; CHAND, 1995; BECKER; ZORIY; PICKHARDIC, 2005).

Avanço significativo na compreensão da relevância dos minerais no desenvolvimento e formação de tecidos biológicos, em especial, na determinação de suas concentrações ocorreu a medida que métodos analíticos foram concebidos. Assim, estudos sistemáticos visando a mensuração da resposta dos animais à suplementação de minerais separadamente levantaram novas hipóteses sobre o papel dos nutrientes e sua importância efetiva (MCDOWELL, 1999; UNDERWOOD; SUTTLE, 1999). 


\section{4 \\ MATERIAL E MÉTODOS}

\subsection{PLACENTA BOVINA}

A placentação em ruminantes refere-se à junção do córion com o epitélio uterino, resultando na placenta e nos placentônios, que são as unidades morfofuncionais (ATKINSON, 1987; LATSHAW, 1987; LEISER et al., 1997 ;HAFEZ ; HAFEZ, 2004; KING;). A placenta de ruminantes é classificada multicotiledonária e sinepiteliocorial (LEISER; KAUFMAN, 1994; PEREIRA, 2004; CARVALHO et al., 2006). É classificada como zonaria, em vez de ter uma única grande área de contato entre os sistemas vasculares materno e fetal. Apresenta áreas especializadas de aposição e proliferação das membranas materna e fetal, os placentônios, que constituem a união entre carúncula materna e cotilédone fetal (Figura 3). Nesta interface ocorrem as trocas metabólicas indispensáveis para o desenvolvimento do concepto. A placenta é composta de duas partes: a placenta fetal ou corioalantóide e a placenta materna ou endométrio (ROBERTS, 1986).

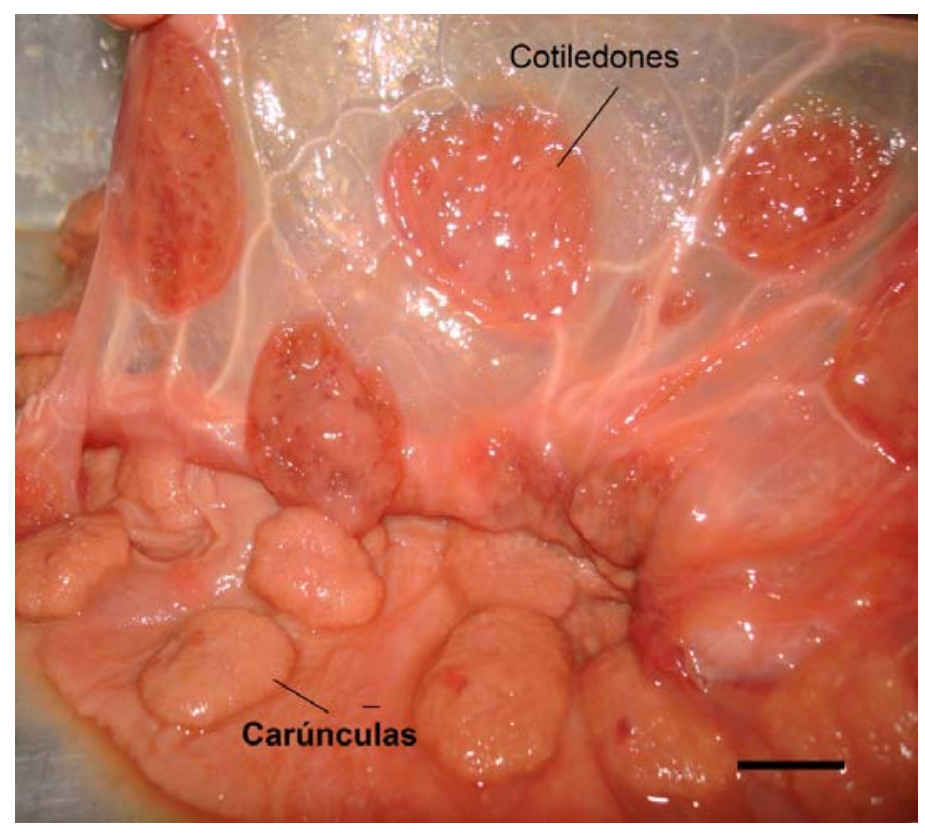

Figura 3 - Placenta bovina com 90 dias de gestação carúnculas e cotilédones identificados na imagem. Barra 2,5 $\mathrm{cm}$

Segundo Hafez e Hafez (2004) o processo de aderência em ruminantes envolve as áreas carunculares (região placentomal) e a região intercarunculares endometriais (interplacentomal). Caracteriza-se pelo aparecimento destas células binucleadas, que crescem 
a partir das células mononucleadas do trofoblasto. Tais células migram e se fusionam ao epitélio uterino formando assim as células multinucleadas ou um sincício, eventualmente relacionados à defesa imunológica do feto e na transferência de lactogênio placentário, por elas sintetizado, à circulação materna.

$\mathrm{Na}$ região interplacentomal há uma aposição entre membrana fetal e epitélio uterino, onde encontramos as glândulas uterinas. A absorção das secreções das glândulas uterinas é importante na nutrição fetal durante a gestação de ruminantes. Nos placentônios a superfície endometrial possui profundas criptas carunculares, penetrados por longos e ramificados vilos cotiledonários de corioalantóide fetal, o que aumenta extremamente a área de contato superficial entre mãe e feto. Os microvilos permitem a absorção de materiais por difusão facilitada ou endocitose.

Durante a implantação há um desenvolvimento de papilas trofoblásticas nas áreas em que o concepto se aproxima da abertura das glândulas uterinas, situadas na região interplacentomal, e o contato destas papilas com o lúmen glandular, permite a absorção, ao nível de estruturas absortivas especializadas ou aréolas placentárias, de proteínas e substâncias. O histiotrofo (leite uterino), é composto de enzimas, fatores de crescimento, citosinas, linfocinas, hormônios, proteínas de transporte e outras substâncias nutritivas. Nestas aréolas ocorre fagocitose de leite uterino pelas glândulas trofoblásticas, de modo semelhante, na zona arcada (situada entre as bases dos vilos cotiledonários, na região do topo dos vilos maternos, em que há contato entre ambos), células mononucleadas de revestimento estão envolvidas na fagocitose de macromoléculas, especialmente eritrócitos, as células trofoblásticas podem englobar leucócitos materno, células epiteliais vizinhas e células gigantes (MYAGKAYA; SCHELLENS, 1981).

\subsubsection{Amostras Biológicas}

Foram obtidas 15 amostras de placentônios bovinos não-manipulados da linha de abate no Matadouro Mantiqueira em São José dos Campos - SP. Coletou-se 6 úteros gravídicos de bovinos clonados (Figura 5). Os bovinos clonados foram produzidos pela equipe Minerembryo Reprodução e Produção Animal Ltda - Alfenas - MG, sendo que, as manipulações de embriões clonados foram realizadas pela equipe coordenada pelo professor Dr. Flávio Meirelles da FZEA- USP - Clonest Biotecnologia Animal - Pirassununga-SP. As fêmeas receptoras destes embriões clonados foram sacrificadas em matadouro para colheita 
do útero. As medidas cefalococcígeas dos fetos (CR - "Crown-Rump") foram determinadas para estimar a idade de prenhez. Realizou-se um estudo comparativo entre os valores obtidos para animais não manipulados e clonados pela fórmula: $\mathrm{X}=2,5(\mathrm{Y}+21)$ (RICHARDSON, 1989).

Os grupos foram determinados de acordo com a idade gestacional: Grupo I - 90 dias de gestação, Grupo II - 135 dias de gestação, Grupo III - 225 dias de gestação.

O primeiro e mais importante passo para qualquer análise é preservar a integridade da amostra (WATT; LANDSBERG, 1993). A Figura 4 esquematiza o protocolo seguido para preparação e avaliação das amostras. A maioria dos tecidos dos mamíferos é macio, logo, na maioria das vezes necessita de fixação antes do seccionamento. Contudo, qualquer fixador, como por exemplo, glutaraldeido ou álcool, eventualmente irá alterar a distribuição dos elementos traço no tecido através da retirada, inclusão ou até mesmo a modificação regional dos elementos traço.

A criopreservação é uma técnica de preparação em que os tecidos e as células são rapidamente congelados mantendo dessa maneira sua integridade. É considerada a melhor forma de preparação das amostras tanto para estudo morfológico de alta resolução quanto para análise de composição química (WATT; LANDSBERG, 1993). Por esta razão, após a coleta, as amostras de placenta bovino foram transportadas em caixa de isopor com gel térmico congelados e, então posteriormente acondicionadas em freezer a temperatura de $4 \circ$ C.

Com o intuito de corrigir efeitos referentes a possíveis contaminações, amostras foram preparadas de maneira análoga às amostras de análises, contendo apenas água. Permitindo verificar, dessa maneira, a qualidade dos materiais utilizados no preparo das amostras. Para garantir superfície livres de contaminação por metais, fez-se o uso de materiais de plástico e vidro (devidamente lavados com água purificada e esterilizados) para armazenar as amostras.

Esse projeto foi submetido e aprovado pelo Comitê de Ética da Faculdade de Medicina Veterinária e Zootecnia de São Paulo. 


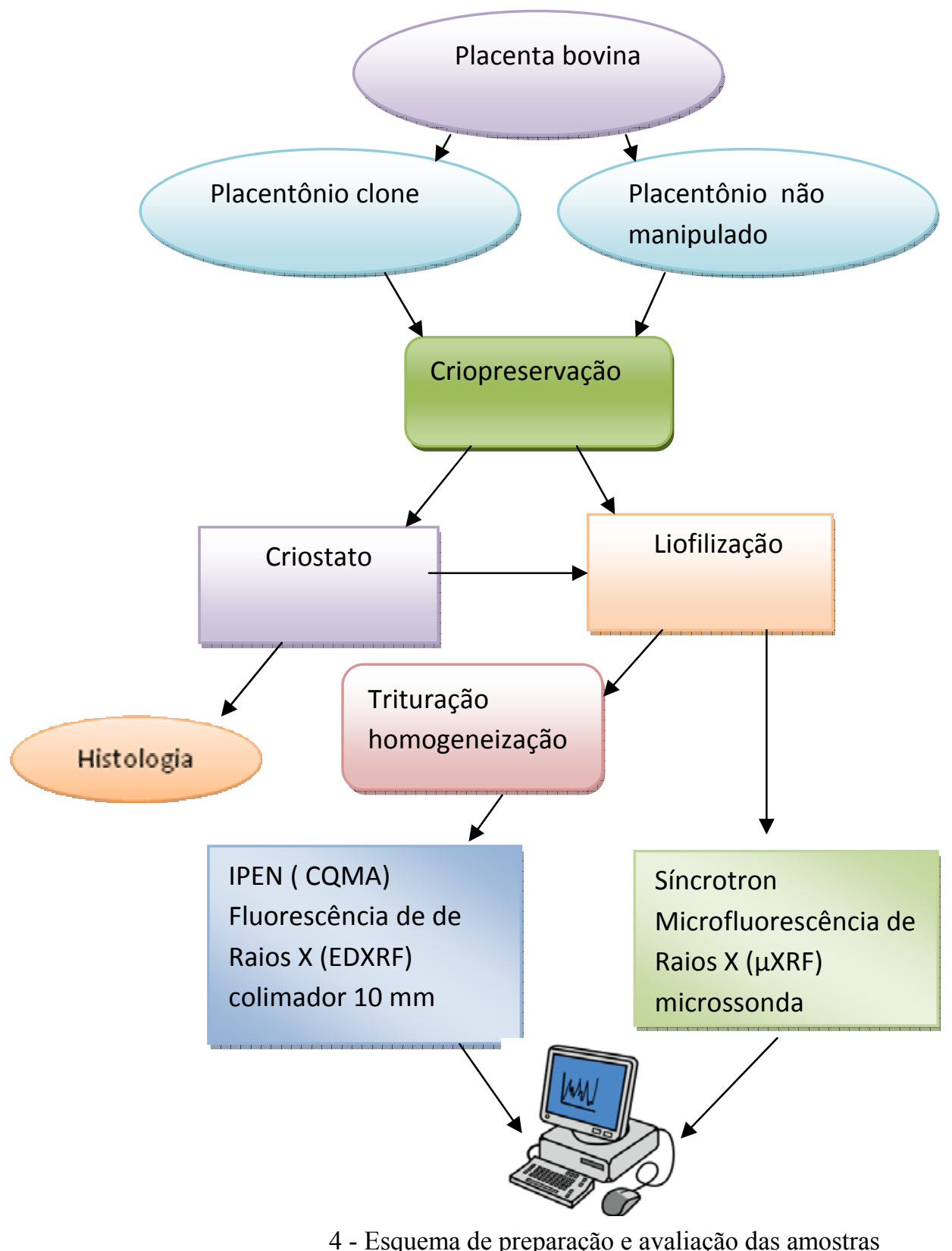

4 - Esquema de preparação e avaliação das amostras

\subsection{MACROSCOPIA}

Os úteros (Figura 5) foram dissecados e efetuou-se uma incisão uterina dorsal a cérvix percorrendo a curvatura maior dos cornos uterinos (evitando a secção dos placentônios), seguiu a mensuração do "Crown-Rump" embrionário ou fetal, utilizando-se fita métrica $(1 \mathrm{~m})$, e a inversão do útero e exposição dos placentônios para registro fotográfico e análise macroscópica quanto ao número e tamanho (largura, comprimento e 
espessura) as medidas foram realizadas utilizando-se um paquímetro digital 6" de aço inoxidável (Western ${ }^{\circledR}$ DC-60) com divisão em centímetros e milímetros. Os valores obtidos, tais como número, tamanho (comprimento), forma dos placentônios estão apresentados na figura 6 .

Para cada útero coletado obtiveram-se amostras de diferentes regiões placentárias conforme pode ser visualizado na figura 7.

- Placentônios - região central (PLC), região marginal (PLM)

- Áreas interplacentomais (IPL)

Classificamos os placentônios, de acordo com a medida de seu eixo maior em microplacentônios - menor ou igual a $1 \mathrm{~cm}$; pequenos - entre 1,1 a $3 \mathrm{~cm}$; médios - entre 3,1 a $6 \mathrm{~cm}$; grandes - entre 6,1 a $11 \mathrm{~cm}$ e megaplacentônios - maior que $11 \mathrm{~cm}$.

Amostras de diferentes regiões placentomais foram coletadas e devidamente identificadas. Estas foram cortadas em cubos (Figura 8) de aproximadamente 0,5 cm e acondicionadas em nitrogênio líquido. Com o objetivo de não ter perda significativa em relação a concentração dos micronutrientes, as amostras foram armazenadas em freezer a temperatura de $-70^{\circ} \mathrm{C}$ visando a avaliação por fluorescência de raios $\mathrm{X}$.

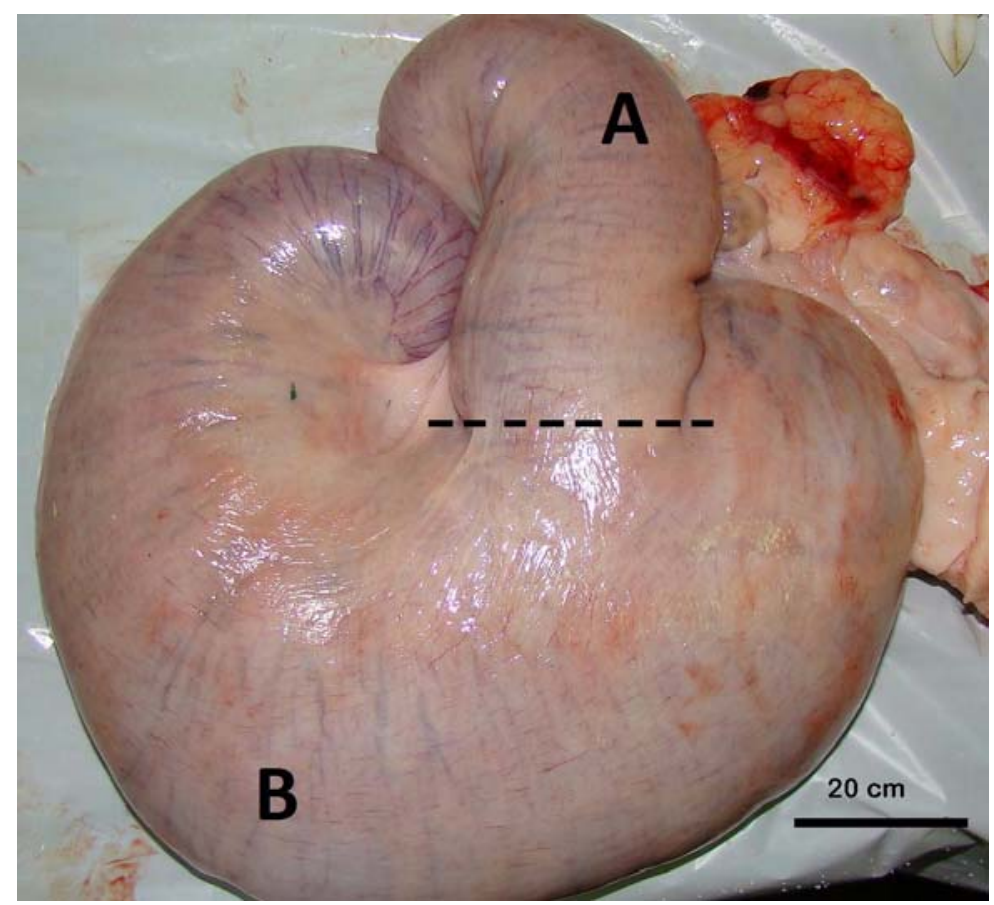

Figura 5 - Útero gravídico A) Corno não gestante B) Corno gestante. Barra: $20 \mathrm{~cm}$ 


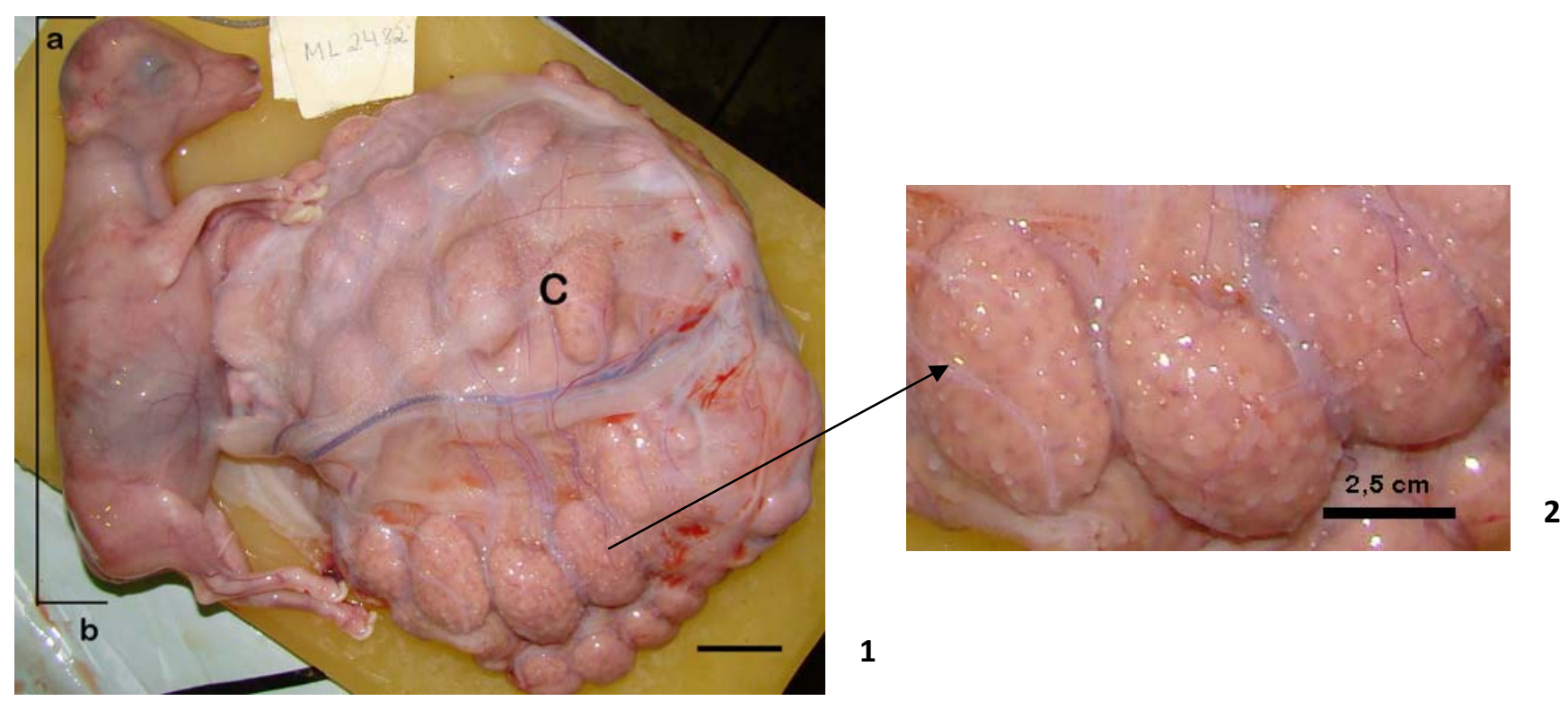

Figura 6 - Corno gestante aberto exposição de feto e placenta. 1) de a - b medida "Crow Rump" do feto, c) placenta bovina, fileiras de placentônios, 2) placentônios. Barra (1) $20 \mathrm{~cm}$ (2) $2,5 \mathrm{~cm}$

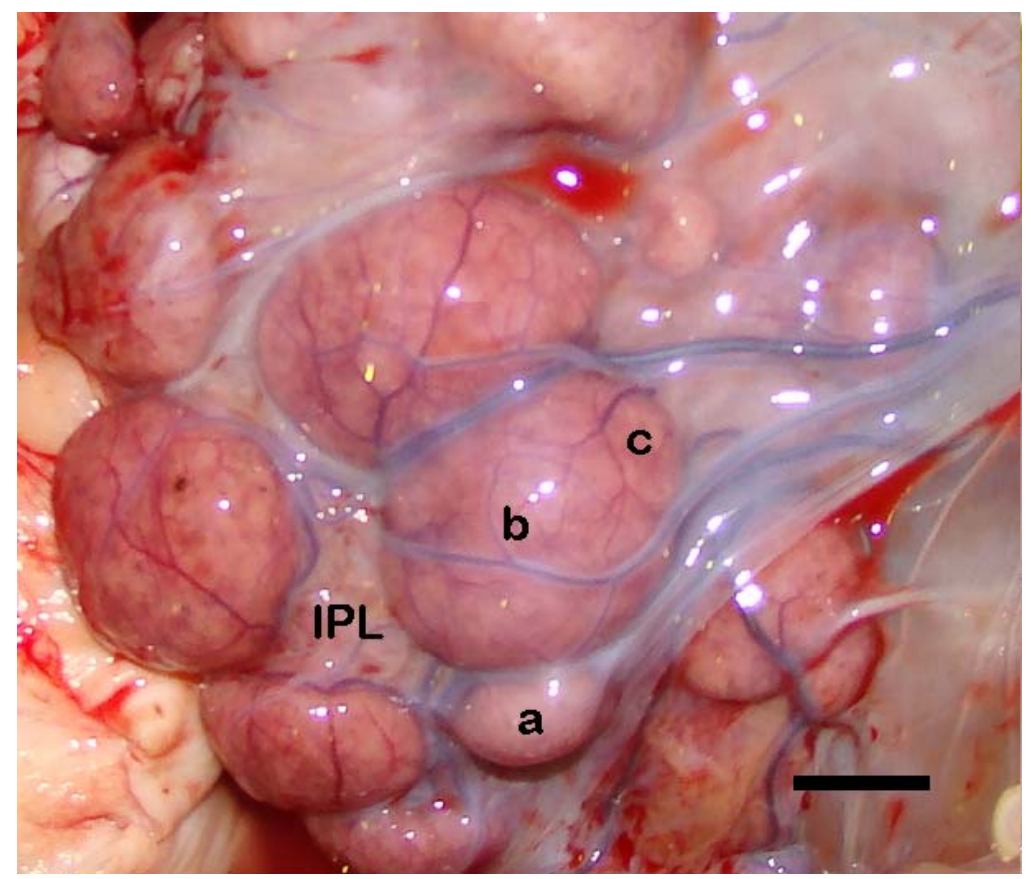

Figura 7 - Placentônios bovinos e região inter placentomal (IPL) , a) MiPL - Microplacentônio (0,90 cm), b) PLC - Parte central do placentônio, c) PLM - Parte das margens do placentônio. Barra: $10 \mathrm{~cm}$ 


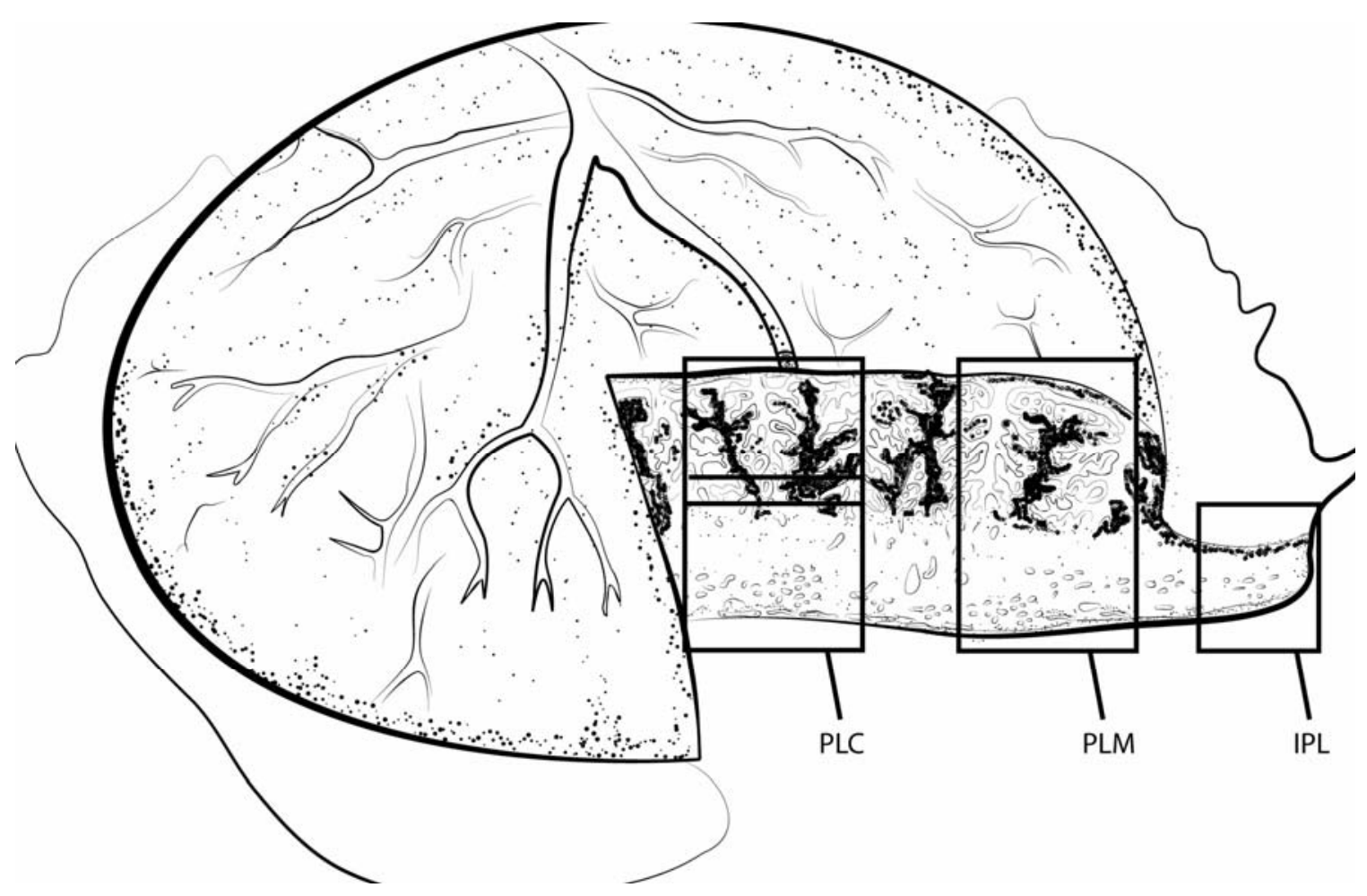

Figura 8 - Esquema de corte placentônio para separação das regiões distintas, na qual PLC - a região central, PLM - região marginal, IPL - região entre os placentônios

\subsection{MICROSCOPIA}

Os fragmentos de placentônios foram congelados a $-70^{\circ} \mathrm{C}$ segundo o método de congelamento de tecido não fixado (DAL PAI, 1995) e armazenados em botijão de Nitrogênio $\left(-196^{\circ} \mathrm{C}\right)$. A microtomia do material foi realizada em micrótomo automático (Leica, CM $1850 \mathrm{UV}$ ) a $-20{ }^{\circ} \mathrm{C}$, (Figura 9) obtendo se cortes de $5 \mu \mathrm{m}$ com auxílio de navalhas descartáveis. De cada bloco foram selecionados um cortes, com $2 \mathrm{~mm}$ de espessura, para serem liofilizados e posteriormente serem armazenados em freezer com temperatura de $-80^{\circ} \mathrm{C}$ para preservação dos cortes. 


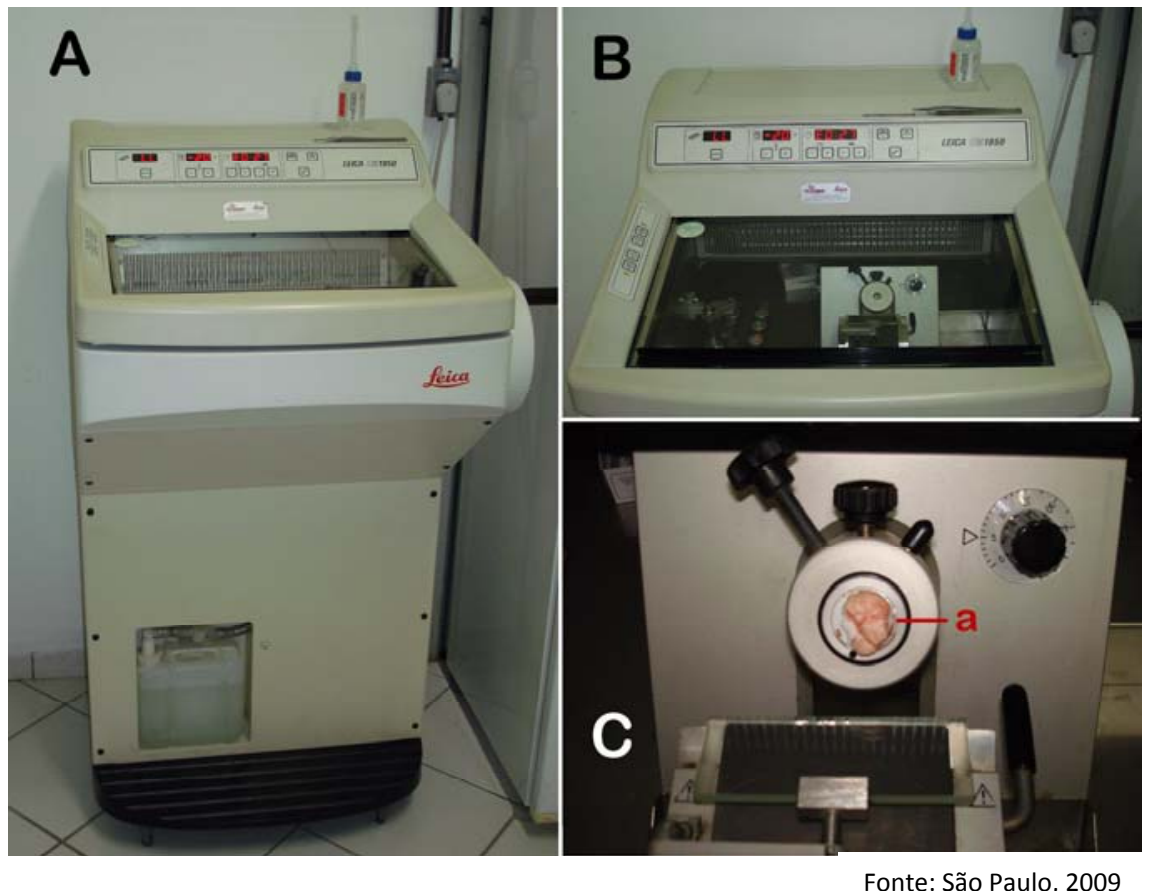

Figura 9 - A) Criostato Leica CM 1850, B) Vista do micrótomo, C) Vista do Bloco Térmico do micrótomo (a) amostra fixada no disco, posicionado no bloco térmico

\subsubsection{Coloração por Hematoxilina-Eosina (HE)}

Assim, foram selecionados alguns cortes de $5 \mu \mathrm{m}$ para a análise microscópica e foram coradas pelo método Hematoxilina e Eosina segundo a técnica de Behmer, Tolosa e Freitas Neto (1976). As leituras das lâminas foram realizadas em microscópio de luz Nikon Eclipse E-800.

\subsection{TÉCNICAS EXPERIMENTAIS}

A acurária das medidas foi verificada através da determinação da concentração elementar em uma amostra certificada de fígado bovino (NIST1577b) (ANEXO A), preparada por trituração seguindo o mesmo preparo das amostras de placenta. 


\subsubsection{Fundamentos teóricos sobre liofilização}

A liofilização é um método prático de preservação de amostra em razão da eliminação da água e alteração de proteínas, destruindo quase completamente enzimas e bactérias, baseada no fenômeno de sublimação. Componentes de uma amostra em estado líquido tendem a ter maior grau de interação com o recipiente do que amostras em estado sólido, causando com isso alguma reação química, que podem causar alteração em sua constituição química.

A liofilização pode ser considerada como um processo de secagem de um produto previamente congelado no qual o solvente, geralmente a água, é removida primeiramente por sublimação seguida pela desorção da mesma até atingir níveis de umidade residual satisfatório para impedir o desencadeamento de reações químicas, físicas e biológicas. $\mathrm{O}$ processo de liofilização remove a água de um sistema, baseado no princípio da sublimação do gelo sob pressão reduzida. Quando, por exemplo, uma solução protéica é liofilizada, os cristais de gelo presentes na região intersticiais da solução superconcentrada congelada deixará a matriz através da sublimação. As multicamadas da água que envolve a molécula de proteína são removidas posteriormente por desorção, deixando uma monocamada residual de água na superfície da proteína. Esta operação permite a secagem de material termolábeis com o objetivo de diminuir o conteúdo de unidade residual sob condições de temperatura moderada. Se o produto cujo fim é o uso parental, então a proteína geralmente liofilizada em um recipiente final tal como a ampola de vidro lacrada ou um recipiente de vidro com fecho de borracha que é usualmente fechado a vácuo ou nitrogênio.

O conteúdo de água do material liofilizado no recipiente final pode variar dependendo dos parâmetros da liofilização, podendo esse, aumentar durante o armazenamento (TOWNS, 1995).

\subsubsection{Preparação das amostras}

As amostras foram devidamente identificadas (corte histológico $2 \mathrm{~mm}$, cubo $0,5 \mathrm{~cm}$ ). Todas as amostras (Figura 10) foram liofilizadas no equipamento de bancada (Terroni série 
LC) por um período de 48 horas, com condensador aço inox AISI 304, resfriado a uma $\mathrm{T}^{\mathbf{o}}$ de $-55^{\circ} \mathrm{C}$ é uma pressão de $-780 \mathrm{mmHg}$, por compressor hermético com gás refrigerante livre de CFC, ventilação forçada a ar, proteção hermética, sistema de drenagem com válvula de isolamento da câmara de secagem para o condensador evitando contaminação no momento da quebra do vácuo. Posteriormente, as amostras em cubo foram trituradas e homogeneizadas em almofariz de ágata por 30 minutos e peneirado. A amostra triturada e transformada em pó homogêneo foi acondicionada em frascos apropriados e etiquetados. Os cortes histológicos também foram etiquetados e armazenados em placa de petri, para realização dos mapas de distribuição elementar no Laboratório Nacional de Luz Síncrotron (LNLS), Campinas por Micro Fluorescência de Raios X ( $\mu$ XRF) e no Centro de Química e Meio Ambiente (CQMA), IPEN, USP, São Paulo por Espectrometria de fluorescência de raios $\mathrm{X}$ por dispersão de energia (EDXRF).
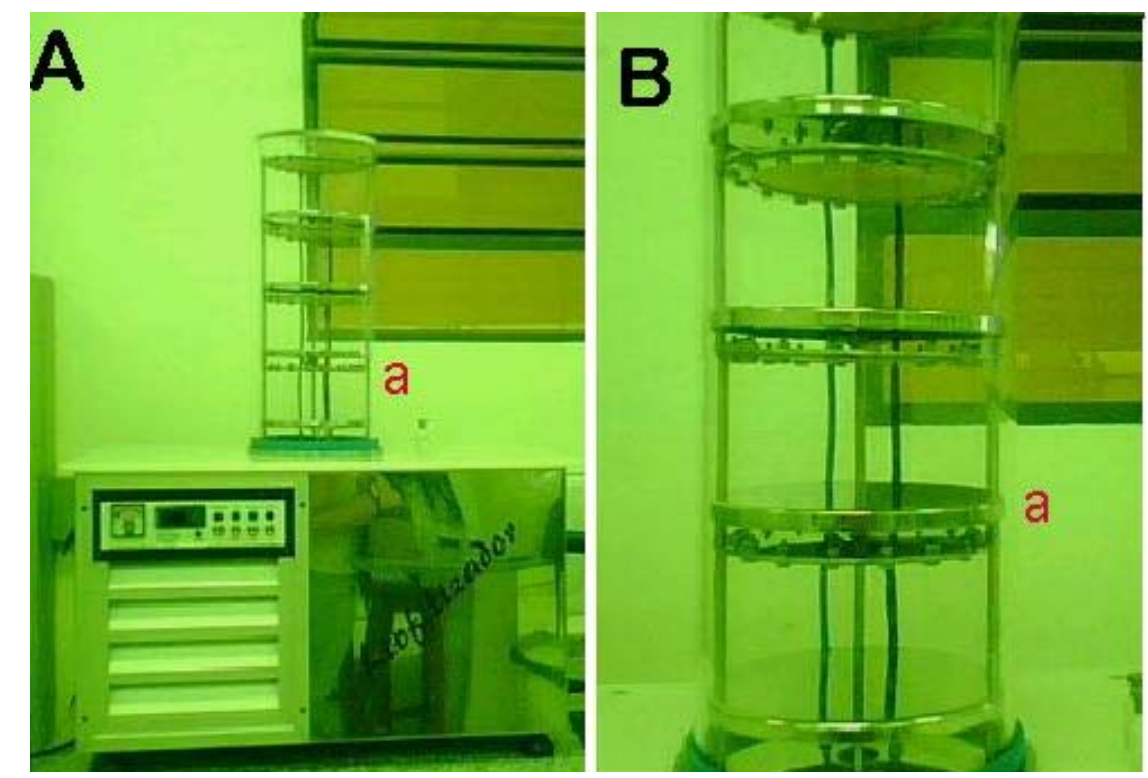

Figure 10 - A) Liofilizador Terroni LC 1500, B) Torre de liofilização à vácuo

O preparo das pastilhas foi realizado depois da liofilização. As amostras (Figura 11) posteriormente foram colocado aproximadamente $0,100 \mathrm{~m} \mathrm{~g}$ da amostra em pó no pastilhador (Perkin Elmer, 13mm DIE, modelo 4037 ) e a uma pressão $20 \mathrm{MPa}$ por 10 minutos para a obtenção de uma pastilha fina. 

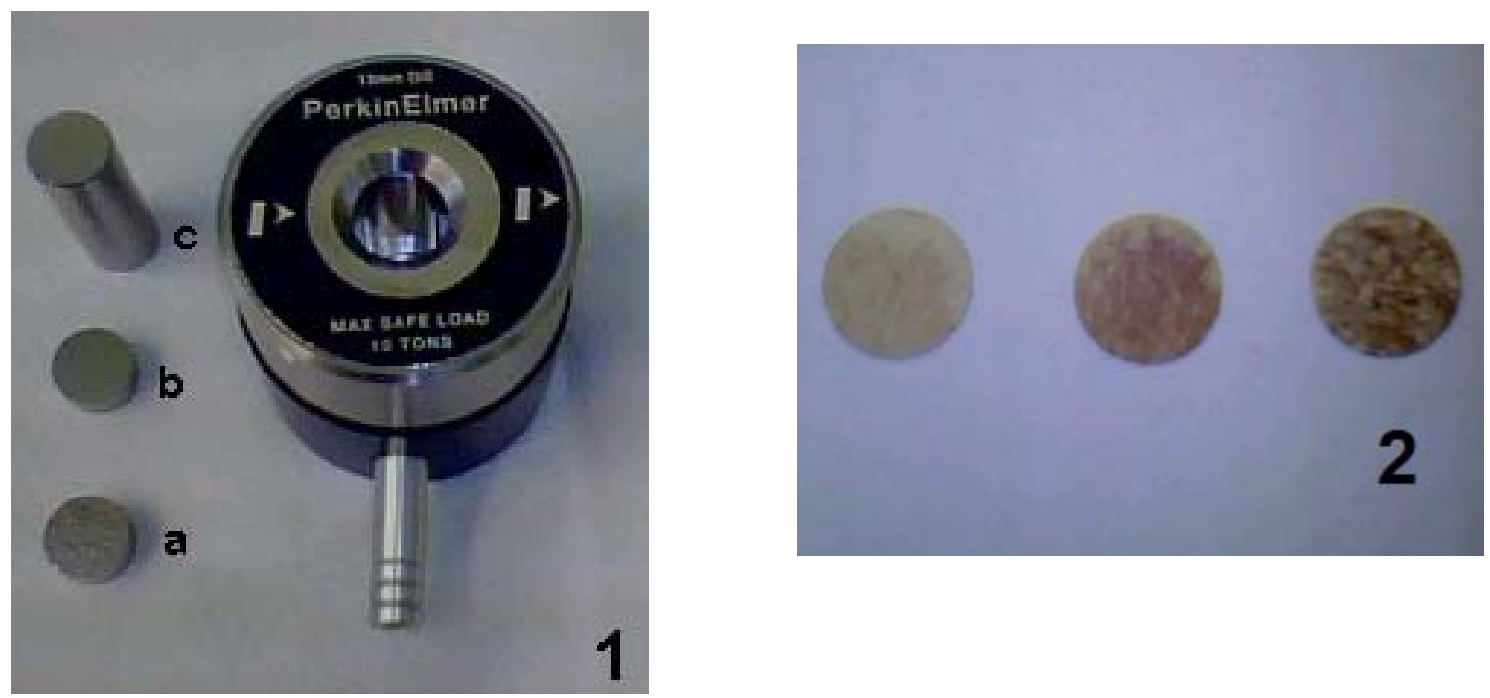

Figura 11 - (1) Pastilhador: a) base de apoio da amostra, b) base que fica sobre a amostra em pó, c) base de compressão para a prensa, (2) Pastilhas

Nas análises por fluorescência de raios $\mathrm{X}$ o preparo das amostras $\rightarrow$ é um fator muito importante, uma vez que se trata de uma técnica que atinge apenas a superfície da mesma, e não é exagerado dizer que os erros quantitativos nas análises por fluorescência de raios $\mathrm{X}$ devem ser atribuídos notadamente à preparação das amostras.

\subsection{FUNDAMENTOS TEÓRICOS SOBRE FLUORESCÊNCIA DE RAIOS X (XRF)}

A análise por fluorescência de raios $\mathrm{X}$ é um método quali-quantitativo baseado na medida das intensidades (número de raios $\mathrm{X}$ detectados por unidade de tempo) dos raios $\mathrm{X}$ característicos emitidos pelos elementos que constituem a amostra (BOUMANS; KLOCKENKÃMPER,1989). Os raios X emitidos por tubos de raios X, ou raios X ou gama por uma fonte radioativa, excitam os elementos que constituem que, por sua vez, emitem linhas espectrais com energias características do elemento e cujas intensidades estão relacionadas com a concentração do elemento na amostra.

Quando um elemento de uma amostra é excitado, este tende a ejetar os elétrons do interior dos níveis dos átomos, e como conseqüência disto, elétrons dos níveis mais afastados realizam um salto quântico para preencher a vacância (EISBERG,1979). Cada transição eletrônica constitui uma perda de energia para o elétron, e esta energia é emitida na forma de 
um fóton de raios X, de energia característica e bem definida para cada elemento. Assim, de modo resumido, a análise por fluorescência de raios $\mathrm{X}$ consiste de três fases: excitação dos elementos que constituem a amostra, dispersão dos raios $\mathrm{X}$ característicos emitidos pela amostra e detecção desses raios X (SERPA, 2006).

Algumas vezes, os raios $\mathrm{X}$ característicos interagem com elétrons do próprio átomo, e desse modo, ao invés de serem emitidos raios $\mathrm{X}$ característicos são emitidos elétrons, denominados elétrons Auger (Figura 12).
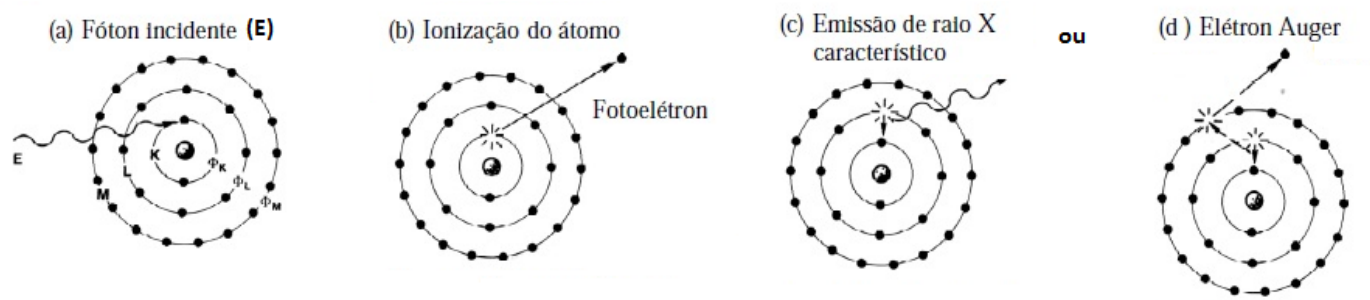

Figura 12 - Absorção fotoelétrica. (a) Fóton com energia $\mathrm{E}$ interage com o átomo. (b) A energia $\mathrm{E}$ do fóton incidente á absorvida pelo elétron da camada $\mathrm{K}$ e o elétron é ejetado da camada $\mathrm{L}$ como um fotoelétron, com energia cinética $\mathrm{E}^{\mathrm{fe}}(\mathrm{c})$ ocorre a emissão de um fóton

O resultado observado na tela do computador é um gráfico denominado "espectro de XRF” (Figura 13), que apresenta picos em determinados valores de energia. Através da consulta a uma tabela de energias, é possível, identificar os elementos químicos presentes na amostra que ao ser analisada através da XRF pode ser considerada um filme fino, uma vez que esta técnica necessita de diminutas quantidades de amostra para análise.

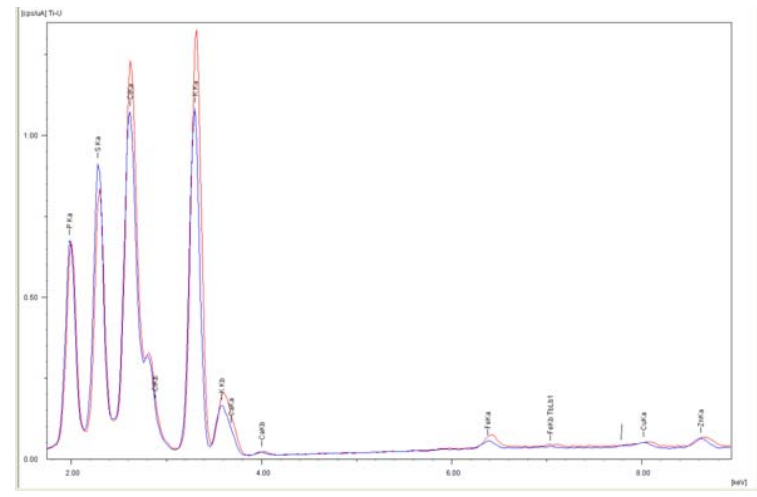

Figura 13- Exemplo de espectro EDXRF das amostras 


\subsubsection{Radiação Síncrotron}

Luz Síncrotron é a intensidade da radiação eletromagnética produzida por elétrons de alta energia num acelerador de partículas, esta radiação eletromagnética é emitida por partículas carregadas aceleradas em direção ao centro de uma órbita circular (HANSON; JONES; GORDON, 1990). A radiação Síncrotron é um milhão de vezes mais brilhante do que as fontes convencionais e, em termo de magnitude, 11 vezes mais brilhante raios $\mathrm{X}$ produzido por fonte convencional. Quando o feixe de raios X irradia a amostra origina uma interação com os constituintes atômicos da mesma com base em três processos principais: 0 efeito fotoelétrico, o efeito de dispersão elástica (Rayleigh) e o efeito inelástico (WINICK; DONIACH, 1980; LINDGREEN, 2000). Estas partículas, ao mudarem sua direção pela ação de dipolos magnéticos emitem uma intensa radiação eletromagnética, de alto brilho espectral, denominada radiação Síncrotron. Dipólo é um eletroímã que curva a trajetória do elétron no acelerador circular.

O acelerador do LNLS possui doze dipólos, cada um deles curva a trajetória dos elétrons em 30 graus. A luz Síncrotron abrange uma ampla faixa do espectro eletromagnético conforme pode ser visualizado na figura 14 raios-X, luz ultravioleta e infravermelha, além da luz visível, que sensibiliza o olho humano, são emitidas pela fonte. Foi através desta luz que diversas pesquisas foram desenvolvidas, através do qual foram constatadas novas propriedades física, química e biológica existentes nos átomos e moléculas. A circulação de corrente em anéis de armazenamento de alta energia emite feixes pulsados de luz tipicamente polarizada. A luz Síncrotron possibilita alcançar limites de detecção mais baixos do que se utilizando-se um tubo de Raios X de alta potência.

A Luz Síncrotron tem grandes aplicações científicas na Biologia, Medicina, Física, Engenharia e Geociências, através da técnica denominada Micro-fluorescência de raios X $(\mu \mathrm{XRF})$, com uma microssonda de raios $\mathrm{X}$ que permite atingir uma resolução espacial micrométrica intalada no Laboratório Nacional de Luz Síncrotron (LNLS) em Campinas, SP.

A linha de luz para análise por fluorescência de raios X no LNLS é equipada com um capilar cônico ultrafino, que condensa o feixe de luz branca de $0,5 \mathrm{~mm}$ por $0,5 \mathrm{~mm}$. É utilizado um feixe branco monocromático. Também fazem parte da mesma uma janela de berílio, para isolar o vácuo da linha, um cristal monocromador channel-cut e um conjunto de fendas motorizadas controladas por computador, para limitar o feixe de luz. Detectores por 
dispersão de energia $\mathrm{Si}(\mathrm{Li})$ e HP (Ge) integram o sistema de detecção da linha de luz (PEREZ et al., 1999).

\subsubsection{Micro-fluorescência de Raios-X ( $\mu$ XRF)}

A $\mu$ XRF é uma sub-variante microanalítica da fluorescência de raios $X$ por dispersão em energia (EDXRF), possibilitando realizar mapeamento químico da amostra e verificando sua homogeneidade. Está técnica faz uso de análise multielementar que é altamente sensível sendo capaz de mapear a área desejada para estudo. Vários trabalhos foram desenvolvidos indicando a importante aplicabilidade da técnica em tecidos biológicos (BERTIN, 1979).

A grande vantagem desta técnica é que o feixe primário pode ser focalizado em uma pequena região da amostra, permitindo que pequenas características estruturais sejam analisadas, baixa dispersão de energia e praticamente nenhum dano térmico na amostra a ser analisada, logo não há perda de elementos voláteis; as amostras podem ser analisadas sem a necessidade de vácuo e baixo sinal de fundo resultando em melhores limites de detecção.

A $\mu$ XRF é capaz de produzir mapas elementares bidimensional, a geometria utilizada (em geral $45^{\circ} / 45^{\circ}$ ) com as dimensões bastante reduzidas do feixe incidente (da ordem de $\mu \mathrm{m})$.

Atráves da aplicação da $\mu$ XRF pode-se obter três tipos de informações: Informação pontual do espectro, fornece uma rápida comparação de diferentes materiais, conseguindo analisar especificamente uma determinada região, tem a capacidade de analisar pequenas particulas sem necessidade de preparo da amostra. Perfis, são uma série de pontos espectriais, em geral, transverso a amostra. A análise fornece informações sobre a homogeneidade da amostra, são utilizados para efetuar medidas de distribuição elementar. Mapas elementares, é uma combinação de multiplas linhas é realizado a análise da composição de uma superfície. A presença em maior ou menor ou auséncia ou a associação elementar amostra é representada através de uma escala de variações de cores (HAVRILLA, 1997). Para obter um mapeamento elementar, e gerado um mapa indivdual da área de interesse, e gerado um mapa individual da área de interesse para cada elemento, que possui um espectro caracteristico. Para cada mapa, são necessário no mínimo 1000 pixels, com um tempo de medida de 10 s por elemento, dependendo do tamanho da amostra e das dimensões dos feixes, totalizando um tempo total de 3-5 horas para cada mapeamento (SERPA, 2006). 
As amostras foram analisadas no Laboratório Nacional de Luz Síncrotron onde o equipamento de Microfluorescência de Raios-X (Figura 14).

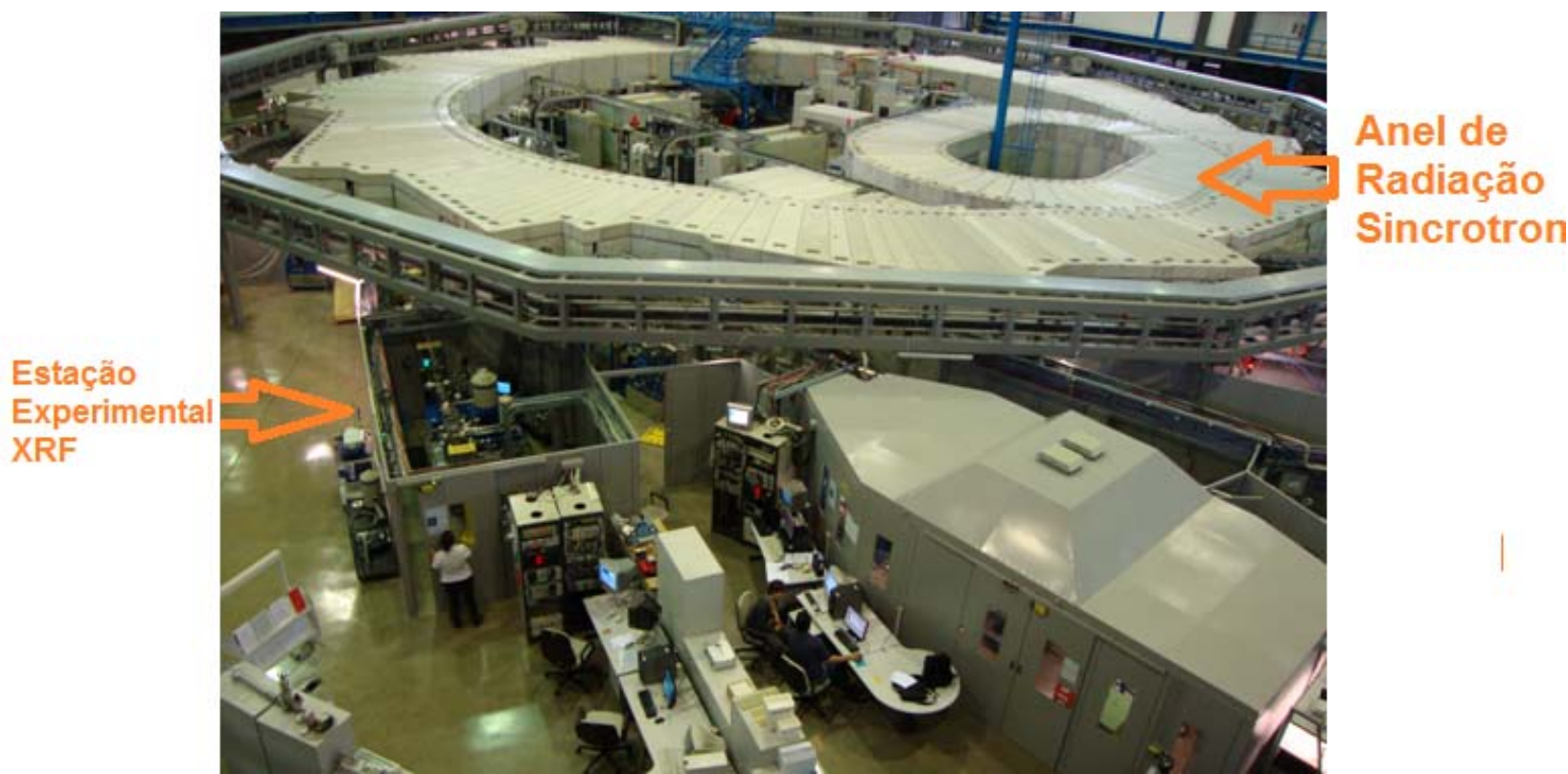

Figura 14 - Vista Geral do anel de armazenamento e da estação experimental D09B-XRF do Laboratório de Luz Síncrotron com a instrumentação

Algumas características do equipamento são listadas abaixo: a fonte de excitação corresponde a um imã defletor $\mathrm{D} 09 \mathrm{~B}\left(15^{\circ}\right), \sigma y=0.222 \mathrm{~mm}$ com fluxo na amostra correspondente a $4 \times 10^{9}$ fótons $/ \mathrm{s}$ a $8 \mathrm{keV}$. Um monocromador channel-cut e cristais de $\mathrm{Si}$ (111) $\quad\left(2 \mathrm{~d}=6.217 \quad \mathrm{~A}^{\mathrm{o}}\right): \quad 4-14 \quad \mathrm{keV} \quad(\mathrm{E} / \mathrm{DE}=2800), \quad \operatorname{Si}(220) \quad\left(2 \mathrm{~d}=3.84 \quad \mathrm{~A}^{\mathrm{o}}\right): \quad 5-23 \quad \mathrm{keV}$ $(\mathrm{E} / \mathrm{DE}=15000)$ disponíveis para uso.

O sistema possui um detectores de estado sólido de Ge-hiperpuro (resolução de 150 eV) e Si(Li) (resolução de $165 \mathrm{eV}$ ), assim como fotodiodos e câmeras de ionização.

O tempo de medida das amostras e dos padrões correspondeu a 100s e os espectros de raios $\mathrm{X}$ característicos obtidos foram analisados através do Software Sistema de Análise Quantitativo de raios X (AXIL - IAEA, 1978), distribuído pela Agência Internacional de Energia Atômica (AIEA) obtendo as intensidades dos raios $\mathrm{X}$ para cada elemento. 
As amostras foram posicionadas no plano de imagem com uma acuraria de 0,5 $\mu \mathrm{m}$ com os eixos controlados por motor de passo. O suporte foi posicionado a $45^{\circ}$ em relação e ao detector ao feixe incidente, em um posicionamento também conhecido como geometria $45^{\circ} / 45^{\circ}$.
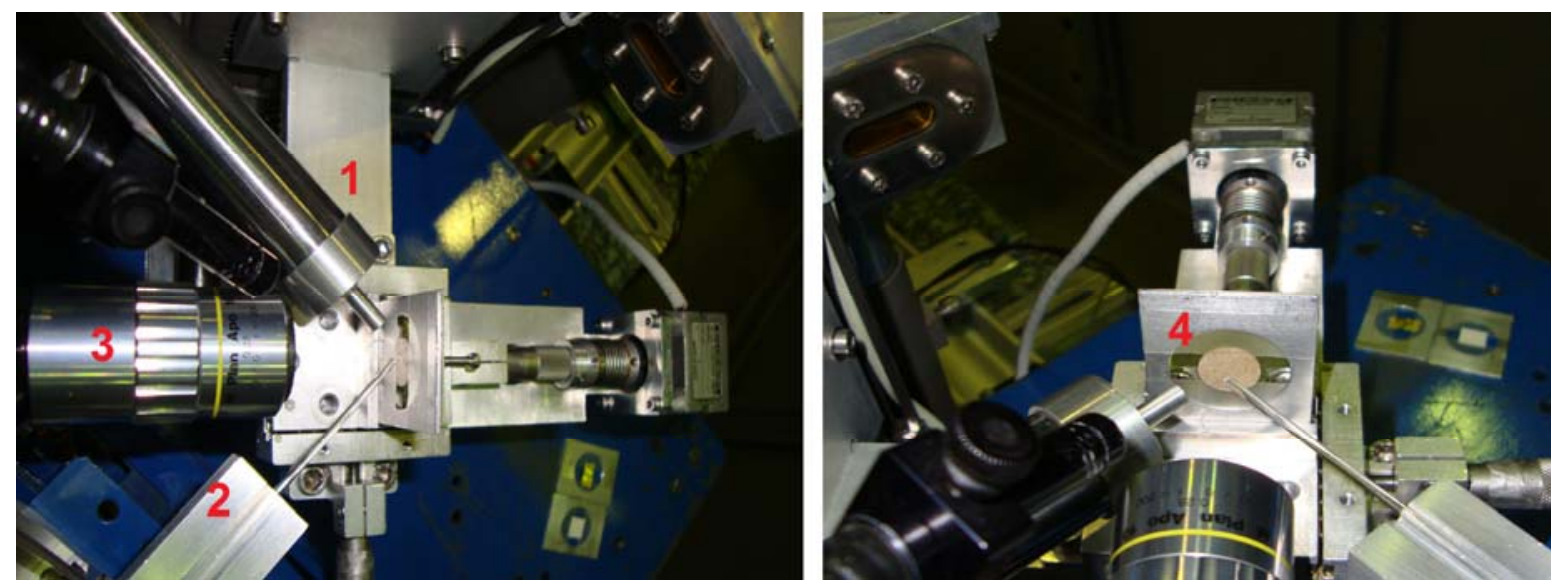

Figura 15 - Arranjo experimental da microfluorência de raios X, (1) colimador (2) capilar (3) detector (4) porta amostra

Utilizou-se um feixe branco de radiação para excitar as amostras, com dimensões de $500 \mu \mathrm{m}$ tanto na horizontal quanto na vertical, obtidos através de um sistema convencional de colimação com fendas. As amostras mapeadas, então, com passos de $30 \mu \mathrm{m}(\mathrm{H})$ por 30 $\mu \mathrm{m}(\mathrm{V})$, ou seja, a cada $30 \mu \mathrm{m}$ tanto na horizontal quanto na vertical correspondendo a um pixel. O tempo de contagem para cada pixel foi de 10 segundos.

Os Raios X característico produzidos em cada pixel foram medidos por um detector de $\mathrm{Si}(\mathrm{Li})$ com resolução de $165 \mathrm{eV}$ em $5,9 \mathrm{KeV}$ posicionado a $90^{\circ}$ em relação ao feixe incidente, no plano orbital dos elétrons, com o intuito de minimizar o sinal de fundo espectral, uma vez que o número de raios $\mathrm{X}$ espalhados no detector é minimizado nessa posição (HANSON; JONES; GORDON, 1987).

Os mapas bidimensionais foram obtidos após a normalização das intensidades dos raios $\mathrm{X}$ característicos pelo valor da câmara de ionização, que mede a intensidade do fluxo de raio $\mathrm{X}$. 


\subsection{FUNDAMENTOS TEÓRICOS SOBRE FLUORESCÊNCIA DE RAIOS X POR DISPERSÃO DE ENERGIA (EDXRF)}

A fluorescência de raios X por dispersão de energia (EDXRF) mais prática e menos dispendiosa, permitindo a determinação da concentração de vários elementos de modo simultaneamente, sem a necessidade de destruição da amostra.

Na EDXRF os raios X são selecionados através dos pulsos eletrônicos produzidos em um detector, estes pulsos são diretamente proporcionais às energias dos raios X. Os raios X secundários são emitidos simultaneamente no detector, sem que haja prévia dos diversos comprimentos de onda que informam a composição química da amostra em estudo. Dessa forma, a análise simultânea é necessária, é viável através da utilização detectores semicondutores de $\mathrm{Si}(\mathrm{Li})$. A geometria é simplificada, não necessitando de cristais para discriminar a radiação secundárias, a EDXRF, utiliza excitação seletiva, obtida por meio de filtros, por exemplo, a detecção simultânea de todos os comprimentos de onda de interesse.

Os detectores semicondutores de $\mathrm{Si}(\mathrm{Li})$ são empregado na detecção de raios $\mathrm{X}$ de energia entre 1 a $25 \mathrm{KeV}$, ou seja, raios $\mathrm{X} \mathrm{K}$ (transição camada $\mathrm{L} \rightarrow \mathrm{K}$ ) emitidos por elementos de numero atômico na faixa de $11(\mathrm{Na})$ a $50(\mathrm{Sn})$ e raios X L (transição $\mathrm{M} \rightarrow \mathrm{L}$ ) dos elementos pesados, na faixa de $31(\mathrm{Ga})$ a $92(\mathrm{U})$. Para os raios X K de alta energia, emitidos pelos elementos de número atômico alto $(Z>50)$, é mais aconselhado o uso dos detectores de $\mathrm{Ge}(\mathrm{Li})$ e Ge hiperpuro, em virtude à sua maior eficiência de detecção nesta região.

EDXRF e composta basicamente pela fonte geradora de radiação eletromagnética, filtros para radiação primárias, a irradiação da amostra com conseqüente geração de raios $\mathrm{X}$ secundário incidindo diretamente sobre a superfície do detector, seguido pelo sistema eletrônico e de interpretação de dados.

$\mathrm{Na}$ técnica de EDXRF, clássica o feixe primário incide sobre a amostra em um ângulo cerca de $40^{\circ} \mathrm{Em}$ virtude do baixo angulo de incidência, o feixe primário e praticamente refletido de forma integral, sendo que apenas uma pequena fração de energia sobre refração. 


\subsubsection{Preparação de Amostra EDXRF}

As amostras foram analisadas no Instituto de Pesquisas Energéticas e Nucleares (IPEN) no Centro de Química e Meio Ambiente (CQMA). Posterior ao processo descrito no item 4.4.1.1, o tamanho dos grãos do pó foram uniformizados a granulométrica do pó foi uniformizada por meio de peneira de 200 mesh. As amostras em pó foram adequadamente acondicionadas em frascos de polipropileno (Figura 16) e depois colocadas em porta amostra com filme de Mylar (filme de poliéster, $5 \mu \mathrm{m}$ de espessura).

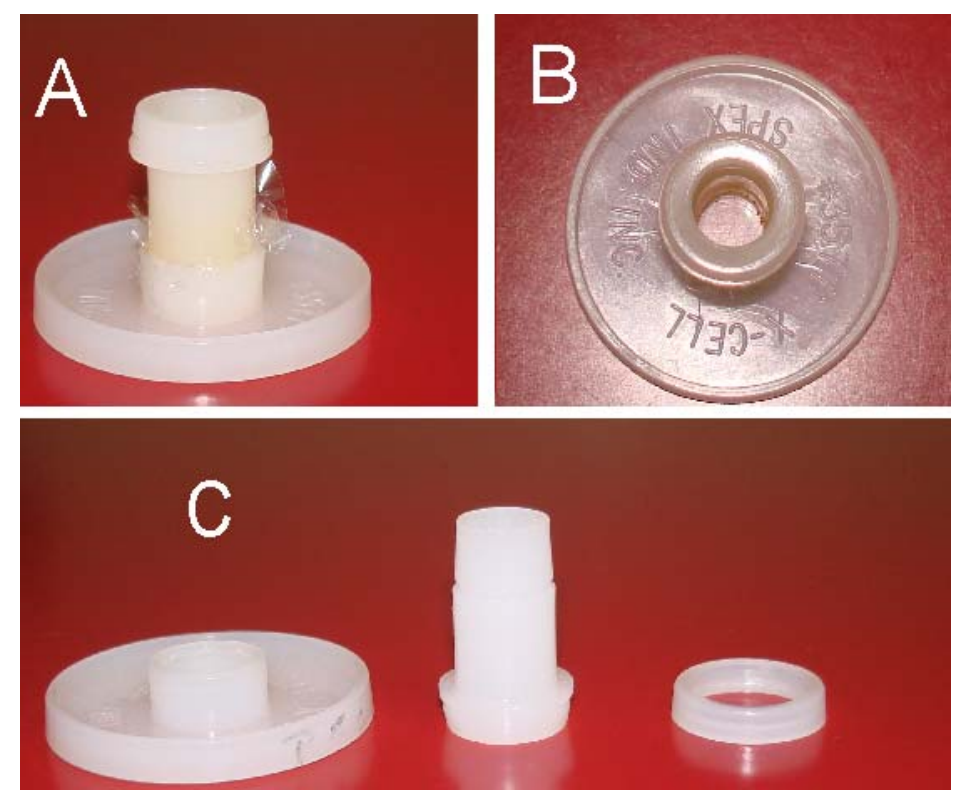

Figura 16 - Posicionamento da amostra para medida (A) Porta amostra lacrado com papel filme, (B) Vista do interior do porta amostra, (C) partes individuais do porta amostra

\subsubsection{Método de Parâmetros Fundamentais}

A determinação quantitativa dos elementos efetivou-se por meio do método de parâmetros fundamentais. Este método baseia-se na obtenção de uma curva de sensibilidade específica para cada elemento que é calculado a partir de uma relação das intensidades fluorescentes experimentais e teóricas. As intensidades teóricas são calculadas com base em valores nominais de padrões ou materiais de referências. As intensidades fluorescentes experimentais das radiações características dependem das condições instrumentais de medida estabelecida no espectrômetro. 
A determinação das concentrações dos elementos traço foi efetivada utilizando a técnica de Espectroscopia EDXRF, em equipamento Shimadzu EDX-720 (Figura 17) com tubo de raios X: Rh (3.0kW); Excitação: $15 \mathrm{kV}$ para Si Ka e $50 \mathrm{kV}$ para UL $\alpha$; corrente: 1 mA, máximo; Colimador: $10 \mathrm{~mm}$; Detector: $\mathrm{Si}$ (Li) refrigerado com líquido $\mathrm{N}_{2}$; tempo de medição: 100 s para Si Ka e 50 s para UL $\alpha$, com filtro de Ag.
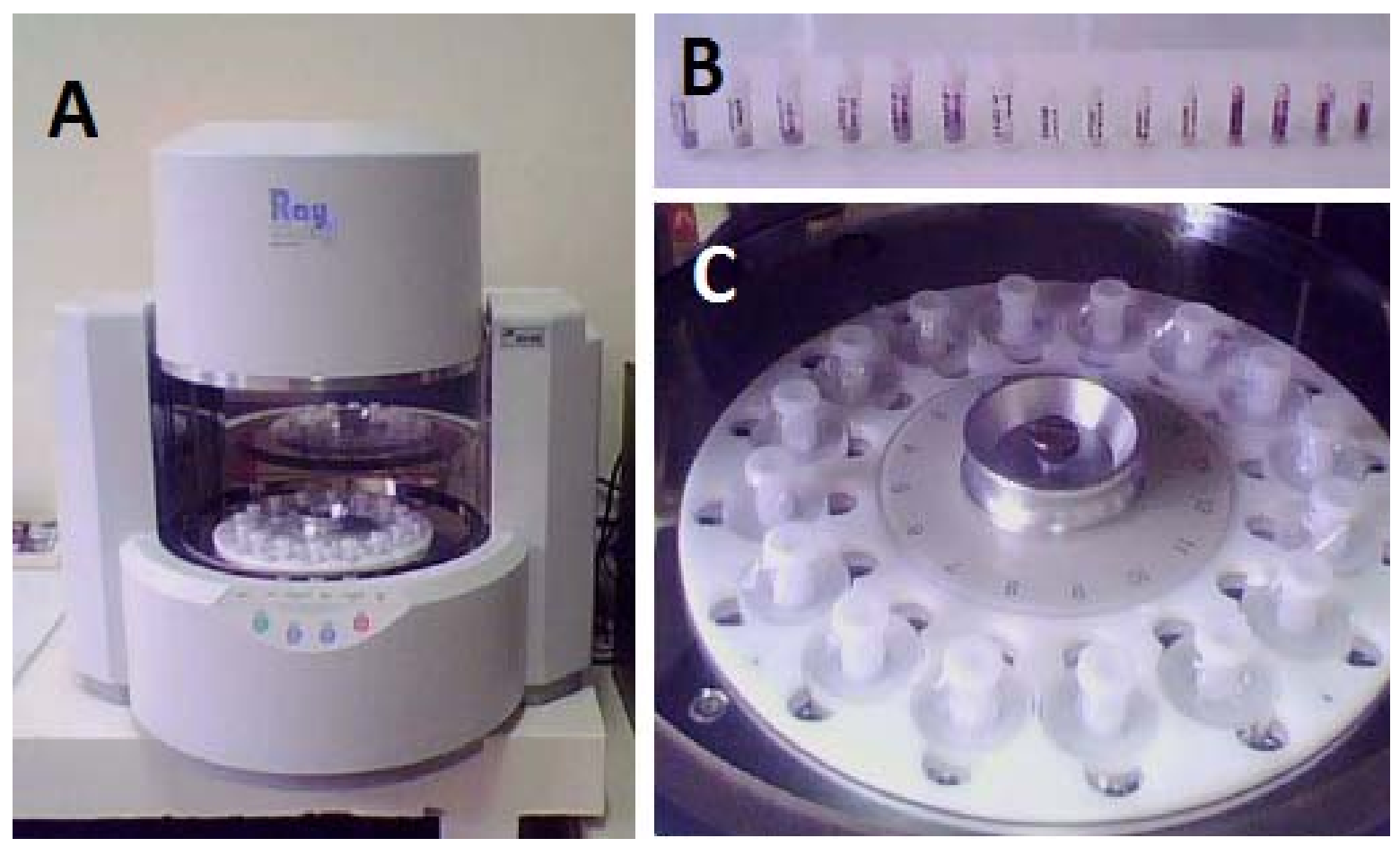

Figura 17 - (A) Espectrômetro de fluorescência de raios X por dispersão de energia (EDXRF), (B)Frascos de polietileno com amostra em pó, (C) Suporte para os porta amostra para análise

Para a determinação dos elementos $\mathrm{Na}, \mathrm{Mg}, \mathrm{P}, \mathrm{Cl}, \mathrm{K}, \mathrm{Ca}, \mathrm{Mn}, \mathrm{Fe}, \mathrm{Co}, \mathrm{Cu}, \mathrm{Zn}, \mathrm{Se}$ e Mo as curvas de calibração foram construídas por meio de ajuste pelo método de regressão linear utilizando-se os materiais de referência certificado, NIST- 1577b - fígado bovino (ANEXO A). As correlações de efeito matriz foram realizadas por meio de métodos de parâmetros fundamentais utilizando-se software acoplado ao equipamento.

\section{7 ANÁLISE ESTATÍSTICA}

Foi realizada uma análise quantitativa, utilizando métodos de parâmetros fundamentais, utilizando ensaio direto não destrutivo. Analisamos primeiramente se existia 
distinção entre regiões do placentônio, em um mesmo tratamento (clone ou controle) e período gestacional (90, 135 ou 225 dias) através de uma análise de variância (ANOVA), assumindo o erro do tipo I de 5\% (significativo com $\alpha<0.05$ ). Encontrado significância na ANOVA, realizamos o teste de Tukey HSD, comparando os valores médios encontrados para os diferentes elementos químicos (macro e micronutrientes), agrupando aqueles valores que os médios não foram maiores que a diferença mínima significativa.

Para saber se as variações das médias são estatisticamente significativas, usou-se o test-t Student, cuja finalidade e estabelecer um critério que permita distinguir diferenças reais e amostrais.

Comparamos através do teste-t de Student, os valores médios dos elementos químicos em uma mesma região e período gestacional apresentados para GCO e GCL verificamos por meio do teste ANOVA se houve alterações significativas dos valores médios dos elementos químicos entre os diferentes períodos gestacionais em uma mesma região do placentônio. Encontrando diferenças significativas entre os períodos gestacionais, realizamos o teste pos hoc de Tukey HSD. Para todas as análises estatísticas utilizamos a linguagem R versão 2.11 ( $R$ core team 2010).

Com base nos dados $\alpha$-value foi possível construir os gráficos de Box-plot, relacionando a concentração média de cada elemento entre os grupos de CO e CL. 


\section{RESULTADOS E DISCUSSÃO}

A exatidão e a precisão dos resultados das análises das amostras foram verificadas por meio da análise do material de referência certificado NIST $1577 \mathrm{~b}$.

Nas Tabelas 1 e 2 são apresentados os resultados das análises do material de referência e a média encontrada na amostra de fígado bovino. O material da análise do material de referência apresentou-se adequado para os elementos $\mathrm{Ca}, \mathrm{Mn}, \mathrm{Fe}, \mathrm{Cu}, \mathrm{Zn}, \mathrm{Se}$, Mo. As medidas foram realizadas em tréplicas.

Tabela 1 - Concentração elementar $\left(\mu \mathrm{g} \mathrm{g}^{-1}\right)$ para o material de referência fígado bovino $1577 \mathrm{~b}$, Instituto de Pesquisas Energéticas e Nucleares (IPEN), São Paulo, 2009 a 2010

\begin{tabular}{lcl}
\hline Elementos & Valor Obtido $\left(\mu \mathrm{g} \mathrm{g}^{-1}\right)$ & Valor certificado $\left(\mu \mathrm{g} \mathrm{g}^{-1}\right)$ \\
\hline $\mathrm{Mg}$ & $318,47 \pm 123,27$ & $601 \pm 28$ \\
$\mathrm{Ca}$ & $85,01 \pm 1,57$ & $116 \pm 4$ \\
$\mathrm{Mn}$ & $8,79 \pm 1,26$ & $10,5 \pm 1,7$ \\
$\mathrm{Fe}$ & $130,08 \pm 1,75$ & $184 \pm 1,5$ \\
$\mathrm{Co}$ & $1,00 \pm 0,12$ & $0,25 \pm 1$ \\
$\mathrm{Cu}$ & $125,04 \pm 1,31$ & $160 \pm 8$ \\
$\mathrm{Zn}$ & $113,01 \pm 1,27$ & $127 \pm 16$ \\
$\mathrm{Se}$ & $1,00 \pm 0,20$ & $0,73 \pm 0,1$ \\
$\mathrm{Mo}$ & $2,21 \pm 1,48$ & $3,5 \pm 0,3$ \\
\hline
\end{tabular}

Tabela 2 - Concentração elementar (\%) para o material de referência fígado bovino $1577 \mathrm{~b}$, Instituto de Pesquisas Energéticas e Nucleares (IPEN), São Paulo, 2009 a 2010

\begin{tabular}{lll}
\hline Elementos & Valor Obtido (\%) & Valor certificado (\%) \\
\hline $\mathrm{Na}$ & $0,227 \pm 0,021$ & $0,242 \pm 0,006$ \\
$\mathrm{P}$ & $0,703 \pm 0,002$ & $1,10 \pm 0,03$ \\
$\mathrm{Cl}$ & $0,258 \pm 0,001$ & $0,278 \pm 0,006$ \\
$\mathrm{~K}$ & $0,710 \pm 0,002$ & $0,994 \pm 0,002$ \\
\hline
\end{tabular}


Os resultados obtidos na análise dos materiais de referência mostram um erro relativo (ER) menor que $10 \%$ para a maioria dos elementos analisadas, o que indica boa exatidão e um desvio padrão relativo (DPR) abaixo de $10 \%$, indicando boa precisão do método.

\subsection{ANÁLISE QUANTITATIVA POR EDXRF}

A avaliação das concentrações médias permitiu executar uma pré-análise, fornecendo uma estimativa das alterações químicas em macroescala para os tecidos oriundo dos animais não manipulados (GCO) e clonados (GCL). As análises foram conduzidas para determinar a variação na concentração dos elementos constituintes e traço em regiões PLM, PLC e IPL e a existência de variação da concentração de elementos entre regiões distintas. Os grupos foram determinados de acordo com a idade gestacional: Grupo I - 90 dias, Grupo II - 135 dias, Grupo III - 225 dias de gestação.

\subsubsection{Sódio $(\mathrm{Na})$}

Avaliou-se o elemento $\mathrm{Na}$ em diferentes regiões da placenta $\mathrm{CO}$, segundo o teste ANOVA, não mostraram diferenças significativas entre as regiões amostradas com 90 $\left(F_{2,3}=0.98, \alpha=0.47\right), 135\left(F_{2}=0.097, \alpha=0.909\right)$ e 225 dias $\left(F_{2,3}=3.5177, \alpha=0.097\right)$ para as porcentagens de $\mathrm{Na}$, quando assumimos $5 \%$ para o erro do tipo I (Tabela 3 ).

As regiões placentárias no GCL, segundo o teste ANOVA, não mostraram diferenças significativas entre as regiões amostradas com $90\left(\mathrm{~F}_{2,3}=1.925, \alpha=0.226\right), 135\left(\mathrm{~F}_{2,3}=0.217\right.$, $\alpha=0.8102)$ e $225 \operatorname{dias}\left(F_{2,3}=5.173, \alpha=0.1066\right)$.

O GCL apresentou maior concentração de Na na região IPL com 90 dias de gestação, segundo o teste t, houve diferença significativa no grupo I entre o GCL e GCO, GCL apresentaram uma concentração de 55,18\% a mais que o GCO, em seus valores percentuais de sódio $\alpha<0.05$ (Figura 18). 
O valor de sódio só variou no GCL na região PLM amostrados aos 90 dias ( $\mathrm{t}=6.234$, $\alpha<0.05$ ), sendo encontrados valores percentuais menores no GCL do que nos GCO. Nas outras regiões e períodos gestacionais, o GCL e GCO não apresentaram valores significativamente distintos (Tabela 3).

O GCL apresentou na região IPL uma diminuição na concentração elementar com o avançar do período gestacional, já o GCO apresentou o comportamento inverso, com aumento na concentração elementar (Figura 18). Na região PLM segundo a figura 19. A concentração de $\mathrm{Na}$ diminui com o avançar do período gestacional, para o GCL ocorreu o mesmo comportamento apenas para os períodos gestacionais de 135 e 225 dias, o período de 90 dias apresentou uma concentração média inferior que o GCO, em seus valores percentuais de $\mathrm{Na} \alpha<0,05$. A região PLC não apresentou variação na concentração entre as regiões amostradas.

Tabela 3 - Valores de sódio (Na) (\%) para GCO e GCL para as regiões PLC, PLM e IPL Formação dos grupos segundo o teste de Tukey HSD (ANOVA, $\alpha<0.05$ ); ns: não significativo $(\alpha>0.05)$. Valor do teste t para GCO e GCL , localizados na mesma região do placentônio e mesmo período gestacional (90, 135 ou 225 dias), Instituto de Pesquisas Energéticas e Nucleares (IPEN), São Paulo, 2009 a 2010

\begin{tabular}{lllllll}
\hline & & & & & \multicolumn{2}{l}{} \\
Região & dias & GCO & grupos & GCL & grupos & t \\
\hline IPL & 90 & $0.355 \% \pm 0.049$ & $\mathrm{~ns}$ & $0.6433 \% \pm 0.255$ & $\mathrm{~ns}$ & $1.9066^{*}$ \\
PLC & & $0.41 \% \pm 0$ & & $0.39 \% \pm 0.0436$ & & 0.7947 \\
PLM & $0.597 \% \pm 0.007$ & & $0.355 \% \pm 0.066$ & & $6.234^{*}$ \\
\hline IPL & 135 & $0.453 \% \pm 0.109$ & $\mathrm{~ns}$ & $0.43 \% \pm 0.1414$ & $\mathrm{~ns}$ & -0.1971 \\
PLC & $0.42 \% \pm 0.085$ & & $0.4025 \% \pm 0.043$ & & -0.3256 \\
PLM & $0.43 \% \pm 0.089$ & & $0.43 \% \pm 0.036$ & & 0 \\
\hline IPL & 225 & $0.425 \% \pm 0.076$ & $\mathrm{~ns}$ & $0.447 \% \pm 0.035$ & $\mathrm{~ns}$ & -0.4302 \\
PLC & $0.3783 \% \pm 0.023$ & & $0.3033 \% \pm 0.007$ & & 0.8193 \\
PLM & $0.367 \% \pm 0.083$ & & $0.385 \% \pm 0.049$ & & 0.4765 \\
\hline
\end{tabular}

Níveis de significância: *: $\alpha<0.05$; ** $\alpha<0.01 ; * * *: \alpha<0.001$

A principal função do Na é a manutenção da pressão osmótica, é de importância vital para manter o equilíbrio hidroeletrolítico entre os compartimentos extra e intracelular, manter o equilíbrio ácido-base, e manter o organismo dentro da faixa de $\mathrm{pH}$. A menor concentração intracelular é mantida pelas bombas de sódio-potássio e de magnésio- ATPase. Os filhotes apresentam quase o dobro de $\mathrm{Na}$ do que os adultos porque possuem relativamente 
maiores quantidades de tecidos conjuntivos, cartilagem e líquido extracelular é relativamente menores massas musculares, cujas células possuem pequenas quantidades de sódio, esse é um dos fatores que levam filhotes rapidamente às desidratações. Essa hipótese confirma os resultados dessa pesquisa quando verifica-se que a placenta apresenta uma diminuição nos valores da concentração de Na com a avançar do período gestacional (PEREIRA, 2005).

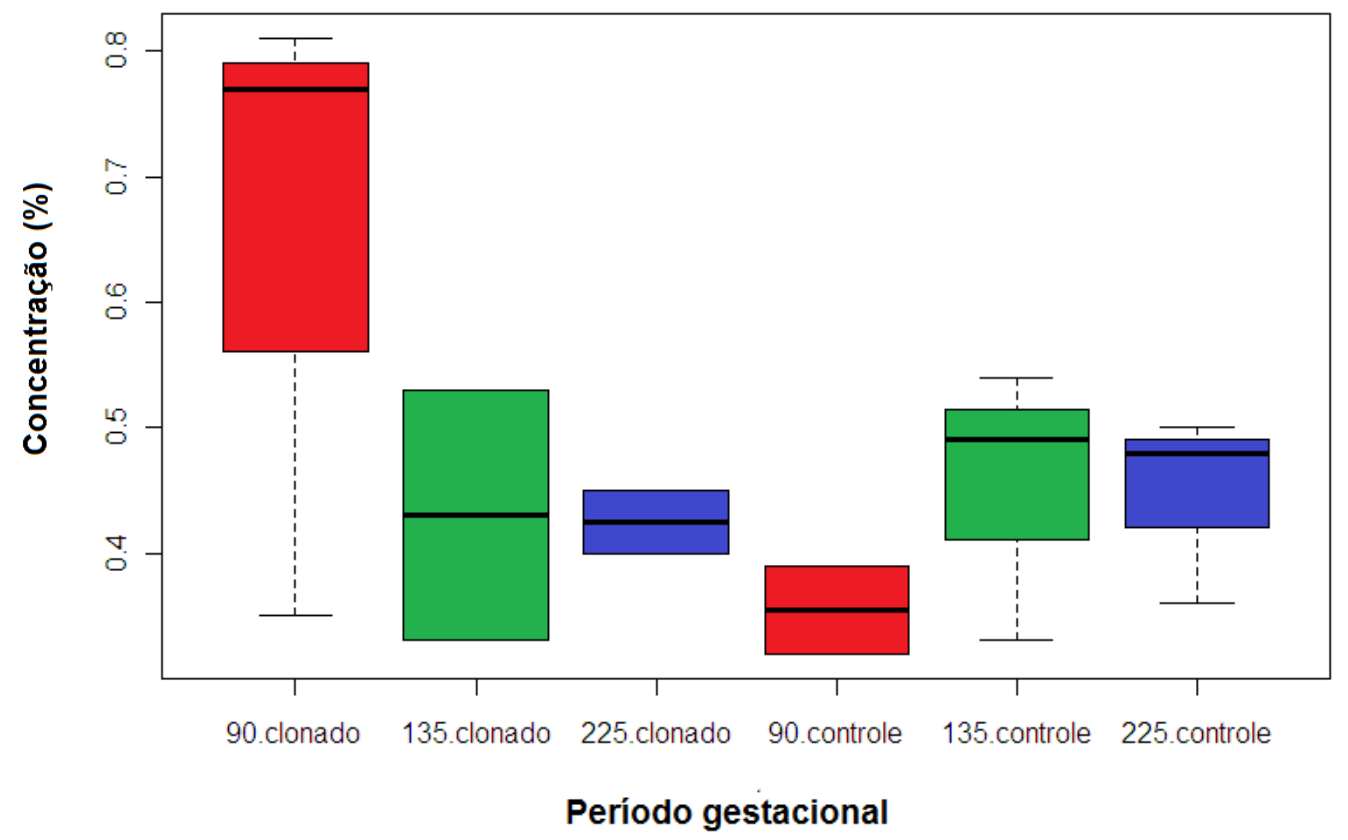

Figura 18 - Diagrama em caixa (boxplot) da concentração de sódio (\%) para a região IPL para todos os grupos e períodos gestacionais

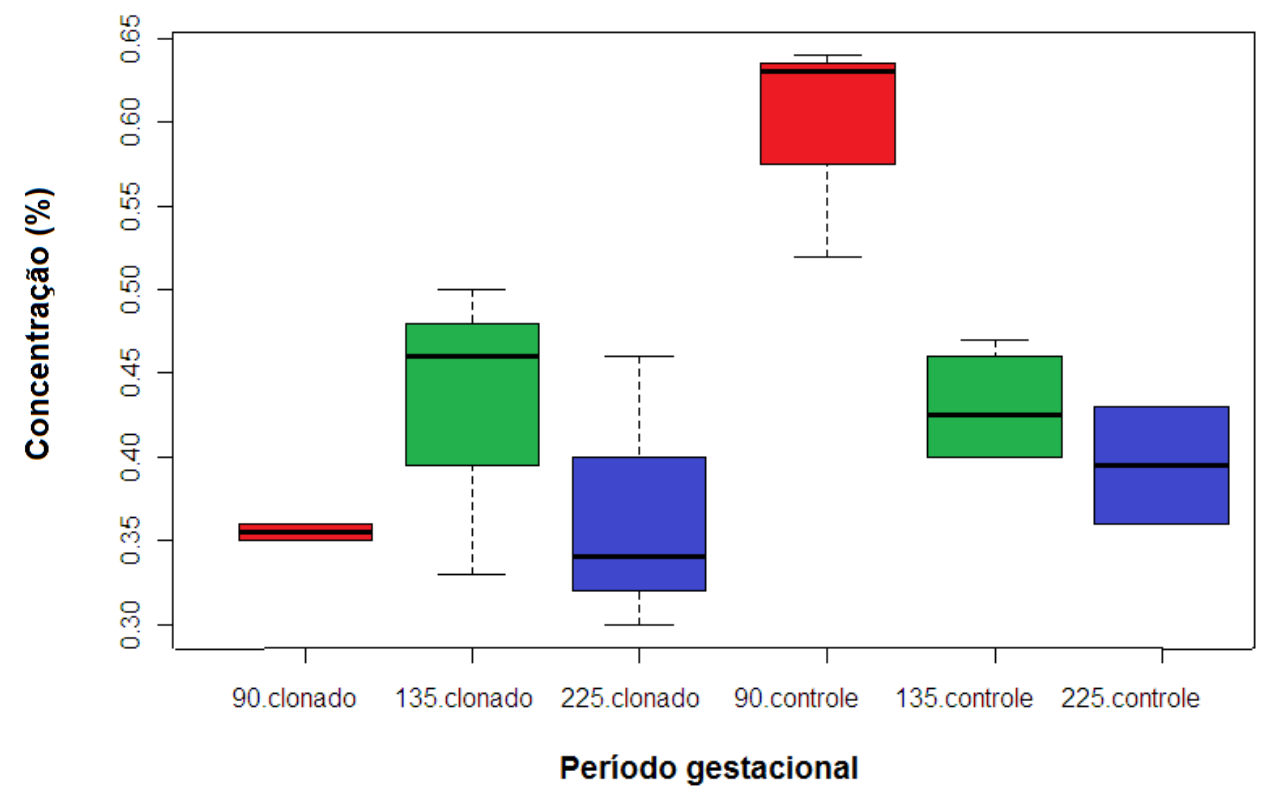

Figura 19 - Diagrama em caixa (boxplot) da concentração de sódio (\%) para a região PLM para todos os grupos e períodos gestacionais 
Avaliou-se o elemento Mg nas diferentes fases gestacionais para o GCO. Aplicandose o teste ANOVA, verificou-se que as amostras correspondente as fases 90 e 135 dias não apresentaram diferenças significativas entre as amostras de $90\left(\mathrm{~F}_{2,3}=1.2304, \alpha=0.4072\right)$ e 135 $\operatorname{dias}\left(\mathrm{F}_{2,3}=0.756, \alpha=0.5096\right)$. No entanto, a concentração desse elemento para a fase 225 dias apresentou diferenças significativas nas regiões PLC e IPL, sendo que a região PLM (Figura 21) não apresentou diferença significativa com os outros dois locais de amostragem. Assim sendo, a região PLC apresenta significativamente mais magnésio que a região IPL (Tabela $4)$.

Tabela 4 - Valores de magnésio $(\mathrm{Mg})\left(\mu \mathrm{g} \mathrm{g}^{-1}\right)$ para GCO e GCL para as regiões PLC, PLM e IPL Formação dos grupos segundo o teste de Tukey HSD (ANOVA, $\alpha<0.05$ ); ns: não significativo $(\alpha>0.05)$. Valor do teste t para GCO e GCL, localizados na mesma região do placentônio e mesmo período gestacional (90, 135 ou 225 dias), Instituto de Pesquisas Energéticas e Nucleares (IPEN), São Paulo, 2009 a 2010

\begin{tabular}{lllllll} 
Região dias & Controle & \multicolumn{2}{l}{ grupos } & Clonados & \multicolumn{2}{c}{ grupos } \\
\hline IPL & 90 & $302.24 \pm 7.594$ & $\mathrm{~ns}$ & $568.447 \pm 229.504$ & $\mathrm{~ns}$ & 2.0074 \\
PLC & & $947.15 \pm 344.276$ & & $500.76 \pm 458.479$ & & 1.2413 \\
PLM & $610.24 \pm 17.021$ & & $1071.82 \pm 84.677$ & & $9.1675^{* *}$ \\
\hline IPL & 135 & $535.047 \pm 201.336$ & $\mathrm{~ns}$ & $473.91 \pm 22.401$ & $\mathrm{~ns}$ & -0.5211 \\
PLC & $296.51 \pm 36.545$ & & $858.163 \pm 80.41$ & & $12.3698^{* * *}$ \\
PLM & $619.133 \pm 539.988$ & & $671.855 \pm 264.819$ & & 0.1557 \\
\hline IPL & 225 & $296.66 \pm 117.185$ & $\mathrm{a}$ & $625.52 \pm 571.158$ & $\mathrm{~ns}$ & 0.8031 \\
PLC & $510.417 \pm 10.6389$ & $\mathrm{~b}$ & $498.21 \pm 299.545$ & & -0.0576 \\
PLM & $470.523 \pm 55.566$ & $\mathrm{a}, \mathrm{b}$ & $688.40 \pm 206.984$ & & 1.4541 \\
\hline
\end{tabular}

Níveis de significância: *: $\alpha<0.05 ; * * \alpha<0.01 ; * * *: \alpha<0.001$.

Avaliou-se o elemento $\mathrm{Mg}$ nas diferentes fases gestacionais, verificou-se que as amostras não apresentaram diferenças significativas entre as regiões amostradas com 90 $\left(F_{2,3}=2.29, \alpha=0.182\right), 135\left(F_{2,3}=3.116, \alpha=0.108\right)$ e $225 \operatorname{dias}\left(F_{2,3}=0.1228, \alpha=0.888\right)$.

O valor do GCL mostrou maiores valores do que os animais controle na região PLM aos 90 dias $(\mathrm{t}=9.1675, \alpha<0.01)$. O GCL também apresentou valores de concentração mais elevados para esse elemento do que o GCO na região PLC aos 135 dias $(\mathrm{t}=12.3698$, 
$\alpha<0.001)$. Nas outras regiões e períodos gestacionais, o GCL e GCO não apresentaram valores significativamente distintos (Tabela 4).

No GCO não houve variação ao longo do período gestacional nas regiões IPL $\left(\mathrm{F}_{2,5}=2.4081\right)(\alpha>0.05)$ (Figura 19), PLC $\left(\mathrm{F}_{2,5}=1.7055\right)(\alpha>0.05)$ e PLM $\left(\mathrm{F}_{2,5}=0.1677\right)$ $(\alpha>0.05)$ (Figura 20).

No GCL também não foram encontradas variações significativas entre os períodos gestacionais nas regiões IPL $\left(\mathrm{F}_{2,5}=0.1092, \alpha>0.05\right)$, PLC $\left(\mathrm{F}_{2,5}=0.3016, \alpha>0.05\right)$ e PLM $\left(\mathrm{F}_{2,5}=0.0986, \alpha>0.05\right)$.

A concentração total dos Mg diminuiu tanto para o GCO quanto para os GCL com o avançar do período gestacional (Figura 20). O GCL foi quem apresentou maior concentração de $\mathrm{Mg}$ em todos os períodos gestacionais.

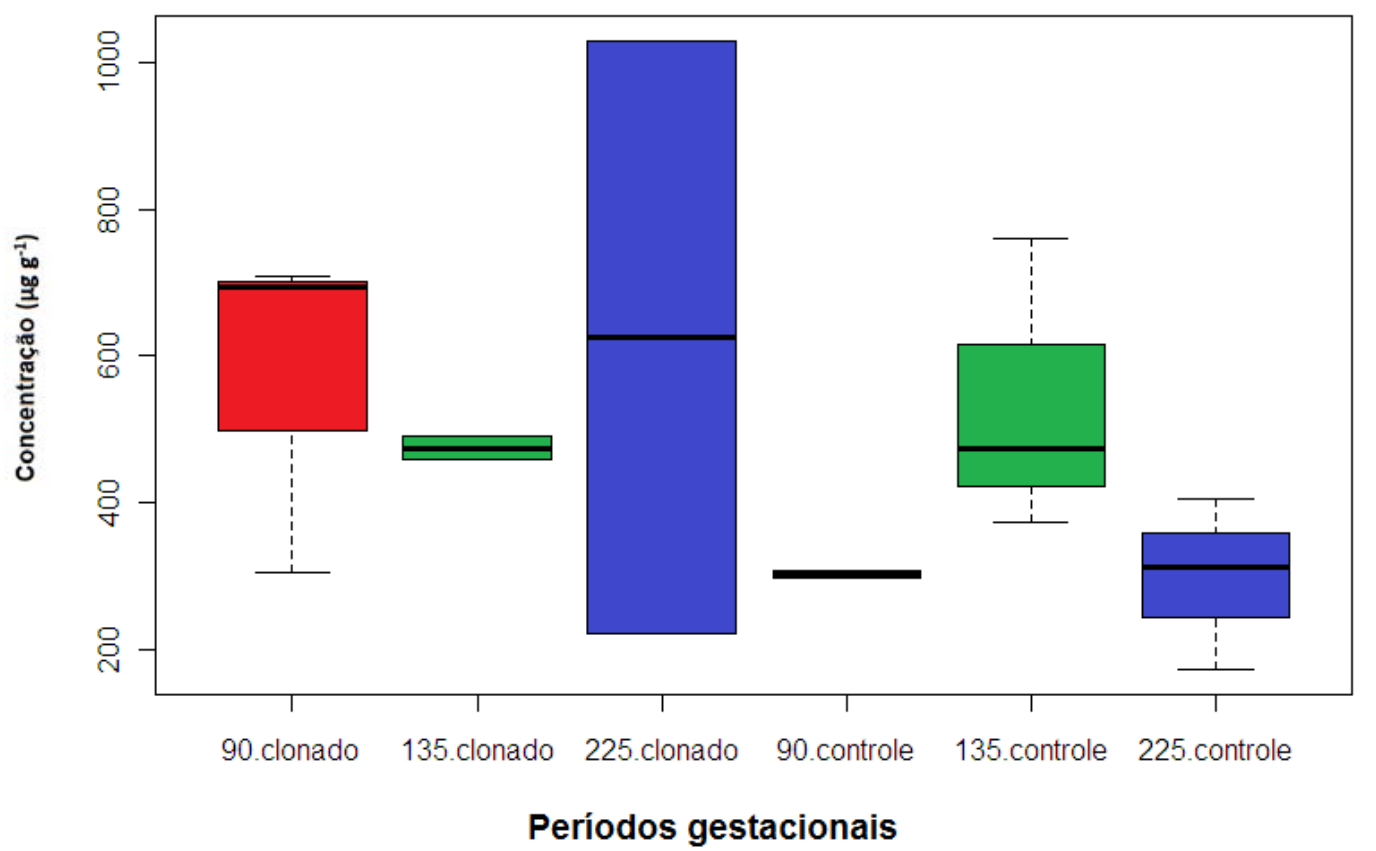

Figura 20 - Diagrama em caixa (boxplot) da concentração de magnésio ( $\left.\mu \mathrm{g} \mathrm{g}^{-1}\right)$ para a região IPL para todos os grupos e períodos gestacionais 


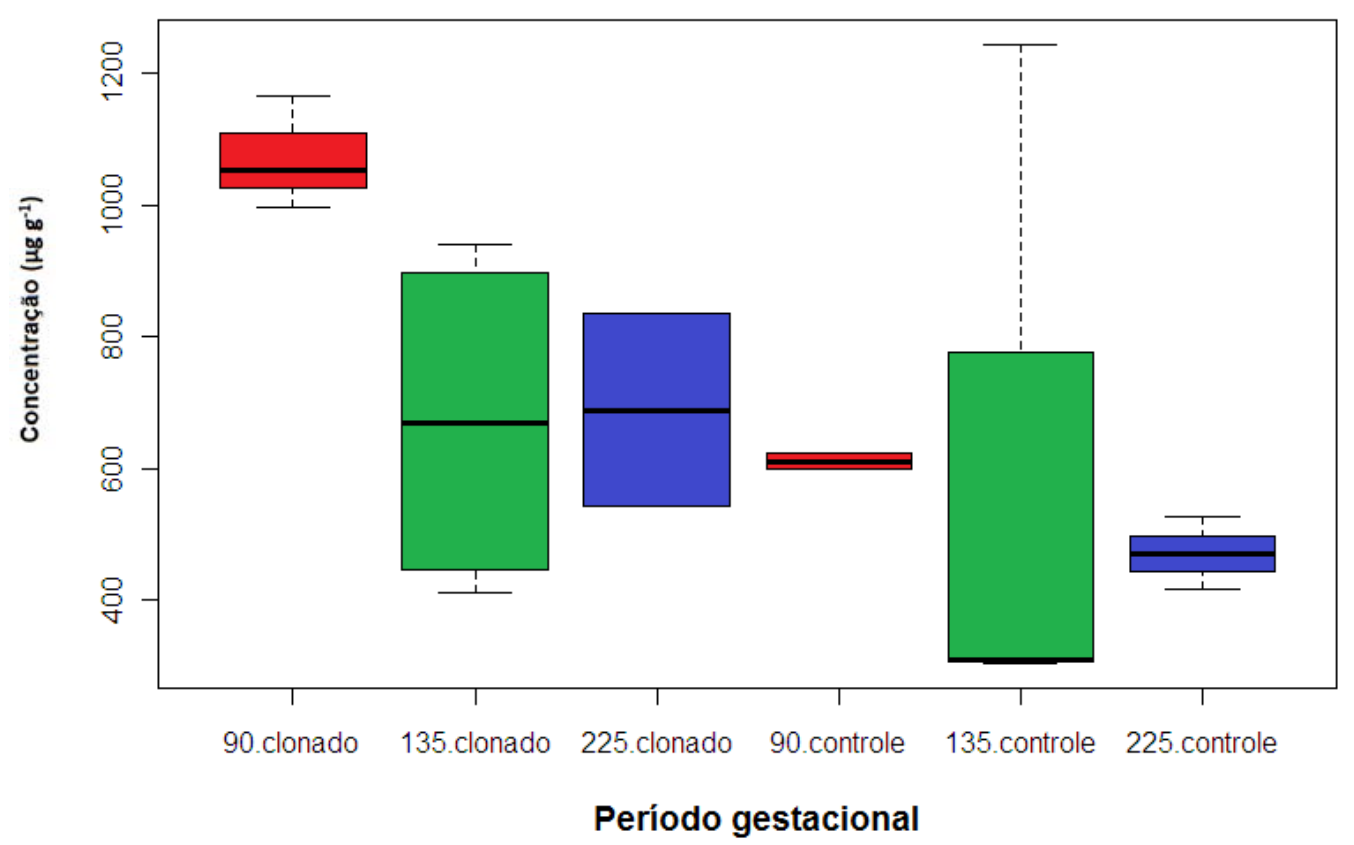

Figura 21 - Diagrama em caixa (boxplot) da concentração de magnésio $\left(\mu \mathrm{g} \mathrm{g}^{-1}\right)$ para a região PLM para todos os grupos e períodos gestacionais

O Magnésio é um elemento importante cujas concentrações apresentaram valores elevados durante o crescimento do tecido fetal e materno. Segundo Keen et al. 1998 muitos defeitos no desenvolvimento embrionário ou fetal podem ser causados causado por aporte inadequado de $\mathrm{Mg}$. $\mathrm{O}$ excesso de magnésio promove a deficiência de potássio e do cálcio. $\mathrm{O} \mathrm{Mg}$ desempenha um papel na transmissão e atividade meuromuscular, trabalhando em conjunto com o $\mathrm{Ca}$, na contração muscular normal, istó e, o Ca atua como um estimulador e o $\mathrm{Mg}$ como um relaxante. $\mathrm{O} \mathrm{Mg}$ também atua como um bloqueador do canal do cálcio fisiológico.

\subsubsection{Fósforo $(\mathrm{P})$}

Para o elemento fósforo verificou-se os valores de concentração para o período gestacional correspondente a 90 dias $(0.95 \% \pm 0.014)$ para a região PLM (Tabela 5).

A concentração de P mensurada apresentou-se significativamente distinta $(\alpha>0.05)$ para todas as regiões placentárias, exceto apenas para os períodos de 90 e 225 dias. 
Os animais GCL apresentaram uma concentração mais elevada que GCO, nas diferentes fases gestacionais avaliadas. Entre os animais GCL não encontramos variação significativa entre os períodos gestacionais na região IPL $\left(F_{2,5}=0.4727, \alpha>0.05\right)$, PLC $\left(\mathrm{F}_{2,5}=0.6122, \alpha>0.05\right)$ e PLM $\left(\mathrm{F}_{2,5}=0.1288, \alpha>0.05\right)$.

Aos 135 dias, as amostra do GCO para o GCL houveram diferenças significativas entre as regiões PLM $(0.727 \% \pm 0.24)$ e IPL $(0.337 \% \pm 0.042)$,

Aos 225 dias, as amostras do GCL GCO apresentaram concentrações de valores significativamente distintos entre PLM (Figura 24) e IPL (Figura 22).

Tabela 5 - Valores de fósforo (P) (\%) para GCO e para as regiões PLC, PLM e IPL Formação dos grupos segundo o teste de Tukey HSD (ANOVA, $\alpha<0.05$ ); ns: não significativo $(\alpha>0.05)$. Valor do teste t para GCO e GCL, localizados na mesma região do placentônio e mesmo período gestacional (90, 135 ou 225 dias), Instituto de Pesquisas Energéticas e Nucleares (IPEN), São Paulo, 2009-2010

\begin{tabular}{|c|c|c|c|c|c|c|}
\hline Região & dias & GCO & grupos & GCL & grupos & $\mathbf{t}$ \\
\hline IPL & 90 & $0.425 \% \pm 0.007$ & $\mathrm{a}$ & $0.6 \% \pm 0.216$ & ns & 1.8869 \\
\hline PLC & & $0.66 \% \pm 0.042$ & $a, b$ & $1.063 \% \pm 0.332$ & & 2.0788 \\
\hline PLM & & $0.95 \% \pm 0.014$ & $\mathrm{~b}$ & $1.00 \% \pm 0.07$ & & 1.201 \\
\hline IPL & 135 & $0.337 \% \pm 0.042$ & $\mathrm{a}$ & $0.38 \% \pm 0.0848$ & $\mathrm{a}$ & 0.6704 \\
\hline PLC & & $0.687 \% \pm 0.025$ & $a, b$ & $0.865 \% \pm 0.096$ & $\mathrm{a}$ & $3.5647 *$ \\
\hline PLM & & $0.727 \% \pm 0.24$ & $\mathrm{~b}$ & $0.9225 \% \pm 0.0434$ & $\mathrm{~b}$ & 1.3853 \\
\hline IPL & 225 & $0.287 \% \pm 0.038$ & $\mathrm{a}$ & $0.69 \% \pm 0.579$ & ns & 0.9823 \\
\hline PLC & & $0.533 \% \pm 0.0643$ & $a, b$ & $0.855 \% \pm 0.389$ & & 1.1592 \\
\hline PLM & & $0.773 \% \pm 0.3003$ & $\mathrm{~b}$ & $0.787 \% \pm 0.163$ & & 0.0607 \\
\hline
\end{tabular}

Níveis de significância: *: $\alpha<0.05 ; * * \alpha<0.01 ; * * *: \alpha<0.001$.

Entre o GCL, aos 135 dias a região IPL apresentou concentração significativamente menor $(0.38 \% \pm 0.0848)$ do que as regiões PLM $(0.9225 \% \pm 0.0434)$ e PLC $(0.865 \% \pm 0.096)$, sendo estas duas últimas indistintas entre si ao nível de 5\% de significância.

Na região PLC aos 90 dias ( $\mathrm{t}=3.5647, \alpha<0.05$, Tabela 5), amostra do GCL o GCL apresentaram valores médios superiores $(0.865 \% \pm 0.096)$ em comparação com o GCO $(0,687 \% \pm 0,025)$. Nas outras regiões e períodos gestacionais, as amostras do GCL e GCO não apresentaram concentrações significativamente distintas.

Para as amostras do GCO não houve variação significativa para a região PLM $\left(F_{2,5}=0.5312, \alpha>0.05\right)$, mas houve variação nas concentrações de fósforo ao longo do período gestacional na região IPL, sendo que aos 90 dias foram encontrados os maiores valores, 
sendo significativamente distinto ao período de 225 dias, mas ambos não diferindo dos valores encontrados aos 135 dias. Na região PLC, o pico encontrado foi aos 135 dias, sendo significativamente distinto ao valor médio encontrado aos 225 dias. Aos 90 dias, os valores encontrados não diferiram com os períodos de 135 e 225 dias.

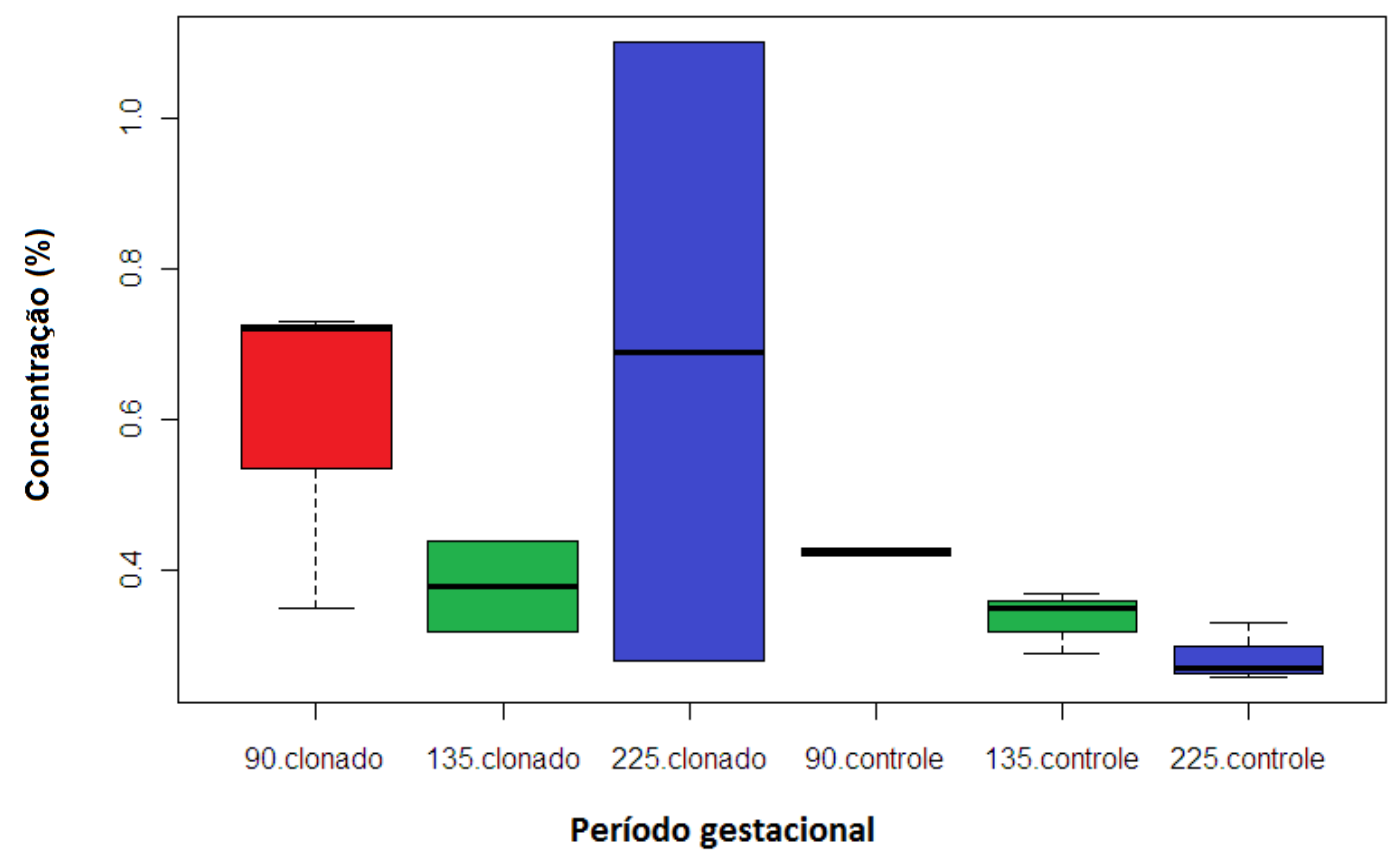

Figura 22 - Diagrama em caixa (boxplot) da concentração de fósforo (\%) para a região IPL para todos os grupos e períodos gestacionais 


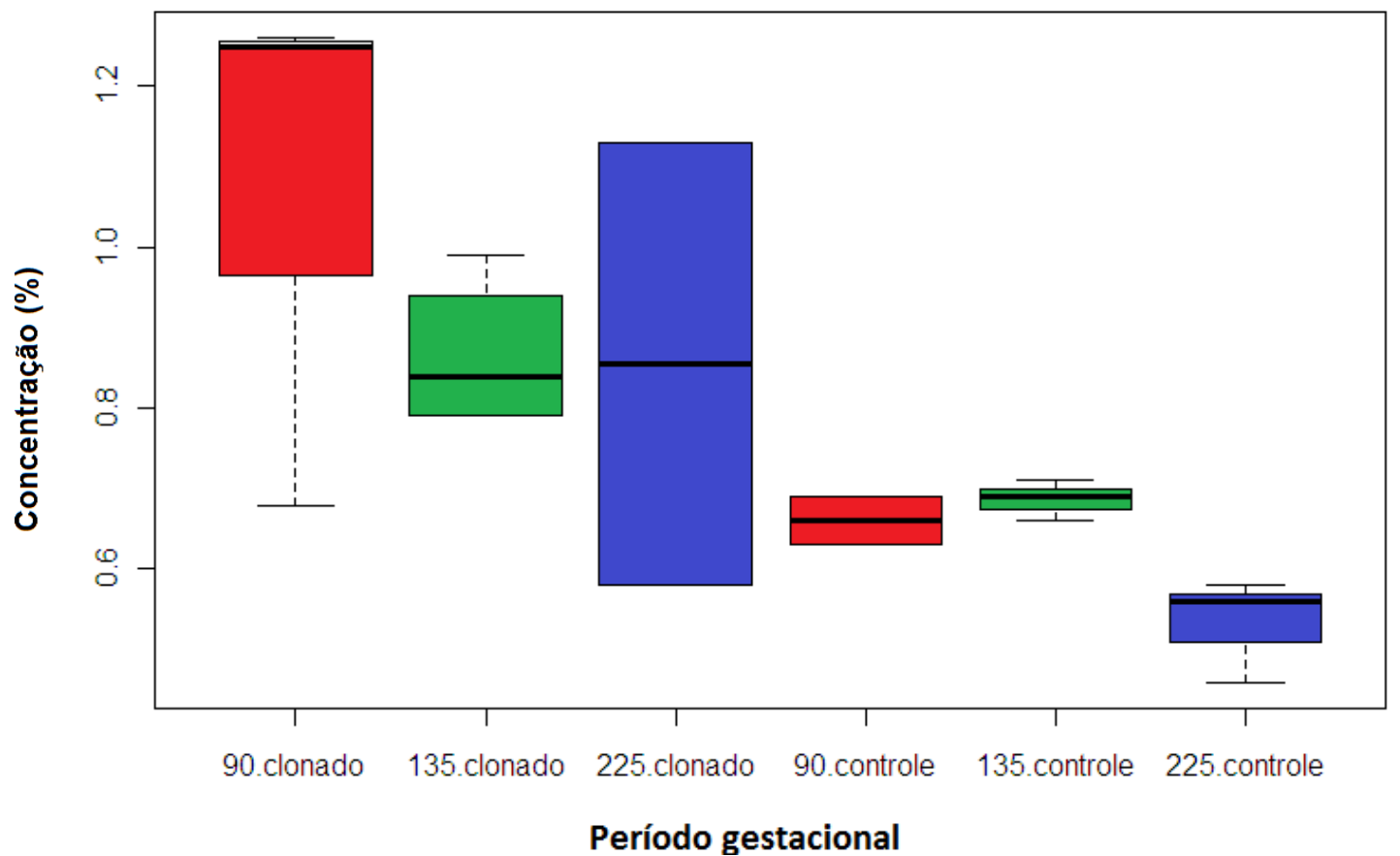

Figura 23 - Diagrama em caixa (boxplot) da concentração de fósforo (\%) para a região PLC para todos os grupos e períodos gestacionais

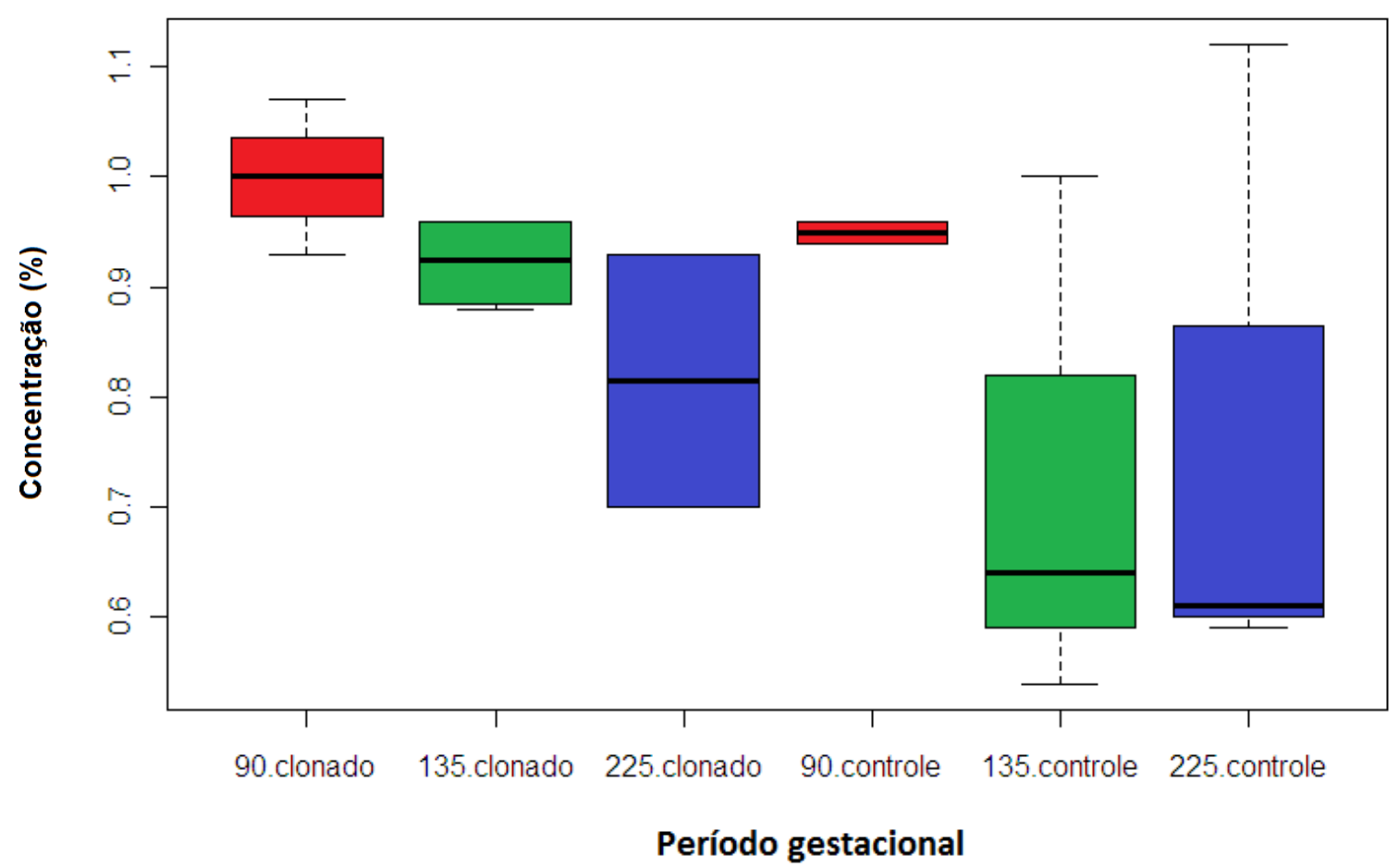

Figura 24- Diagrama em caixa (boxplot) da concentração de fósforo (\%) para a região PLM para todos os grupos e períodos gestacionais 
O fósforo é essencial nos processos de transferência de energia, na deficiência desse elemento a hipófise não funciona. Esse elemento está freqüentemente associado com anormalidades reprodutivas no bovino. O fósforo é um componente de ácidos nucléicos, fosfolipídios e algumas proteínas, necessárias para a transferência e utilização de energia e no metabolismo de fosfolipídios é componente de inúmeras coenzimas. Lotthammer, 1988 comprovou em seus estudos que as vacas que possuem excesso de $\mathrm{P}$ possuem menor taxa de fertilidade. Um excesso na administração de P pode acarretar, negativamente, na absorção de $\mathrm{Ca}, \mathrm{Zn}$ e Fe.

\subsubsection{Cloro $(\mathrm{Cl})$}

Os valores médios de concentração para o $\mathrm{Cl}$ estão apresentados na tabela 6 .

O GCO amostrado aos 90 dias, a região PLM (Figura 27) apresentou valores percentuais significativamente maiores do que as regiões PLC (Figura 26) e IPL (Figura 25), não sendo encontrada diferença significativa entre estas duas últimas regiões.

As concentrações para GCL foram significativamente maiores em comparação ao GCO na região PLM aos 90 dias de gestação ( $\mathrm{t}=6.0531, \alpha<0.05$, Tabela 8).

Tabela 6 - Valores de cloro $(\mathrm{Cl})(\%)$ para GCO e GCL para as regiões PLC, PLM e IPL Formação dos grupos segundo o teste de Tukey HSD (ANOVA, $\alpha<0.05$ ); ns: não significativo $(\alpha>0.05)$. Valor do teste $\mathrm{t}$ para GCO e GCL, localizados na mesma região do placentônio e mesmo período gestacional (90, 135 ou 225 dias) Instituto de Pesquisas Energéticas e Nucleares (IPEN), São Paulo, 2009-2010

\begin{tabular}{lllllll}
\hline Região & dias & Controle & grupos & Clonados & \multicolumn{2}{c}{ grupos } \\
\hline IPL & 90 & $0.525 \% \pm 0.007$ & $\mathrm{a}$ & $1.127 \% \pm 0.491$ & $\mathrm{~ns}$ & 2.1214 \\
PLC & $0.545 \% \pm 0.0212)$ & $\mathrm{a}$ & $0.727 \% \pm 0.196$ & & 1.5952 \\
PLM & $0.735 \% \pm 0.0636$ & $\mathrm{~b}$ & $1.103 \% \pm 0.071$ & & $6.0531^{*}$ \\
\hline IPL & 135 & $0.72 \% \pm 0.217$ & $\mathrm{~ns}$ & $0.615 \% \pm 0.233$ & $\mathrm{~ns}$ & -0.5072 \\
PLC & $0.59 \% \pm 0.017$ & & $0.73 \% \pm 0.161$ & & 1.7298 \\
PLM & $0.673 \% \pm 0.191$ & & $0.783 \% \pm 0.205$ & & 0.7235 \\
\hline IPL & 225 & $0.667 \% \pm 0.149$ & $\mathrm{~ns}$ & $0.62 \% \pm 0.169$ & $\mathrm{~ns}$ & -0.3155 \\
PLC & $0.427 \% \pm 0.04$ & & $0.535 \% \pm 0.148$ & & 1.0072 \\
PLM & $0.57 \% \pm 0.193$ & & $0.665 \% \pm 0.064$ & & 0.7901 \\
\hline
\end{tabular}

Níveis de significância: *: $\alpha<0.05 ; * * \alpha<0.01 ; * * *: \alpha<0.001$. 
Não foram encontradas variações ao longo do período gestacional para as regiões IPL $\left(\mathrm{F}_{2,5}=0.8429, \alpha>0.05\right)$ e PLM $\left(\mathrm{F}_{2,5}=0.5806, \alpha>0.05\right)$ o GCO. Na região PLC, aos 225 dias os valores foram significativamente menores que nos períodos de 90 e 135 dias, sendo estes dois últimos períodos, significativamente semelhantes (Figura 26).

Não foram encontradas variações significativas entre os períodos gestacionais para as regiões IPL $\left(\mathrm{F}_{2,5}=1.5713, \alpha>0.05\right)$ e PLC $\left(\mathrm{F}_{2,5}=0.9943, \alpha>0.05\right)$ (Figura 25). Na região PLM foram encontradas diferenças significativas na concentração do período de 90 dias com os períodos de 135 e 225 dias, não sendo encontrada diferença significativa entre estes dois últimos períodos (Figura 27).

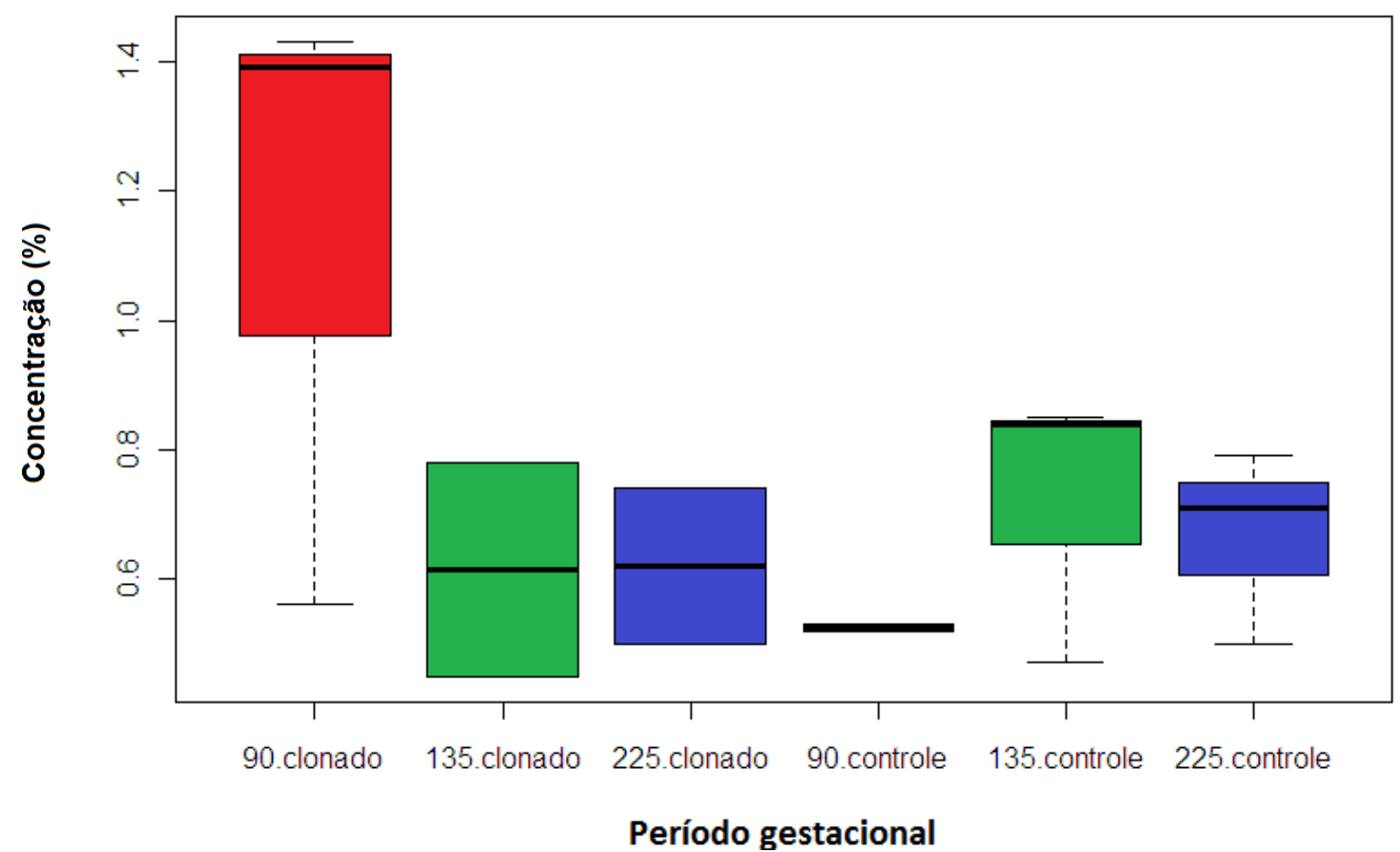

Figura 24 - Diagrama em caixa (boxplot) da concentração de cloro (\%) para a região IPL para todos os grupos e períodos gestacionais 


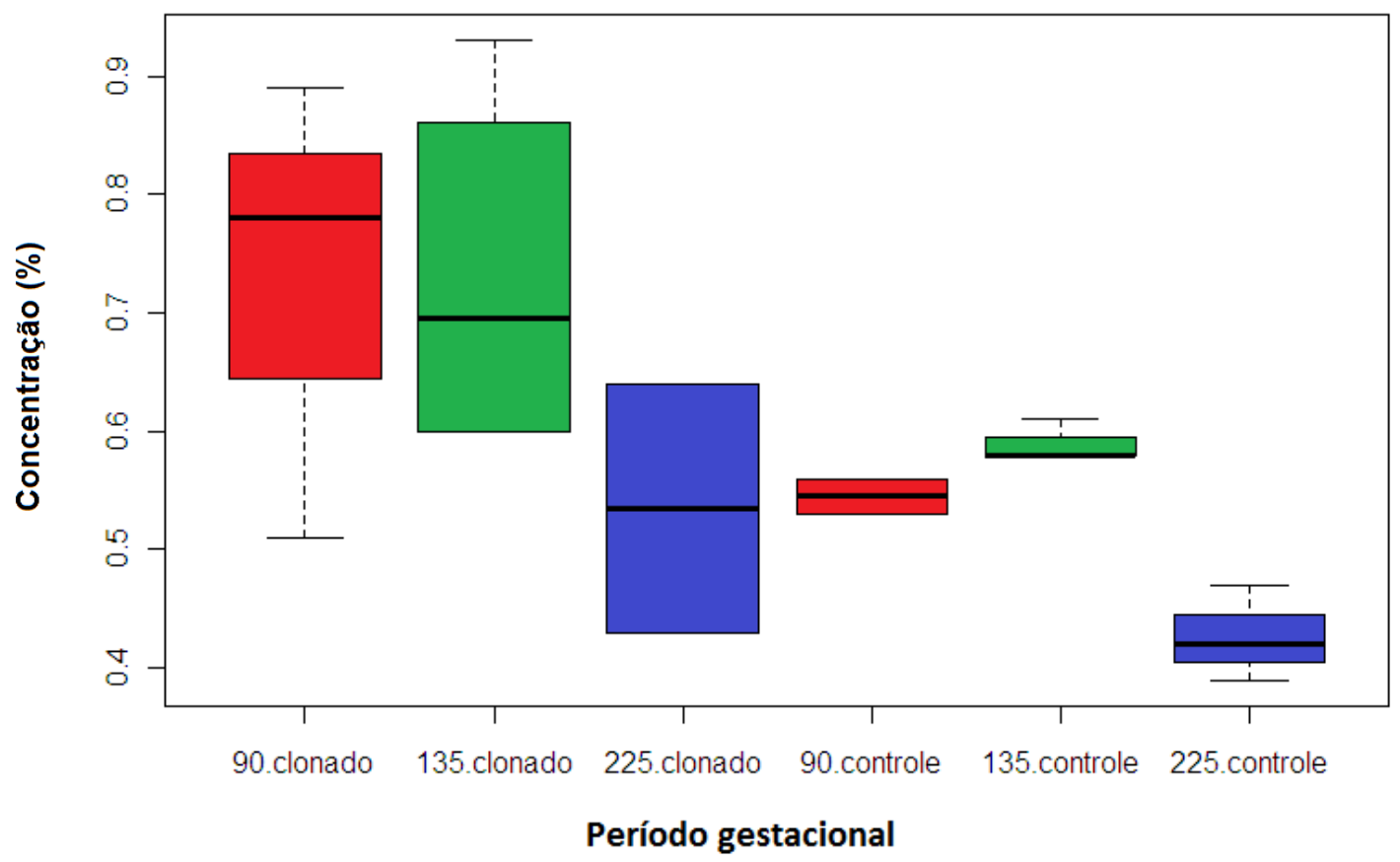

Figura 25 - Diagrama em caixa (boxplot) da concentração valores de cloro (\%) para a região PLC para todos os grupos e períodos gestacionais

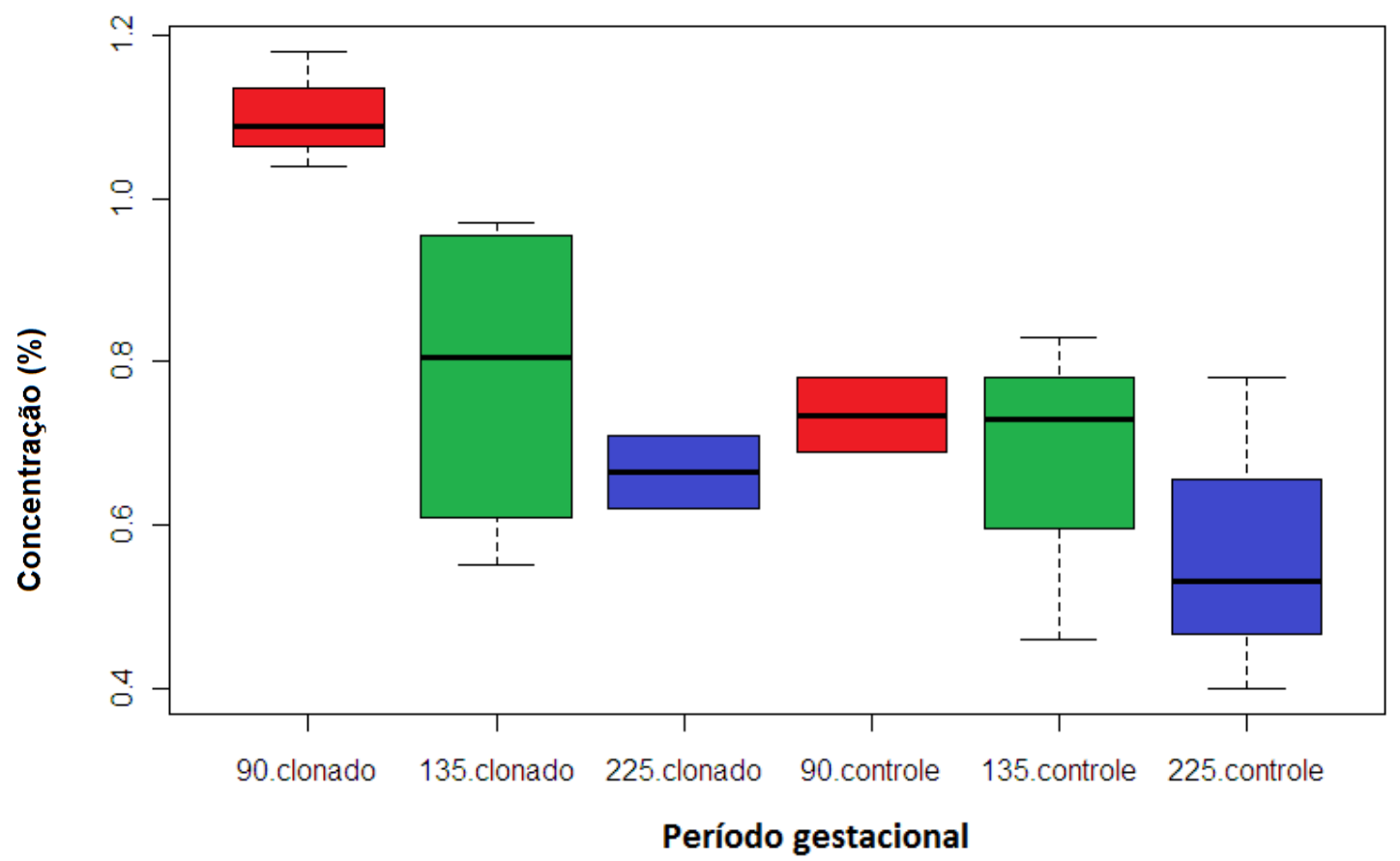

Figura 26 - Diagrama em caixa (boxplot) da concentração de cloro (\%) para a região PLM para todos os grupos e períodos gestacionais 
Aplicando o teste ANOVA, verificou-se que as amostras correspondentes GCL apresentaram diferença significativa. Diminuindo a concentração com o avanço do período gestacional.

Juntamente com o P e Na, o $\mathrm{Cl}$ está envolvido na manutenção da pressão osmótica e dos sistemas tampão nos fluídos intra e extracelular, no transporte de nutrientes e na transmissão de impulsos nervosos (UNDERWOOD; SUTTER, 1999). Atua na ativação da amilase e é um componente essencial do ácido clorídrico $(\mathrm{HCl})$ do suco gástrico. Tanto o $\mathrm{Na}$ como $\mathrm{Cl}$ apresentaram em concentrações maiores em tecidos moles e nos fluidos corporais, o Cl encontra-se dentro e fora da célula (MCDOWELL, 1990).

\subsubsection{Potássio $(\mathrm{K})$}

Avaliou-se o K nas diferentes regiões da placenta, o nível de potássio variou entre as regiões coletadas aos 90 dias para o GCO. A região IPL apresentou concentrações significativamente menores do que as regiões PLM e PLC, tendo estas duas últimas regiões valores significativamente distintos (Tabela 7).

Aos 135 dias, o GCO apresentou variações nos níveis de potássio entre as regiões placentárias PLC e IPL, mas estas duas últimas não apresentaram diferenças significativas quando comparada com a região PLM (Tabela 7).

Tabela 7 - Valores de Potássio (K) (\%) para GCO e GCL para as regiões PLC, PLM e IPL Formação dos grupos segundo o teste de Tukey HSD (ANOVA, $\alpha<0.05$ ); ns: não significativo $(\alpha>0.05)$. Valor do teste t para GCO e GCL, localizados na mesma região do placentônio e mesmo período gestacional (90, 135 ou 225 dias), Instituto de Pesquisas Energéticas e Nucleares (IPEN) , São Paulo, 2009-2010

\begin{tabular}{|c|c|c|c|c|c|c|}
\hline região & dias & Controle & grupos & Clonados & grupos & $\mathbf{t}$ \\
\hline IPL & 90 & $0.255 \pm 0.0071$ & $\mathrm{a}$ & $0.896 \pm 0.0814$ & ns & $13.5695^{* *}$ \\
\hline PLC & & $0.84 \pm 0.1697$ & $\mathrm{~b}$ & $1.503 \pm 0.488$ & & 2.1642 \\
\hline PLM & & $1.525 \pm 0.0636$ & $\mathrm{c}$ & $1.45 \pm 0.053$ & & -1.3789 \\
\hline IPL & 135 & $0.63 \pm 0.1$ & $\mathrm{a}$ & $0.56 \pm 0.226$ & $\mathrm{a}$ & -0.4115 \\
\hline PLC & & $1.567 \pm 0.4309$ & $\mathrm{~b}$ & $1.3 \pm 0.0693$ & $\mathrm{~b}$ & -1.0615 \\
\hline PLM & & $1.1367 \pm 0.298$ & $\mathrm{a}, \mathrm{b}$ & $1.357 \pm 0.154$ & $\mathrm{~b}$ & 1.1704 \\
\hline IPL & 225 & $0.56 \pm 0.20$ & ns & $1.165 \pm 0.643$ & ns & 1.2885 \\
\hline PLC & & $0.793 \pm 0.03$ & & $1.325 \pm 0.544$ & & 1.3795 \\
\hline PLM & & $1.140 \pm 0.442$ & & $1.195 \pm 0.148$ & & 0.1994 \\
\hline
\end{tabular}

Níveis de significância: *: $\alpha<0.05 ; * * \alpha<0.01 ; * * *: \alpha<0.001$. 
Para o GCL, coletados aos 135 dias, houveram diferenças significativas entre as regiões PLC e PLM em comparação região IPL, sendo as duas primeiras regiões indistintas ao nível de significância de 5\% (Tabela 7).

As regiões coletadas aos $90\left(F_{2,6}=4.09, \alpha=0.075\right)$ e $225\left(F_{2,3}=0.0592, \alpha=0.944\right) \mathrm{em}$ GCL, e aos 225 dias $\left(F_{2,6}=3.243, \alpha=0.119\right)$ para o GCO não mostraram diferenças significativas para a concentração de potássio.

$\mathrm{Na}$ região IPL, aos 90 dias de gestação, GCL apresentou valores médios significativamente maiores $(\mathrm{t}=13.595, \alpha<0.001)$ que GCO. Nas outras regiões e períodos gestacionais, GCL e GCO não apresentaram valores significativamente distintos (Tabela 7)

A região PLC, o GCO, apresentou valores distintos entre os períodos de 135 e 225 dias, conforme a figura 29. As regiões PLM $\left(\mathrm{F}_{2,5}=0.9797, \alpha>0.05\right)$ e IPL $\left(\mathrm{F}_{2,5}=4.4896\right.$, $\alpha>0.05$ ) para o GCO, não apresentaram variações significativas entre os períodos gestacionais (Figura 28 e 30 ).

No GCL não foram encontradas diferenças significativas entre os períodos gestacionais para as regiões IPL $\left(\mathrm{F}_{2,4}=1.5382, \alpha>0.05\right)$, PLC $\left(\mathrm{F}_{2,6}=0.7564, \alpha>0.05\right)$ e PLM $\left(F_{2,6}=2.3722, \alpha>0.05\right)$, não havendo variação ao longo da gestação.

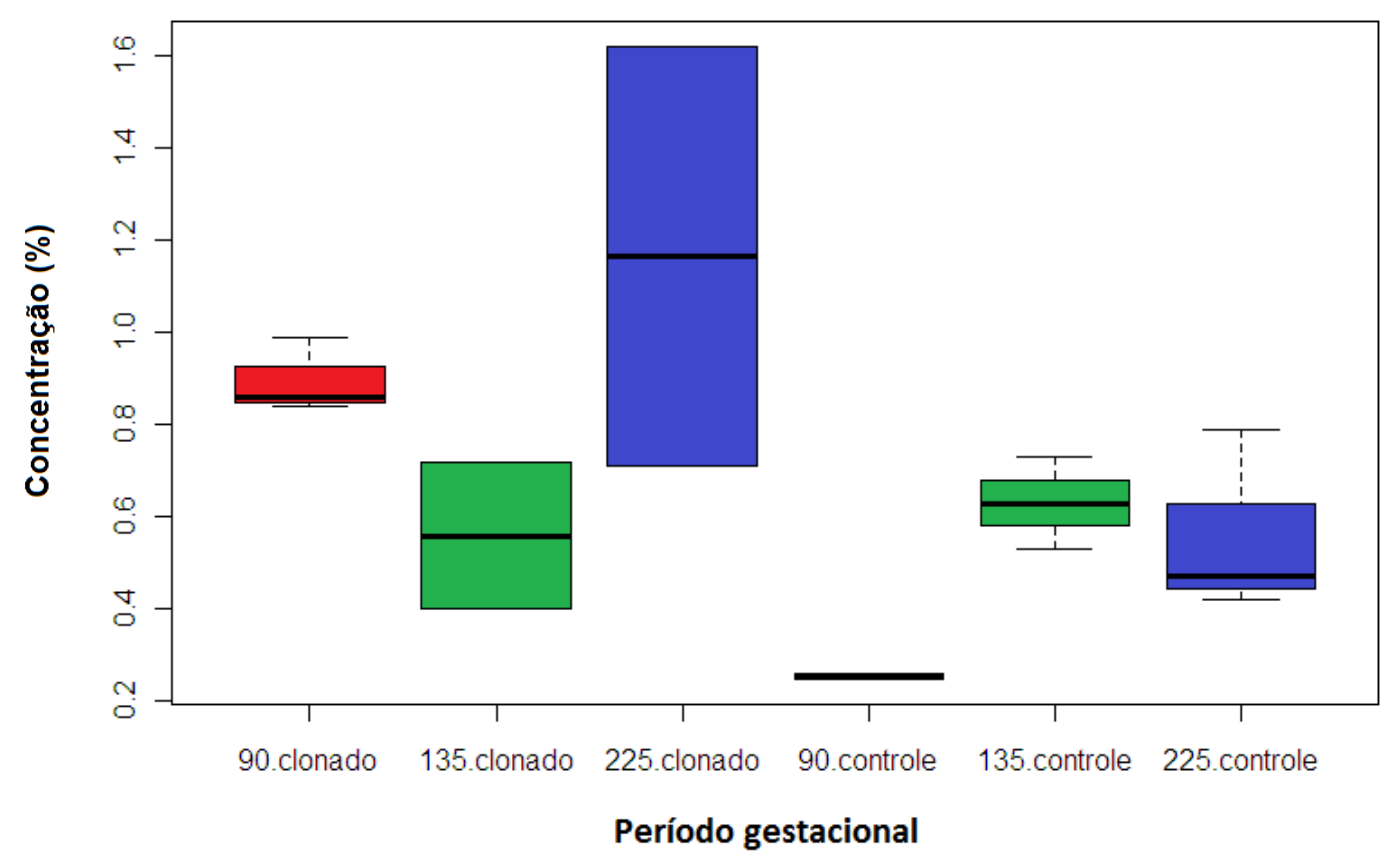

Figura 27 - Diagrama em caixa (boxplot) da concentração valores de potássio (\%) para a região IPL para todos os grupos e períodos gestacionais 


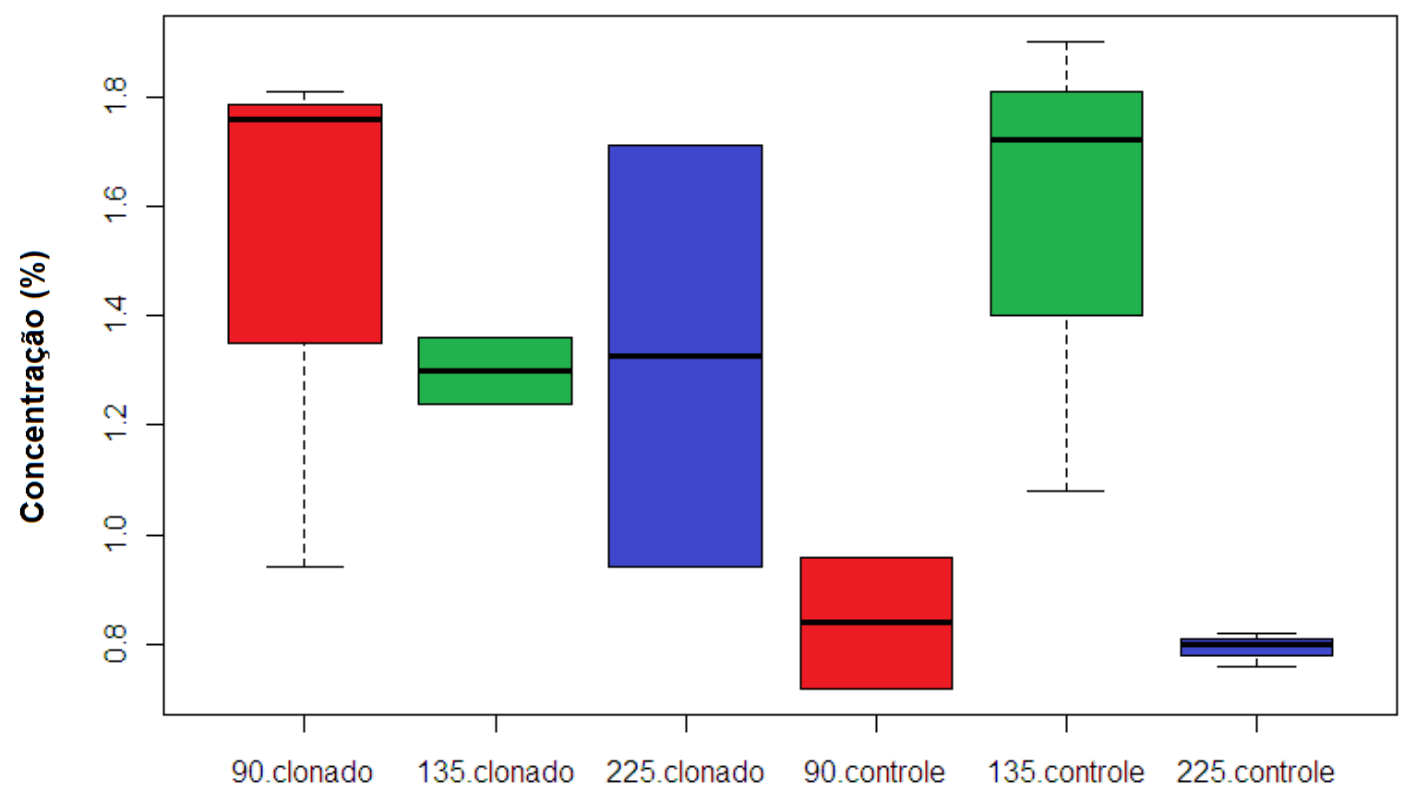

Período gestacional

Figura 28 - Diagrama em caixa (boxplot) da concentração de potássio (\%) para a região PLC para todos os grupos e períodos gestacionais

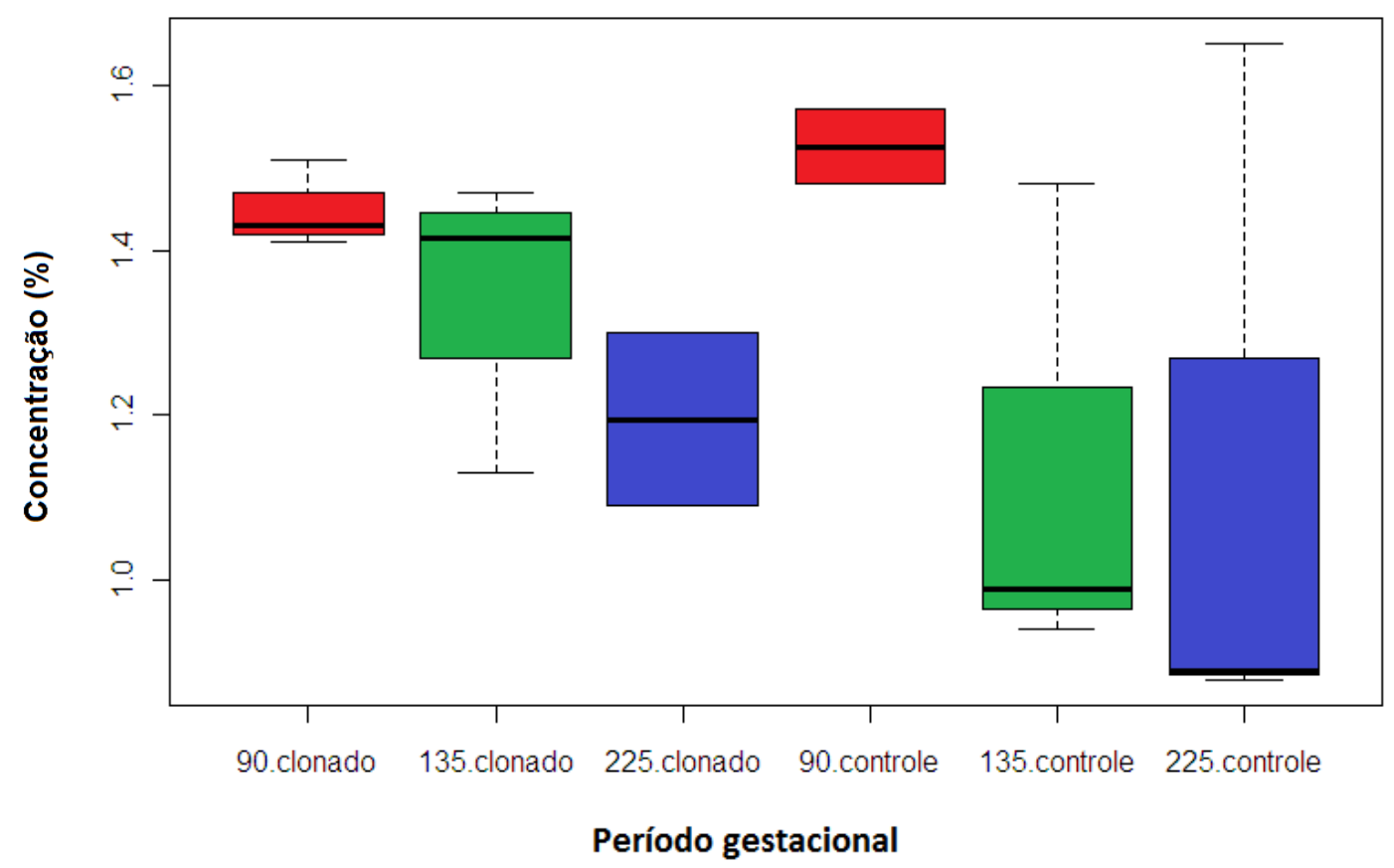

Figura 29 - Diagrama em caixa (boxplot) da concentração de potássio (\%) para a região PLM para todos os grupos e períodos gestacionais 
Segundo MCDOWELL (1999), as principais funções do potássio são equilíbrio osmótico, ácido-base, exercendo influência sobre a atividade muscular. No trabalho de Fuck, Moraes e Santos (2005) ocorreu uma redução na taxa de fertilidade com níveis elevados de potássio e baixos de $\mathrm{Na}$, ou com uma razão $\mathrm{K}-\mathrm{Na}$ ampla. Estes dois elementos são antagônicos, isto é, um excesso de potássio está associado a uma deficiência de $\mathrm{Na}$, ocasionando no aparecimento de cios irregulares, estros prolongados ou permanentes, cistos.

\subsubsection{Cálcio $(\mathrm{Ca})$}

Avaliou-se o elemento Ca nas regiões da placenta, nas amostras do GCO, as amostras coletadas aos 225 dias não mostraram diferenças significativas entre as regiões $\left(\mathrm{F}_{2,6}=3.1147\right.$, $\alpha=0.1181$ ). A região IPL foi a região com menores valores de $\mathrm{Ca}$, seguida pela região PLC. PLM correspondeu a região com os maiores valores de cálcio (Tabela 8).

Aos 135 dias, todas as regiões também apresentaram valores médios distintos entre si no GCO.

Tabela 8 - Valores de cálcio $(\mathrm{Ca})\left(\mu \mathrm{g} \mathrm{g}^{-1}\right)$ para GCO e GCL para as regiões PLC, PLM e IPL Formação dos grupos segundo o teste de Tukey HSD (ANOVA, $\alpha<0.05)$; ns: não significativo $(\alpha>0.05)$. Valor do teste t para GCO e GCL , localizados na mesma região do placentônio e mesmo período gestacional (90, 135 ou 225 dias), Instituto de Pesquisas Energéticas e Nucleares (IPEN), São Paulo, 2009-2010

\begin{tabular}{lllllll}
\hline região & dias & Controle & \multicolumn{2}{l}{ grupos } & Clonados & \multicolumn{2}{l}{ grupos } & t \\
\hline IPL & 90 & $138.77 \pm 5.501$ & $\mathrm{a}$ & $973.35 \pm 637.143$ & $\mathrm{~ns}$ & 2.2687 \\
$\mathrm{PLC}$ & & $252.02 \pm 20.237$ & $\mathrm{~b}$ & $583.697 \pm 204.632$ & & 2.787 \\
$\mathrm{PLM}$ & $397.92 \pm 24.763$ & $\mathrm{c}$ & $690.907 \pm 120.007$ & & $4.0998^{*}$ \\
\hline IPL & 135 & $180.383 \pm 26.672$ & $\mathrm{a}$ & $221.18 \pm 53.854$ & $\mathrm{a}$ & 0.9932 \\
PLC & $407.71 \pm 13.21$ & $\mathrm{c}$ & $428.763 \pm 18.835$ & $\mathrm{~b}$ & 1.7372 \\
PLM & $324.377 \pm 30.331$ & $\mathrm{~b}$ & $428.915 \pm 34.729$ & $\mathrm{~b}$ & $4.239^{*}$ \\
\hline IPL & 225 & $203.037 \pm 47.95$ & $\mathrm{~ns}$ & $294.325 \pm 112.31$ & $\mathrm{~ns}$ & 1.0855 \\
PLC & $235.053 \pm 20.314$ & & $290.97 \pm 67.925$ & & 1.131 \\
PLM & $346.113 \pm 116.535$ & & $368.995 \pm 6.937$ & & 0.3392 \\
\hline Níveis de significância: $*: \alpha<0.05 ; * * \alpha<0.01 ; * * *: \alpha<0.001$. & &
\end{tabular}


No GCL, as coletas realizadas aos $90\left(\mathrm{~F}_{2,6}=0.7889, \alpha=0.496\right)$ e 225 dias $\mathrm{F}_{2,3}=0.6758$, $\alpha=0.5724$ ) não apresentaram distinção entre as regiões amostradas.

Aos 135 dias, a região IPL (Figura 31) apresentou valores significativamente menores que as regiões PLC (Figura 32) e PLM (Figura 33), sendo estas duas últimas regiões indistintas entre si, ao nível de 5\% de significância (Tabela 8).

A região PLM mostrou diferenças significativas para o período de $90(\mathrm{t}=4.0998$, $\alpha<0.05$, tabela 6$)$ e 135 dias $(\mathrm{t}=4.239, \alpha<0.05)$. Os animais GCL mostraram valores maiores de concentração para o $\mathrm{Ca}$ do que o GCO tanto aos 90, quanto aos 135 dias de gestação. Nas outras regiões e períodos gestacionais, os grupos não apresentaram valores significativamente distintos (Tabela 8).

Para o GCO, a região PLC apresentou variação significativa na concentração de Ca para o período de 135 dias (Figura 32). Nas regiões IPL $\left(\mathrm{F}_{2,5}=2.0549, \alpha>0.05\right)$ e PLM $\left(F_{2,5}=0.5573, \alpha>0.05\right)$, os animais controle apresentaram variação nos valores ao longo do período gestacional (Figura 31).

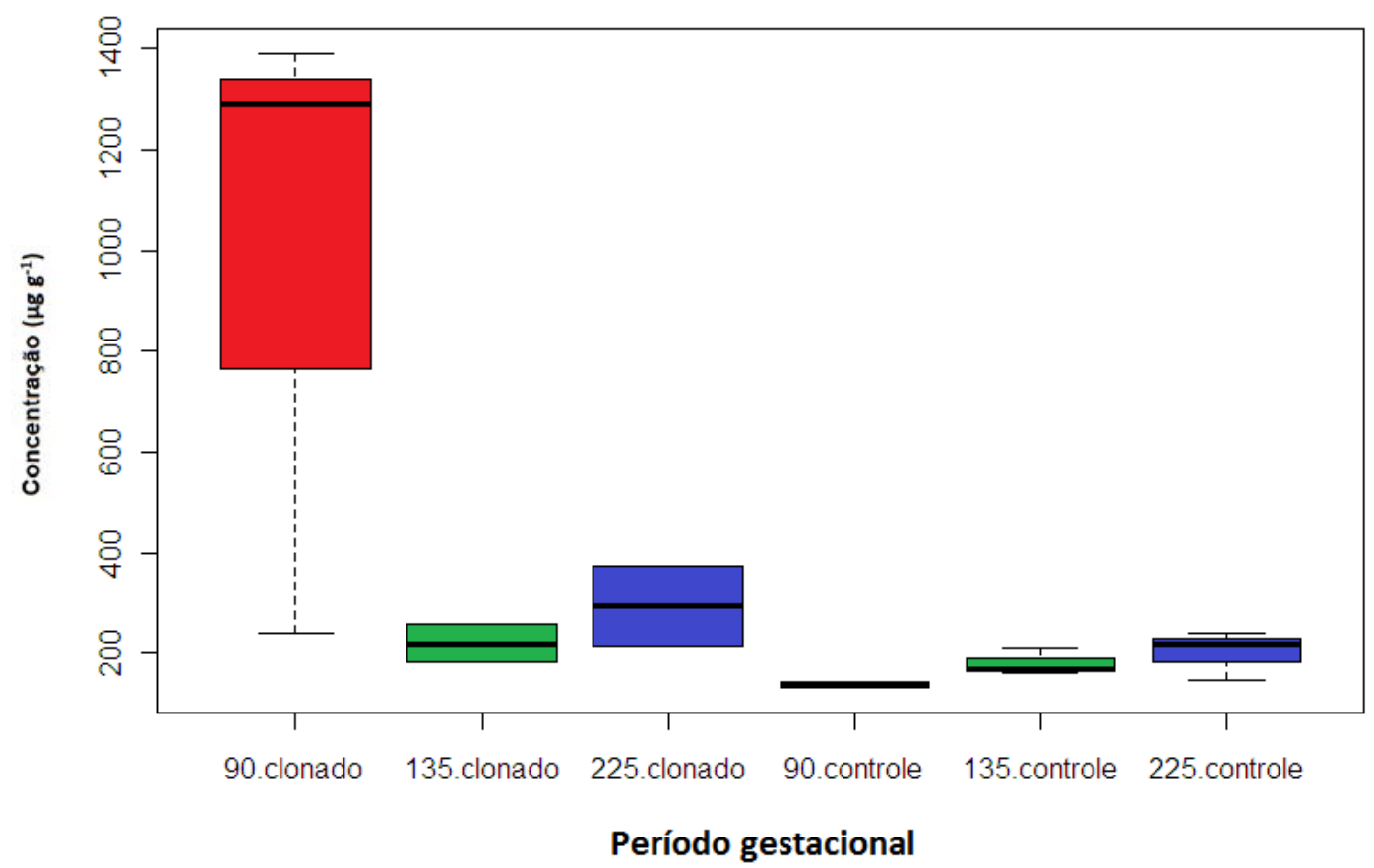

Figura 30 - Diagrama em caixa (boxplot) da concentração de cálcio $\left(\mu \mathrm{g} \mathrm{g}^{-1}\right)$ para a região IPL para todos os grupos e períodos gestacionais 


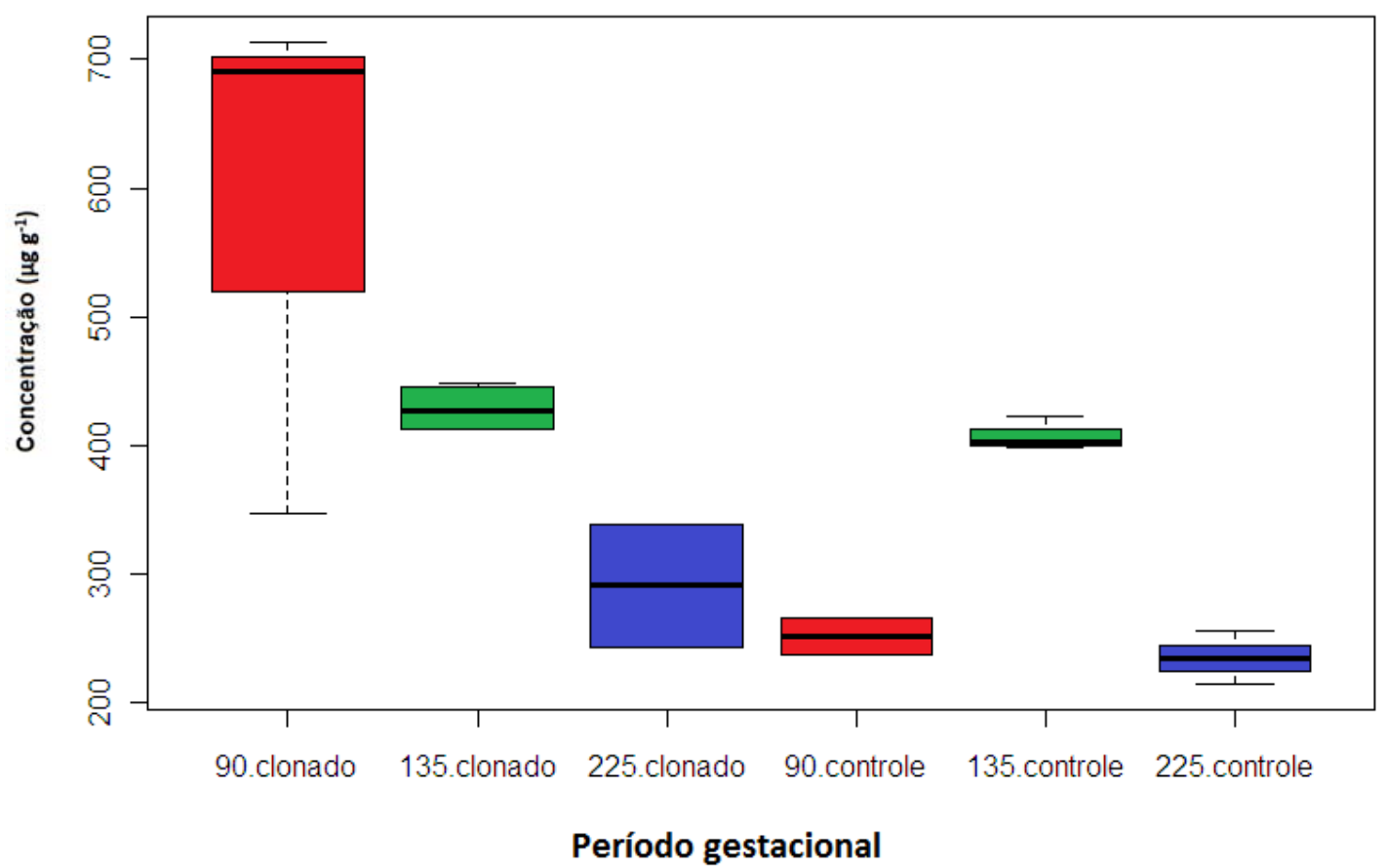

Figura 31 - Diagrama em caixa (boxplot) da concentração de cálcio $\left(\mu \mathrm{g} \mathrm{g}^{-1}\right)$ para a região PLC para todos os grupos e períodos gestacionais

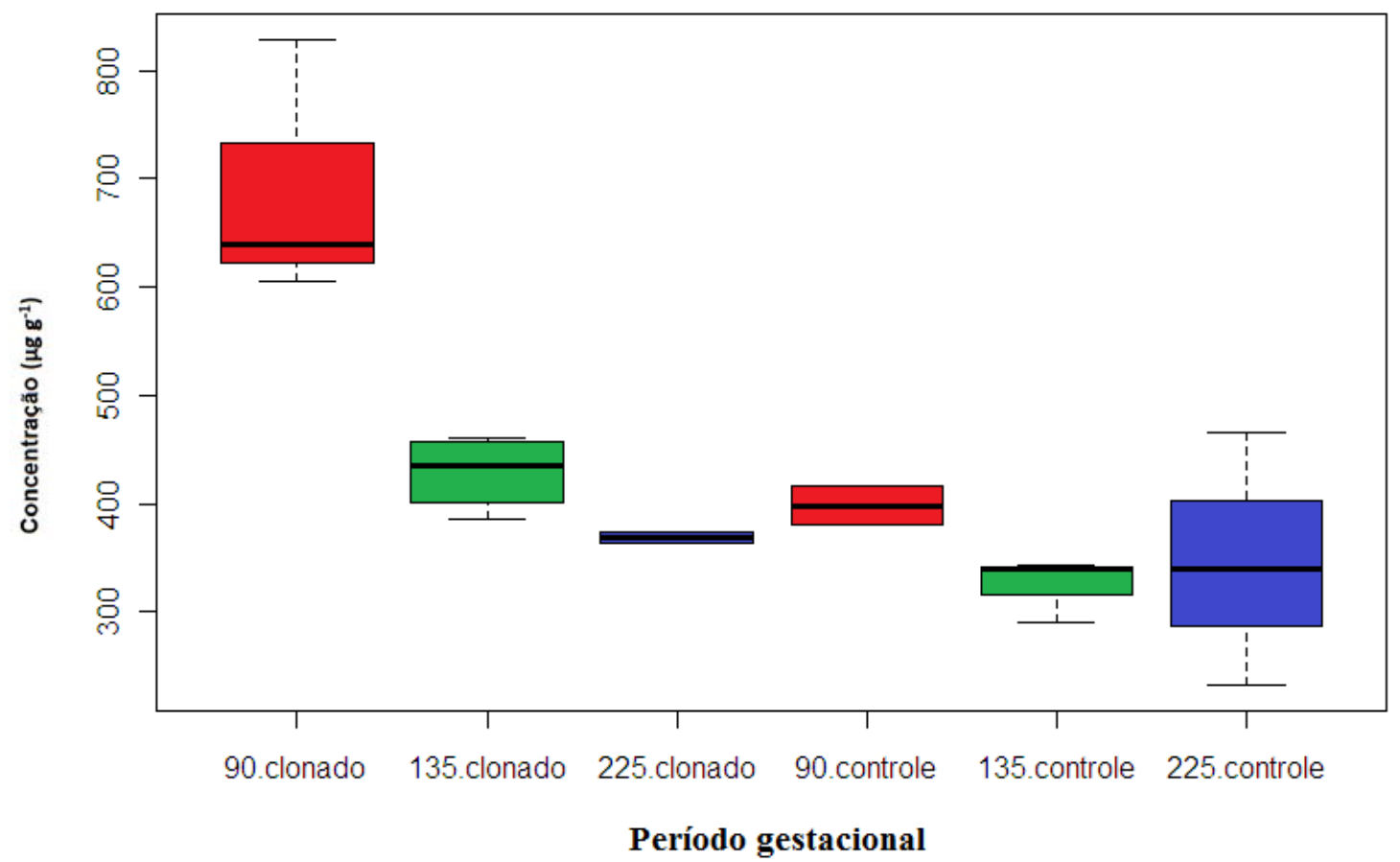

Figura 32 - Diagrama em caixa (boxplot) da concentração de cálcio $\left(\mu \mathrm{g} \mathrm{g}^{-1}\right)$ para a região PLM para todos os grupos e períodos gestacionais 
Nos animais GCL, não houve alteração nos valores médios ao longo do período gestacional para as regiões IPL $\left(\mathrm{F}_{2,4}=, \alpha>0.05\right)$ e PLC $\left(\mathrm{F}_{2,6}=, \alpha>0.05\right)$. Na região PLM, aos 90 dias foram encontrados valores significativamente distintos aos outros dois períodos de amostragem (Figura 33), não sendo encontrada diferença significativa entre os períodos de 135 e 225 dias.

O cálcio apresentou concentração média mais elevada no GCL, diminuindo a concentração com avançar do período gestacional (Figura 31, 32 e 33).

Baixas taxas de cálcio podem ocasionar um atraso na involução uterina e aumento da incidência de distócias, retenção de placenta e prolapso de útero. Sua concentração é importante para a manutenção e o controle de vários processos bioquímicos. Na célula atua como segundo mensageiro, regulando as reações celulares (MATALOUN; LEONE, 2007).

$\mathrm{O}$ excesso de cálcio pode prejudicar a função reprodutiva devido a uma deficiência secundária de $\mathrm{P}, \mathrm{Mg}, \mathrm{Zn}$ e $\mathrm{Cu}$ e outros elementos traço . O mecanismo de dependentes de $\mathrm{Ca}$ pode ser responsável pela maior via de formação de esteróide na placenta bovina. $\mathrm{O}$ cálcio também pode ter uma importante função na formação de esteróide através da liberação ou utilização do colesterol pela mitocôndria ou por estimular a conversão de pregnenolona para progesterona (HURLEY; DOANE, 1984).

No trabalho de Smaili et al., (2009), os autores indicam que o aumento na concentração de $\mathrm{Ca}$ pode contribuir para o estresse oxidativo e morte celular (apoptose). Vários eventos estão relacionados ao aumento de $\mathrm{Ca}$, incluindo a regulação e ativação de uma série de enzimas dependente de $\mathrm{Ca}$, tais como fosfolípases, proteases e nucleases. Mitocôndrias e retículos endoplasmáticos desempenham um papel crucial na manutenção da homeostase do $\mathrm{Ca}$ intracelular e regulação da morte celular. Várias linhas de evidência têm demonstrado que, na presença de alguns estímulos apoptóticos, a ativação dos processos mitocondriais poderá levar a liberação de citocromo C, seguida da ativação de caspases, fragmentação nuclear de morte celular. No trabalho de Rong e Distelhorst (2008) foi mostrado que em resposta a uma ampla variedade de agentes e condições, sinalização de Ca também pode conduzir à apoptose. 


\subsubsection{Manganês (Mn)}

Avaliou-se o elemento Mn nas regiões da placenta, não foi encontrado distinção entre as regiões coletadas no $\mathrm{GCO}$ aos 225 dias $\left(\mathrm{F}_{2,6}=2.228, \alpha=0.189\right)$. Assumindo o nível de significância de 5\%, as regiões não apresentaram distinção no GCL aos $90\left(\mathrm{~F}_{2,6}=4.80\right.$, $\alpha=0.0568), 135\left(F_{2,7}=1.324, \alpha=0.325\right)$ e 225 dias $\left(F_{2,3}=0.7543, \alpha=0.5428\right)$.

A região PLM apresentou valores significativamente diferentes às regiões IPL e PLC no GCO amostrados aos 90 dias. A região PLM no GCL apresentaram o mesmo comportamento que os animais controle, mas com diferença significativa aos 135 dias $(\mathrm{t}=4.1781$ e $\alpha<0.05)$ (Tabela 9).

Aos 135, a região PLC (Figura 35) dos animais controle mostrou valores significativamente maiores que as regiões IPL (Figura 33) e PLM (Figura 35).

Nos GCO não diferiram nos seus valores em relação ao GCL, em uma mesma região do placentônio e período gestacional (Tabela 9).

No GCO, não houve variação ao longo do período gestacional nas regiões IPL $\mathrm{F}_{2,5}=1.4314, \alpha>0.05$ (Figura 34), PLC $\mathrm{F}_{2,5}=1.5894, \alpha>0.05$ (Figura 35) e PLM F $\mathrm{F}_{2,5}=3.6729$, $\alpha>0.05$ (Figura 36). O GCL também não apresentaram variação ao longo do período gestacional nas regiões IPL $\left(\mathrm{F}_{2,4}=0.1076, \alpha>0.05\right)$, PLC $\left(\mathrm{F}_{2,6}=0.7698, \alpha>0.05\right)$ e PLM $\left(\mathrm{F}_{2,6}=4.127, \alpha>0.05\right)$.

Tabela 9 - Valores de manganês (Mn) $\left(\mu \mathrm{g} \mathrm{g}^{-1}\right)$ para GCO e GCL para as regiões PLC, PLM e IPL Formação dos grupos segundo o teste de Tukey HSD (ANOVA, $\alpha<0.05)$; ns: não significativo $(\alpha>0.05)$. Valor do teste $\mathrm{t}$ para GCO e GCL , localizados na mesma região do placentônio e mesmo período gestacional (90, 135 ou 225 dias), Instituto de Pesquisas Energéticas e Nucleares (IPEN), São Paulo, 2009-2010

\begin{tabular}{lllllll} 
Região & dias & Controle & grupos & Clonados & grupos & t \\
\hline IPL & 90 & $4.165 \pm 0.629$ & $\mathrm{a}$ & $5.147 \pm 1.923$ & $\mathrm{~ns}$ & 0.8207 \\
PLC & & $4.155 \pm 0.361$ & $\mathrm{a}$ & $5.09 \pm 0.581$ & & 2.2189 \\
PLM & $7.185 \pm 0.686$ & $\mathrm{~b}$ & $8.010 \pm 1.091$ & & 1.0376 \\
\hline IPL & 135 & $3.533 \pm 0.465$ & $\mathrm{a}$ & $5.26 \pm 2.235$ & $\mathrm{~ns}$ & 1.0774 \\
PLC & & $5.757 \pm 0.533$ & $\mathrm{~b}$ & $4.845 \pm 1.234$ & & -1.3224 \\
PLM & $4.127 \pm 0.66$ & $\mathrm{a}$ & $6.260 \pm 0.6797$ & & $4.1781^{*}$ \\
\hline IPL & 225 & $3.577 \pm 0.275$ & $\mathrm{~ns}$ & $4.425 \pm 1.874$ & $\mathrm{~ns}$ & 0.6357 \\
PLC & $5.92 \pm 1.739$ & & $5.895 \pm 0.757$ & & -0.022 \\
PLM & $5.477 \pm 1.777$ & & $5.865 \pm 1.237$ & & 0.288 \\
\hline
\end{tabular}

Níveis de significância: *: $\alpha<0.05 ; * * \alpha<0.01 ; * * *: \alpha<0.001$. 


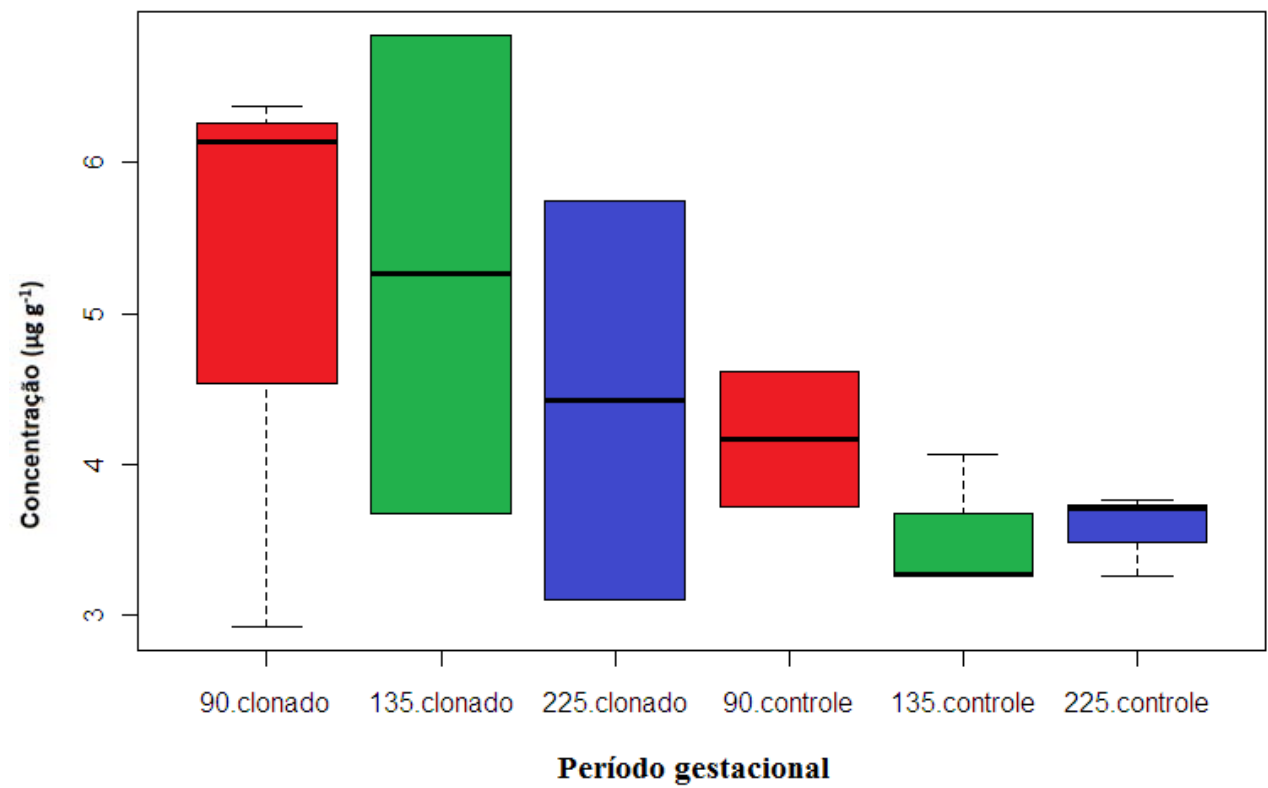

Figura 33 -Diagrama em caixa (boxplot) da concentração de manganês $\left(\mu \mathrm{g} \mathrm{g}^{-1}\right)$ para a região IPL para todos os grupos e períodos gestacionais

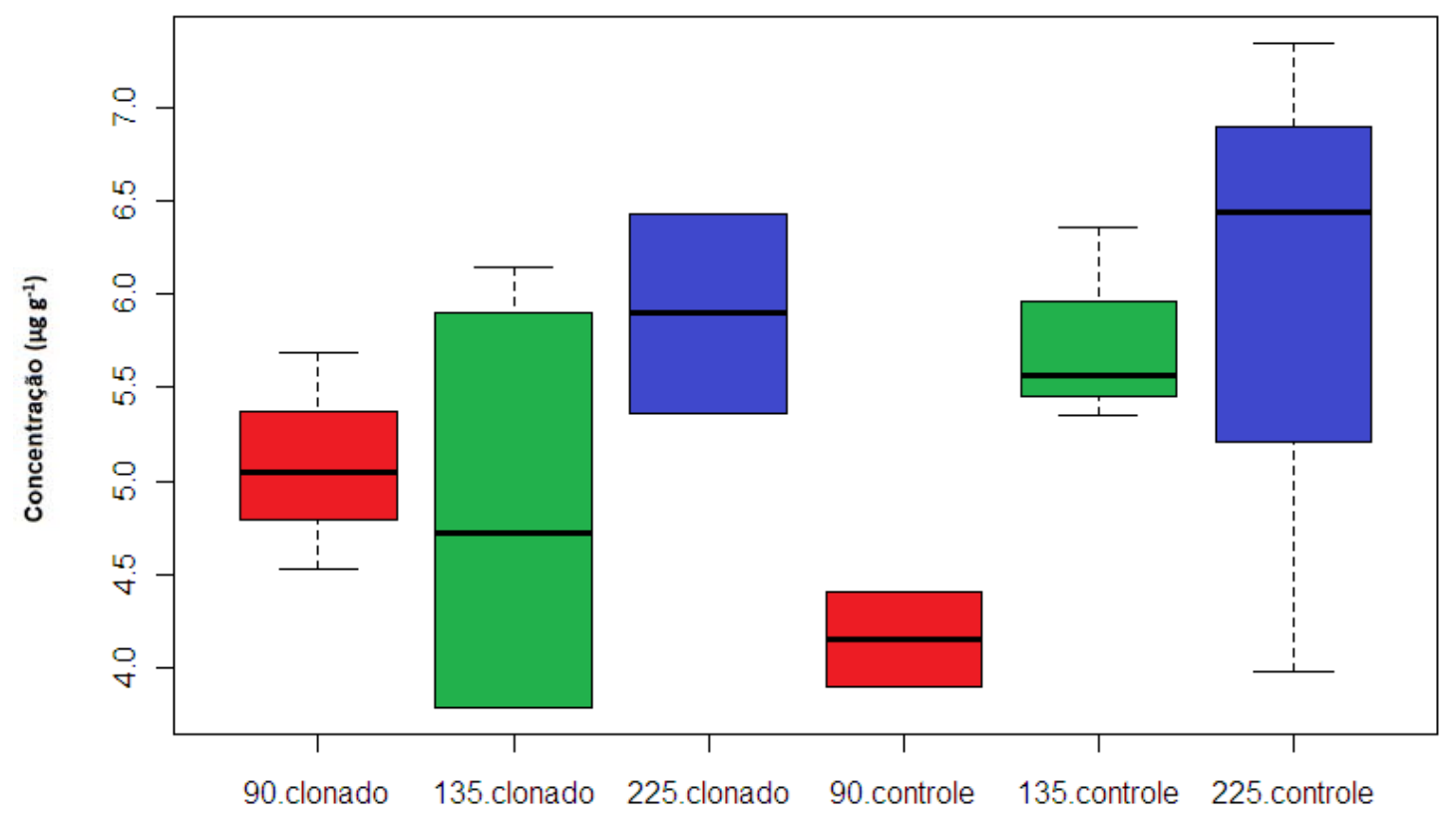

Figura 34 - Diagrama em caixa (boxplot) da concentração de manganês $\left(\mu \mathrm{g} \mathrm{g}^{-1}\right)$ para a região PLC para todos os grupos e períodos gestacionais 


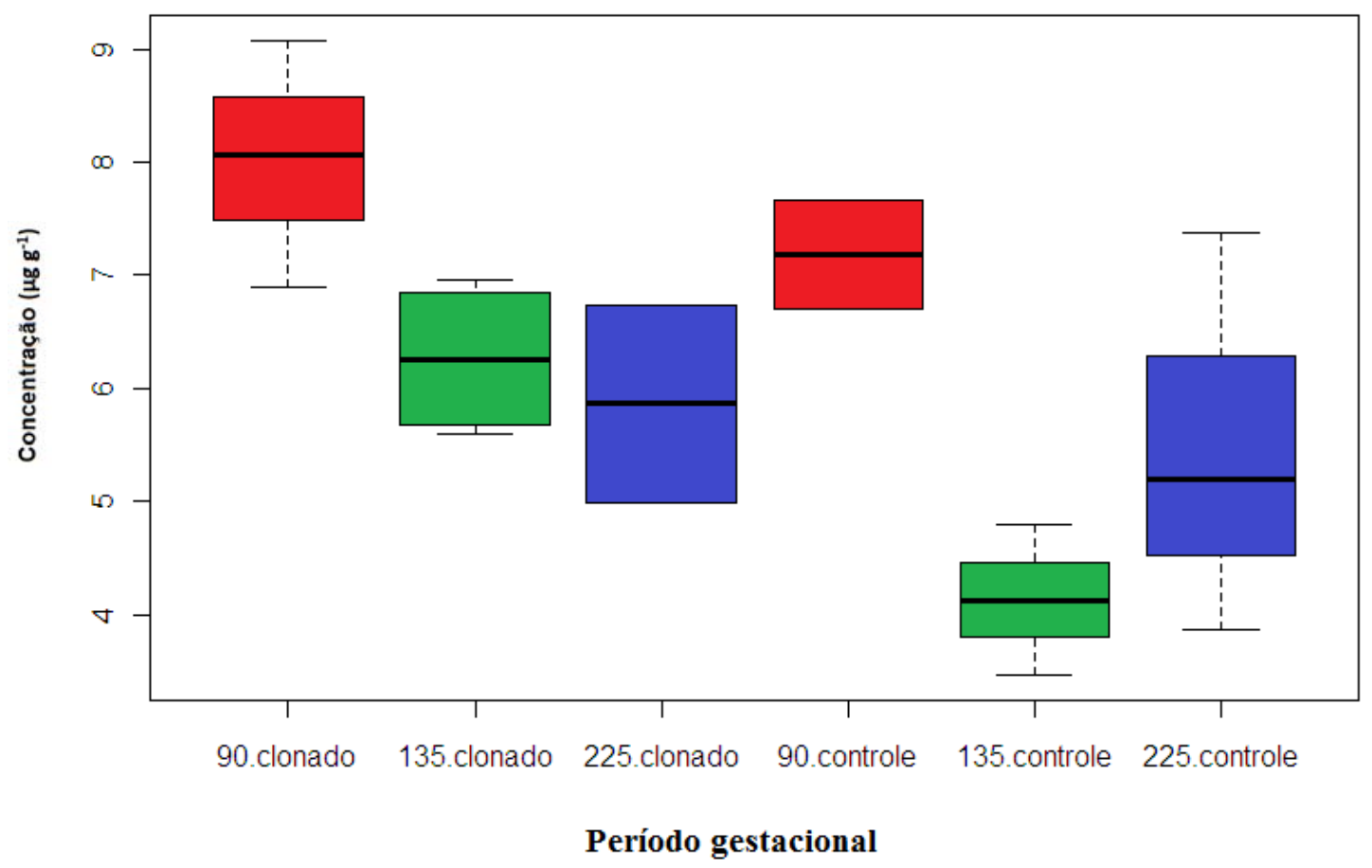

Figura 35 - Diagrama em caixa (boxplot) da concentração de manganês $\left(\mu \mathrm{g} \mathrm{g}^{-1}\right)$ para a região PLM para todos os grupos e períodos gestacionais

A quantidade de Mn necessária para o máximo crescimento e menor para o desenvolvimento normal do esqueleto, e para a reprodução. O Mn atua ativamente nos processos de redução, tecidos respiratórios, formação óssea, crescimento, formação sanguínea (GEORGIEVSKI, 1981). Segundo Lotthammer (1988) o Mn tem uma função na síntese de esteróides, existe uma relação entre a função do Mn e a síntese de colesterol e a fertilidade, já que o colesterol é a substância básica para a progesterona, em seus trabalhos foram observados aumento da incidência de abortos e reduzida taxa de conceptos quando o Mn apresentava menor taxas.

No trabalho de Chornock, Gerrant e Dutcher (1942) ratos alimentados com doses maciças de $\mathrm{Mn}$ (1.73\% da dieta seca) mostraram diminuição intestinal de Ca e P.

O manganês é o elemento traço menos tóxico dos minerais, para aves e mamíferos. Quando há ingestão de grande quantidade de Mn um dos sintomas é a diminuição nos níveis de hemoglobina, antagonismo ao Fe (OLIVEIRA, 2007). Este fato foi observado no estudo 
de Hartman, Matrone e Wise (1955) onde cordeiros com dieta com alto teor de Mn apresentaram baixos níveis de Fe no fígado e na formação de hemoglobina.

\subsubsection{Ferro $(\mathrm{Fe})$}

Avaliou-se o elemento $\mathrm{Fe}$ na diferentes regiões da placenta dos grupos de animais GCL nas fases gestacionais de $90\left(\mathrm{~F}_{2,6}=0.649, \alpha=0.555\right)$ e $225 \operatorname{dias}\left(\mathrm{F}_{2,3}=0.953, \alpha=0.478\right)$, alguma das regiões apresentou-se distinta nos outros grupos amostrados (Tabela 10).

No período gestacional de 90 dias, o GCO na região IPL foi a que apresentou maior concentração de Fe tanto para o GCO e GCL. Aos 135 dias, a região IPL foi a que apresentou maior concentração quando comparadas as outras regiões. Aos 225 dias, a concentração foi maior na região PLM. Os níveis de Fe apresentaram maiores no GCO nas fases gestacionais de 90 e 225 dias.

No entanto os 135 dias, a região PLC $(\mathrm{t}=4.312, \alpha<0.05)$ e PLM $(\mathrm{t}=4.8545, \alpha<0.05)$ apresentaram valores significativamente distintos entre o GCO e GCL, sendo encontrados valores maiores nos animais clonados. Nas outras regiões e períodos gestacionais, os animais clonais e controle não apresentaram valores significativamente distintos (Tabela 10).

Tabela 10 - Valores de ferro $(\mathrm{Fe})\left(\mu \mathrm{g} \mathrm{g}^{-1}\right)$ para GCO e GCL para as regiões PLC, PLM e IPL Formação dos grupos segundo o teste de Tukey HSD (ANOVA, $\alpha<0.05)$; ns: não significativo $(\alpha>0.05)$. Valor do teste t para GCO e GCL, localizados na mesma região do placentônio e mesmo período gestacional (90, 135 ou 225 dias), Instituto de Pesquisas Energéticas e Nucleares (IPEN), São Paulo, 2009-2010

\begin{tabular}{lllllll}
\hline região & dias & Controle & \multicolumn{2}{l}{ grupos } & Clonados & \multicolumn{2}{l}{ grupos } & t \\
\hline IPL & 90 & $107.385 \pm 12.82$ & $\mathrm{a}$ & $86.14 \pm 38.18$ & $\mathrm{~ns}$ & -0.8913 \\
PLC & $61.32 \pm 19.119$ & $\mathrm{~b}$ & $52.16 \pm 7.623$ & & 0.746 \\
PLM & $80.44 \pm 0.707$ & $\mathrm{a}, \mathrm{b}$ & $76.183 \pm 18.425$ & & -0.3997 \\
\hline IPL & 135 & $75.533 \pm 9.517$ & $\mathrm{a}$ & $56,46 \pm 38.178$ & $\mathrm{a}$ & -2.1529 \\
PLC & $55.093 \pm 10.672$ & $\mathrm{a}, \mathrm{b}$ & $84,74 \pm 19.119$ & $\mathrm{~b}$ & $4.312^{*}$ \\
PLM & $45.14 \pm 8.01$ & $\mathrm{~b}$ & $89 \pm 17.058$ & $\mathrm{~b}$ & $4.8545^{*}$ \\
\hline IPL & 225 & $91.825 \pm 61.04$ & $\mathrm{a}$ & $47.557 \pm 4.964$ & $\mathrm{~ns}$ & 1.0233 \\
PLC & $43.16 \pm 0.551$ & $\mathrm{a}$ & $58.5 \pm 6.434$ & & 3.3632 \\
PLM & $109.79 \pm 22.259$ & $\mathrm{~b}$ & $90.267 \pm 23.898$ & & 0.9327 \\
\hline Níveis de significância: $*: \alpha<0.05 ; * * \alpha<0.01 ; * * *: \alpha<0.001$. & &
\end{tabular}


No GCO, a região IPL apresentou diferenças significativas entre todos os períodos gestacionais (Figura 37), havendo decréscimo significativo ao longo do tempo. Na região PLM houve diferença significativa entre os períodos de 135 dias com 225 dias, não sendo encontrada diferença significativa com o período de 90 dias, sendo aos 135 dias, encontrado os menores valores médios de Ferro (Figura 39).

A região PLC do GCL apresentou variação ao longo do período de gestação, sendo significativa a diferença entre o período de 135 dias com os períodos amostrados de 90 e 225 dias, não sendo significativamente distintos estes dois últimos períodos (Figura 38). As regiões IPL $\left(\mathrm{F}_{2,4}=0.4445, \alpha>0.05\right)$ e PLM $\left(\mathrm{F}_{2,6}=2.0081, \alpha>0.05\right)$ não apresentaram variação significativa entre os períodos amostrados para Ferro (Tabela 10).

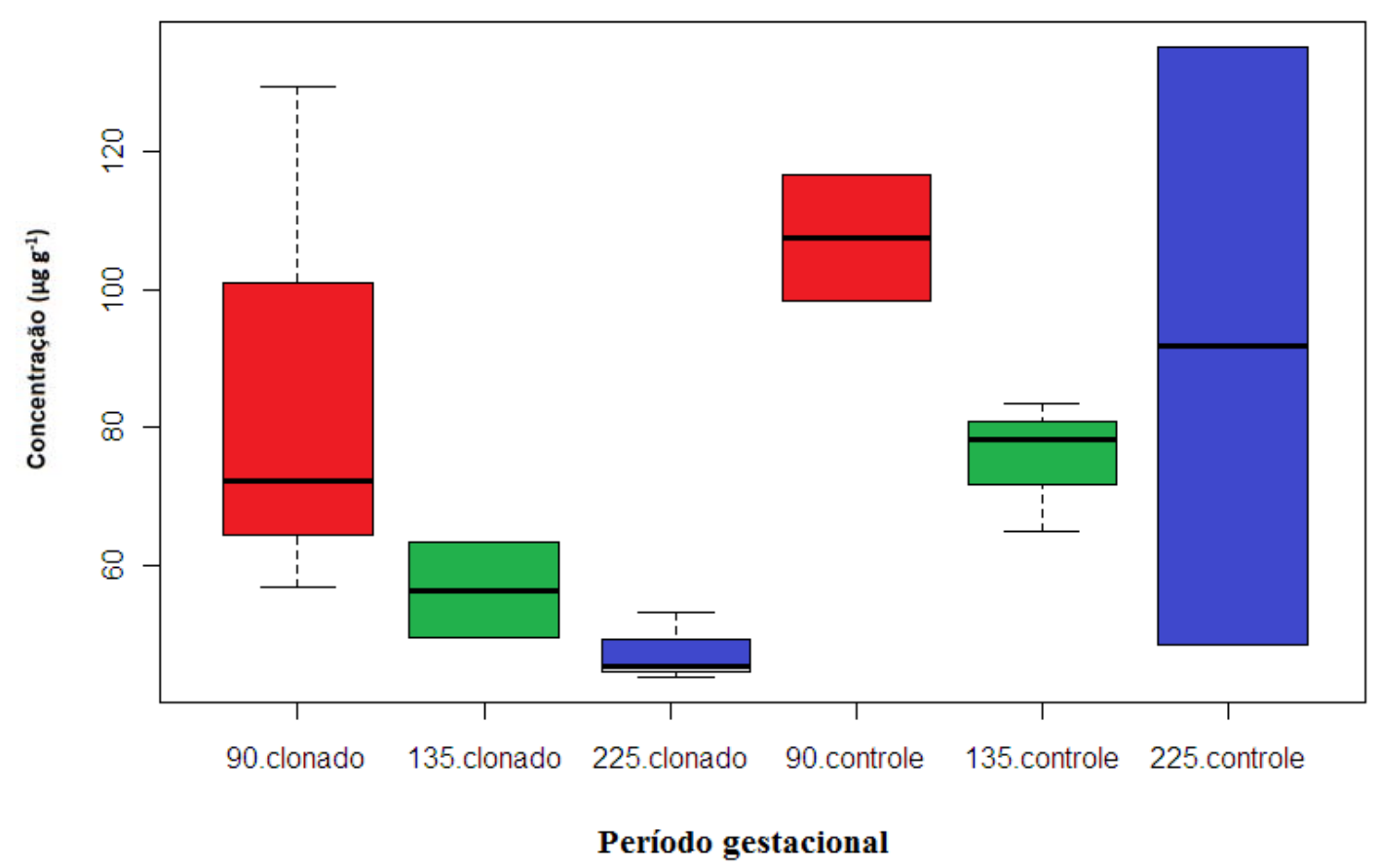

Figura 36 - Diagrama em caixa (boxplot) da concentração de ferro ( $\left.\mu \mathrm{g} \mathrm{g}^{-1}\right)$ para a região IPL para todos os grupos e períodos gestacionais 


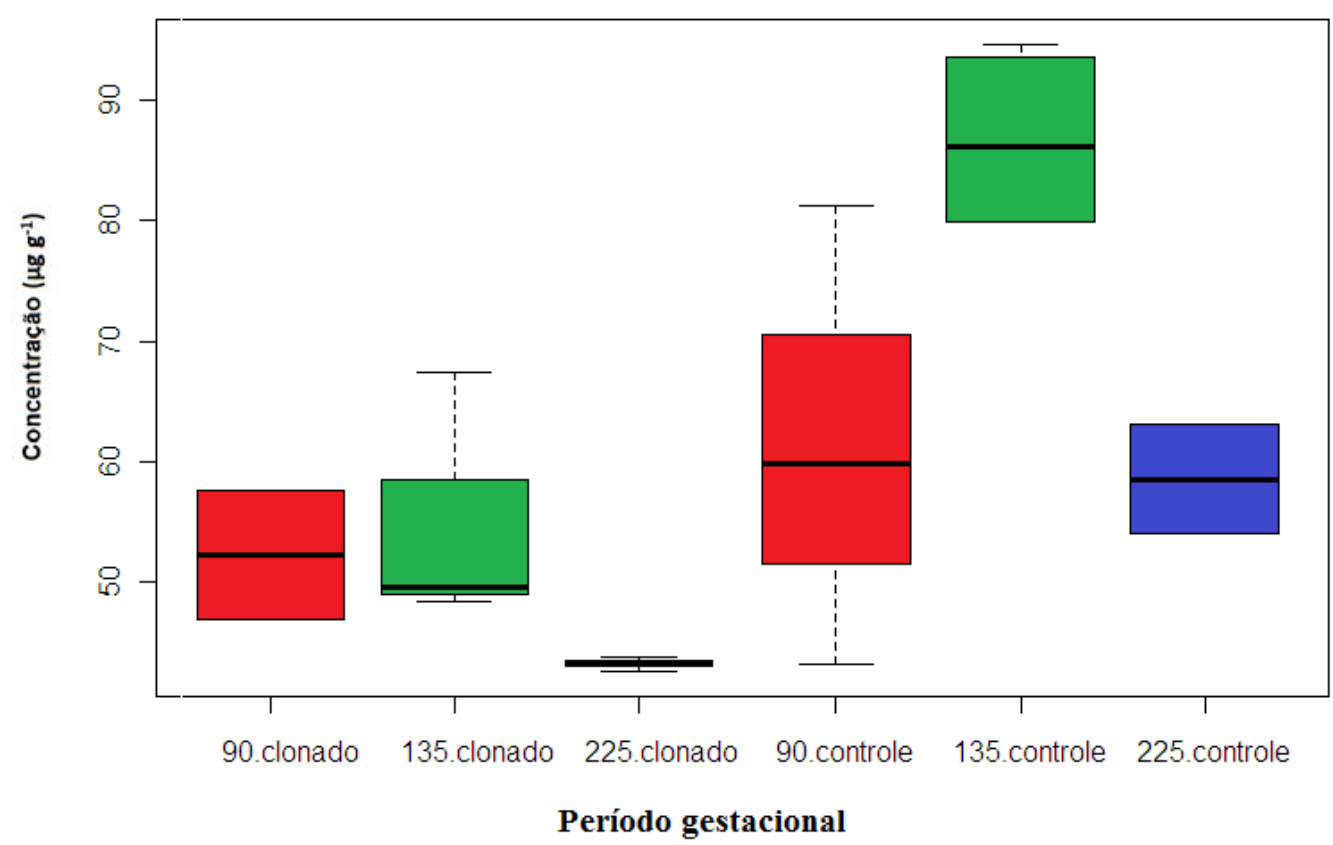

Figura 37 - Diagrama em caixa (boxplot) da concentração de ferro $\left(\mu \mathrm{g} \mathrm{g}^{-1}\right)$ para a região IPL para todos os grupos e períodos gestacionais

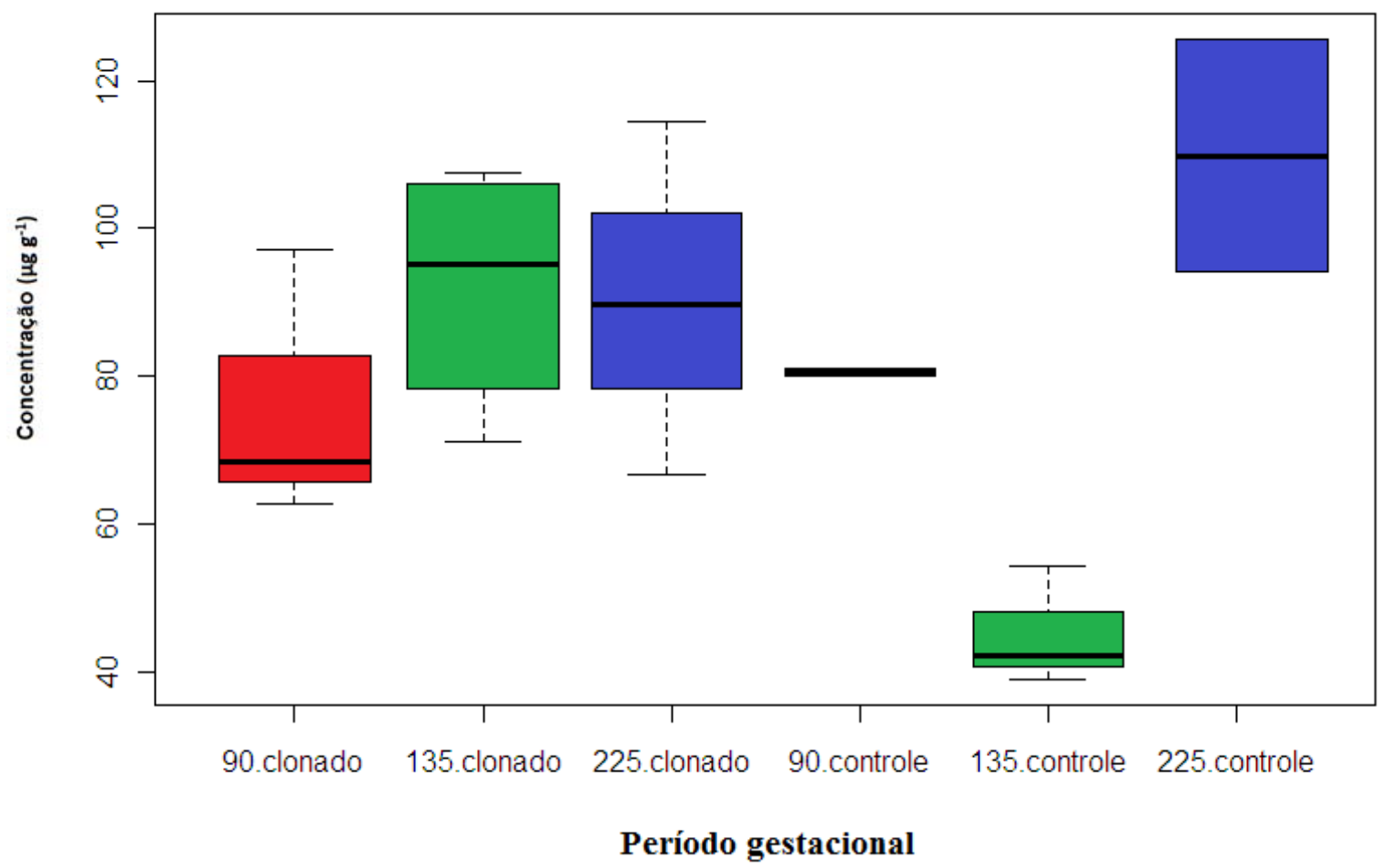

Figura 38 - Diagrama em caixa (boxplot) da concentração de ferro $\left(\mu \mathrm{g} \mathrm{g}^{-1}\right)$ para a região PLM para todos os grupos e períodos gestacionais 
Altos níveis de Fe durante período longo têm influência sobre a disponibilidade do $\mathrm{Cu}$. No trabalho de Enomoto e Hiruma (2001) a transferência de Fe a partir da placenta para o feto é rápida uma vez que a procura de Fe aumenta durante o último período da gravidez. As necessidades de Fe variam, acentuadamente a cada trimestre.

Segundo NRC (1996) altas concentrações de Fe e Zn também reduzem o estado de $\mathrm{Cu}$ e podem aumentar a necessidade de $\mathrm{Cu}$.

Em nosso estudo a região PLM foi a região que apresentou maior concentração de Fe, esta região é caracterizada por apresentarem hematomas placentários, esta região, e chamada de "zona arcada", correspondem a região do topo dos vilos materno, que está em contato com a base dos vilos fetais, possuem um epitélio modificado devido a presença de eritrócitos fagocitados dentro das células epiteliais trofoblásticas e pigmentos hematógenos. Estas estruturas estavam presentes nos trabalhos de Mossman (1987) búfalas Pereira (2004).

No estudo de Walter (2002) ratos recém nascidos com deficiência de ferro, apresentaram controle respiratório mitocondrial menor, um aumento dos níveis de leucócitos oxidantes em polimorfonucleases, baixou o controle respiratório, e algumas deformações mitocondriais ocorreram. Tanto a deficiência de ferro quanto o excesso causam estresse oxidativo, causando disfunções mitocondriais. $\mathrm{O}$ excesso de $\mathrm{Fe}$ inibe a absorção de $\mathrm{Ca}$, pois os dois competem pelo mesmo sítio de transferência.

\subsubsection{Cobre $(\mathrm{Cu})$}

Avaliou-se a concentração de $\mathrm{Cu}$ nas diferentes regiões da placenta, com exceção do GCO aos 135 dias (Tabela 11), os tratamentos mostraram indistinção nos valores de cobre entre as diferentes regiões, tanto o GCO amostrados aos $90\left(\mathrm{~F}_{2,3}=8.077, \alpha=0.062\right) \mathrm{e}$ aos $225 \operatorname{dias}\left(\mathrm{F}_{2,6}=1.183, \alpha=0.369\right)$, e entre o GCL aos $90\left(\mathrm{~F}_{2,6}=0.595, \alpha=0.581\right), 135$ $\left(F_{2,7}=3.599, \alpha=0.084\right)$ e $225 \operatorname{dias}\left(F_{2,3}=0.282, \alpha=0.772\right)$.

O GCO na fase gestacional de 135 dias apresentou diferenças significativas entre as regiões PLC (Figura 41) IPL (Figura 40) e PLM (Figura 42).O GCO não diferiu nos seus valores em relação ao GCL, em uma mesma região do placentônio e período gestacional (Tabela 11). 
Tabela 11 - Valores de cobre $(\mathrm{Cu})\left(\mu \mathrm{g} \mathrm{g}^{-1}\right)$ para GCO e GCL para as regiões PLC, PLM e IPL Formação dos grupos segundo o teste de Tukey HSD (ANOVA, $\alpha<0.05)$; ns: não significativo $(\alpha>0.05)$. Valor do teste t para GCO e GCL, localizados na mesma região do placentônio e mesmo período gestacional (90, 135 ou 225 dias), Instituto de Pesquisas Energéticas e Nucleares (IPEN), São Paulo, 2009-2010.

\begin{tabular}{lllllll}
\hline região & dias & Controle & grupos & Clonados & grupos & t \\
\hline IPL & 90 & $25.905 \pm 1.407$ & $\mathrm{~ns}$ & $26.17 \pm 1.675$ & $\mathrm{~ns}$ & 0.191 \\
PLC & & $28.895 \pm 4.943$ & & $30.030 \pm 4.791$ & & 0.2546 \\
PLM & $37.72 \pm 1.273$ & & $29.557 \pm 6.421$ & & -2.14 \\
\hline IPL & 135 & $21.64 \pm 4.328$ & $\mathrm{a}$ & $27.34 \pm 1.131$ & $\mathrm{~ns}$ & 2.1725 \\
PLC & $33.147 \pm 2.268$ & $\mathrm{~b}$ & $33.177 \pm 3.621$ & & 0.0138 \\
PLM & $26.533 \pm 3.582$ & $\mathrm{a}, \mathrm{b}$ & $27.525 \pm 3.447$ & & 0.3683 \\
\hline IPL & 225 & $27.323 \pm 2.744$ & $\mathrm{~ns}$ & $26.18 \pm 1.612$ & $\mathrm{~ns}$ & 0.099 \\
PLC & $27.030 \pm 2.797$ & & $27.725 \pm 3.486$ & & 0.2365 \\
PLM & $23.797 \pm 2.349$ & & $28.065 \pm 2.595$ & & 1.8707 \\
\hline
\end{tabular}

Níveis de significância: *: $\alpha<0.05 ; * * \alpha<0.01 ; * * *: \alpha<0.001$.

Foi encontrada diferença significativa na região PLM entre os valores de 225 e 135 dias com o período de 90 dias, onde foram encontrados os maiores valores de Cobre (Figura 41) para o GCO. As regiões IPL $\left(\mathrm{F}_{2,5}=1.6009, \alpha>0.05\right)$ e PLC $\left(\mathrm{F}_{2,5}=2.9096, \alpha>0.05\right)$ não apresentaram variação significativa entre os períodos gestacionais.

No GCL não foram encontradas diferenças significativas entre os períodos gestacionais nas regiões IPL $\left(\mathrm{F}_{2,4}=0.4093, \alpha>0.05\right)$, PLC $\left(\mathrm{F}_{2,6}=1.3299, \alpha>0.05\right)$ e PLM $\left(F_{2,6}=0.1741, \alpha>0.05\right)$, não havendo variação ao longo da gestação. 


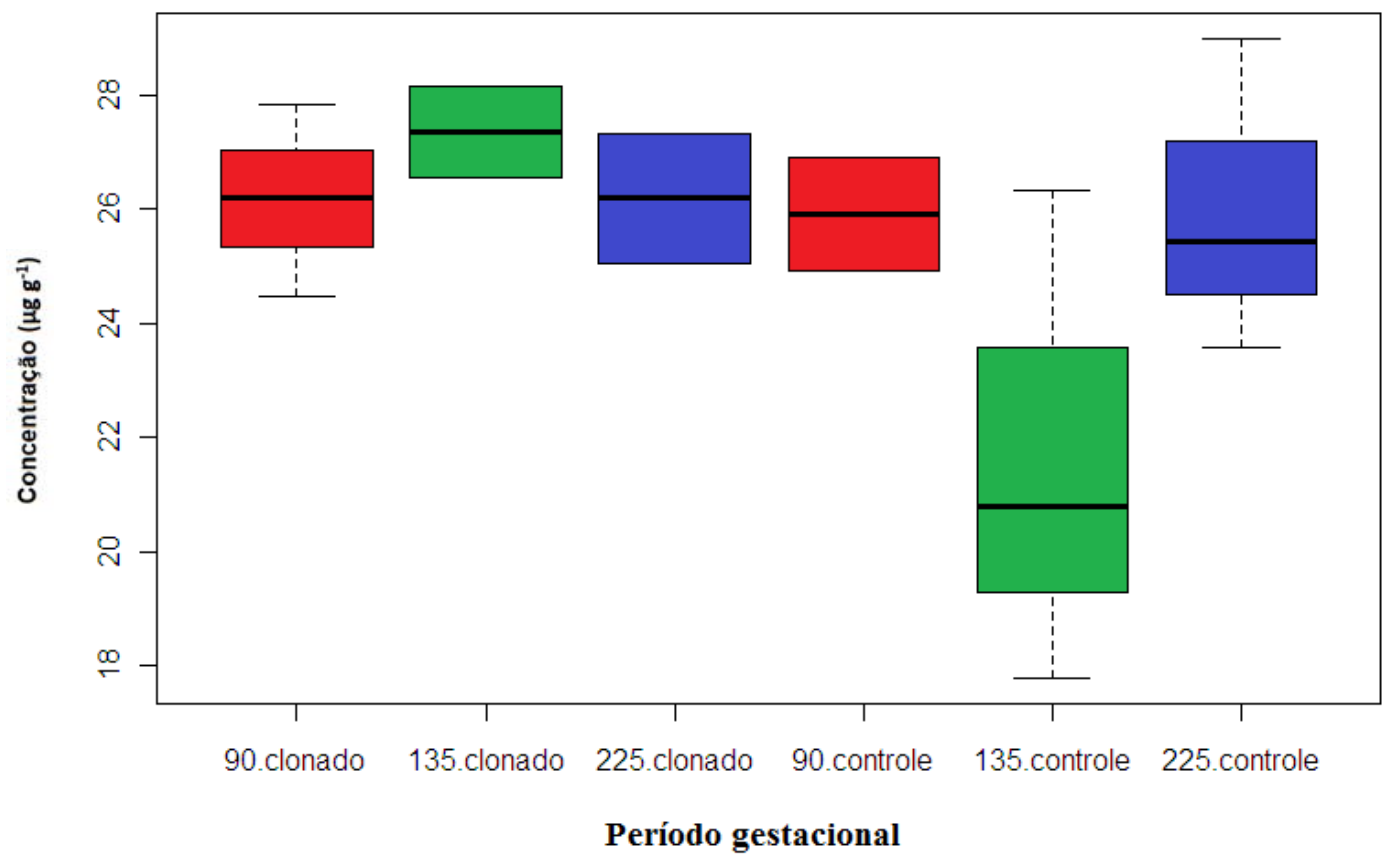

Figura 39 - Diagrama em caixa (boxplot) da concentração de cobre $\left(\mu \mathrm{g} \mathrm{g}^{-1}\right)$ para a região IPL para todos os grupos e períodos gestacionais

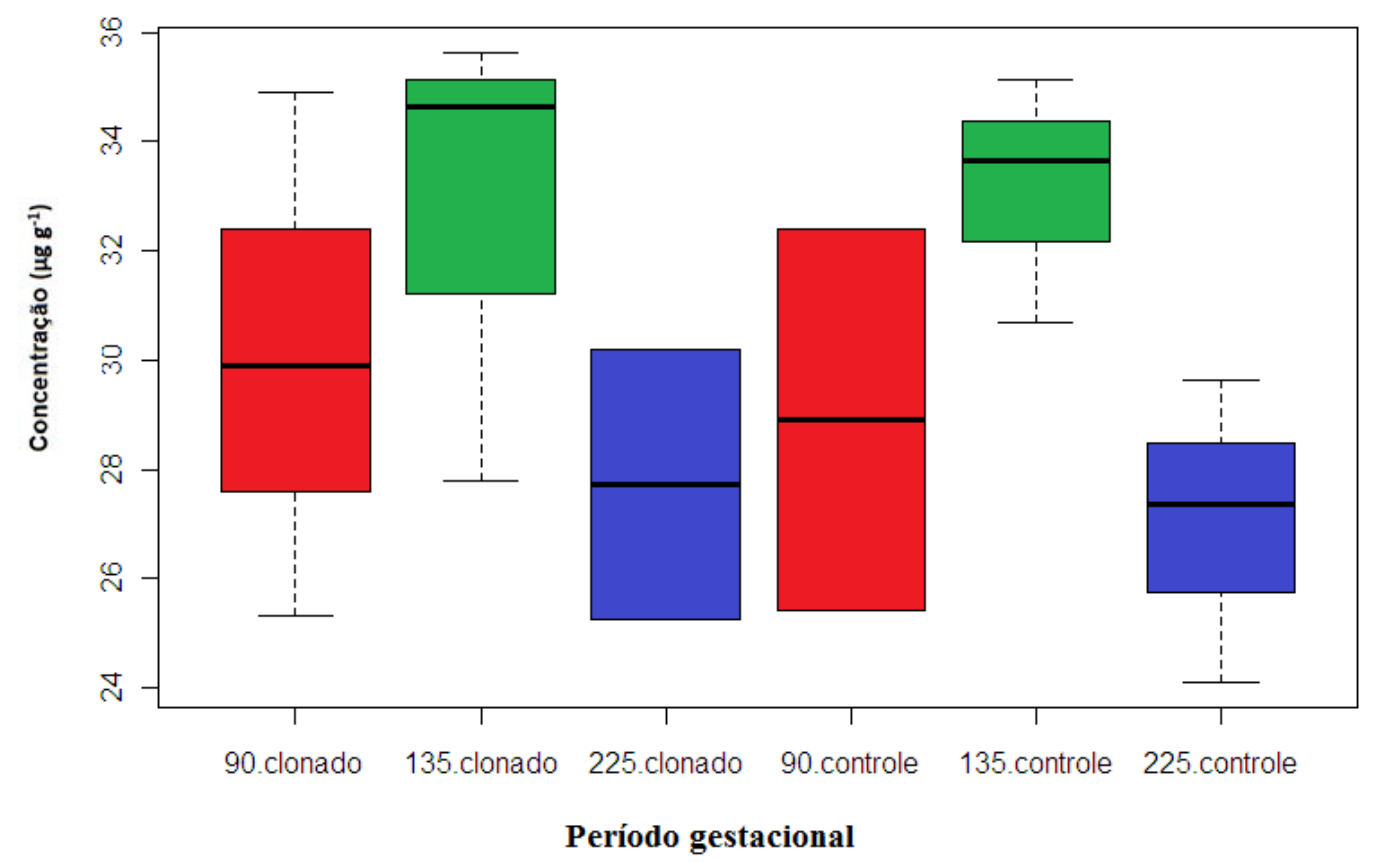

Figura 39 - Diagrama em caixa (boxplot) da concentração valores de cobre $\left(\mu \mathrm{g} \mathrm{g}^{-1}\right)$ para a região PLC para todos os grupos e períodos gestacionais 


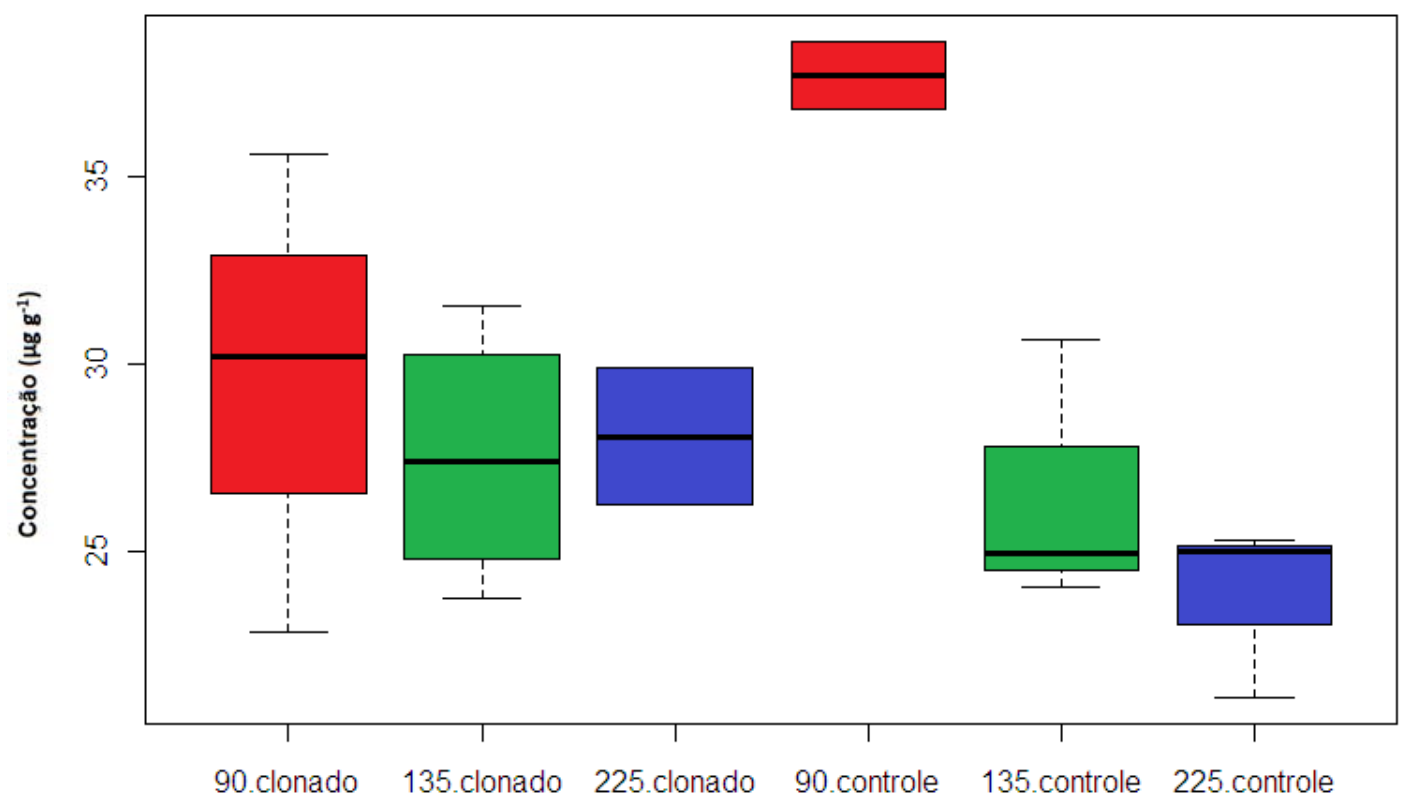

Figura 40 - Diagrama em caixa (boxplot) da concentração valores de cobre $\left(\mu \mathrm{g} \mathrm{g}^{-1}\right)$ para a região PLM para todos os grupos e períodos gestacionais

\subsubsection{Zinco (Zn)}

A concentração de Zn mensurada com exceção do GCO na fase gestacional aos 90 dias, não apresentaram diferenças significativas nos valores entre as diferentes regiões (Tabela 12), tanto o GCO amostrados aos $135\left(\mathrm{~F}_{2,6}=2.412, \alpha=0.17\right), 225$ dias $\left(\mathrm{F}_{2,6}=0.885\right.$, $\alpha=0.461)$, e entre o GCL aos $90\left(F_{2,6}=0.078, \alpha=0.926\right), 135\left(F_{2,7}=3.645, \alpha=0.082\right)$ e 225 dias $\left(\mathrm{F}_{2,3}=0.5025, \alpha=0.648\right)$.

O GCO aos 90 dias mostraram diferenças significativas entre PLC (Figura 43), IPL (Figura 42) e PLM (Figura 44). Os grupos CO não diferiram nos seus valores em relação ao GCL, em uma mesma região do placentônio e período gestacional (Tabela 12). 
Tabela 12 - Valores de zinco $(\mathrm{Zn})\left(\mu \mathrm{g} \mathrm{g}^{-1}\right)$ para GCO e GCL para as regiões PLC, PLM e IPL Formação dos grupos segundo o teste de Tukey HSD (ANOVA, $\alpha<0.05)$; ns: não significativo $(\alpha>0.05)$. Valor do teste t para GCO e GCL, localizados na mesma região do placentônio e mesmo período gestacional (90, 135 ou 225 dias), Instituto de Pesquisas Energéticas e Nucleares (IPEN), São Paulo, 2009-2010

\begin{tabular}{lllllll}
\hline região & dias & Controle & grupos & Clonados & grupos & T \\
\hline IPL & 90 & $18.24 \pm 2.192$ & $\mathrm{a}$ & $42.443 \pm 27.252$ & $\mathrm{~ns}$ & 1.5309 \\
PLC & & $46.42 \pm 10.225$ & $\mathrm{~b}$ & $48.437 \pm 10.93$ & & 0.2101 \\
PLM & $61.965 \pm 2.10$ & $\mathrm{~b}$ & $43.030 \pm 20.009$ & & -1.626 \\
\hline IPL & 135 & $42.517 \pm 23.446$ & $\mathrm{~ns}$ & $44.925 \pm 6.626$ & $\mathrm{~ns}$ & 0.1681 \\
PLC & & $59.697 \pm 1.00$ & & $57.137 \pm 9.237$ & & -0.55 \\
PLM & $35.393 \pm 5.639$ & & $38.255 \pm 11.499$ & & 0.4331 \\
\hline IPL & 225 & $47.748 \pm 18.629$ & $\mathrm{~ns}$ & $47.885 \pm 15.902$ & $\mathrm{~ns}$ & 0.0269 \\
PLC & $42.510 \pm 7.269$ & & $44.545 \pm 13.131$ & & 0.1997 \\
PLM & $34.113 \pm 7.973$ & & $35.815 \pm 6.201$ & & 0.2676 \\
\hline
\end{tabular}

Níveis de significância: *: $\alpha<0.05 ; * * \alpha<0.01 ; * * *: \alpha<0.001$.

Para os animais controle, a região IPL $\left(\mathrm{F}_{2,5}=1.5434, \alpha>0.05\right)$ não apresentou variação nos seus valores ao longo dos períodos gestacionais (Figura 42). Mas a região PLC mostrou pequena diferença entre os valores do período de 225 e 135 dias, mas não foram encontradas diferenças significativas entre o período de 90 dias com os outros dois períodos (Figura 43).

Nos animais clonados não foram encontradas diferenças significativas entre os períodos gestacionais nas regiões IPL $\left(\mathrm{F}_{2,4}=0.04, \alpha>0.05\right)$, PLC $\left(\mathrm{F}_{2,6}=1.1329, \alpha>0.05\right)$ e PLM $\left(\mathrm{F}_{2,6}=0.1709, \alpha>0.05\right)$, não havendo variação ao longo da gestação (Figura 44). 


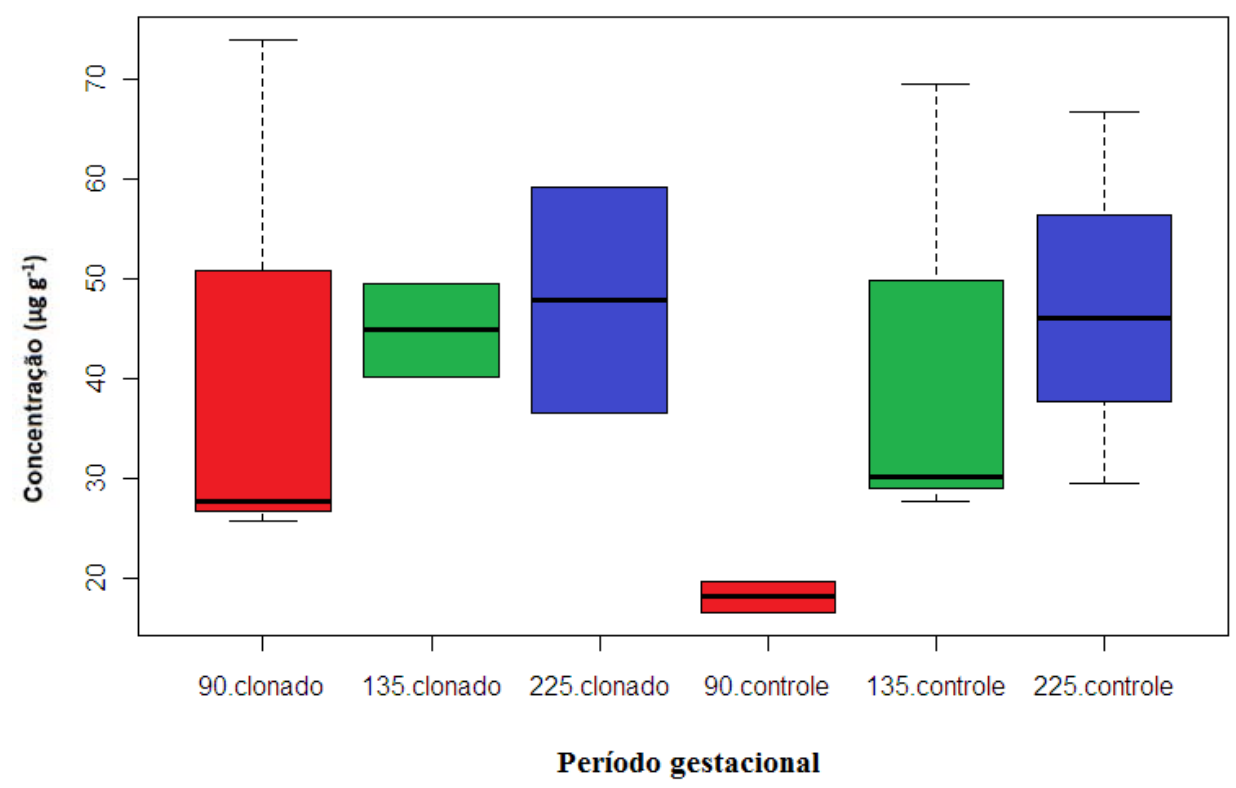

Figura 41 - Diagrama em caixa (boxplot) da concentração valores de zinco $\left(\mu \mathrm{g} \mathrm{g}^{-1}\right)$ para a região IPL para todos os grupos e períodos gestacionais

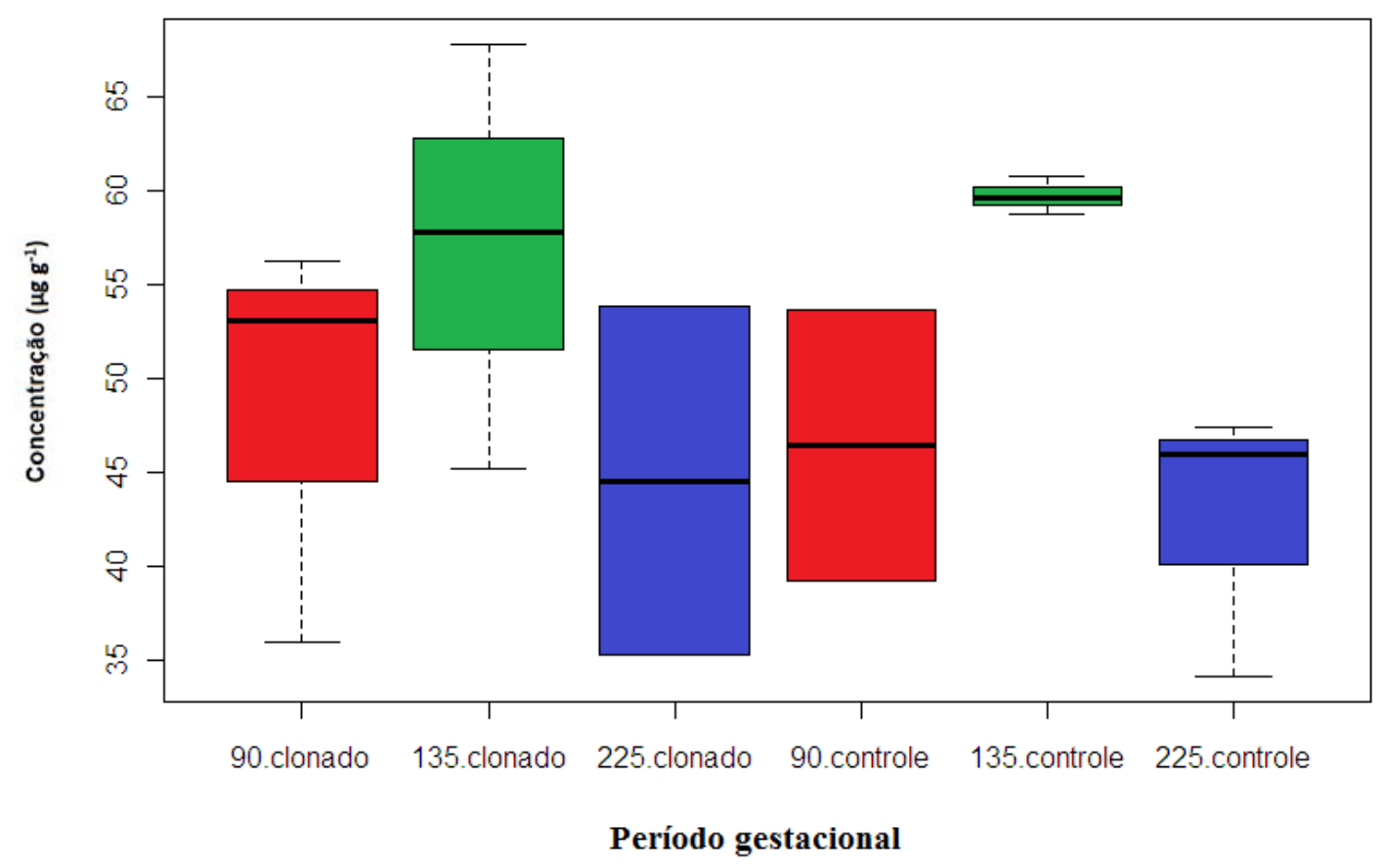

Figura 42- Diagrama em caixa (boxplot) da concentração valores de zinco $\left(\mu \mathrm{g} \mathrm{g}^{-1}\right)$ para a região PLC para todos os grupos e períodos gestacionais 


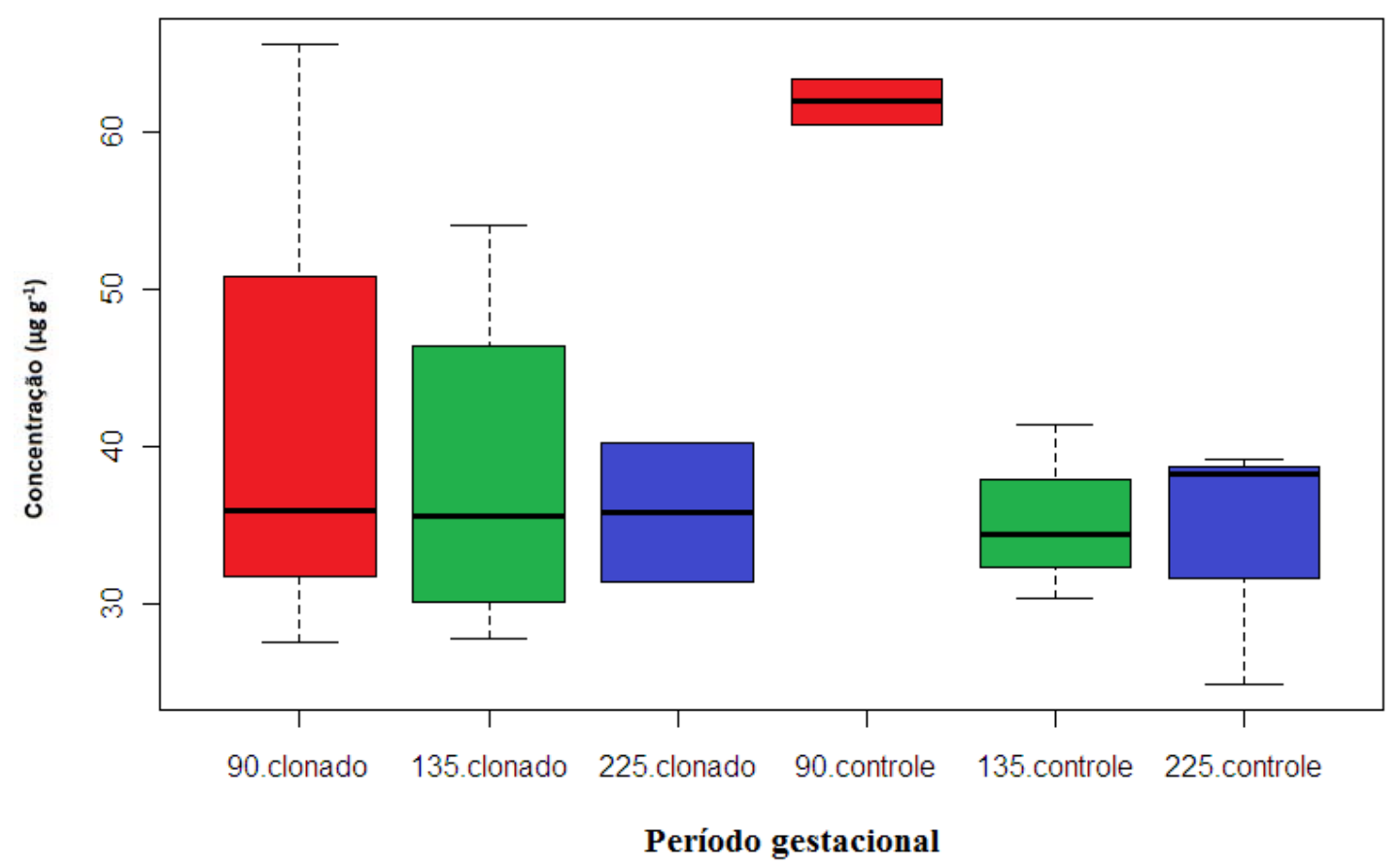

Figura 43 - Diagrama em caixa (boxplot) da concentração valores de zinco $\left(\mu \mathrm{g} \mathrm{g}^{-1}\right)$ para a região PLM para todos os grupos e períodos gestacionais

A placenta de diversas espécies de animais representa um órgão para troca de nutrientes entre a mãe e o feto. Estudos mostram que a carência mineral estão entre os fatores que mais contribuem para a baixa produtividade do rebanho.

Uma grande parte da mortalidade embrionária bovina ocorre em fêmeas saudáveis em decorrência de uma comunicação materna embrionária deficiente, que impedem a gestação (WOLF et al., 2003). O alto índice de mortalidade embrionária e fetal no terço inicial da gestação de bovino é uma das maiores causas de perdas econômicas na produção animal.

O cálcio, magnésio, fósforo e algumas forma de sulfato são também importantes é considerados macronutrientes, todos são necessários a muitos processos fisiológicos. Qualquer grande alteração nas suas concentrações é deletéria ou fatal (SUTTER, 1989).

Há evidência crescente de que muitos defeitos no desenvolvimento embrionário ou fetal podem ser causados por aporte deficiente de nutrientes, tais como cobre, iodo, ferro, magnésio e zinco (KEEN et al., 1998). 
Alguns minerais influenciam diretamente na produção hormonal: a síntese de progesterona, necessária pelo menos durante o terço inicial da gestação na maioria dos mamíferos (HAFEZ,1982), pode ser afetada por Ca, Zn e Mg.

No estudo de Almed et al., (2009) as concentrações de Zn, Cu, Fe e Se apresentaramse baixas em búfalas com retenção de placenta.

No estudo de Enomoto e Hiruma (2001) as concentrações de $\mathrm{Mg}$ e Se foram significativamente maiores no grupo de bebês que apresentaram restrição de crescimento uterino.

Os resultados apresentados para o selênio na literatura mostraram-se contraditórios. Pretende-se realizar experimentos posteriormente visando mensurar as alterações na concentração de Se para a retenção placentária e animais com restrição de crescimento uterino. Essa comparação permitirá confrontarmos esses resultados com apresentados na literatura. 


\subsection{MAPAS BIDIMENSIONAIS DA CONCENTRAÇÃO ELEMENTAR EM PLACENTA DE BOVINO $\mu$ XRF}

Nos mapas de distribuição das concentrações dos elementos, as áreas em vermelho indicam maior intensidade. Os mapas de distribuição das concentrações de P, S, Cl, K, Mn, $\mathrm{Ca}, \mathrm{Fe}, \mathrm{Cu}, \mathrm{Zn}, \mathrm{Se}, \mathrm{Br}$ e Rb estão representados nas Figuras 47 a 53, respectivamente. Nestes mapas, as cores indicam o gradiente de concentração dos elementos, sendo que período gestacional foi representado por uma única amostra. No total avaliou-se três amostras para cada grupo distinto, sendo que todas as amostras apresentaram o mesmo comportamento de distribuição de elementos independente da fase gestacional. Nesse experimento selecionouse as áreas das amostras de maior interesse.

$\mathrm{Na}$ figura 45, visualiza-se as regiões selecionadas para o mapeamento. Na figura 46 apresenta-se como exemplo os perfis que podem ser obtidos para as amostras.

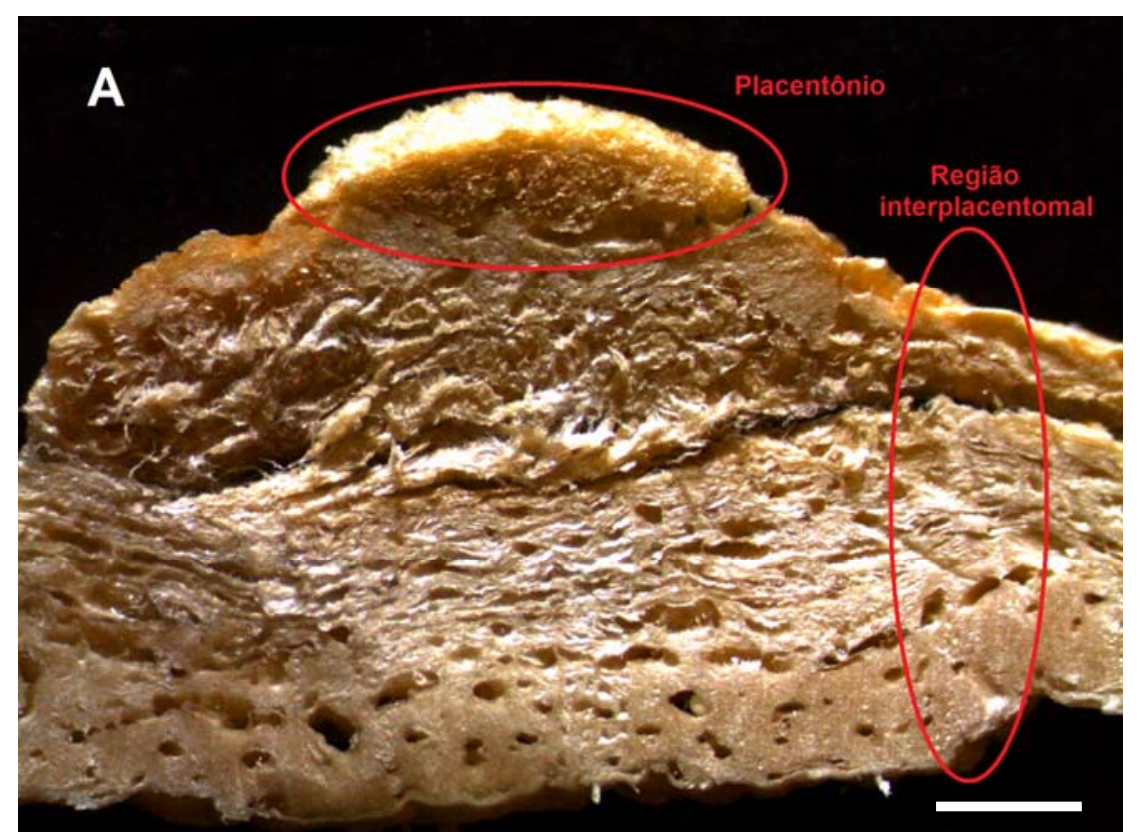

Figura 44 - Esquema ilustrativo da amostra de placenta bovina apresenta-se detalhe da área mapeada circulada em vermelho. Barra: $1 \mathrm{~cm}$ 
Perfis - Amostra de Placentônio
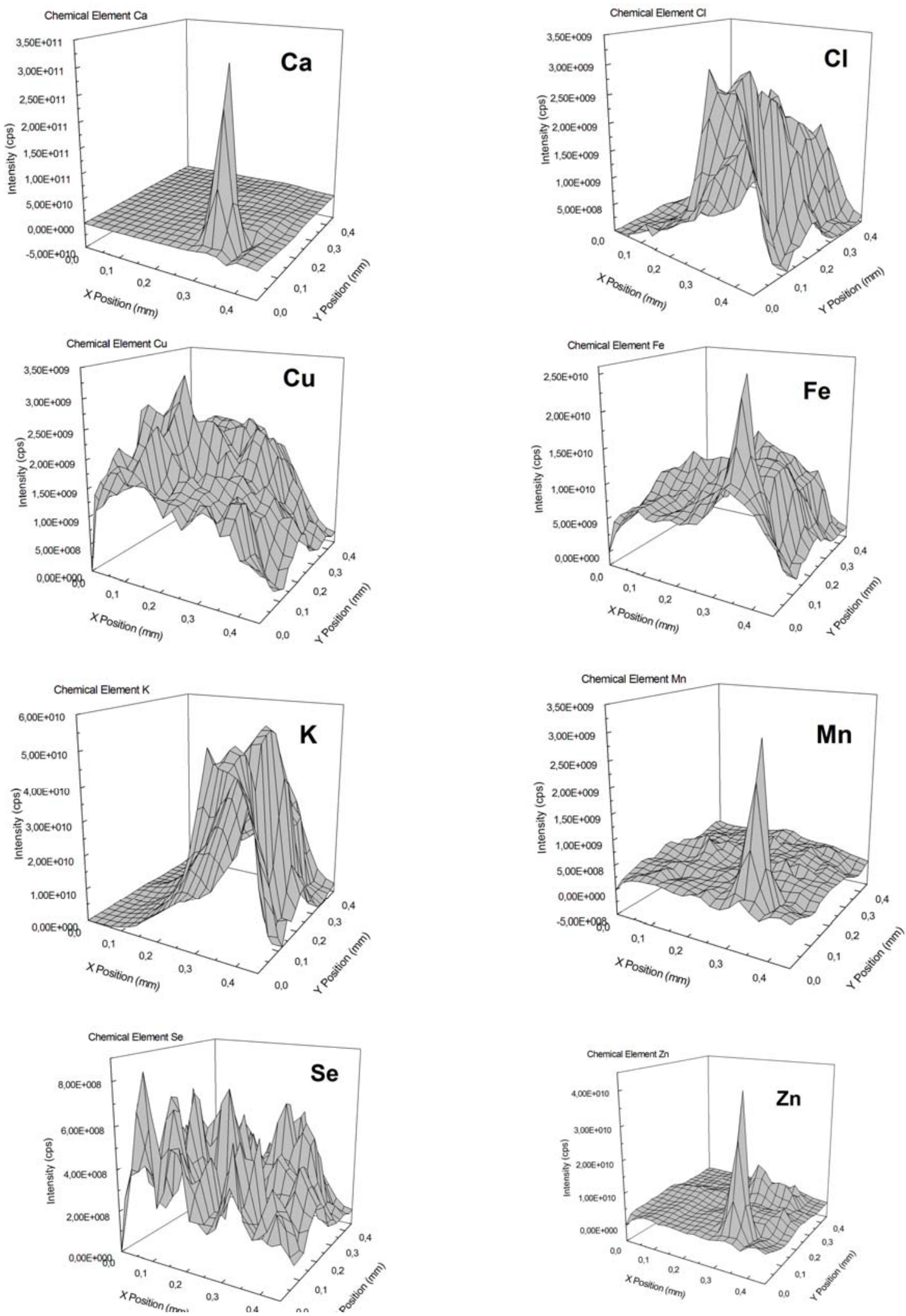

Figura 45 - Exemplos de perfis adquiridos para uma amostra de placentônio bovino 

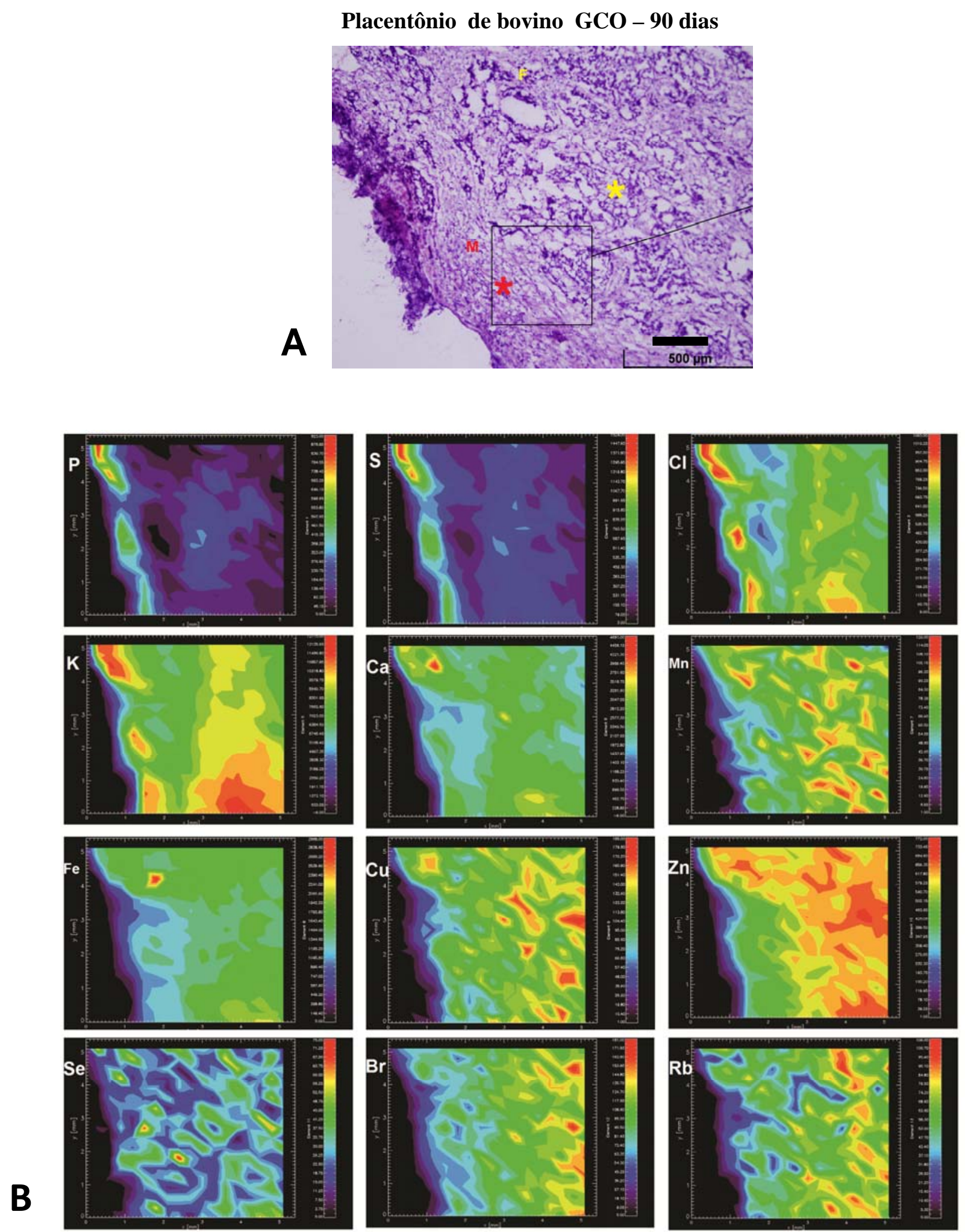

Figura 46 - (A) Fotomicrografia de placentônio bovino GCO 90 dias de gestação *vermelho (epitélio materno) e *amarelo (epitélio fetal). Mapeamento bidimensional da concentração elementar em amostra de placentônio por $\mu$ XRF. Barra $500 \mu \mathrm{m}$ 
Placentônio de bovino GCL 90 dias
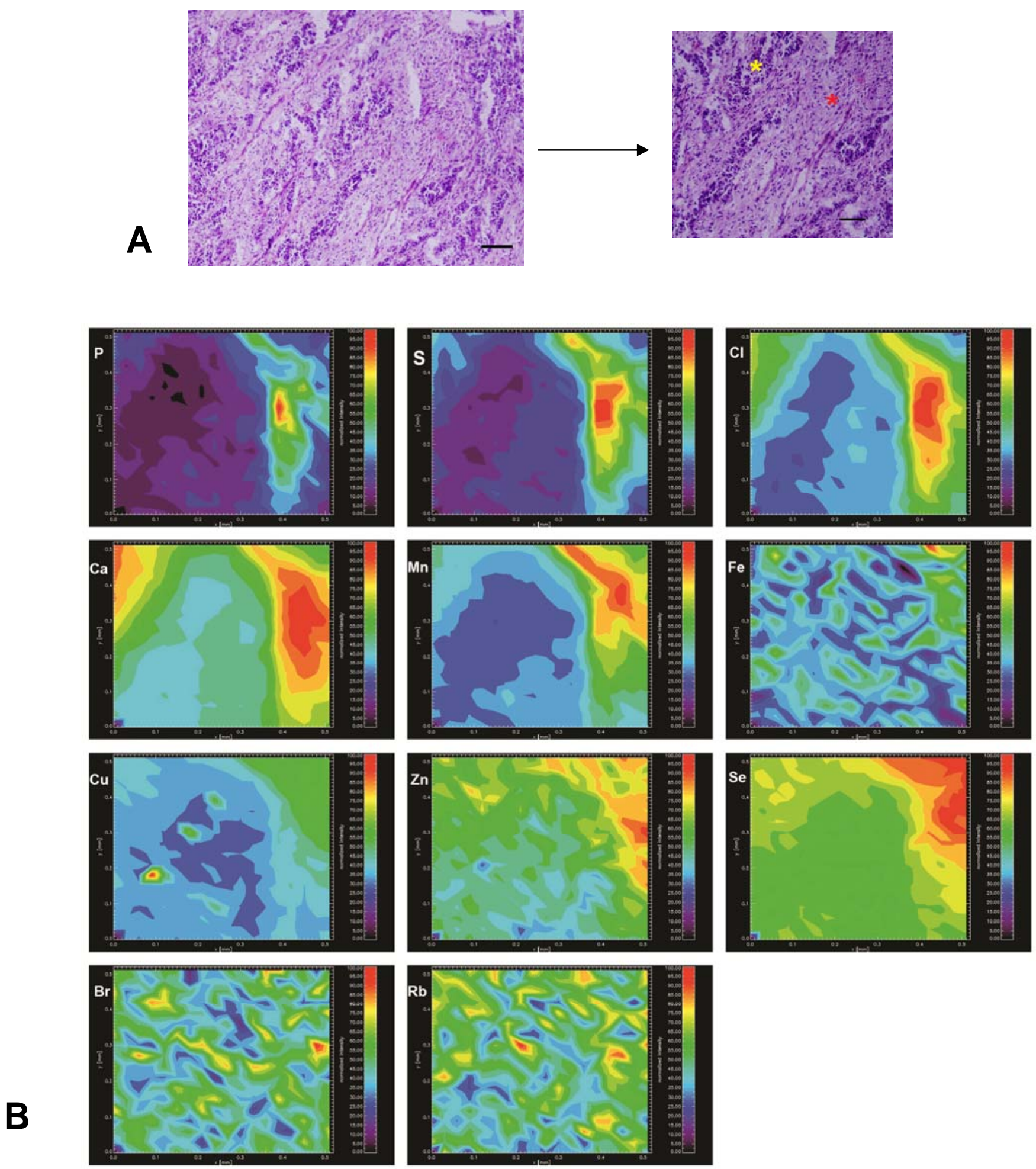

Figura 47 - (A) Fotomicrografia de placentônio bovino GCL com 90 dias de gestação, *vermelho (epitélio materno) e *amarelo (epitélio fetal). (B) Mapeamento bidimensional da concentração elementar em amostra de placentônio por $\mu$ XRF. Barra: (A) $500 \mu \mathrm{m}, 200 \mu \mathrm{m}$ 


\section{Placentônio de bovino GCO 135 dias}
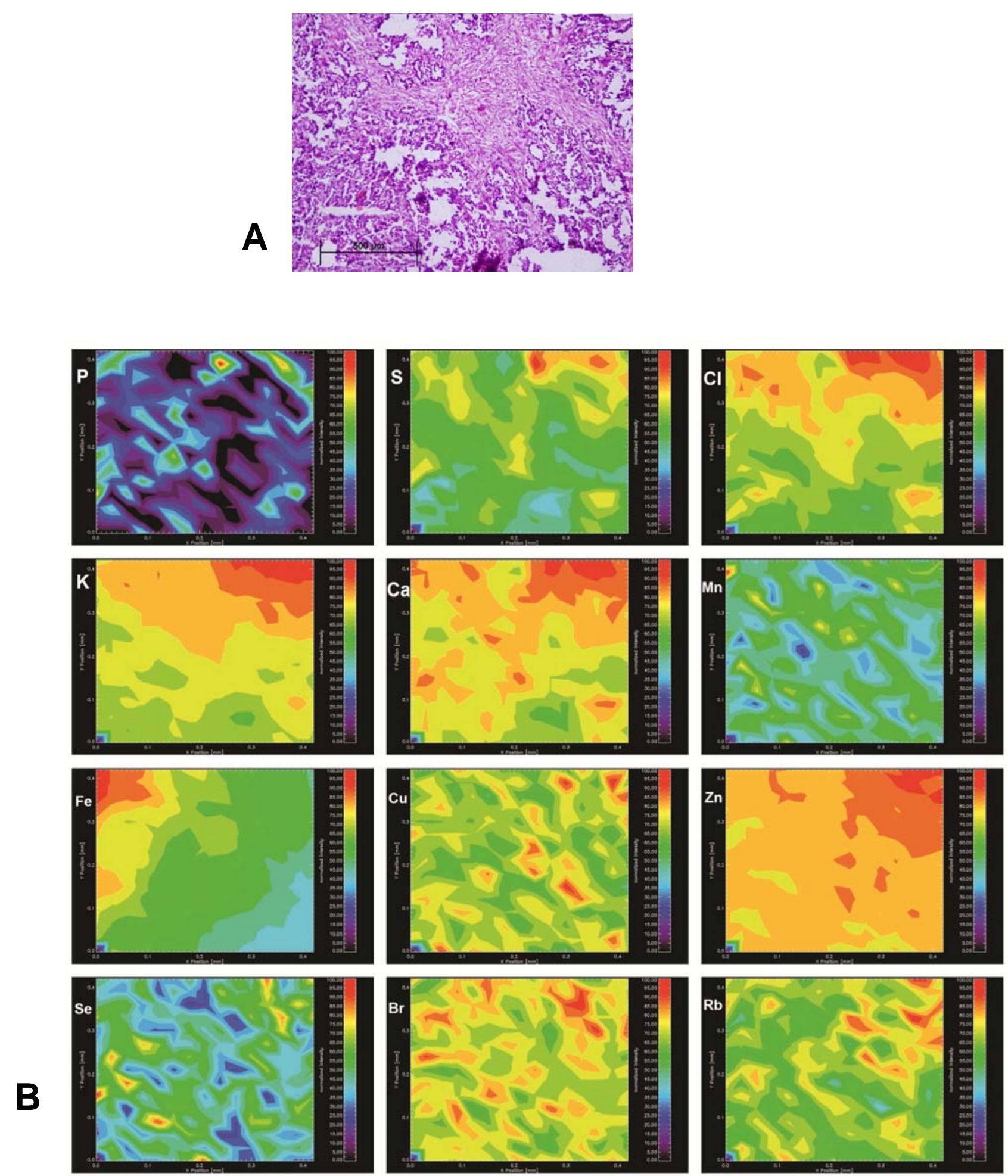

Figura 48 - (A) Fotomicrografia de placentônio bovino GCO 135 dias de gestação, *vermelho (epitélio materno) e *preto (epitélio fetal). (B) Mapeamento bidimensional da concentração elementar em amostra de placentônio por $\mu$ XRF. Barra: $500 \mu \mathrm{m}$ 
Placentônio de bovino GCL 135 dias
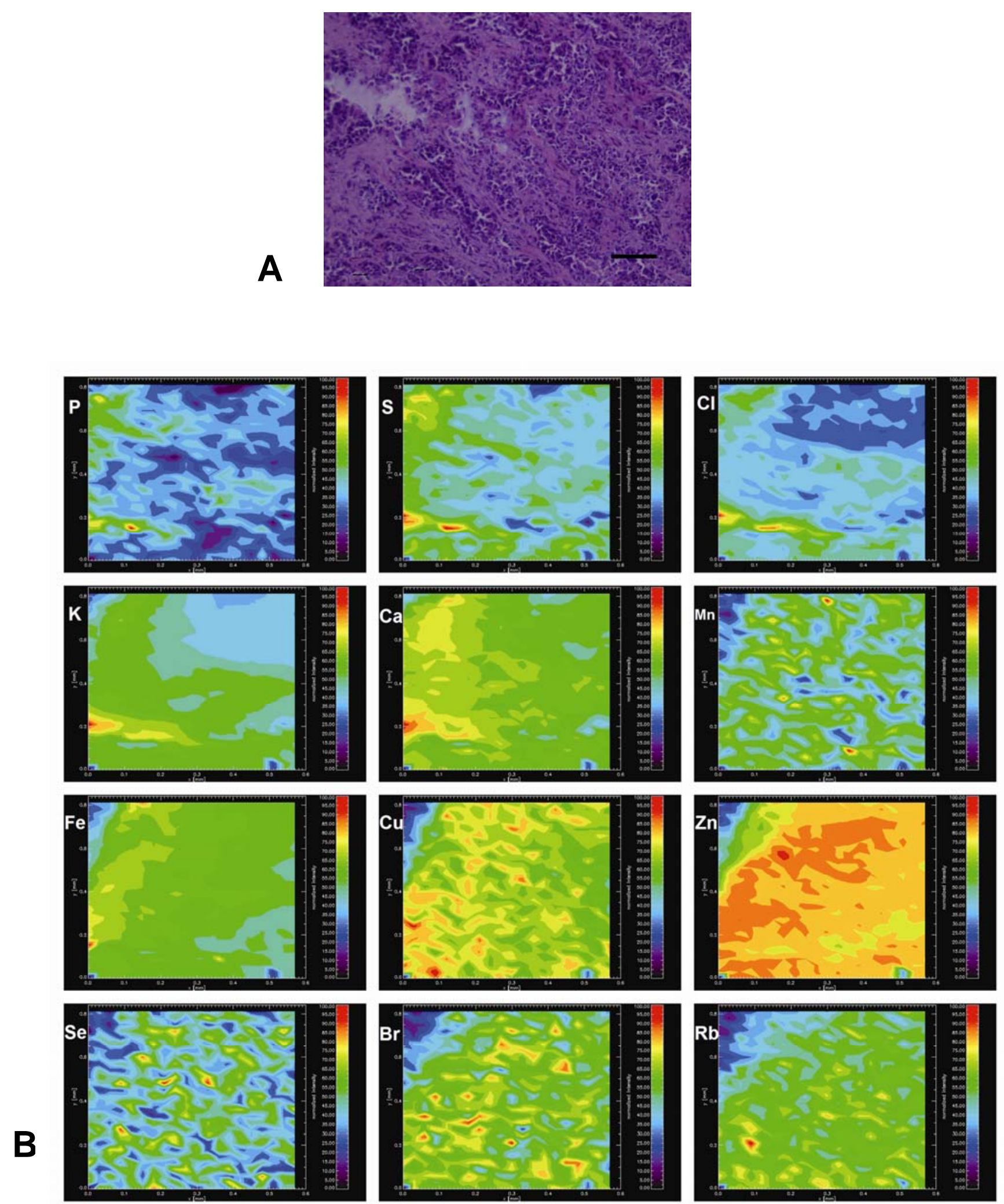

Figura 49 - (A) Fotomicrografia de placentônio bovino GCL 135 dias de gestação, *vermelho (epitélio materno) e *preto (epitélio fetal). (B) Mapeamento bidimensional da concentração elementar em amostra de placentônio por $\mu$ XRF. Barra $500 \mu \mathrm{m}$ 
Placentônio de bovino GCO 225 dias
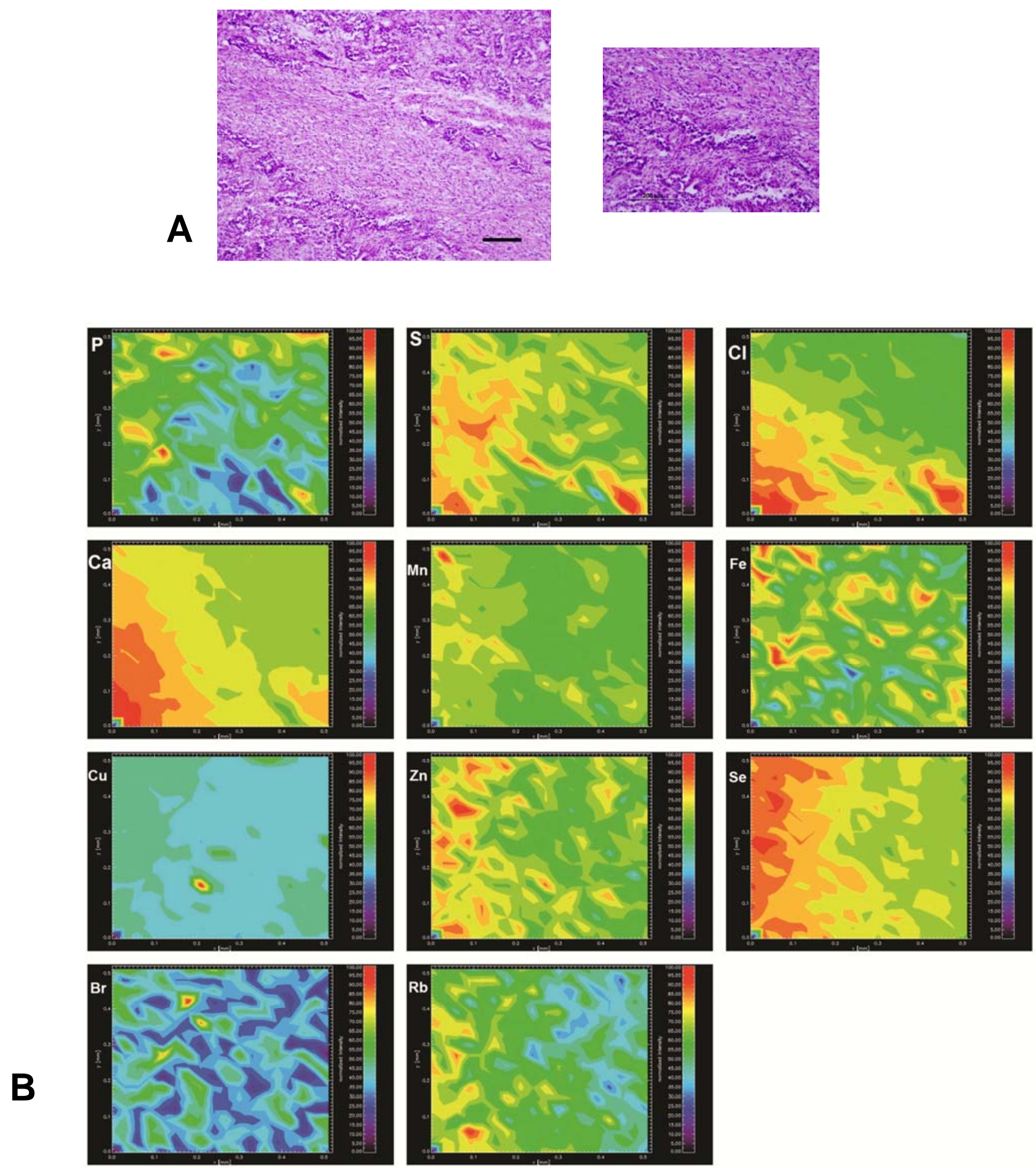

Figura 50 - (A) Fotomicrografia de placentônio bovino GCO com 225 dias de gestação, *vermelho (epitélio materno) e *preto (epitélio fetal). (B) Mapeamento bidimensional da concentração elementar em amostra de placentônio por $\mu$ XRF. Barra: $500 \mu \mathrm{m}, 200 \mu \mathrm{m}$ 
Placentônio de bovino GCL 225 dias
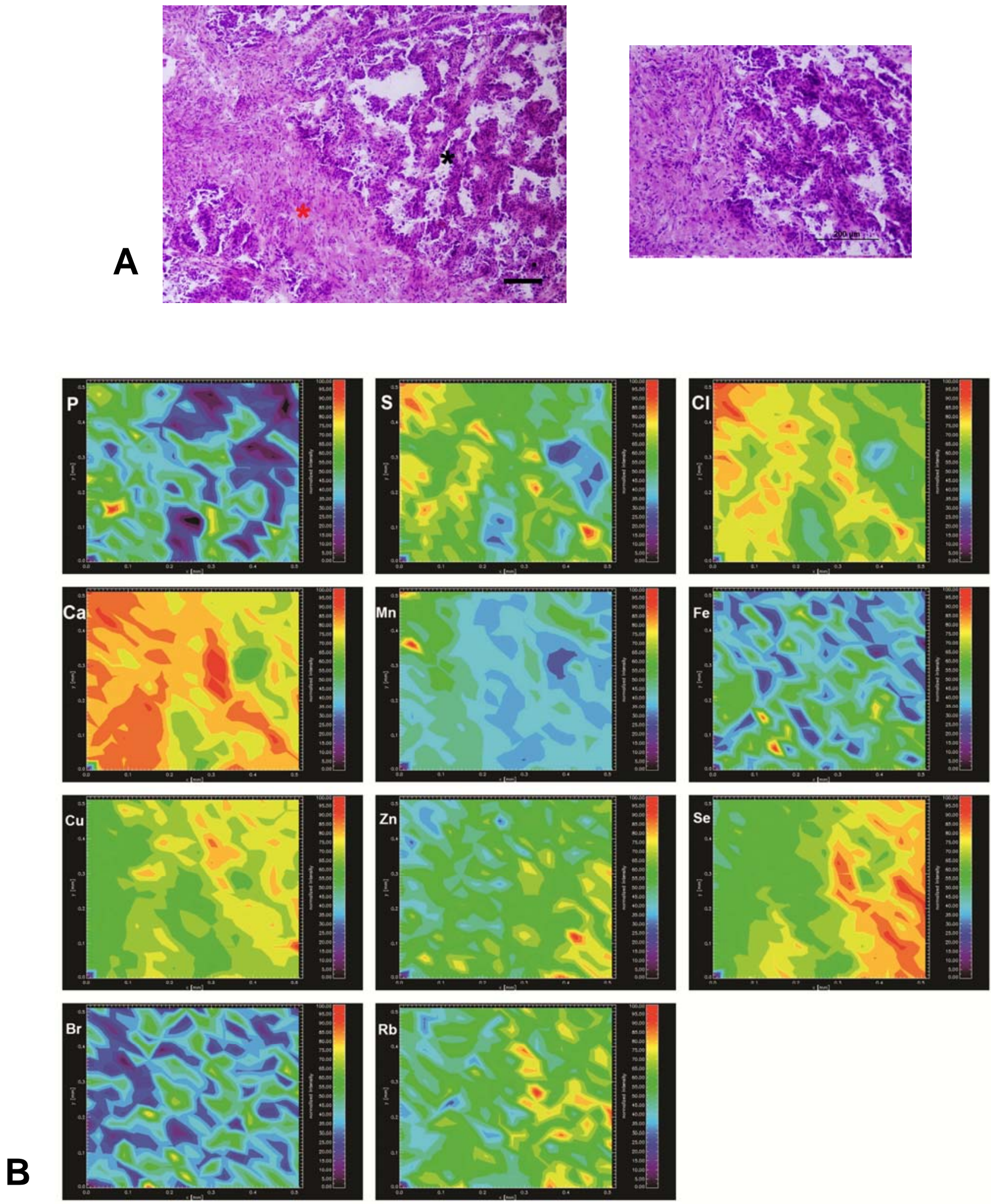

Figura 51 - (A) Fotomicrografia de placentônio bovino GCO com 225 dias de gestação, *vermelho (epitélio materno) e *preto (epitélio fetal). (B) Mapeamento bidimensional da concentração elementar em amostra de placentônio por $\mu \mathrm{XRF}$. Barra: $500 \mu \mathrm{m}, 200 \mu \mathrm{m}$ 
Placentônio de bovino GCO 225 dias
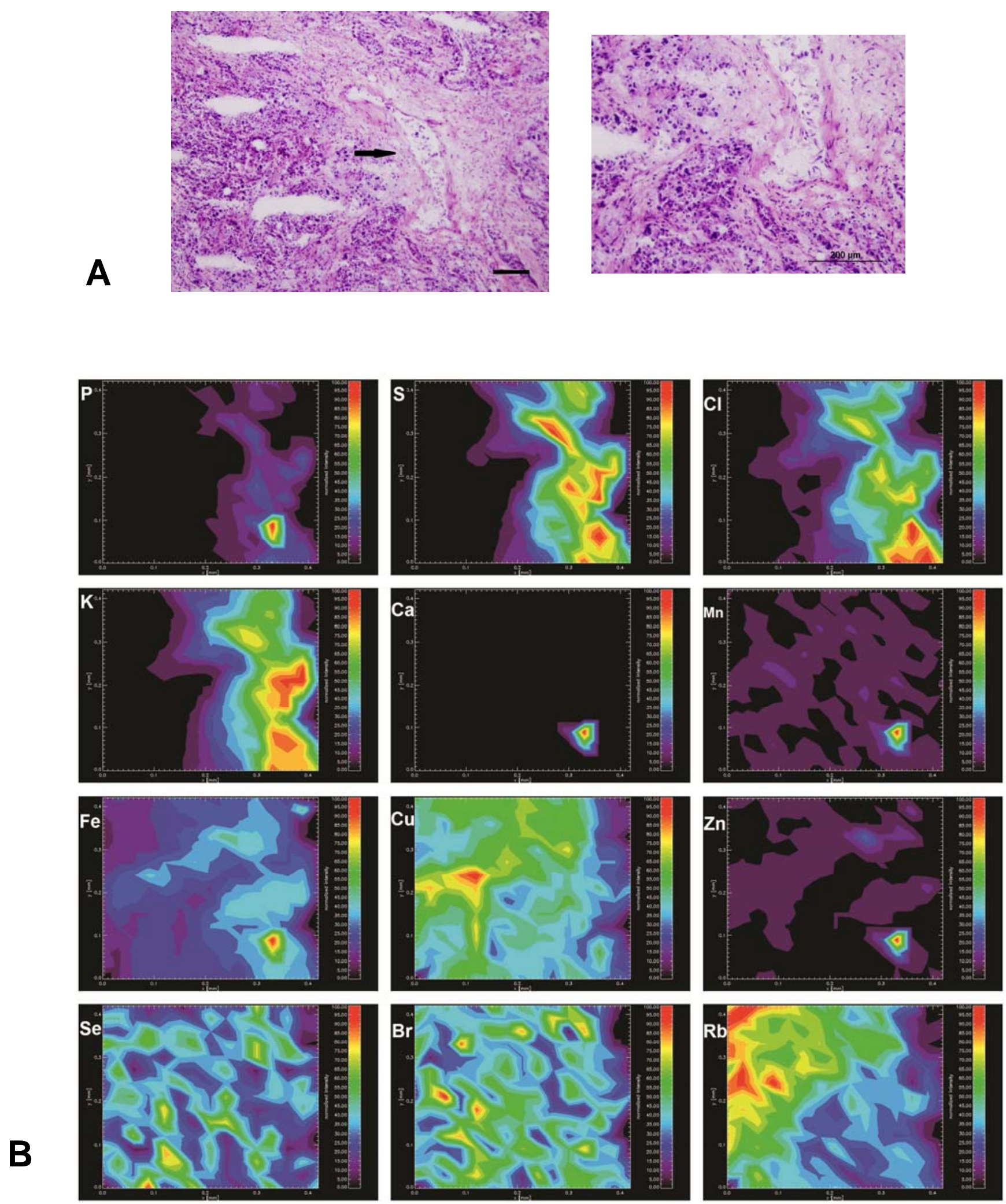

Figura 52 - (A) Fotomicrografia de placentônio bovino GCO com 225 dias de gestação, seta preta (vasos sangüíneos). (B) Mapeamento bidimensional da concentração elementar em amostra de placentônio por $\mu$ XRF. Barra: $500 \mu \mathrm{m}, 200 \mu \mathrm{m}$ 
É bem estabelecido que os elementos traço encontram-se distribuídos heterogeneamente ao longo das amostras, o padrão na sua distribuição pode estar associado a funções biológicas de áreas especificas placentomais. É também de extrema relevância determinar e avaliar os níveis dos elementos traço na placenta, as alterações nos níveis (excesso ou deficiência) vêm sendo correlacionado as desordens na gestação bovina.

Os resultados apresentados nas Figuras 47 a 53 demonstraram que as concentrações dos elementos nas amostras de placenta diferem com relação aos sítios da placenta analisados. Foi investigada também a correlação entre os elementos. Através desses resultados foi possível verificar que existe uma forte correlação entre os elementos P-S-Cl$\mathrm{K}, \mathrm{K}-\mathrm{Ca}-\mathrm{Cl}$, por exemplo. Pela própria função e característica de cada elemento, algumas correlações já eram esperadas, tais como Cl-K, K-Ca, S-Fe.

Os mapas de distribuição elementar qualitativo (Figura 47 a 53) apresentados permitiram-nos observar que com relação aos elementos avaliados nos placentônios dos grupos I, II e III.

a) O elemento fósforo possui o mesmo comportamento em todas as amostras de placentônios de bovinos GCO e GCL analisados, nos três grupos estudados, independente do período gestacional analisado observa-se uma distribuição homogênea no epitélio materno, porém com diferentes intensidades, com pontos de alta intensidades no estroma materno, e intensidade reduzidas ou ausente nas regiões de interdigitação entre as criptas uterinas e vilosidades cotiledonares (interface materno-fetal), picos de intensidades nos trofoblastos, demonstrado nas figuras 47 a 52 , ocorrendo um aumento na intensidade em função da idade gestacional.

b) $\mathrm{O}$ enxofre apresentou o mesmo comportamento que fósforo, não diferindo entre os grupos quando referido ao sitio de concentração, na região do placentônio apresentando maior intensidades no estroma materno, em todos os grupos estudados o perfil modificou-se quando se avaliou-se período gestacional, o período de 90 dias de gestação apresentou baixa ou ausência de elemento na região interface materno-fetal (trofoblasto) representado na figuras 47 e 48 . Nos grupos II e III apresentaram uma distribuição homogênea em toda a superfície com picos de intensidades no estroma materno, apresentando assim um aumento da intensidade do elemento em relação a idade gestacional, para todos os grupos estudados. Este fato pode ser claramente observado nas figuras $47,49,50,51$ e 52, porém, com ausência na região de interface materno-fetal no período gestacional com 225 dias de gestação e alta intensidade nos vasos sangüíneos representado na Figura 53. 
c) O cloro apresentou uma distribuição homogênea sobre toda a superfície das amostras estudadas, com maior intensidade no epitélio materno, porém as amostras do GCL representadas nas figuras 48 e 50 apresentaram uma baixa intensidade na região de interface materno-fetal quando comparada ao GCO, com exceção do período de 225 dias que GCO e GCL apresentaram o mesmo comportamento no padrão de distribuição e representando nas figuras 51 e 52 . No período gestacional de 225 dias o cloro apresentou o mesmo comportamento que P, S e K, isto é, ausência na região de interface materno-fetal e altas intensidade nos vasos sanguíneos do estroma materno (Figura 53).

d) O potássio apresentou o mesmo comportamento que o $\mathrm{S}$ e $\mathrm{Cl}$ com distribuição homogênea por toda a superfície com maior intensidade no estroma materno, porém apresentou intensidade reduzida na amostra GCL do grupo II representados na figura 50. Na amostras de 225 dias de gestação apresentou ausência na região interface materno-fetal e maior intensidade no vaso sanguíneo do estroma materno da figura 53.

e) O cálcio está presente em todas as regiões analisadas, sendo sua distribuição homogênea, se revelando com maior intensidade na região de interface materno fetal principalmente nos trofoblasto independente do período gestacional estudado, com exceção do período gestacional de 225 dias que apresentou ausência do elemento na face materno-fetal, com apenas um ponto de intensidade dentro do vaso sanguíneo do estroma materno, apresentando o mesmo comportamento que o Zn e Mn, representados na figura 53.

f) O manganês apresentou distribuição homogênea sobre toda a superfície da amostra com poucos pontos de alta intensidade localizados nas regiões de interface materna fetal, as amostras de clone apresentaram menor intensidade que as amostras GCO apresentadas nas figuras 48 e 50. Com exceção do período gestacional de 225 dias que apresentou ausência do elemento, com apenas um ponto de concentração dentro do vaso sanguíneo do estroma materno, comportamento semelhante aos elementos $\mathrm{Zn}$ e $\mathrm{Ca}$, representados na figura 53, mas com traço de intensidade no epitélio materno fetal.

g) $\mathrm{O}$ ferro apresentou distribuição homogênea com maior concentração na região de interface materno fetal, as amostras de placentônio GCL apresentaram menor intensidades que as amostras GCO demonstradas nas figuras 48, 50 e 52 apresentando aumento na intensidades com relação ao período gestacional mostrados 
nas figura 50 e 51 . Na amostra de 225 dias de gestação a maior intensidade de ferro foi visualizado no vaso sanguíneo com fragmentos de intensidades na região de trofoblasto, na figura 53.

h) $\mathrm{O}$ cobre apresentou distribuição sobre todo o tecido analisado, mas com intensidades mais elevada nas regiões de interdigitação entre as criptas uterinas e vilosidades cotiledonares, picos de intensidade nas vilosidades com trofoblastos, demonstrado nas figuras 47, 49 e 51 a amostra de GCL com período gestacional de 90 dias apresentou menor intensidade quando comparada com a amostra GCO indicada na figura 48. O inverso ocorreu na amostra de 225 dias de gestação no qual CGO apresentou menor intensidade que o GCL, mas ambas as amostras apresentaram o mesmo padrão de distribuição, homogênea sobre a superfície estudada, conforme observa-se nas figuras 51 e 52. Na amostra com 225 dias de gestação o comportamento o elemento cobre foi diferente dos outros elementos apresentou-se mais intenso fora do vaso sanguíneo, mas com intensidade reduzida dentro do vaso sanguíneo, conforme a figura 53.

i) O zinco apresentou distribuição homogênea sobre todo o tecido analisado, mas com intensidade mais elevada nas regiões de interdigitação entre as criptas uterinas e vilosidades cotiledonares, picos de concentração nas vilosidades com trofoblastos, podem ser visualizados figuras 47, 49 e 51. A amostra GCL com período gestacional de 90 e 225 dias apresentaram-se com intensidade reduzida quando comparada com a amostra GCO de acordo com as figura 48 e 52. Na amostra com 225 dias de gestação comportamento similar que o apresentado pelo Ca e Mn foi observado com reduzida intensidade ou ausência do elemento, apresentando apenas um ponto de intensidade, conforme detalhes na figura 53.

j) O selênio apresentou distribuição homogênea sobre o tecido analisado, com maior intensidade para a interface materno-fetal. Observou-se aumento na intensidade no tecido progressivamente com os períodos gestacionais conforme visualizado nas figuras 47, 50, 51 e 53. A concentração não diferiu em relação a GCL e GCO, com exceção para amostra de placentônio de bovino GCL com 90 dias de gestação, que apresentou maior intensidade no tecido quando comparado com o GCO. Na amostra com 225 dias de gestação a distribuição foi homogênea, mas com baixa intensidade com os outros períodos gestacionais, mas com picos de intensidade fora do vaso sanguíneo (Figura 53). 
k) O elemento bromo apresentou distribuição homogênea com maior concentração na região de interface materno fetal, não diferindo entre GCL e GCO, apresentando um aumento da intensidade no grupo II demonstrados na figura $50 \mathrm{e}$ 51, apresentando uma diminuição na intensidade no grupo III, tanto no GCL quanto GCO. Na amostra com 225 dias de gestação a distribuição foi homogênea, mas com maior intensidade na interface materno-fetal (Figura 53).

I) $\mathrm{O}$ elemento rubídio apresentou distribuição homogênea com maior i intensidade na região de interface materno fetal, não diferindo entre GCL e GCO e período gestacional mostrado na figura 47 a 52. Na amostra com 225 dias de gestação a distribuição foi homogênea com maior intensidade na interface materno fetal, mas com baixa intensidade no vaso sanguíneo (Figura 53).

Nossos resultados confirmam que a maior concentração elementar ocorre na região de interdigitação entre as criptas carunculares do epitélio uterino e as vilosidades cotiledonária com células trofoblásticas, confirmando que nesta região ocorre a troca de nutrientes. Esta região é constituída por numerosos vilos coriônicos, estas ramificações aumentam com o avanço da prenhez, estes vilos são intensamente ramificados, que se entremeiam nas criptas das carúnculas maternas. Cada vilo é formado por um eixo de mesênquima vascularizado, recoberto por células trofoblástica (CAZERTA, 2007).

As estruturas anatômicas que regulam ativamente as taxas de transferência em cada direção para cada tipo de molécula, situadas entre os dois compartimentos materno e fetal (sinciotrofloblasto e endotélio fetal) concentram-se nas vilosidades secundárias e terciárias, que são sítios de crítica regulação de transferência de materiais. A interface fetal é constituída por uma fina camada de sinciotrofloblasto. Entre o sinciotrofloblasto e os capilares das células endoteliais reside uma fina camada de matriz extracelular (ATKINSON; BOYD; SIBLEY, 2006).

No trabalho de Cazerta et al. (2007) os hematomas placentários foram observados entre o epitélio uterino e trofoblásticos, a partir dos 3 meses de prenhez. A presença de eritrócitos nas células trofoblásticas elucidou a eritrofagocitose. A reação histoquímica de Perl's permitiu provas da existência de ferro férrico no trofoblasto.

A passagem e a troca de nutrientes da mãe para o feto são realizadas por meio dos vilos placentários (MAYHEW, 2002). Justamente nessas áreas dos vilos, nas regiões das trocas materno fetais, tem-se observado uma diferença estrutural e morfológica significativa na placenta de animais GCL comparados aos animais GCO. 
Segundo Enomoto e Hiruma (2001) a taxa de absorção de Zn na placenta e semelhante a do feto, o que indica que a mesma concentração de $\mathrm{Zn}$ pode ser encontrada no feto. A taxa de absorção de Fe no feto é mais elevada do que na placenta e no sangue materno. A procura de Fe pelo feto aumenta durante o último período de gravidez. O Zn está envolvido na formação da prostaglandinas porque as enzimas $\mathrm{Zn}$ controlam a cascata ácido araquidônico. As prostaglandina são necessárias para a manutenção da gravidez porque PGF2a é secretada no lúmen uterino. Assim o Zn pode melhorar o desenvolvimento do feto através de seus efeitos sobre a PGF2a. A prostaglandina F2a é também importante ao parto para iniciar as contrações uterinas exigida para expulsão de feto. No trabalho de Hostetler et al. (2000) os níveis de Zn no feto foi 1 a 8 vezes maiores do que do endométrio, o que é indicativo de maior absorção ou utilização pelo feto.

No trabalho de Enomoto e Hiruma (2001) a concentração de Mn na placenta é mais alta do que o $\mathrm{Zn}$, a taxa de absorção de Mn no feto é muito elevada. Os elementos $\mathrm{Na}$, $\mathrm{Cu}, \mathrm{Rb}$ são transportados para a placenta a partir do sangue materno e se acumulam na placenta, feto e fluido amniótico. Elementos $\mathrm{Mn}, \mathrm{Fe}, \mathrm{Zn}$ e Se principalmente se acumulam no feto. As taxas destes elementos foram correlacionadas com o crescimento fetal.

O Fe é transportado pela membrana apical através de um transportador de metal divalente 1 (DMT-1), que além deste mineral também transporta outros prótons como $\mathrm{Cu}, \mathrm{Zn}$ e Mn (DUNN; HAHMANTO; RICHARDSON, 2006), sendo esta uma das causas entre o antagonismo pela mobiliferrina, proteína responsável pelo transporte intracelular de $\mathrm{Fe}, \mathrm{Zn}$, Co e $\mathrm{Pb}$, causando competição pela absorção entre eles (CHASTON et al.,2008)

Em nosso trabalho o $\mathrm{Cu}$ apresentou distribuição homogênea sobre todos os tecidos materno e fetal, com maior concentração no interface materno-fetal. No trabalho de HOSTETLER et al. (2000), as concentrações de $\mathrm{Cu}$ foram substancialmente maiores nos tecido do feto do que no endométrio de suínos. Este resultado podem indicar um aumento da procura de $\mathrm{Cu}$ pelo feto de tal forma que este désvio do sistema $\mathrm{Cu}$ materno para o desenvolvimento do embrião e do feto. Funções de cobre como ativador de sistemas enzimáticos associados com o metabolismo de Fe é necessário para hematopoiese. O Fe é transportado para o feto pela uteroferrina, uma proteína secretada pelo endométrio durante a gravidez, o Cu pode desempenhar um papel na ativação da secreção da uteroferrina.

No trabalho de Hostetler et al. (2000) os níveis de Mn em embriões e fetos de suínos foram 2 a 12 vezes maiores do que no endométrio durante os primeiros meses de gestação. O Mn pode desempenhar um papel de secreção de progesterona. No trabalho de 
Hidiroglou (1979), as concentrações de $\mathrm{Mn}$ e $\mathrm{Cl}$ de ovelhas aumentou entre 4 e 11 dias e a sub-concentração ideal de progesterona tem sido implicada com causa de perda embrionária.

Burk et al. (1983) relataram uma acumulação preferencial de Se em tecido materno da placenta. O Se tem um papel importante na manutenção da integridade da célula e das organelas dentro das células e podem atuar por meio desse mecanismo para proteger o feto de mortalidade devido aos danos oxidadativos, que ocorrem na gestação. 
Região interplacentomal de bovino 90 dias

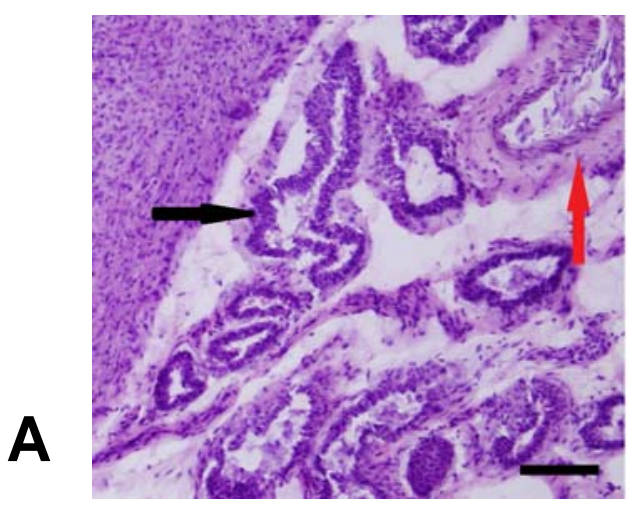

B
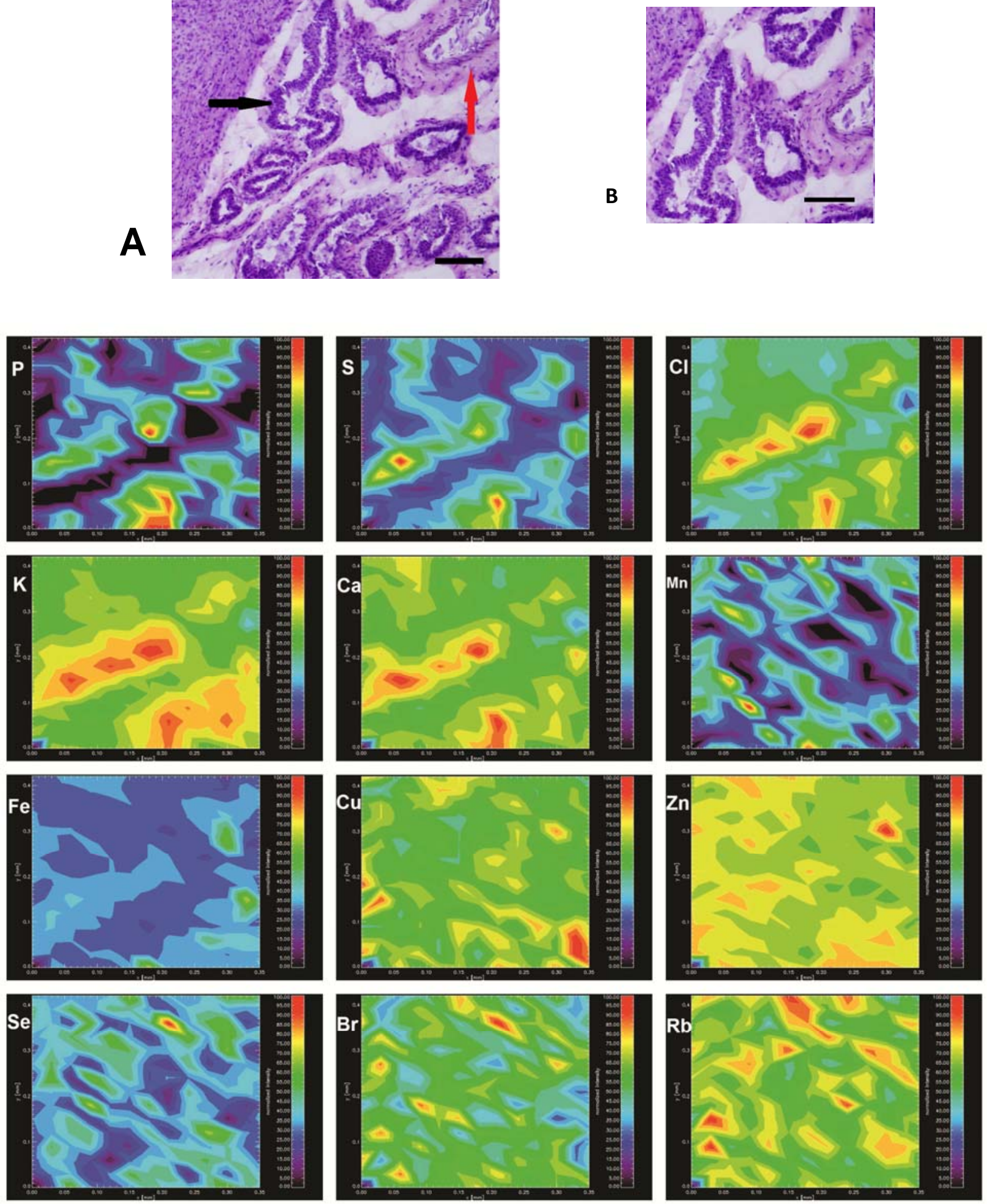

Figura 53 - (A e B) Fotomicrografia da região interplacentomal de bovino GCL 90 dias de gestação, C seta preta (glândulas endometriais) e seta vermelha (vaso sanguíneo). (C) Mapeamento C bidimensional da concentração em amostra de placentônio. Barra (A) $500 \mu \mathrm{m}$, (B) $200 \mu \mathrm{m}$ 
Região Interplacentomal bovino 135 dias
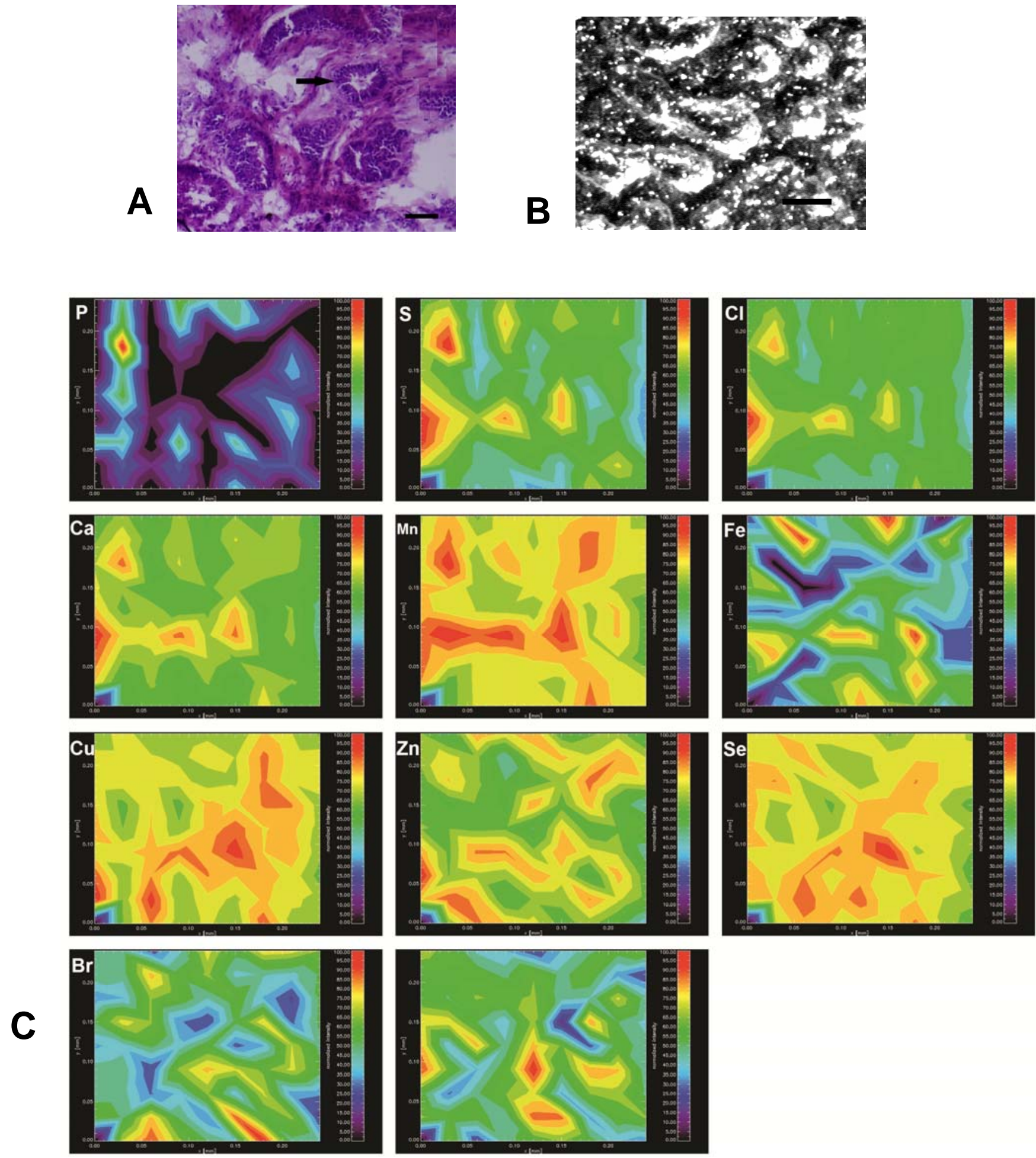

Figura 54- (A) Fotomicrografia da região interplacentomal de bovino GCL 135 dias de gestação e seta preta (glândulas endometriais). (B) Imagem adquirida de amostra de placentônio liofilizada no momento da aquisição dos dados de $\mu \mathrm{XRF}$. (C) Mapeamento bidimensional da concentração elementares .Barra (A) $500 \mu \mathrm{m}$, (B) $0,5 \mathrm{~mm}$ 
Região Interplacentomal bovino 225dias
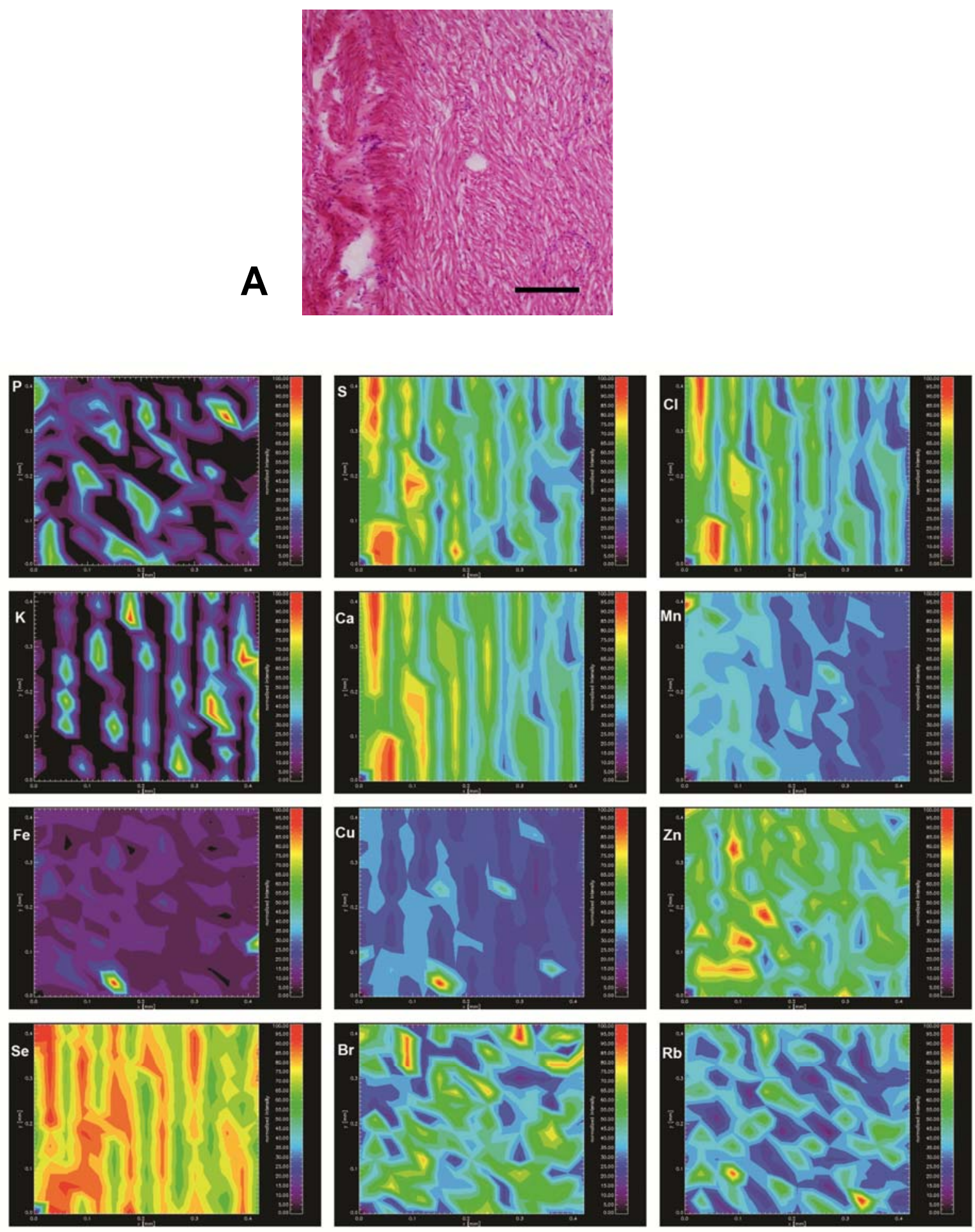

B

Figura 55- (A) Fotomicrografia da região interplacentomal de bovino GCL 225 dias de gestação, seta fibras musculares do miométrio do epitélio uterino. (B) Mapeamento bidimensional da concentração elementar em amostra de placentônio por $\mu$ XRF. Barra: $500 \mu \mathrm{m}$ 
Os mapas de distribuição das figuras 54 a 56 permitiu-nos concluir que observações nas intensidades dos elementos na região interplacentomal dos grupos I, II e III de bovinos GCO e GCL:

a) $\mathrm{O}$ fósforo nesta região representado nas figuras 54 e 55 apresentaram uma intensidade reduzida no estroma endometrial e intensidade maior nas glândulas endometriais. Na figura 56 apresentou menor intensidade nas fibras musculares do miométrio, só em alguns grupos de células apresentaram intensidade mais elevada deste elemento.

b) $\mathrm{O}$ enxofre apresentou o mesmo comportamento nos placentônios com aumento da intensidade em relação a idade gestacional. Na figura 54 do grupo I o estroma endometrial apresentou baixa intensidade, com alta intensidade nas glândulas endometriais. Com avançar da idade gestacional o estroma endometrial apresentou uma distribuição homogênea da intensidade com alta da intensidade nas glândulas endometriais demonstrado na figura 55 e 56 .

c) O cloro apresentou uma distribuição homogênea em todas a superfície analisadas com alta intensidade nas glândulas endometriais este comportamento se manteve em todos os períodos gestacionais analisados os quais podem ser visualizados nas figuras 54,55 e 56 .

d) O potássio apresentou o mesmo comportamento que $\mathrm{Ca}$ e $\mathrm{Cl}$, com distribuição homogênea por toda a superfície com maior intensidade nas glândulas endometriais representados na figura 54 e 55, porém o miométrio apresentou menor intensidade observou-se a distribuição nas fibras musculares representados na figura 56.

e) O cálcio apresentou uma distribuição homogênea em todas a superfície analisada com alta intensidade nas glândulas endometriais este comportamento se manteve em todos os períodos gestacionais analisados demonstrados nas figuras 54, 55 . $\mathrm{Na}$ figura 56 o cálcio apresenta maior intensidade nas fibras musculares do miométrio.

f) O manganês apresenta maior intensidade nas glândulas endometriais, com aumento da intensidade em relação ao período gestacional, conforme demonstrado nas figuras 54 e 55 a intensidade foi reduzida no miométrio conforme a figura 56, com maior intensidade na glândula endometrial.

g) O ferro apresentou maior intensidade nas glândulas endometriais, observado na figura 54, apresentou um aumento na intensidade com relação ao período 
gestacional conforme figura 55. Na figura 56 apresentou concentração nas fibras musculares do miométrio.

h) Distribuição de cobre foi homogênea sobre todo o estroma endometrial, com pontos elevados de intensidade nas glândulas endometriais, observado no grupo I pela figura 54, O grupo II apresentou um aumento da intensidade nas glândulas endometriais em relação a idade gestacional, observado na figura 55. Baixa intensidade no miométrio dos animais do grupo III, mas comportamento de distribuição acompanhando as fibras musculares, observados na figura 56.

i) $\mathrm{O}$ zinco apresentou uma distribuição homogênea sobre todo o estroma endometrial, com pontos elevados de concentração nas glândulas endometriais, apresentando aumento da intensidade nas glândulas endometriais em relação a idade gestacional, observado na figura 54 e 55, Na figura 56, observa-se elevadas intensidade de zinco nas fibras musculares do miométrio, com picos na glândula endometrial.

j) O selênio apresentou o comportamento semelhante com distribuição homogênea sobre o estroma endometrial com maior intensidade nas glândulas endometriais, apresentando um aumento na concentração com relação a idade gestacional, conforme as figuras 54 e 55, apresentando o mesmo comportamento nas fibras do miométrio, com intensidade superiores na intensidade nas fibras musculares, demonstrado na figura 56.

k) O elemento bromo apresentou uma distribuição homogênea sobre o estroma endometrial com maior intensidade nas glândulas endometriais, a concentração aumentou no estroma endometrial e glândulas endometriais com relação a idade gestacional, observados na figura 54 e 55, apresentando uma intensidade moderada nas fibras musculares do miométrio, com alguns pontos de maior concentração nas fibras musculares,demonstrada na figura 56.

1) $\mathrm{Na}$ região interplacentomal distribuição de rubídio foi homogênea sobre $\mathrm{o}$ estroma endometrial com maior intensidade nas glândulas endometriais, a intensidade aumentou no estroma endometrial e glândulas endometriais com relação a idade gestacional, conforme apresentado nas figuras 54 e 55, apresentando baixa intensidade nas fibras musculares do miométrio, demonstrada na figura 56. 
A região interplacentomal libera um líquido albuminoso, denominado leite uterino que é rico em proteína. Essa secreção é absorvida pelo trofoblasto fetal constitui-se em importante fonte de nutrição para o feto (MOSSMAN, 1987; GRAY ET AL., 2001).

As glândulas endometriais são importante veículo para troca de nutrientes entre a mãe e o feto. Esta fonte de nutriente é histiotróficas, cuja nutrição ocorre a partir de secreção das glândulas uterinas ricas em enzimas, citosinas, fatores de crescimento, íons, tais como ferro, glicose, proteínas de transporte e moléculas de adesão (HOYES, 1972; AITKEN, et al., 1973; GRAY et al., 2001 a,b).

Em nossos resultados foram observados que todos os elementos estudados apresentaram a maior distribuição elementar nas glândulas endometriais. Os resultados foram confirmados por outros trabalhos Pereira (2004) e Marques et al. (2007) as reações fosfatase ácida nas glândulas endometriais de búfalas e vacas são positivas, isto significa que também realizam fagocitose além do placentônio. Este fato também foi observado por Wislock e Dempsey (1946) na placenta de gatas. No trabalho de Marques et al. (2007) as glândulas endometriais reagiram positivamente a reação de Perl's que marca o ferro férrico. 


\subsection{MAPAS DE DISTRIBUIÇÃO DE INTERELAÇÃO ELEMENTAR, $\mu$ XRF}

Nos mapas de distribuição e interelação dos elementos, as áreas que apresentam mudanças nas cores padrão dos elementos, citadas acima das figuras respectivas, indicam uma relação de forma moderada, acentuada ou nula entre os elementos, as regiões que apresentam maior intensidade das cores representam regiões com maior intensidade dos elementos. Os mapas de distribuição das intensidades de $\mathrm{K}, \mathrm{Ca}, \mathrm{Fe}, \mathrm{Cu}, \mathrm{Zn}, \mathrm{Br}$ e $\mathrm{Rb}$ estão representados nas figuras 58 a 67 respectivamente. Nestes mapas, as cores indicam o gradiente de intensidade dos elementos, sendo que para cada idade foi representa por uma única amostra.

O mapeamento foi realizado em microplacentônios e região interplacentomal de bovino (Figura 57). O programa utilizado para gerar estes mapas foi PyMca 4.40 - Win32 ESRF.
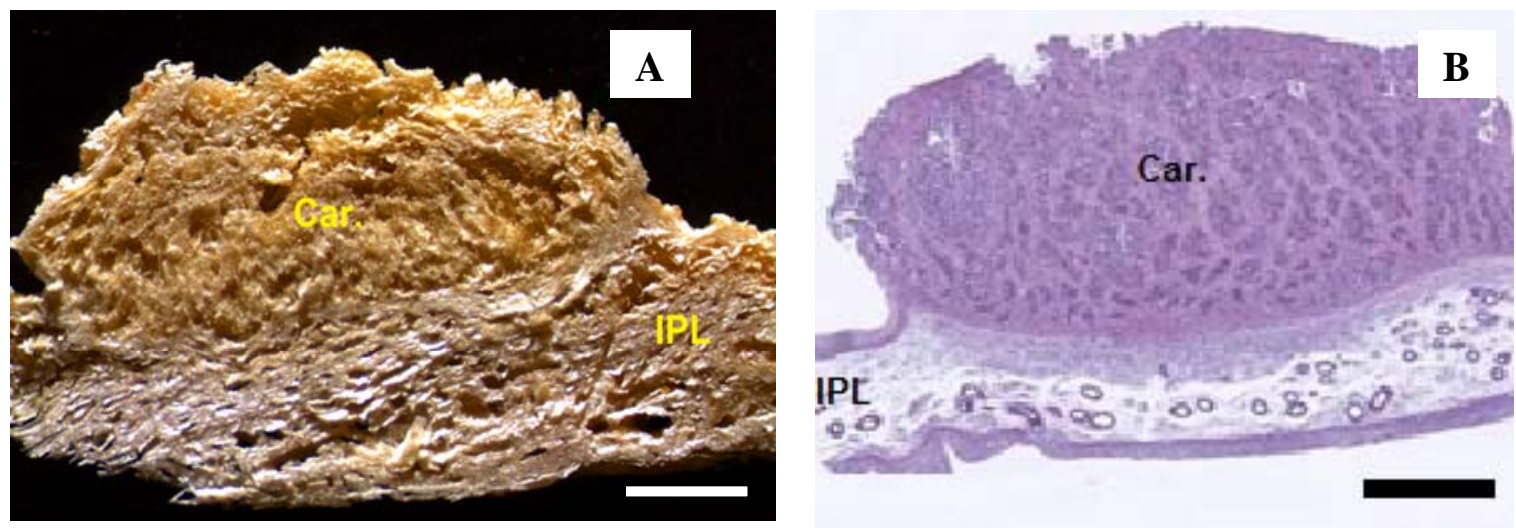

Figura 56 - (A) microplacentônio liofilizado, (B) histologia de microplacentônio. Barra: (A) $1,5 \mathrm{~cm},(\mathrm{~B}) 200 \mu \mathrm{m}$ 

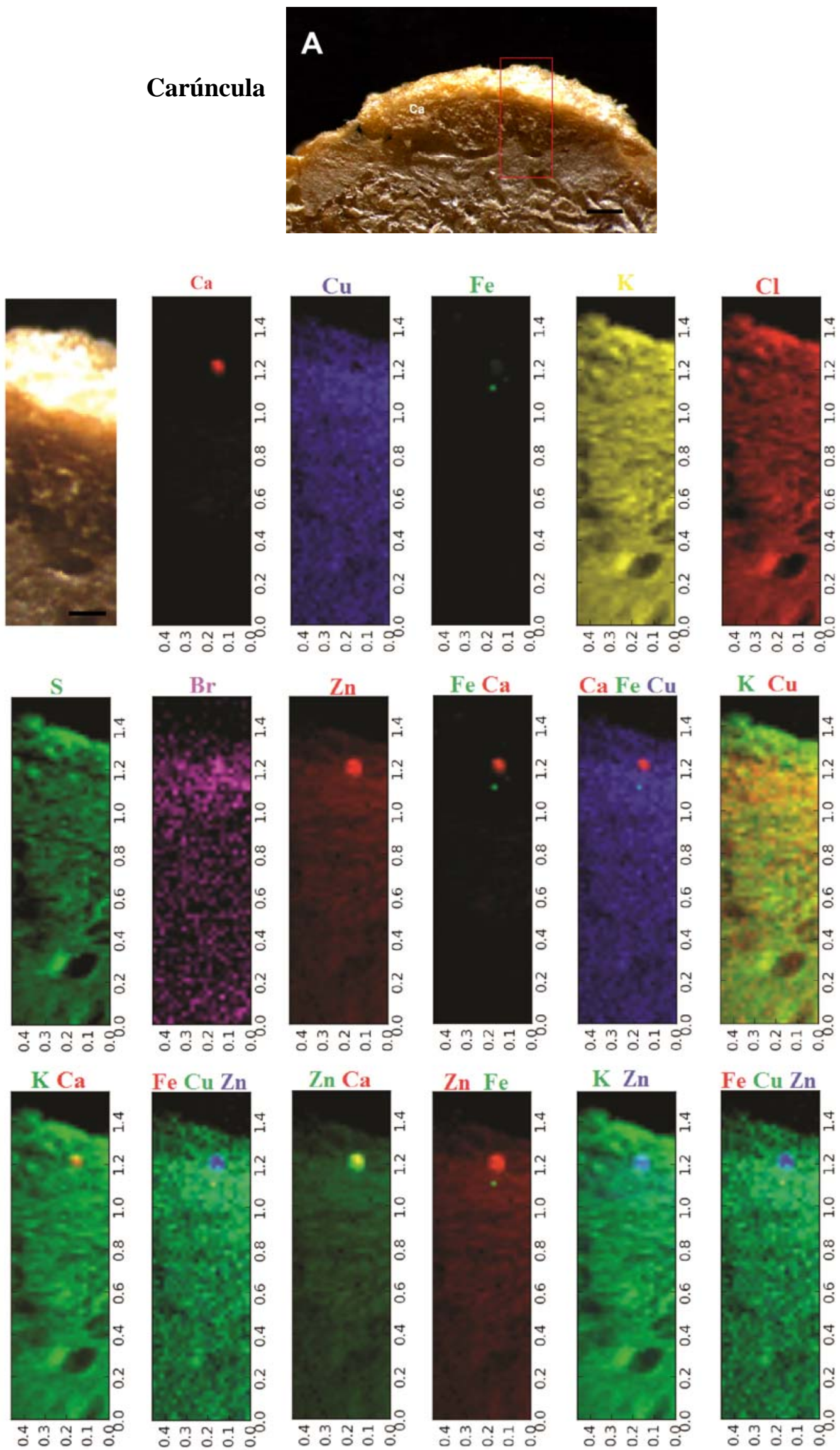

Figura 57 - (A) Imagem de microplacentônio região caruncular de placenta bovina. (B) Mapeamento bidimensional da distribuição elementar (escala em milímetros) em amostra de placentônio $\mu \mathrm{XRF}$. Barra: $1 \mathrm{~cm}$ 


\section{Região Central da Carúncula}
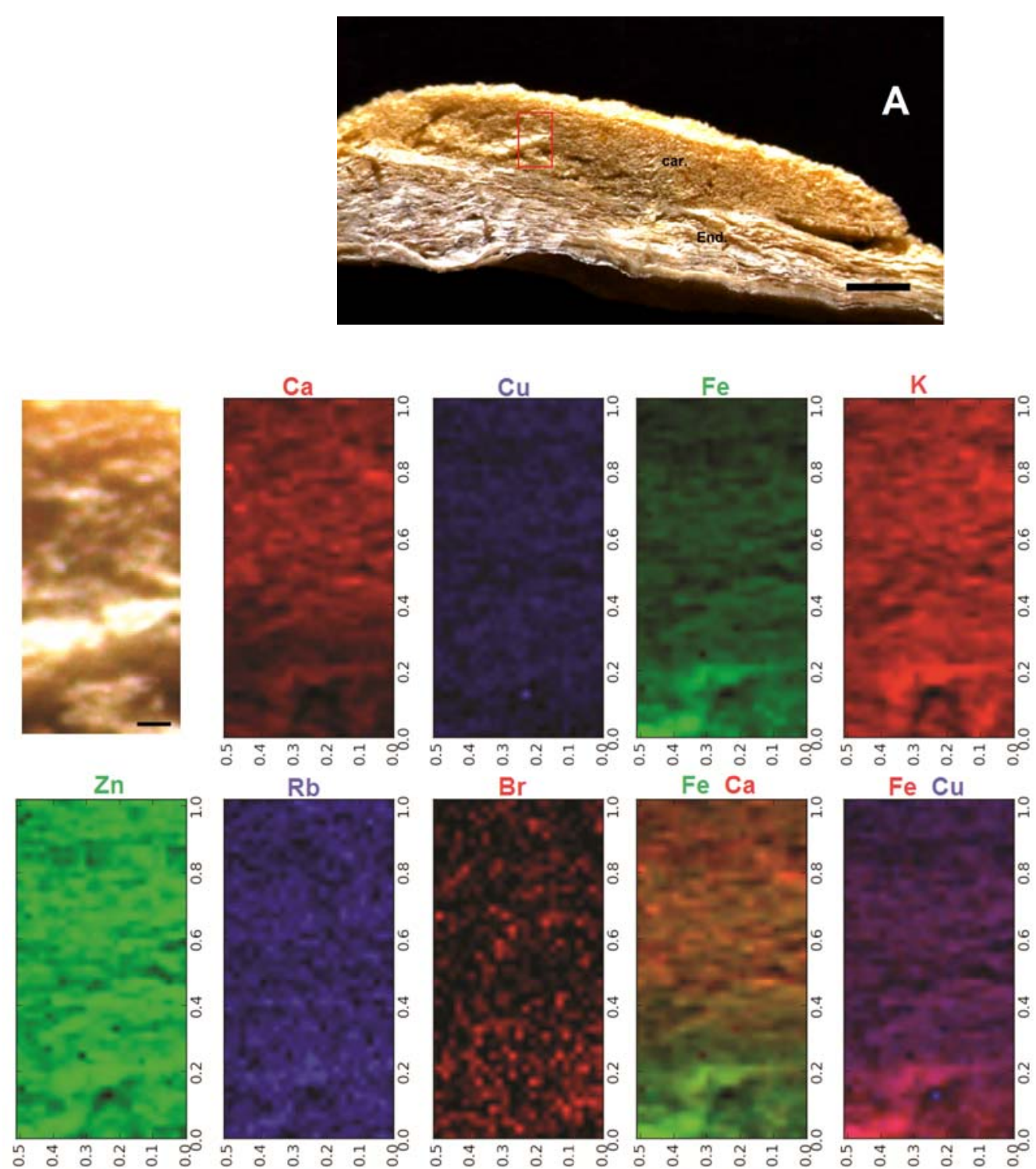

$\mathrm{Br}$

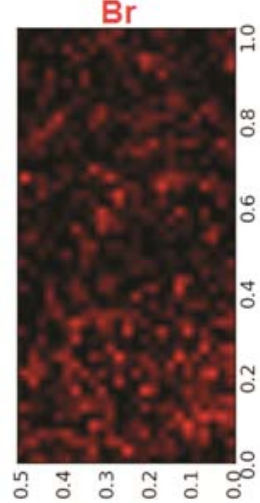

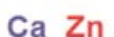
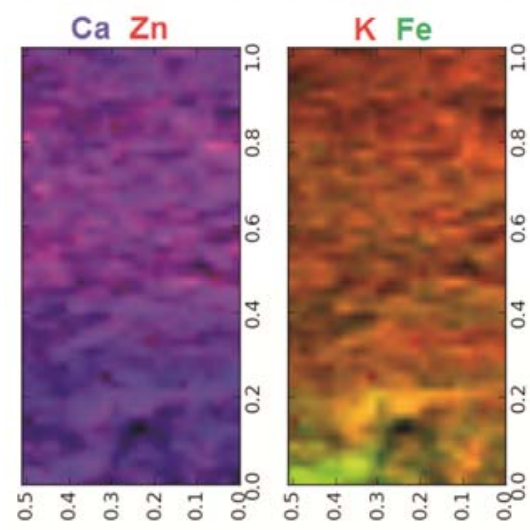

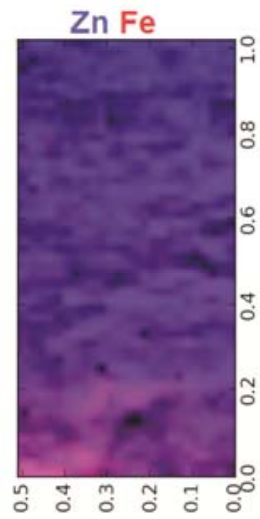

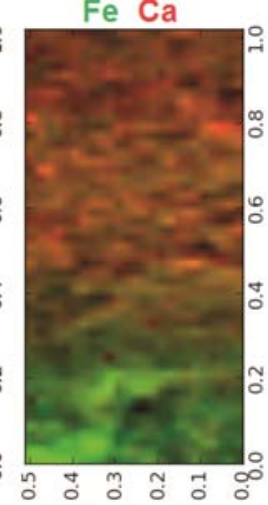

$\mathrm{Fe} \mathrm{Cu}$

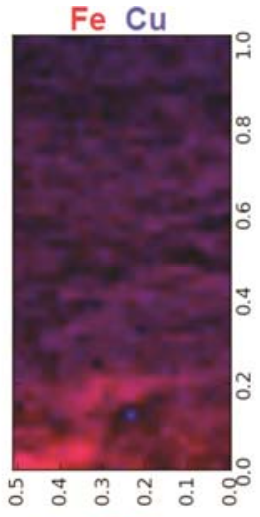

$\mathrm{Fe} \mathrm{Ca} \mathrm{K}$

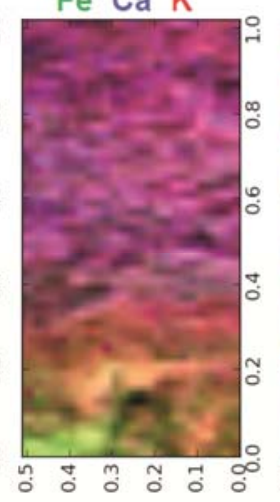

$\mathrm{Ca} \mathrm{K} \mathrm{Cu}$

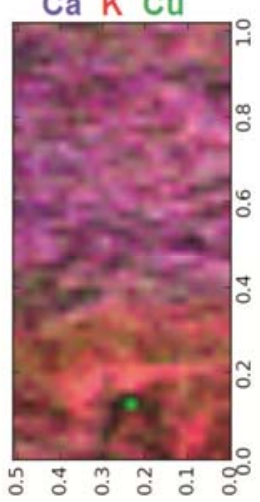

Figure 58 - Imagem da região central da carúncula de placenta bovina que foi mapeada sinalizada em vermelho. Mapeamento bidimensional da distribuição elementar (escala em milímetros) em amostra de placentônio por $\mu$ XRF. Barra: (A) 1,5 cm (B) $0,1 \mathrm{~mm}$ 


\section{Região Marginal do Placentônio}
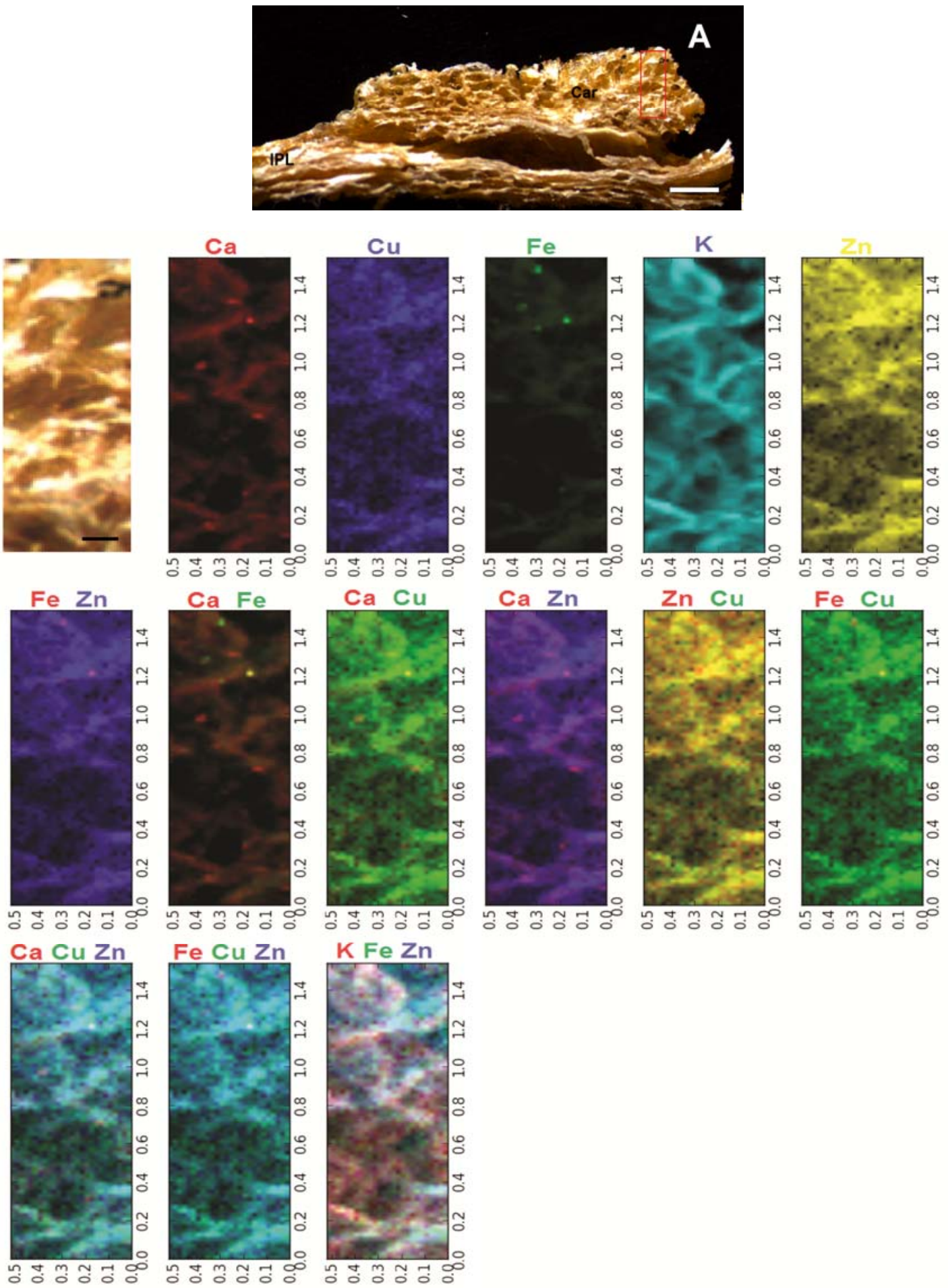

Figure 59 - Imagem da região marginal da carúncula de placenta bovina que foi mapeada sinalizada em vermelho. Mapeamento bidimensional da distribuição elementar (escala em milímetros) em amostra de placentônio por $\mu$ XRF. Barra: (A) $1,5 \mathrm{~cm}$, (B) $0,1 \mathrm{~mm}$ 


\section{Cotilédone}
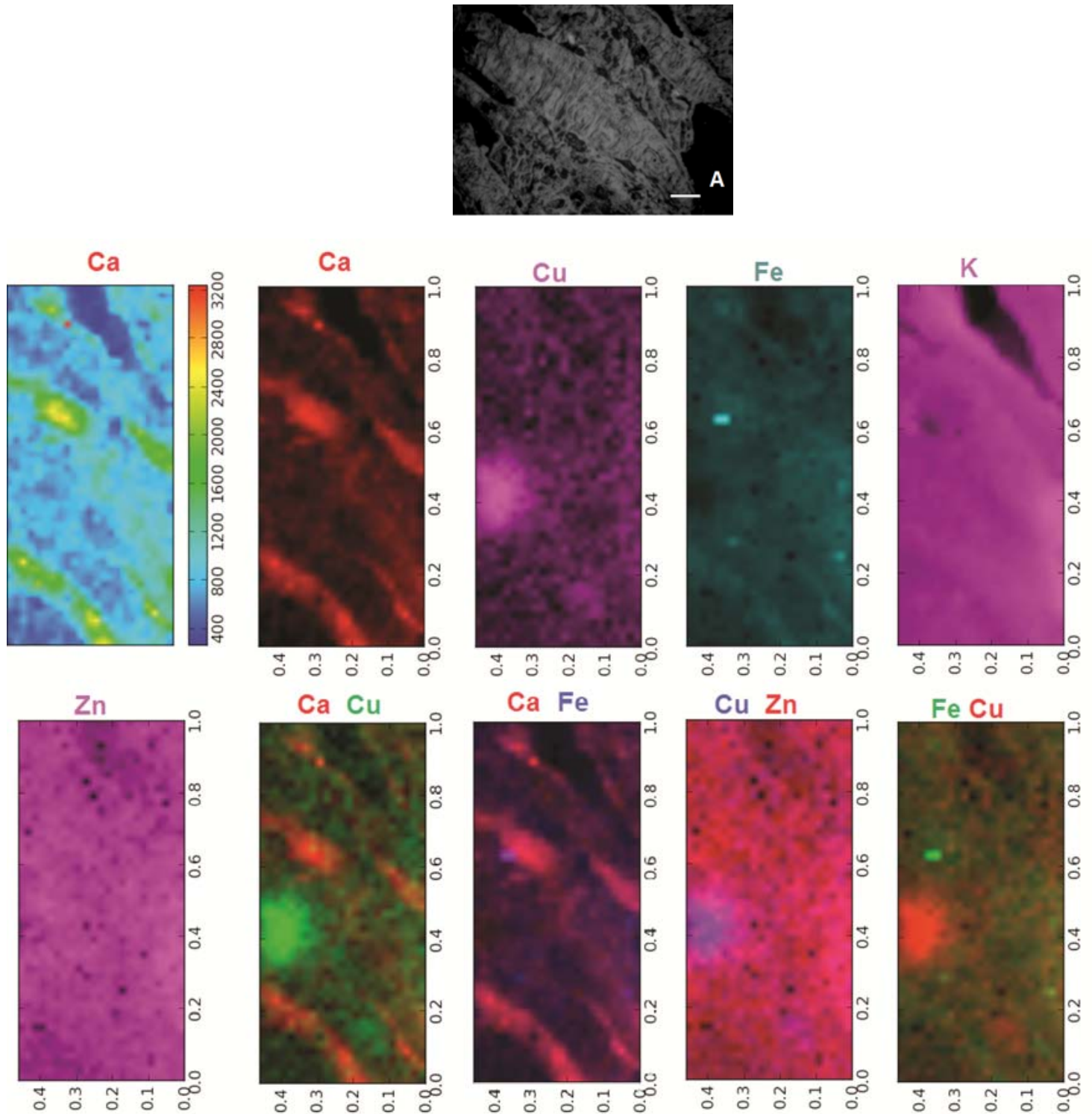

$\mathrm{Ca} \mathrm{Fe}$
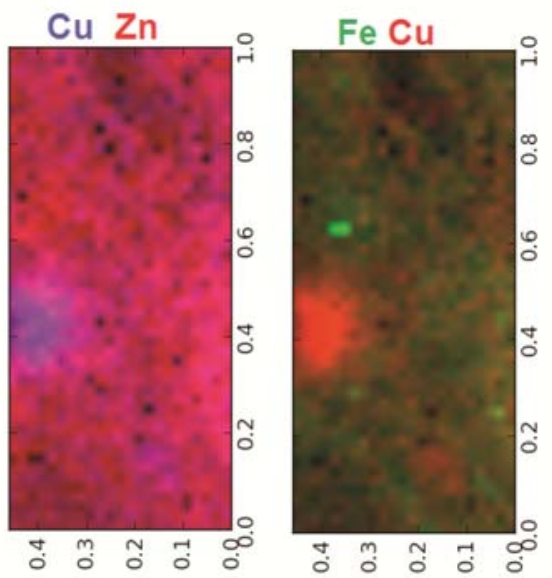

$\mathrm{Fe} \mathrm{K}$

$\mathrm{Fe} \mathrm{Cu}$

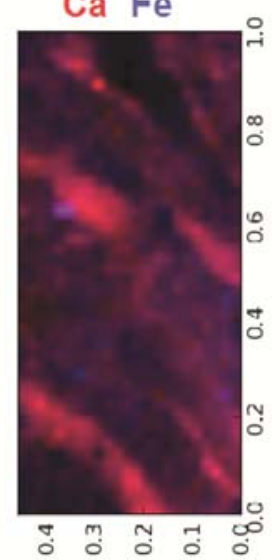

$\mathrm{K}<\mathrm{n}$
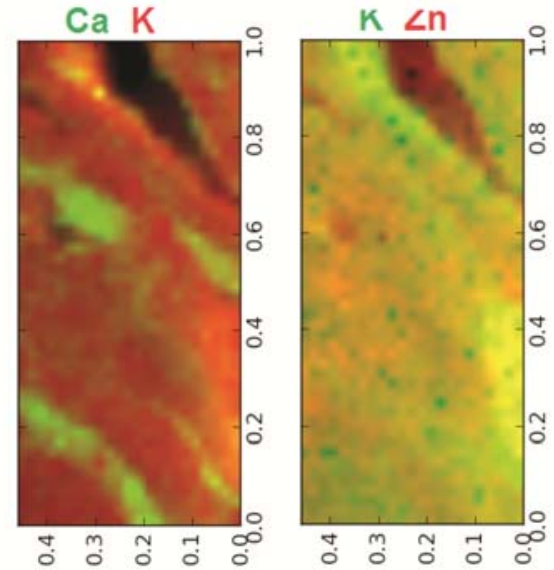

$\mathrm{K} \mathrm{Cu}$
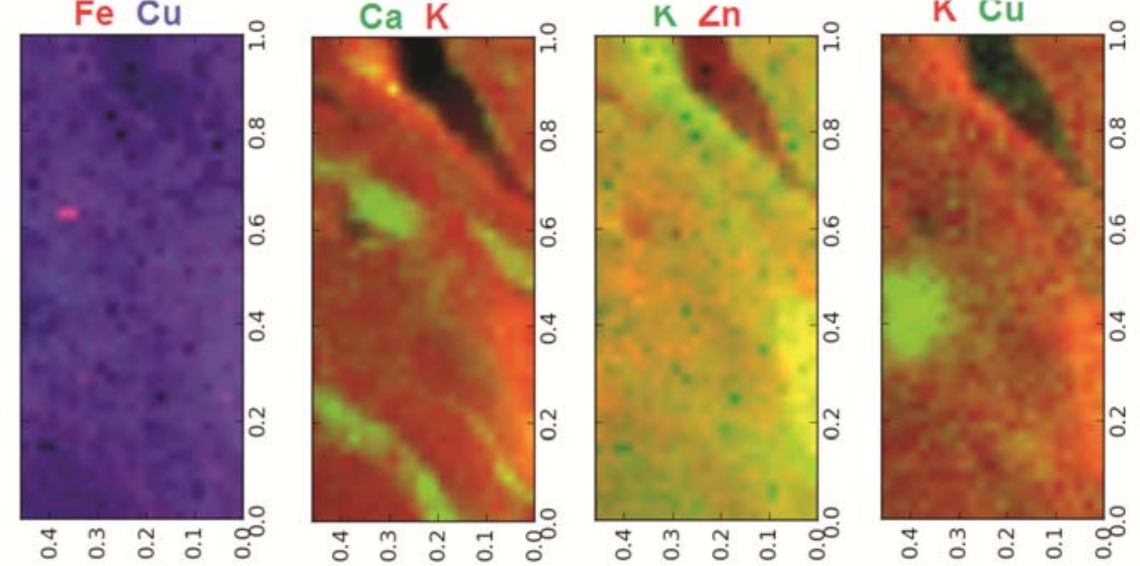

Figura 60 - (A) Imagem vilos cotiledonares de placenta bovina. (B) Mapeamento bidimensional da distribuição elementar (escala em milímetros) em amostra de placentônio por $\mu \mathrm{XRF}$. Barra: $0,5 \mathrm{~mm}$ 


\section{Cotilédone}
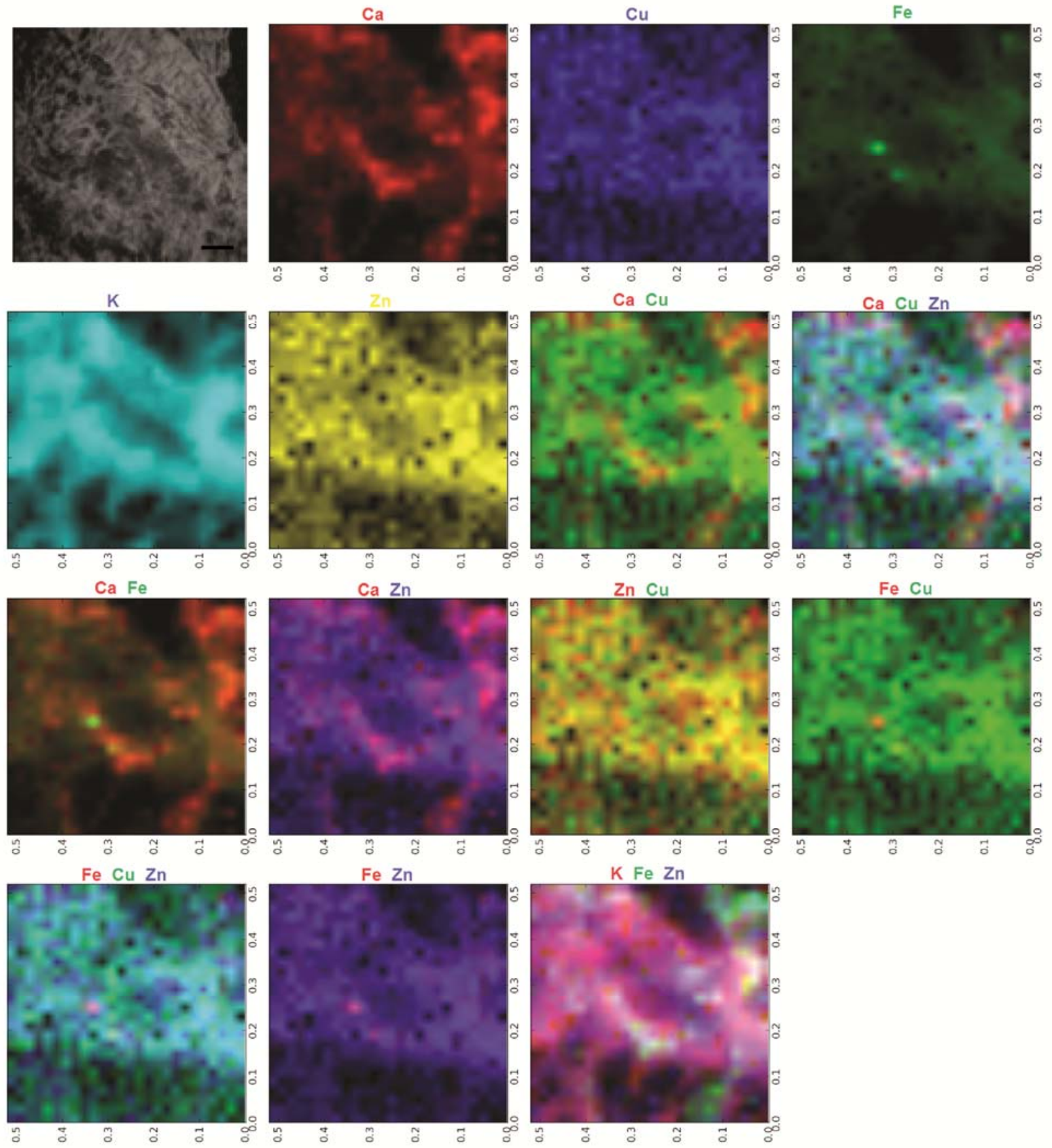

Figura 61- (A) Imagem vilos cotiledonares de placenta bovina. (B) Mapeamento bidimensional da distribuição elementar (escala em milímetros) em amostra de placentônio por $\mu$ XRF. Barra: 0,5 mm 


\section{Região cotilédone}
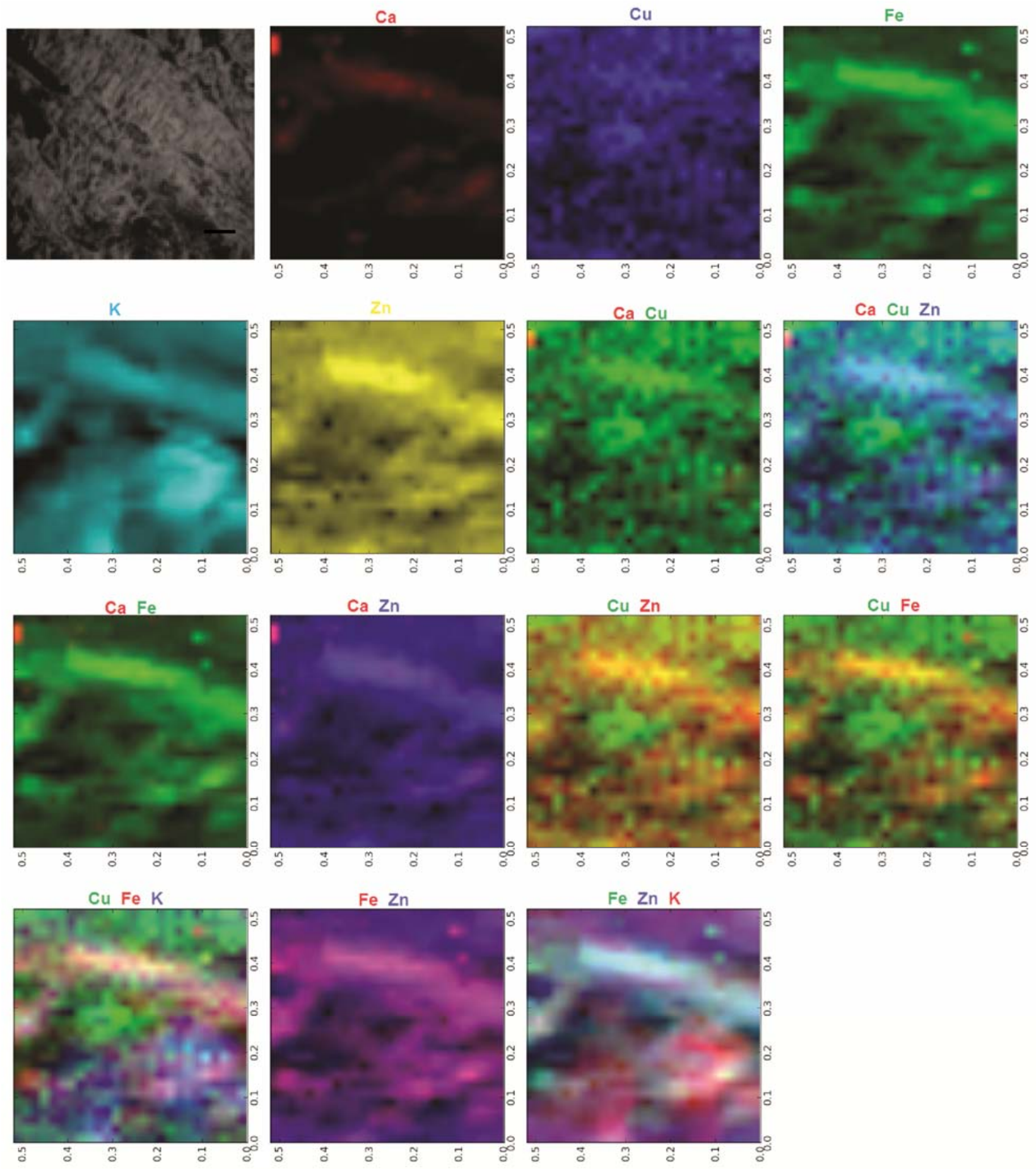

Figure 62 - (A) Imagem vilos cotiledonares de placenta bovina. (B) Mapeamento bidimensional da distribuição elementar (escala em milímetros) em amostra de placentônio por $\mu \mathrm{XRF}$. Barra: $0,5 \mathrm{~mm}$ 
Região interplacentomal
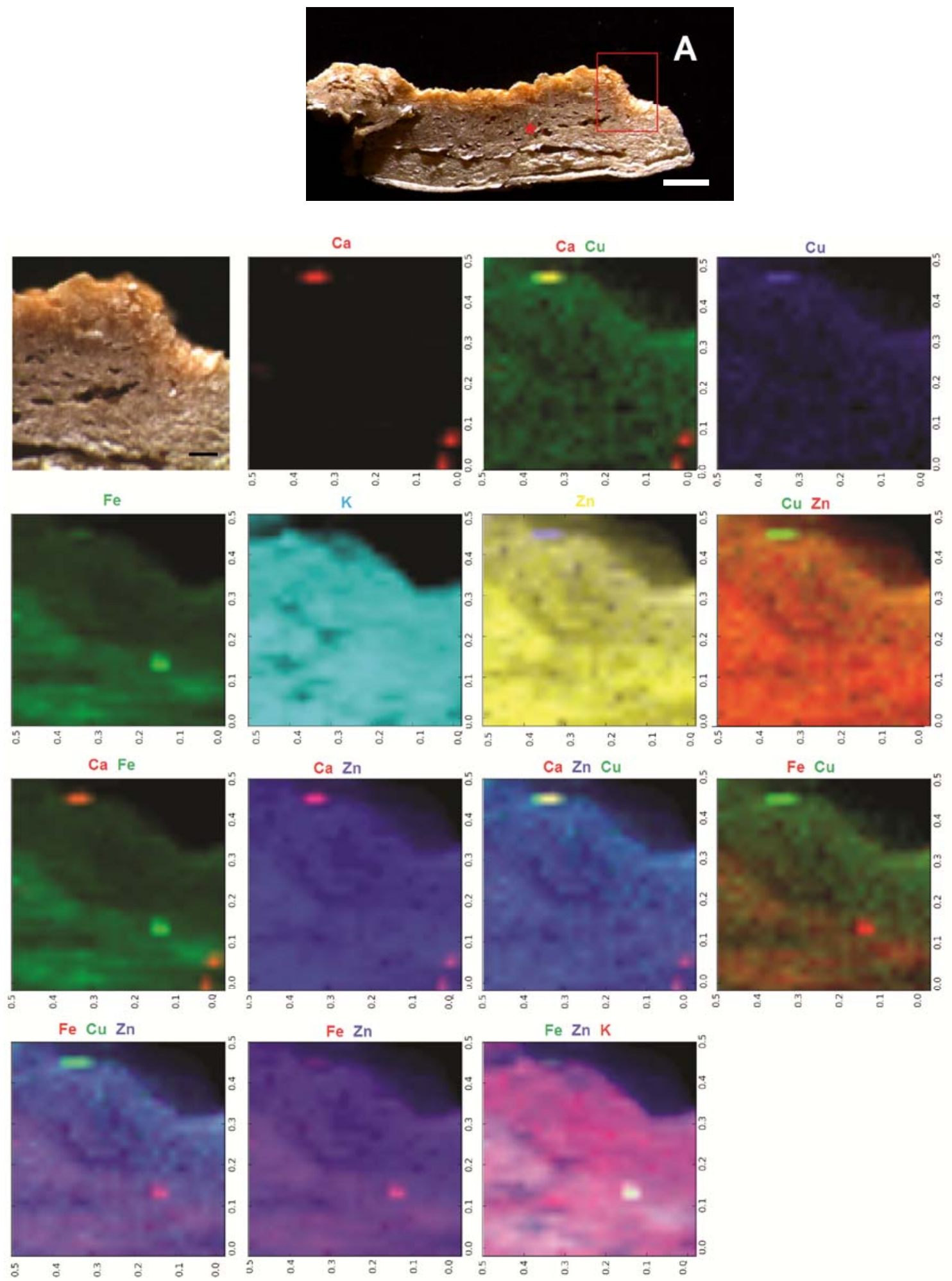

Figure 63 - (A) Imagem da região interplacentomal de placenta bovina região que foi mapeada sinalizada em vermelho. (B) Mapeamento bidimensional da distribuição elementar (escala em milímetros) em amostra de placentônio por $\mu$ XRF. Barra: (A) $1 \mathrm{~cm}$, (B) $0,5 \mathrm{~mm}$ 


\section{Região Interplacentomal}
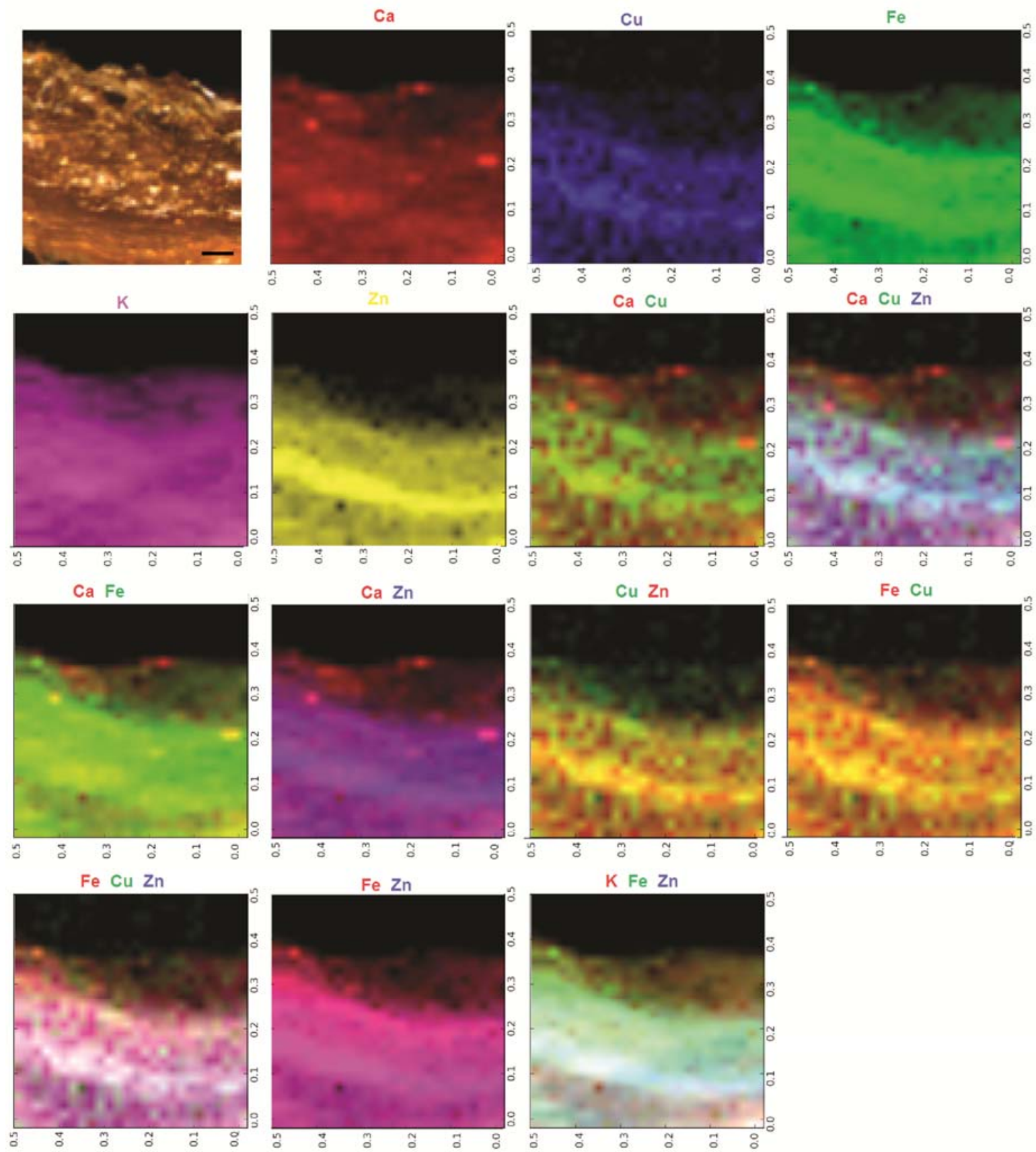

Figure 64 - Imagem da região interplacentomal de placenta bovina. Mapeamento bidimensional da distribuição elementar (escala em milímetros) em amostra de placentônio por $\mu \mathrm{XRF}$. Barra: $0,5 \mathrm{~mm}$ 


\section{Região vasculo- cotiledonária}
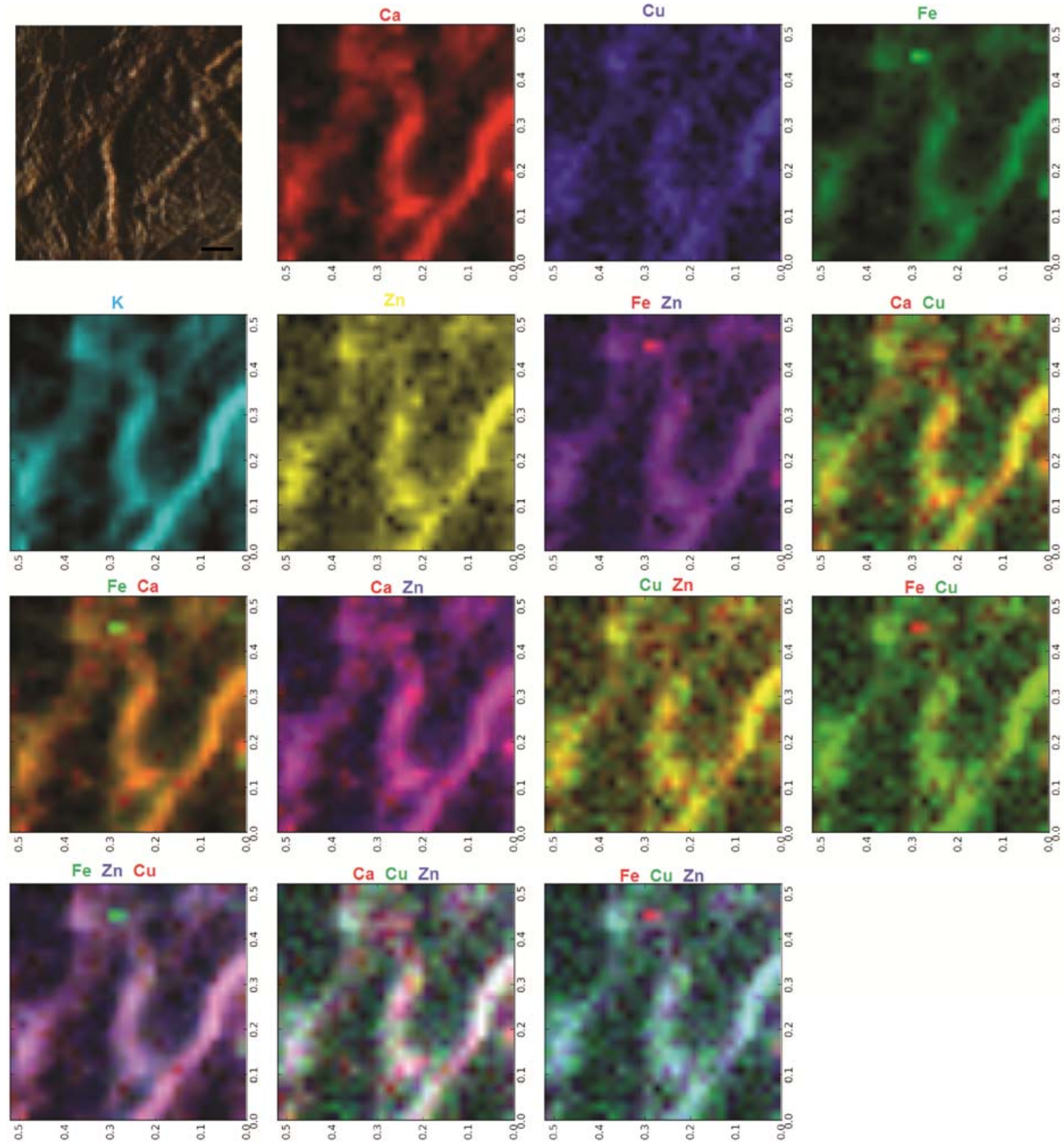

Figure 65 - Imagem dos vasos sanguíneos da região sobre o placentônio. Mapeamento bidimensional da distribuição elementar (escala em milímetros) em amostra de placentônio por $\mu \mathrm{XRF}$. Barra: $0,5 \mathrm{~mm}$ 
Os resultados obtidos neste estudo indicaram que os elementos $\mathrm{Cu}, \mathrm{K}, \mathrm{Cl}, \mathrm{S}, \mathrm{Br}, \mathrm{Zn}$ apresentaram distribuição homogênea sobre toda a superfície observada, os elementos Ca e Fe apresentaram uma distribuição moderada sobre a área estudada com apenas um ponto de alta concentração na região marginal da carúncula. Segundo Cazerta et al. (2007), região conhecida como "zona arcada", esta região é caracterizada pela presença de extravasamento de sangue, com o surgimento de áreas hemófagas, os quais podem estar envolvidos na hematopoiese fetal. Além disso, as áreas hemófagas da placenta bovina parecem ser importantes sítios de transferência de ferro mãe para o feto (WIMSATT, 1950; LATSHAW, 1987; MOSSMAN, 1987; SANTOS et al., 1996; PEREIRA, 2004). Foi observada uma alta interelação $\mathrm{K}-\mathrm{Cu}, \mathrm{K}-\mathrm{Ca}$, a interelação dos elementos está representadas quando ocorre a mudança da cor, pela sobreposição ou fusão das cores originando outra tonalidade representada no anexo B. A interelação K-Zn foi moderada apresentando uma mudança leve na coloração. A região que apresentou maior concentração de $\mathrm{Ca}$, este ponto apresentou uma alta interelação com $\mathrm{Zn}$, representadas pela figura 66 .

Pode-se observar na figura 61, 62 e 63 que a região do cotilédone apresentou maior intensidade elementar nas regiões dos vilos cotiledonários. Os elementos $\mathrm{Cu}, \mathrm{K}, \mathrm{Zn}, \mathrm{Ca}, \mathrm{Fe}$ apresentaram distribuição homogênea sobre a região analisada. $\mathrm{O} \mathrm{Ca}-\mathrm{Cu}$ apresentaram uma alta interelação nas regiões de picos de intensidade, este comportamento foi verificado entre $\mathrm{Ca}-\mathrm{Fe}, \mathrm{Ca}-\mathrm{K}, \mathrm{K}-\mathrm{Cu}, \mathrm{K}-\mathrm{Zn}, \mathrm{K}-\mathrm{Fe}$ mostrando o padrão de mudança de cor quando da interelação segundo anexo B. A interação $\mathrm{Fe}-\mathrm{Cu}$ foi moderada.

$\mathrm{Na}$ região da carúncula mostrada na figura 59 e 60 apresentou uma maior concentração de $\mathrm{Ca}$ e Fe que a amostra da figura 58, mas o mesmo padrão de distribuição homogêneo ocorreu entre as três amostras. O mesmo ocorreu entre as interelações elementares, apresentando maior interação elementar nas regiões marginais da amostra.

$\mathrm{Na}$ região interplacentomal foi observado uma distribuição homogênea $\mathrm{Ca}, \mathrm{Cu}, \mathrm{Fe}, \mathrm{K}$ e $\mathrm{Zn}$ nas duas amostras analisadas, com exceção da figura 64 que apresentou apenas alguns pontos de concentração, sendo um ponto no epitélio endometrial uterino, este ponto apresentou uma interelação alta com $\mathrm{Fe}, \mathrm{Cu}$ e $\mathrm{Zn}$. O maior ponto de interelação ocorreu na região do estroma endometrial, região onde se encontram as glândulas endometriais, ocorrendo uma alta interelação entre $\mathrm{Cu}-\mathrm{Zn}, \mathrm{Ca}-\mathrm{Fe}, \mathrm{Fe}-\mathrm{Cu}, \mathrm{Fe}-\mathrm{Zn}-\mathrm{K}$ e uma interelação moderada Ca-Zn, observados nas figuras 64 e 65.

Durante a gestação, um fluído albuminoso rico em proteínas é liberado na região interplacentomal, entre o epitélio uterino e o córion. Este fluído é absorvido pelo trofoblasto, 
sendo uma importante fonte de nutrientes para o feto (MOSSMAN, 1987; GRAY et al., 2001; DANTZER, 2002).

$\mathrm{O}$ resultado encontrado mostrou que a maior intensidade elementar de $\mathrm{Fe}, \mathrm{Cu}, \mathrm{Zn}$, $\mathrm{K}$ e Ca ocorreu nos vasos sanguíneos, ocorreu uma alta interelação entre $\mathrm{Fe}-\mathrm{Zn}, \mathrm{Ca}-\mathrm{Cu}, \mathrm{Ca}-$ $\mathrm{Fe}, \mathrm{Ca}-\mathrm{Zn}, \mathrm{Cu}-\mathrm{Zn}, \mathrm{Ca}-\mathrm{Cu}-\mathrm{Zn}$, e uma moderada interelação entre Fe-Cu (Tabela 14).

Tabela 13 -A interelação entre os minerais, nas diferentes regiões da placenta de bovino clonado, quando apresentado alterações na concentração quando comparada ao GCO Instituto de Pesquisas Energéticas e Nucleares (IPEN), São Paulo, 2009-2010

\begin{tabular}{llll}
\hline Período & \multicolumn{1}{c}{ IPL } & \multicolumn{1}{c}{ PLC } & PLM \\
\hline 90 dias & $\mathrm{P}>\mathrm{Fe}>\mathrm{K}-\mathrm{Fe}<\mathrm{Zn}$ & $\mathrm{P}>\mathrm{Fe}-\mathrm{P}>\mathrm{Na}$ & $\mathrm{P}>\mathrm{Zn}-\mathrm{P}>\mathrm{Fe}$ \\
& $\mathrm{Fe}<\mathrm{Cu}-\mathrm{Ca}>\mathrm{Fe}$ & $\mathrm{P}>\mathrm{Mg}-\mathrm{K}<\mathrm{Fe}$ & $\mathrm{K}>\mathrm{Cu}-\mathrm{Ca}>\mathrm{Fe}$ \\
& $\mathrm{Ca}>\mathrm{Na}-\mathrm{Ca}>\mathrm{Mg}$ & $\mathrm{Fe}<\mathrm{Cu}-\mathrm{Ca}>\mathrm{Fe}$ & $\mathrm{Ca}>\mathrm{Zn}-\mathrm{Ca}>\mathrm{Na}$ \\
& & $\mathrm{K}>\mathrm{Mg}$ & \\
135 dias & $\mathrm{Fe}<\mathrm{Zn}-\mathrm{Fe}<\mathrm{Cu}$ & $\mathrm{Fe}>\mathrm{Zn}$ & \\
& $\mathrm{Ca}>\mathrm{Fe}-\mathrm{Ca}>\mathrm{K}$ & & \\
& $\mathrm{Fe}<\mathrm{Cu}-\mathrm{Ca}>\mathrm{Zn}>\mathrm{Fe}$ & $\mathrm{K}>\mathrm{Mg}$ & \\
& $\mathrm{K}>\mathrm{Fe}$ & & \\
\end{tabular}

Foi observado que toda a vez que o elemento Fe apresentou taxas mais elevadas no GCL, a taxa de concentração de Ca não diferiu entre os $\mathrm{GCO}$ e $\mathrm{Cl}$, este comportamento foi observado também para o $\mathrm{Zn}$. O $\mathrm{Cu}$ é o $\mathrm{Zn}$ apresentaram o mesmo comportamento. $\mathrm{O}$ mesmo ocorreu entre $\mathrm{P}$ e $\mathrm{Ca}, \mathrm{Ca}$ e $\mathrm{Mg}, \mathrm{Ca}$ e $\mathrm{Cl}, \mathrm{K}$ e Ca.

Segundo Henry e Miles (2000), entre as diversas interelações, podem-se chamar atenção ao sinergismo do cobre $(\mathrm{Cu})$ com o ferro $(\mathrm{Fe})$, cobalto $(\mathrm{Co})$ e fósforo $(\mathrm{P})$ e o forte antagonismo do cálcio $(\mathrm{Ca})$ e zinco $(\mathrm{Zn})$ com diversos minerais, assim como, o antagonismo do molibdênio (Mo) e enxofre (S) com o $\mathrm{Cu}$. Os minerais são muito mais propensos a interagir com outros minerais, devido á sua instabilidade e tendência a formar ligações químicas. Essa interelação também foi relatada por O’Dell (1997) e descrita por Georgievskii (1982) que descreveu 16 interelações sinergéticas entre 15 elementos minerais necessários (Figura 67). Podendo ter uma interação direta entre os elementos processos estruturais tais como a necessidade do $\mathrm{Cu}$ juntamente com o $\mathrm{Fe}$ para a formação da hemoglobina, 
participação simultânea no centro ativo de algumas enzimas. A atuação de $\mathrm{Cu}$ e $\mathrm{Fe}$ na citocromo oxidase. Competição para as ligações com substâncias carreadoras no sangue. Ex.: Fe com o $\mathrm{Zn}$ e o $\mathrm{Cu}$ nas ligações com a transferinas plasmáticas.

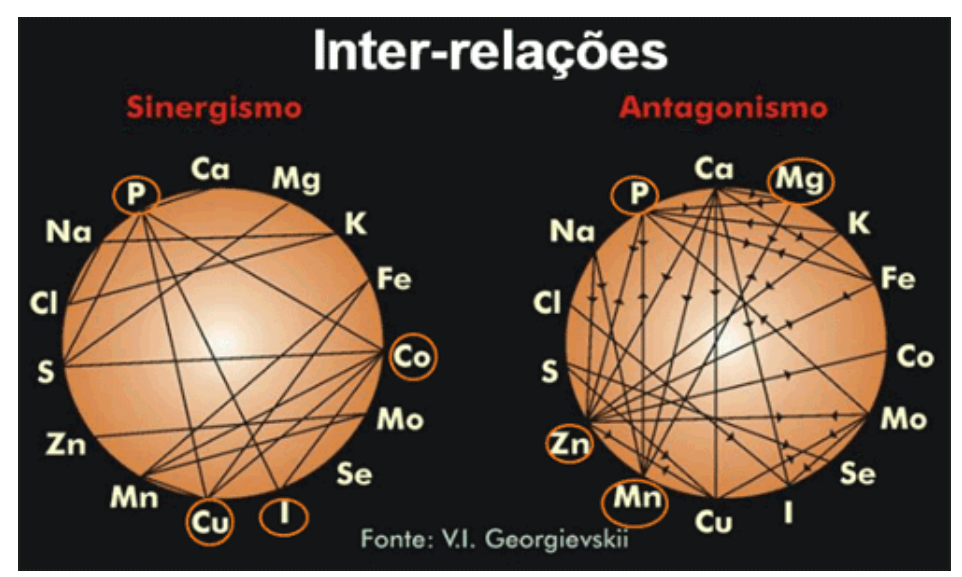

Figura 66 - Figura que ilustra as relações de antagonismo e sinergismo dos minerais iônicos

No trabalho de Bremner et al. (1987); Gengelbach et al. (1994) observaram que ocorreu diminuição na absorção de Zn na presença de uma dieta com alta concentração de Ca.

No trabalho de Carvalho et al. (2001), uma relação entre o peso ao nascimento e as concentrações elementares e o resultado obtido indicou que os níveis de cálcio são maiores para crianças mais pesadas, em contrapartida os elementos $\mathrm{Fe}$ e $\mathrm{Cu}$ mostram uma correlação negativa, diminui quando peso do bebê aumenta. Nesse estudo foram analisadas nove placentas sendo seis delas obtidas por intervenção vis fórceps. O $\mathrm{Zn}$ também foi correlacionado em seu trabalho, indicando o peso reduzido ao nascer e sendo relacionado ao retardo no crescimento fetal.

Sutmoller et al. (1966), estudando mortes de evolução super-aguda ("morte súbita") na Região Amazônica, que denominaram "mal-de-cai”, concluíram que elas fossem causadas por um distúrbio mineral alimentar,decorrente as carência de sódio e potássio, associado a um desequilíbrio $\mathrm{Ca} / \mathrm{P} / \mathrm{Mg}$ no soro, caracterizado por valores séricos aumentados de magnésio, relativamente altos de fósforo e diminuído de cálcio. 


\section{CONCLUSÃO}

Os minerais são essenciais para o desenvolvimento embrionário e fetal. Para cada elemento existe uma faixa de concentração ótima para resguardar o funcionamento e a integridades dos tecidos, em níveis de exigências adequados as necessidades de um organismo. Os resultados obtidos para a microfluorescência de raio X usando Síncrotron permitiu-nos identificar quais são os elementos traço determinantes na troca de informações entre o feto e a mãe. Os mapas dimensionais apontaram para áreas com maior transporte de nutrientes e a atuação dos elementos traço em períodos gestacionais.

A microfluorescência de raios $\mathrm{X}$ foi eficaz na análise dos mapas bidimensionais das concentrações das regiões dos placentônios e regiões interplacentomal, os resultados desta pesquisa confirmam que a maior concentração elementar ocorreu na região de interdigitação entre as criptas carunculares do epitélio uterino e as vilosidades cotiledonária com células trofoblásticas na região dos placentônios e nas glândulas endometriais da região interplacentomal. Nestas regiões ocorrem as trocas de nutrientes, evidenciando e indicando a presença de regiões funcionais especializadas na placenta. Foi possível demonstrar nos mapas, a existência deinterelação entre diversos minerais, demonstrando competição pelo mesmo sítio de absorção de acordo com a literatura existente.

Com relação aos níveis de concentração elementar por EDXRF observou-se as concentrações de $\mathrm{Fe}, \mathrm{Cu}, \mathrm{Zn}, \mathrm{P}$, Se variaram com o período gestacional e entre as regiões distintas da placenta. Os elementos $\mathrm{Na}, \mathrm{Mg}, \mathrm{P}, \mathrm{Cl}, \mathrm{K}$ e $\mathrm{Ca}$ apresentaram maiores concentrações para GCL. Nas concentrações de Fe e $\mathrm{Mg}$ a diferença não foi significativa, com exceção do Fe que no GCL houve uma aumento na concentração na região do placentônio, que apresentaram valores significativamente distintos

Os elementos $\mathrm{Cu}$ e $\mathrm{Zn}$ não apresentaram diferenças significativas entre GCO e GCL. Não foi possível detectar com precisão os elementos Se, Mo e Co que deverão ser avaliados por outra técnica experimental que tenha limites de detecção mais adequados. Este estudo permitiu-se identificar elementos presentes e atuantes nos estágios gestacionais com concentração variáveis para os grupos em análise. 
Sieferéncias 


\section{REFERÊNCIAS}

ABUTARBUSH, S. M.; RADOSTITS, O.M. Congenital nutritional muscular dystrophy in a beef calf. Canadian Veterinary Journal, v.44, n. 9, p. 37-46, 2003.

AITKEN, R. J.; BURTON, J.; HAWKINS, J.; KERR-WILSON, R.; SHORT, R. V.; STEVEN, D. H. Histological and ultra structural changes in the blastocyst and reproductive changes in the blastocyst and reproductive tract of the roedeer, Capreolus capreolus, during delayed implantation. Journal of Reproduction and Fertility, v. 34, p. 481-493, 1973.

ALMEIDA, J. M.; SANTOS, R. M.; MIGLINO, M. A.; MORAIS-PINTO, L. Morfologia do funículo umbilical em ovinos deslanados mestiços (Ovies àries, L. 1758). Brazilian journal veterinary. Research and Animal Science, v. 37, n. 7, p. 189-193, 2000.

ALVES, A. B.; ARANTES, V. M.; MUNDIM, A.V. Metabolismo do ferro em suínos. Artigo de pesquisa do programa PIBIC/UFU/ CNPQ . Revista FAMEV, UFU, CP 593, v. 38, n.4, p. 400- 902, 2006.

AMORIM, S. L.; OLIVEIRA, A. C. P.; RIET-CORREA, F.; SIMÕES, S. V. D.; MEDEIROS, R. M. T.; CLEMENTINO, I, J. Distrofia Muscular nutricional em ovinos na Paraíba. Pesquisa Veterinária Brasileira, v. 25, n. 2, 2005.

ANJOS, M. J.; BARROSO R. C.; PÉREZ, C. A.; BRAZ, D.; MOREIRA, S.; DIAS, K. R. H. C.; LOPES, R. T. Elemental mapping of teeth using $\mu$ SRXRF Nuclear Instruments and Methods in Physics Research Section B. v. 213, p. 569-573,January 2004.

ATKINSON, D. E.; BOYD, R. D. H.; SIBLEY, C. P. Placental transfer. Knobil and Neill's Physiology of Reproduction, c.52, p.2786-2846, 2006.

BARCELLOS, J.O.J.; PRATES, E.R.; OSPINA, H. Suplementação mineral de ruminantes nos campos nativos de Rios Grande do Sul: uma abordagem aplicada a pecúaria de corte. In: BARCELLOS, J.O.J.; OSPINA, H.; PRATES, E.R. $1^{\circ}$ Encontro anual sobre nutrição de ruminantes da UFRGS - Suplementação mineral de bovino de corte, São Gabriel, Gráfica da UFRGS, Porto Alegre, p.81-110, 1990.

BARCKLA, C., “ The spectro of the fluorescent rontgen radiation”. Medical Physics,.v. 22, p. 396-412, 1911.

BECKER, J. S., ZORIY, M.V.;PICKHARDI, C. et al. " Imaging of copper, zinc, and other elements in thin section of human barin samples (hippocampus) by laser ablantion inductively". Analytical Chemistry. v. 77, p. 3208-3216, 2005.

BEHMER, O. A.; TOLOSA, E. M. C.; FREITAS NETO, A. G. Manual de técnica para histologia normal e patológica. São Paulo: Edart, EDUSP, 1976, p. 259.

BENNETS, H. W.; CHAPMAN, F. E. Copper deficiency in sheep in Western Australia . A preliminary account of the etiology of enzootic ataxia of lambs and anemia of ewes, Australian Veterinay Journal, v.13, p. 138, 2003. 
BERGER, L. L. Trace Minerals and Reproduction in Livestock.University of Illinois, Salt and Trace Minerals, v. 36, n. 2 , p. 56-76, 2004.

BERNANSCONI, G.; HASELBERGER, N.; MARKOWICZ, A. " Aplication of a capillary based X-Ray microfluorescence system". Nuclear Instruments and Methods in Physics Research B, v. 86, p. 333-338, 1994.

BERTIN, E. P. Principles and practice of $\mathbf{X}$-ray spectrometric analysis. New York: Plenum Press, 1970.

BERTOLO, R. F. P.; BETTGER, W. J.; ATKINSON, S. A. Divalent metals inhibit and lactose stimulates zinc transport across brush border membrane vesicles from piglets. Journal of Nutritional Biochemistry, Montevale, v. 12, n. 2, p. 73-80, 2001.

BISSONNETTE, J.M.; HOHIMER, A.R; CRONAN, J.Z.; and BLACK, J.A. Glucose transfer across the intact guinea-pig placenta. Journal Dev. Physiology, v. 1, p. 415-426, 1979.

BOHIC S.; SIMIONOVICI A.; ORTEGA R.; HEYMANN D.; SCHROER C.;SNIGIREV A. Synchrotron-induced X-ray microfluorescence on single cells. Nuclear Instruments and Methods in Physics Research Section B: Beam Interactions with Materials and Atoms, v. 181 , n. 1-4, p. 728-733, July 2001.

BOUMANS, P.; KLOCKENKÃMPER, R. (Ed.) - Total reflection X-ray fluorescence spectrometry. Trabalho apresentado Proc. of the Second Workshop on TXRF, Dortmund, 2627 May, 1988. Acta Spectrochin Part B, v. 44,p. 433,1989.

BRADLEY, B. D.; GRABER, G.; CONCON, R. J.;FROBISH, L. T. Effect of graded levels of dietary copper on copper and iron concentration in swine tissues. Journal of Animal Science, Savoy, v. 56, p. 625-632, 1983.

BREMMER, I.; HUMPHTIES, W. R.; PHILLIPPO, M.; WALTER, M. J.;MORRICE, P. Iron- induced copper deficiency in calves: dose-response relationship and interactions with molybdenum and surfur. Animal Production, v. 45, p. 403-410, 1987

BURK R. F. Biological activity of selenium. Annual Veterinay Nutrition.v. 3,p. 53-70, 1983.

CAMPBELL, A.; SMITH, M. A.; SAYRE, L. M. Mechanisms by witch metals promote events connected to neurodegeneration diseases. Brain research Bielletin, v. 55, n. 2, p. 125-132, 2001.

CANÇADO, R. D.; CHIATTONE, C. S. Aspectos atuais do Metabolismo do ferro. Revista Brasileira de Medicina. 2003. Disponível em: www. cibersaude.com.br/revista. asp? fase $=$ r003\&id_materia=1684. Acesso em: 23 mar. 2009.

CANELlAS, C. G. L; CARVALHO, S. M. F.; JESUS, E. F. O.; ANJOS, M. J.; LOPES, R. T. " Trace and major Elements in Serum of patients with chronic myelogenous leukemia", Journal of Radioanalytical and Nuclear Chemistry, v. 269, n.3, p. 631-634, 2006. 
CARVALHO, A.; KLISCH, K.; MIGLINO, M. A.; PEREIRA, F. T.; BEVILACQUA, E. Binucleate trophoblast giant cells in the water buffalo (Bubalus bubalis) placenta. Journal of Morphology, v.267, n. 1, p. 50- 56, 2006.

CARVALHO, M.; CUSTODIO, P.; REUS,U.; PRANGE, A. “ Elemental Analysis of Human Amniotic Fluid and Placenta by Total-Reflection X- Ray Fluorescence and EnergyDispersive X-Ray Fluorescence: Chil Weight and Maternal Age Dependence", Spectrochin Acta Part B v.56, p. 2175-2180, 2001.

CAZERTA S. M. M., MIGLINO M. A., MARQUES R. S., VULCANO M.; PEREIRA F. T. V. Caracterização das áreas hemófagas da placenta bovina. Pesquisa Veterinária Brasileira, v. 27, n. 6, p. 229-235, jun. 2007.

CHANDRA, R. K. Nutrition and the immune system: an introduction. The American Journal of Clinical Nutrition, v. 66, n. 2, p. 460S-463S, 1997.

CHASTON, T. CHUNG, B.; MASCARENHAS, M.; MARKS, J.; PATEL,. SRAI,S. R.; SHARP, P. Evidence for differential effects of hepcidin in macrophages and intestinal epithelial cells. GUT, v. 57, p. 374-382, 2008.

COCATO, M. L.; TRINDADE NETO, M. A.; BERTO, D. A.; RÉ, M. I.; COLli, C. Biodisponiblidade de ferro em diferentes compostos para leitões desmamados aos 21 dias de idade. Revista Brasileira Zootecnia, v.37, n. 12, p. 2129-2135, 2008.

CONRAD, J. H.; MCDOWELL, L. R.; ELLIS, G. L.; LOOSLI, J. K. Minerais para ruminantes em pastejo em regiões tropicais. Gainesville: University of Florida, 1985, p.90.

CONSTANT, F.; GUILlOMOT, M.; HEYMAN, Y.; VIGNON,X.; LAIGRE, P.; SERVELY, J. L.; RENARD, J. P.; CHAVATTE-PALMER, P. Large offspring or large placenta syndrome. Morphometric analysis of late gestation bovine placentomes from somatic nuclear transfer pregnancies complicated by hydrallantois. Biology of Reproduction, v. 75, p. 122-130, 2006.

CHORNOCK, C. Effect of manganese on calcification in the growing rat. Journal Nutriton, v.3, p. 445, 1942.

COZZOLINO, S.M.F. Biodisponibilidade de nutrientes. Barueri: Manole, 2005. c. 22, p. 459.

CUNNINGHAM, J. G. Tratado de Fisiologia Veterinária. $3^{\circ}$ edição, p.1331-1403, 2004.

DAL PAI , V. Histoenzimologia: Teoria e Prática. Botucatu: Instituto de Biociências Unesp, 1995.

DANTZER, V. Epitheliochorial placentation. In: KNOBIL, E.; NEILL, J.D. Encyclopedia of reproduction. San Diego: Academic Press, 1999, v. 1, p. 18-28.

DOWNS, S. H.; DURR, P.; EDWARDS, J.; CLIFTON-HADLEY, R.,. Trace micronutrients may affect susceptibility to bovine tuberculosis in cattle. Preventive Veterinary Medicine, v. 87, p. 311-326, 2008.

DUNN, L. L.; RAHMANTO, Y. S.; RICHARDSON, D. R. Iron uptake and metabolism in the new millwnnium. Trends in cell biology, v. 17, n. 2, p. 93 -100, 2006. 
EICHHORN, K. H.; BAUER, C.; ECKARDT, K. U.; ZIMMERMANN, R.; HUCH A; $\mathrm{HUCH}, \mathrm{R}$. Lack of associations between fetal and maternal serum-erythropoietin at birth. Europen Journal Obstetic Gynecology Reproduction Biology, v. 50, p. 47-52, 1993.

EISBERG, R.; RESNICK, R.; Física quântica átomos, moléculas, sólidos, núcleos e partículas. 7 ed. Rio de Janeiro: Campus, 1988.

EMBRAPA. Desordens que podem ocorrer no organismo da vaca leiteira após o parto por nutrição inadequada -2009- Disponível em: www.cnpgl.embrapa.br/nova/sala/artigos/artigolinha.php?id=31. Acesso 12/02/2009 as 17:09

EMERIT, J.; EDEAS, M.; BRICAIRE, F. Neurodegenerative diseases and oxidative stress. Biomedicine \& Pharmacotherapy, v. 58, pp. 39-46, 2004.

ENOMOTO, S.; HIRUNUMA, R. Fetoplacental transporto various trace elements in pregnant rat using the multitracer technique. New trends in Bio- Trace Elements Research, v. 35 , p. 236-247, 2001.

EUCLIDES, V. P. B.; MEDEIROS, S. R. Suplementação Animal em Pastagens e seu Impacto na Utilização da Pastagem. In: TEORIA E PRÁTICA DA PRODUÇÃO ANIMAL EM PASTAGENS, 2005, Minas Gerias, Anais..., p. 33-70.

FERGUSON, J. D. Nutrition and reproduction in diary cows. In: The Veterinary Clinics of North America: Food Animal Practice. Dairy Nutrition Management, v. 7, n. 2, p.483-507, 1991.

FERREIRA, A. M. Nutrição e atividade ovariana em bovinos: uma revisão. Pesquisa Agropecuária Brasileira, v. 28, n. 9, p. 1077-1093, 1993.

FISHER, G. E. J.; MCPHERSON, A. Serum vitamin b 12 and methylmalonic acid Determinations in the diagnosis of cobalt deficiency in pregnant ewes. British Veterinary Journal, v. 7, p. 120-146, 1990.

FLEMMING, J. S. Por que usar ferro orgânico para suínos. 2007. Tecnologia aplicada a nutrição Disponível em $\leq$ www.suino.com.br/nutricaonoticia.aspx? codigonot=a/zwoevnfyq $>$. Acesso em: fev. 2009.

FLETCHER, J. Trace Mineral for Beef Cows. Agriculture and rural development. (2002). Disponivel em: <www.1.agric.gov.ab.ca/\$department/deptdocs.nsf/all/beef4887>. Acesso em: abr. 2009.

FLOHÉ, L.; GUNZLER, W. A.; SCHOCK, H. H. Glutathione peroxidase: a selenium enzyme. FEBS Letter, v.32, p. 132-134, 1973.

GENGELBACH, G. P.; WARD and J. W, Spears, Effects of copper deficiency and copper deficiency coupled with high dietary iron or molybdenum on phagocytic cell function and response of calves to a respiratory disease challenge. Jounal Animal Science.v. 75, p. 1112$1118,1997$. 
GEORGIEVSKII, V. I.; ANNEKOV, B. N.; SAMOKHIN, V. T. Mineral nutrition of animals. London: Butterworth, 1982, p. 11-56.

GIPP, W.F.; POND, W.G.; KALLIRONLZ, F.A.; TASKER, J.B.; VANKAMPEN, D.R.; KROOK, L.; VISEK, W.J. Effect of dietary copper, iron and ascorbic acid levels on hematology, blood and tissue copper, iron and zinc concentrations and marked $\mathrm{Cu}$ and Iron metabolism in young pigs. Journal of Nutrition, Rockville, v. 104, p. 532-539, 1974.

GODFREY, K. M.; BARKER, D. J. P. Fetal nutrition and adult disease. The American Journal of Clinical Nutrition, v. 71, n. 5, p. 1344S-1352S, 2000, Suplement.

GRAY, C. A.; BARTOL, F. F.; TARLETON, B. J.; WILWY, A.A.; JOHNSON, G.A.; BAZER, F.W.; SPENCER, T. E. Developmental biology of uterine glands. Biology of Reproduction, v. 65, p. 1311-1323, 2001b.

GRAY, C. A.; TAYLOR, K. M.; RAMSEY, W. S.; HILL, J. R.; BAZER, F. W.; BARTOL, F. F.; SPENCER, T. E. Endometrial glands are required for preimplantation concneptus elongation and survival. Biology of Reproduction, v. 64, p.1608- 1613, $2001 \mathrm{a}$.

GUÉRIN, P.; EL MOUATASSIM, S.; MÉNÉZO, Y. Oxidative stress and protection against reactive oxygen species in the preimplantation embryo and its surroundings. Human Reproduction Update, v.7, n.2, p.175-189, 2001.

GUR, A.; KARAKOC, K. N.; CQEVIK, R.; SARAC, J.; SARAC, J.; DEMIR, E. E.: Efficacy of low power lases therapy in fibromyalgia: A single-blind, placebo-controlled trial.

Laser Medicine Science, v. 17, p. 57-61, 2002.

HAFEZ, E. S. E.; HAFEZ, B. Reprodução Animal. 7 ed. São Paulo: Manole, 2004.

HAFEZ, S. Reprodução Animal. São Paulo: Manole, 1982. p. 582.

HAFEZ, S. The placentoma in the buffalo. Acta Zoologica. V. 35, pp.177-191, 1954.

HALL, A .J. A.; VAN SAUN, R. J.; NICHOLS, T.; MOSHER, W.; PIRELLI, G. Comparison of selenium status in sheep after short-term exposure to high-selenium-fertilized forage or mineral supplement. Small Ruminant Research, v. 82 , p. 40-45, 2009.

HANSON, A. L.; JONES, K.W.;GORDON, B. M.; et al. " Trace elements measurement using with syncrotron radiation." Nuclear Instrument and Methods in Physics Research B, v. 24/25, p. 400-404, 1987.

HAVRILLA, G. J. Applications of X-Ray microfluorescence to material analysis. X-Ray Spectrometry, v. 26, p. 364-373, 1997.

HARTMAN, R. H.; MATRONE, G.; WISE, G. H. Effect ofhigh dietary manganese on hemoglobin formation. Journal Nutrition, v. 57, p. 429-439, (1955).

HAWK, S. N.; LANOUE, L.; KEEN, C. L.; KWIK-URIBE, C. L.; RUCKER, R. B.; UriuAdams JY. Copper-Deficient Rat Embryos Are Characterized by Low Superoxide 
Dismutase Activity and Elevated Superoxide Anions. Biology of Reproduction ,v. 68 , p. 896-903, 2003.

HENRY, P. R.; MILES, R. D. Relative trace mineral bioavailability. Ciência Animal Brasileira .v. 1, n. 2, p. 73-93, 2000.

HIDIROGLOU, M. Trace element deficiencies and fertility in ruminants: a review. Journal of Dairy Science, v. 62, p. 1195-1206, 1979.

HIDIROGLOU, M. Trace Elements in the Fetal and Neonate Ruminant: A Review Willard, Hobart H. Instrumental methods of analysis, 7th. ed. California: Belmont, 1988

HILL, J. R.; BURGHARDT, R. C.; JONES, K.; LONG, C. R.; LOONEY, C. R.; SHIN, T.; SPENCER, T. E.; THOMPSON, J. A.; WINGER, Q. A.; WESTHUSIN, M.E. Evidence for placental abnormality as the major cause of mortality in first trimester somatic cell cloned bovine fetuses. Biology of Reproduction, Champaign, v. 63, p. 1787-1794, 2000.

HOSTETLER, C. E.; KINCAID, R. L.; MIRANDO, M. A.; The role of essential trace elements in embryonic and fetal development in livestock. Veterinary Journal, v. 166, n. 2, p. 125-139, 2003.

HOYES, A. D.The endometrial glands of the pregnant sheep: an ultrastrutural study. Journal of Anatomy, v. 111, n. 1, p. 55-67,1972.

HURLEY, W.C.; DOANE, R. M. Recent developments in the roles of vitamins and minerals in Reproduction. Jounal Dairy Science, corporalutea and follicular fluid. J. Dairy Sci., v. 67, p.1316, 1984.

IAEA: Quantitative X-Ray analysis system (QXAS) software package, Viena: IAEA 1978.

IBGE. INSTITUTO BRASILEIRO DE GEOGRAFIA E ESTATÍSTICA. Anúario estatístico, 2006.

JAINUDEEN, M. R.; HAFEZ, E. S. E. Gestação, fisiologia pré-natal e parto. In: HAFEZ, E.S.E. Reprodução Animal. 6. ed., São Paulo: Manole, 1995, p. 141-155.

JANSSENS, K.; VINCZE, L.; ADAMMS, F.; “ Synchrotron radiation induced X-Ray microanalysis", Analytic Chimica Acta, v. 283, p. 98-119, 1993.

JOHNSON, R. F.; HERMAN, N.; ARNEY, T. L.; JOHNSON, H.V.; PASCHALL, R. L. ; DOWNING, J. W;. The placental transfer of sufentanil: effects of fetal $\mathrm{pH}$, protein binding, and sufentanil concentration. Anesthesia Analgic, v. 84, p. 1262-1268, 1997.

JOHNSTON, A. E. Essential trace elements for plants, animals and humans. Trace elements in soil: Status and Management. NJF. Seminary, n. 370, p. 15-17, 2005.

JUNQUEIRA , L. C.; CARNEIRO, J. Histologia básica. Rio de Janeiro: Guanabara Koogan, 1995. 
KAVAZIS, N. A.; KIVIPELTO, J.; OTT, E. A. Supplementation of broodmares with copper, zinc, iron, manganese, cobalt, iodine, and selenium. Journal of Equine Veterinary Science, v. 22, n. 10, p. 460-464, 2002.

KEEN, C. L, URIU-HARE, J. Y.; HAWK, S. N.; JANKOWSKI, M. A.; DASTON, G. P.; KWIK-URIBE, C. L.; RUCKER, R. B. Effect of copper deficiency on prenatal development and pregnancy outcome. The American Journal of Clinical Nutrition, v. 67, n. 5, p. 1003S-1011S, 1998, Suplement.

KHALILI, H.; SOUDBAKHSH, A.; HAJIABDOLBAGHI, M.; DASHTI-KHAVIDAKI, S.; POORZARE, A.; SAEEDI, A.A.; SHARIFIFAR, R. Nutritional status and serum zinc and selenium levels in Iranian HIV infected individuals. BMC Infectious Diseases, v. 8, p. 165, 2008, doi:10.1186/1471-2334-8.

KING, G. J.; ATKINSON, B. A. The bovine intercaruncular placenta throughout gestation. Animal Reproduction Science, v. 12, p. 241-254, 1987.

KNOCKENKAMPER, R. Total Reflection X-Ray Fluorescence analysis. Dourtmund, Germany Institut fur Spectrochime und Angewante Spekhoskopie, 1996, v. 140.

KNOLL, G. F. Radiation detection and measurement. 3. ed, New York: John Wiley \& Sons, 1999.

KOTZ, C.I. and TREICHEL, P. R. Química e reações químicas. 4. ed. Rio de Janeiro: LTC, 2002, v.1.

LATSHAW, W. K. Veterinary developmental anatomy. A clinically oriented approach. Toronto, Canadá B.C. Decker, 1987, p. 283.

LEISER, R.; KAUFMAN, P. Placental structure: in a comparative aspect. Experimental and Clinical Endocrinology, 102 (3): 122- 134, 1994.

LEISER, R.; KREBS, C.; KLISCH, K.; EBERT, B.; DANTZER, V.; SCHULER, G.;

HOFFMANN, B. Fetal vilosity and microvasculature of the bovine placentome in the second half of gestation. Journal of Anatomy. v. 191, p. 517-527, 1997.

LINDGREEN, E. S. X-Ray fluorescence analysis: energy dispersive. In: MEYERS, R.A. (ed). Enciclopedia of analytical chemistry. Chichester: John Wiley \& Sons, 2000, c.. 1, p.1-12.

LINDH, U. "Nuclear Microscopy. Its role and future in Medicine and trace- element biology". Nuclear instruments and methods in Physics Research 3, v. 54, pp. 160-170, 1991.

LOBÃO, A.O. As deficiências em bovinos. Jornal "O Estado de São Paulo"- SÃO PAULO/SP - Suplemento Agrícola. 1083, p. 11, 1976.

LOTTHAMMER, K. H. Transtorno de la fertilidad de origen ambiental. In: GRUNET, E.: BERCHTOLD, M. Infertilidad en la vaca. Buenos Aires: Hemisférico Sur, p.385-375, 1988. 
.MAENHAUT, W.; HEBBRECHT, G.; DEREUCK, J. Examination of the regional distribuition of minor and elements in normal human brain by PIXE and chemometric techniques. Nuclear Instruments and Methods in Physics Reserch B, v. 75, p. 180-187, 1993.

MARCÓ, L. M. P., CARABAllo, E. A. H, PASCUSSO, C.; AlVARADA, J. ., "Determination of manganês in braisn samples by slurry sampling graphite furnace atomic absorption spectrometry" Talanta, v. 59, n. 5, p. 897-904, 2003.

MARQUES, A. F.; MARQUES, J. P.; CASACA C.; CARVALHO M. L. X-ray microprobe synchroton radiation X-ray fluorescence application on human teeth of renal insufficiency patients. Spectrochimica Acta Part B. v. 59, p. 1675- 1680, 2004.

MATAlOUN, M. M. G. B.,; LEONE, C. R. Peculiaridades do metabolismo de cálcio e fósforo no período perinatal: análise crítica de literatura. Revista de Pediatria. V. 20, p. 332-384, 2007.

MAYHEW, T.M. Fetoplacental angiogenesis during gestation is biphasic, longitudinal and occurs by proliferation and remodelling of vascular endothelial cells. Placenta, v. 23, p. 742-750, 2002.

MCDOWELL, L. R. Minerals in animal and human nutrition. San Diego: Academy Press, 1992, p. 524.

MCDOWELL, L.R. Minerais para ruminantes sob pastejo em regiões tropicais, enfatizando o Brasil. 3. ed., Flórida: University of Florida, 1999 p. 92.

MCPHERSON, A.; GRAY, D.; MITCHELL, G. B.; TAYLOR, C. N. Ostertagia Infection And Neutrophil Function In Cobalt-Deficient And Cobalt - Supplemented Cattle. v. 1, p. 143-348, 1987.

MEGLiA, G. E.; HOLTENIUS, K.; PETERSSON, L.; ÖHAGEN, P.; PERSSON, K..;WALLER, A .Prediction of Vitamin A, Vitamin E, Selenium and Zinc Status of Periparturient Dairy Cows Using Blood Sampling During the Mid Dry Period - Acta veterinay Scandary, v. 45, p. 119-128, 2004.

MERTZ, W. E. Chromium occurence and function in biological systems. Physiology Reviews, Baltimore, v. 49, p. 163-239, 1969.

MIGLINO, M. A. Pesquisa anatômica sobre a ramificação e distribuição das artérias e veias da placenta de bovino. Tese (Livre Docência) - Faculdade de Medicina Veterinária e Zootecnia, Universidade de São Paulo, São Paulo, 1991.

MILLER, J. K.; RAMSEY N, MADSEN E. F. C. The trace elements. In: D.C. CHURCH. The Ruminant Animal. Digestive Physiology and Nutrition. Waveland Press, 1993, p. 342-400.

MOODY, J. " The sampling, handling and storage of materials for trace analysis", Philosophical Transaction of the Royal Society, v. 305, p. 669, 1982. 
MOSELEY, H. G. I. “ The high frequency spectra of the elements”, Philophical Magazine, v.26, p. 1024-1034, 1912.

MOSSMAN, H. W. “Vertebrate fetal membranes”. New Brunswich, Rutgens University Press, pp. 387, 1987.

MYAKAYA, G.; SCHELLENS, J. P. M. Final stage of erythtophagocytosis in the sheep placenta. Cell Tissue Research, v. 214, p. 501-518, 1982.

NASCIMENTO, V. Técnica Analíticas nucleares de fluorescências de Raios $\mathbf{X}$ por Dispersão de Energia (ED- XRF) e por Reflexão Total (TXRF), 1999. Disponível em: WWW.cena.usp.br/apostila/virgilio/cen-5723/edxrf txrf.doc . Acesso em: dez.2009.

NRC. NATIONAL RESEARCH COUNCIL. Food and Nutrition Board/National Academy of Sciences. Recommended Dietary Allowances. 10th ed. Washington DC: NRC/FNB, 1989.

NAVARRO-ALARCÓN, M.; LÓPEZ-MARTINEZ, M. C. Essentiality of selenium in the human body: relationship with different diseases. Science of the total environment, v. 249, p. 347-371, 2000.

NICODEMO, M. L. F. Diagnóstico de deficiencies minerais em bovines. In: SIMPÓSIO GOIANO SOBRE PRODUÇÃO DE BOVINOS DE CORTE, 1999, Goiânia, Anais...Goiânia: CBNA, 1999, p. 57-80.

NICODEMO, M. L. F.; SERENO, J. R.B.; AMARAL, T.B. Minerais na eficiência reprodutiva de bovino. Empresa Brasileira de Pesquisa Agropecuária - Embrapa Pecuária Sudeste - São Carlos - SP, 2008, p. 18 - 51.

NIELSEN, F. H . Micronutrients and animal nutririon. ifa international.In: Symposium On Micronutrients, 2004, Nova Delli, India , 2004.

NILES, B. J.; CLEGG, M. S.; HANNA, L. A.; CHOU, S. S.; MOMMA, T. Y.; HONG, H.; KEEN, C. Zinc Deficiency-induced Iron Accumulation, a consequence of Alterations in Iron Regulatory protein-biding Activity, Iron transporters, and iron Storage proteins. Journal biology chemical, v. 283, tissue, 2008.

NIX, J. Trace minerals important for cattle reproduction. USA. Sweetlix Livestock Suplement System, 2002, p. I-800-325- I-486.

NOVAES, M. R. C. G.; ITO, M. K.; ARRUDA, S. F.; RODRIGUES, P.; LISBOA, A.Q. Suplementação de micronutrientes na senescência: implicações nos mecanismos imunológicos. Revista de Nutrição, Campinas, v. 18, n. 3, p. 367-376, 2005.

NRC. NATIONAL RESEARCH COUNCIL. Nutrient Requeriments of Dairy Goats. Washington: National Academy of the sciences, 2001. p. 154p.

O'DELL, B. L. Mineral-ion interation as assessed by bioavailability and ion channel function. In: . O'DELL , B. L.; SUNDE, R. A. (Ed.) Handdbook of nutritionally essential mineral elements. New York: Taylor \& Francis, 1997, p.641-659. 
OLIVEIRA, D. E. Minerais: funções, deficiências, toxidez e outros aspectos da suplementação. Agroceres Nutrição Animal . 2007. Disponível em: $<$ http://www.agroceresnutricao.com.br/ artigos/ apostilatecnicaminerais.pdf $>$. Acesso em: mar.2009.

OMS. ORGANIZAÇÃO MUNDIAL DE SAÚDE. Elementos traço na nutrição e saúde humana. São Paulo: Roca, p. 63-91, 1998.

PASCHOAL, C. L.; RAFAINE, D.; SANTOS, D. A. N.; ROCHA, F.P.C.; PASCHOAL NETO, F. A.; SACCO, S.R. Anemia por deficiência nutricional. Revista Cientifica Eletronica de Medicina Veterinária. Ano 6, n. 11, p. 1-8, 2008.

PEDREIRA, C. G. S.; MELLO, A. C. L. Bases para o estabelecimento de manejo de Cynodon sp para o manejo e conservação. In: PEIXOTO, A. M.; PEDREIRA, C. G. S., Piracicaba, Depto. de Física e Meteorologia; CENA, 1999, p. 32.

PEIXOTO, P.V.; MALAFAIA, P.; BARBOSA, J.D.; TORKANIA, C.H. Principios de suplementação mineral em ruminantes. Pesquisa Veterinária Brasileira, v. 25, n. 3, p. 195$200,2005$.

PENLAND, J. G.; PROHASKA, J. R. Abnormal Motor Function Persists Following Recovery from perinatal Copper deficiency in rats. Nutritional neurosciences. The Journal of Nutrition, v. 2, p. 1984- 1988, 2004.

PEREIRA, F. T. V. Eritrofagocitose placentária em búfalas (Bubalus bubalis bubalisSimpson, 1945). ano 2004. 102p. Tese (Doutorado) - Faculdade de Medicina Veterinária e Zootecnia, Universidade de São Paulo, São Paulo, 2004.

PEREZ, C. A.; RADTKE, M.;SANCHEZ, H. J.;TOLENTINO, H.; NEVENSHWANDER, R. T.; BRAG, A.; RUBIO, M.; BUENO, M. I. S.; RAIMUNDO, I. M.; ROHWEDDER, J. J. R. Synchrotron radiation X-Ray fluorescence at the LNLS: beamline instrumentation and experiments. X-Ray Spectrometry. v. 28, p. 320-326, 1999.

PINTO, L. M. Caracterização da célula binucleada na placenta de vacas nelore (Bos indicus-Linnaeus, 1758). 2002. p. 87. Tese (Doutorado) - Faculdade de Medicina Veterinária da Universidade de São Paulo, São Paulo, 2002.

POlettia, M. E., GOnCAlves, O. D., PEREZ, C. A., MAGAlhaES, S. D. A preliminary study ofthe distribution oftrace elements in healthy and neoplastic breast tissues with synchrotron radiation X-ray fluorescence. Radiation Physics and Chemistry, v. 71, p. 975-976, 2004.

POULSEN, H. D. Trace elements in animal nutrition. Danish Institute of Agricultural Sciences. NJF- Seminario n. 370, Reykjavík, Iceland, p.15-17, 2005.

PRASAD, A. S. Zinc deficiency in women, infants and children. Jounal of the American College of Nutrtion, v. 15, n. 2, p.113-120. 1996.

REISENBERGER, K.; EGARTER, C.; KAPIOTIS, S.; STERNBERGER, B.; GREGOR H \& HUSSLEIN, P. Transfer of erythropoietin across the placenta perfused in vitro. Obstet Gynecol, v. 89, p. 738-742, 1997. 
RIBEIRO, S. D. A. Criação racional de caprinos. São Paulo: Nobel, 1997.

RICHARDSON, C. In: ARTHUR, G.H.; NOAKES, D.E. PEARSON, H. Veterinary reproduction and obstetrics. 6. ed. London: Bailliére Tindal, 1989.

ROBERTS, R. M.; EALY, A. D.; ALEXENKO, A. P.; HAN, C. S.; EZASHI, T. Trophoblast interferons. Placenta, v. 20, p. 259-264, 1999.

RONG, Y.; DISTELHORST, C.W. Bcl-2 protein family members: versatile regulators of calcium signaling in cell survival and apoptosis. Annual Review Physiology. v. 70, p. 7391, 2008.

ROUSSEN, R. Detection limits and estimate of uncertainty of analytical XRF results. The Rigaku Journal, v. 2, p. 33-47, 2001.

SANTOS, J. E. P.; AMSTALDEN, M. Effects of nutrition on bovine reproduction. XIII Reunião Anual, SBTE. Atibaia, SP. In: Arquivo brasileiro de medina veterinária. UFRGS. Porto Alegre, RS. v. 26, n. 1, p. 19-89, 1998.

SMAILI, S.; HIRATA, H.; URESHINO, R.; MONTEFORTE, P. T.; MORAES, A. P.; MULER, M. L.; TERASHIMA, J.; LOPES, G. S.; BINCOLETTO. Calcium and cell death signaling in neurodegeneration and aging. Anais.... v. 81, n. 3, p. 467-475, 2009.

SARIS, N. E.; MERVALA, E; KARPPANEN, H.;KHAWAJA, J. A.; LEWENSTAM, A. Review. Magnesium an update on physiological, clinical and analytical aspects. Clinica Chimica Acta, v. 194, p. 1-26, 2000.

SCHENKER, S.; YANG, Y.; MATTIUZ, E.; TATUM, D. \& LEE, M. Olanzapine transfer by human placenta. Clinical and Experimental Pharmacology and Physioloy, v. 26, p. 691-697, 1999.

SCHMIDT-NIELSEN, K. Fisiologia animal: adaptação e meio ambiente. 5. ed. São Paulo: Santos, 2002, p. 600.

SCHWARTZ, K.; FOLTSZ, P. J. Selenium as an integral part of factor 3 against dietary necrotic liver degeneration. Jounal. America Chemical Society, v. 79, p. 200-214, 1957.

SERGEANT, C.; VESVRES, M. H.; DEVES, G.; GUILLOU, F. Calcium, potassium, iron, copper and zinc concentration in the white and gray matter of the cerebellum and corpus callosum in braisn of four genetic mouse strain. Nuclear Instruments and Methods in Physicus Research B, v. 231, p. 234-238, 2005.

SERPA, R.; JESUS, E.; ANJOS, M.; "Elemental concentration in the cortex and hippocampus of wistar rats by x-ray total reflection fluorescence with synchrotron radiation". Journal of Radioanalytical and Nuclear Chemistry, v. 269, p. 647-652, 2006.

SILVA, L. S .V.; THIAPÓ, A. P.; SOUZA, G. G.; SAUNDERS, C.; RAMALHO, A. Micronutrientes na gestação e lactação. Revista Brasileira Saúde Maternal , v. 7, n. 3, p. 237-244, 2007. 
SILVA, R. Utilização de técnica de fluorescência de raios $\mathbf{X}$ com microsonda ( $\boldsymbol{\mu}$-XRF) aplicada a amostra de interesse arqueológico. 2002. 103 p. Tese (Doutorado) Universidade de São Paulo, Centro de Energia Nuclear na Agricultura, São Paulo, 2002.

SIMMS, D. D.; BLASI, D. A.; BOLZE, R. P.; BRAZLE, F. K.; CORAH, L. R.; ECK, T. P.; KUHL, G. L. Beef cow nutrition guide. Cooperative Extension Service, Kansas State University, 1993. Disponível em: <http://www.oznet.ksu.edu/library/lvstk2/c735.pdf>. Acesso em: abr. 2009.

SINGH, B.; DHAWAN, D.; CHAND,B.; MAGAL, P. C.; TREHAN, P. N. Trace elements distribution in rat brain following lead and lithium supplementation. A study using an EDXRF Spectrometer. Applied Radioation and Isotopes, V. 46, p. 59-64, 1995.

SOUZA, A. S. R.; NORONHA, N. C.; COSTA, M. O. L. P.; LIMA, M. M. S.; DINIZ, C. C. P. Trocas materno-fetais dos eletrólitos. Femina, v..35, n. 11, p. 737-741, 2007.

SUTMOLlER, P.; ABREU,A. V.; GRIFT, J. VAN DER; SOMBROEK W. G. Mineral imbalance in cattle in the Amazon valley. Amsterdan: Departament Agricule Communication, 1966. (Communication, n. 35)

SUTTLE, N. F.; JONES, D. G. Recent developments in trace element metabolism and function: trace elements, disease resistance and immune responsiveness in ruminants. Journal of Nutrition, v. 119, n. 7, p. 1055-1061, 1989.

TAKAHASHI, H.; TANAKA, S.; SANO, K., "Changes In Extracellular Potassuim Concentration In Cortex and brain stem during the acute phase of experimental closed head injury”. Journal of Neurosurgery, v. 57, p. 667-675, 1981.

TOWNS, J. K. Moisture content in protein: its effects and measurement. J. Chromat., v. 705,p. 115-127, 1995.

TUFAN, A. C. A.; AKDOGAN, I. B.; TURGUT, G.; ADIGUZEL, E. Increased Tunel Positive Cells in CA1, CA2, and CA3 Subfields of Rat Hippocampus Due to Copper and Ethanol Co-Exposure. International Journal of Neuroscience, v.118, p. 647-656, 2008.

UAUY, R.; OLIVARES, M.; AND GONZALEZ, M. Essentiality of copper in humans. America Journal Clininical Nutrition. v. 67, p. 952S-959S, 1998.

ULlREY, D. E.; BRADY, P. S.; WHETTER, P. A.; KU, P. K.; MAGEE, W. T. Selenium supplementation of diets for sheep and beef cattle. Jornal Animal Science, v. 46, p. 559, 1977.

UMBElinO, D. C.; ROSSI, E. A. Deficiência De Ferro: Consequencias Biologicas E Propostas De Prevenção. Revista Ciências Farmacéutica Básicas, v. 27, n. 2, p. 103-112, 2006.

UNDERWOOD, E. J. Los minerales en la nutrición del gado. 2. ed. Zaragoza: Acribia, 1981.

UNDERWOOD, E. J.; SUTTLE, N. F. The Mineral Nutrition of Livestock, 3. ed. Oxon, United Kingdom, CABI Publishing, 1999. 
VALKO, M.; LEIBFRITZ, D.; MONCOL, J.; CRONIN, M. T. D.;MAZUR, M.; TELSER, J. Free radicals and antioxidants in normal physiological functions and human disease. The International Journal of Biochemistry and Cell Biology, v. 39, p. 44-84, 2007.

VALLEE, B. L. e FALCHUK, K. H. The biochemical basis of zinc physiology. Physiological Review, v. 73, n. 1, p. 79-118. 1993.

WALTER, P. B.; KNUTSON, M. D.; PALER-MARTINEZ, A.; LEE, S.; XU, Y.; VITERI, F. E.; AMES, B. N. Iron deficiency and iron excess damage mitochondria and mitochondrial DNA in rats. Medical Sciences. Proceding of the nathional Academy of Science, USA, v. 99, n. 4, p. 19, 2002.

WATT, F.; LANDSBERG, J. “ Nuclear microscopy: biomedical applications”, Nuclear Instruments \& Methods in Physics Research B, v. 3, p. 232-240, 1993.

WEISINGER, J. R.; BELLORI, E. 1998. Magnesium and phosphorus. Lancet, v. 352, p. 391-396, 1998.

WELLS, D. N.; MISICA, P. M.; TERVIT, H. R. Production of cloned calves following nuclear transfer with cultured adult mural granulosa cells. Biology of Reproduction, v. 60, p. 996-1005, 1999.

WHITE, I. G.; VISHWANATH, R.; SWAN, M. A.; BROWNWOODMAN, P. D. Studies of the mechanism of action of gossypol as a male antifertility agent. Contraception, v. 37, n. 3, p. 269-277, 1988.

WIDDOWSON, E. M.; DANCEY, J.; SHAW, J .L. C.; Trace elements in foetal and early postnatal development. Proceding Nutrition Society., v. 33, p. 275-284, 1974.

WINICK, H., DONIACH, S. Synchrotron radiation research. New York: Plenum Press, 1980, p. 754.

WISLOCKI, G. B.; DEMPSEY, E. W. Histochemical reaction in the placenta of the cta. American Journal of Anatomy, v.78, p. 7-37, n.1, 1946.

WOLF, F. I.; TORSELlO, A.; FASANELLA, S.; CITTADINI, A. Cell physiology of magnesium. Mol Aspects Med. v. 24, n. 1-3, p. 11-26, 2003

WRIGHT, W. E.; PETERS, J. M.; MACK, T. M . Leukaemia in Workers exposen to electrical and magnetic fields. Lancet, v. 5, p. 160- 231, 1982.

YOUDIM, M.B.; BEN-SHACHAR, D.; YEHUDA, S. Putative biological mechanisms of the effect of iron deficiency on brain biochemistry and behavior. America Jounal Clinical Nutrition, v. 50, p. 615-617, 1989. 
- Prexes 


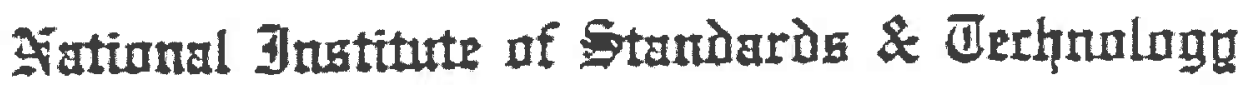

\section{UTertifitate af Analugit}

\section{Standard Reference Material 1577b}

\section{Bovine Liver}

This Standard Reference Material (SRM) is inteoded primerify to use as a coatrol material and in evalusting anatytical methods for the determinutien of mojor, mion, and trice elemens in inimal tivene and other biologieal matrices.

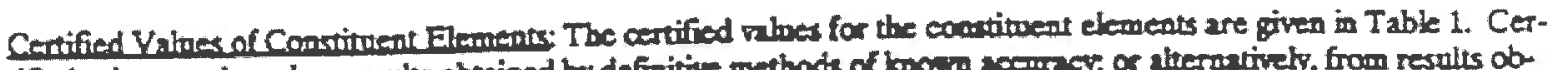

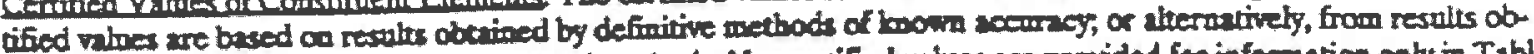
tained by two or more independent matytical metbods. Noocertified vitues are provided for information onty in Table 2

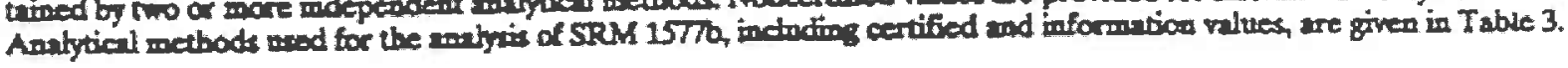

\section{Notice and Namines to Usas:}

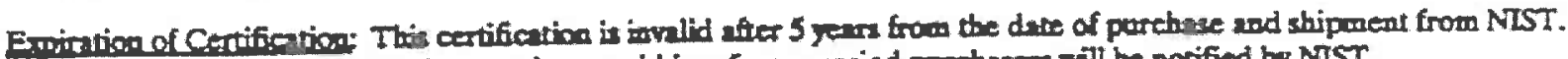

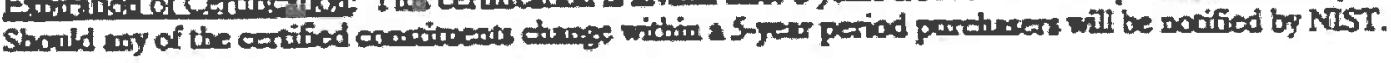

Stabitity The SRM thould be kept in is criginal bottle and anred between 10-30 $\mathrm{C}$. It thould sot be exposed to in-

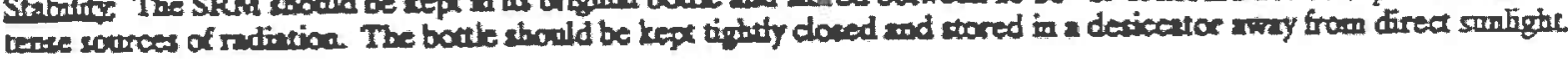

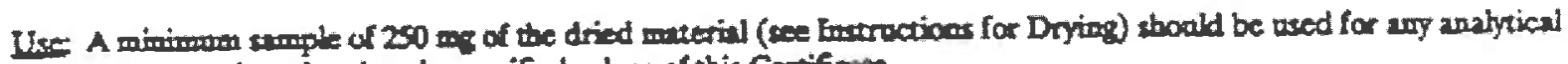

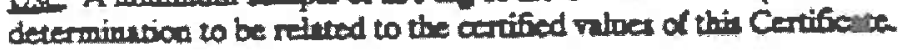

Dissotation procedures should be decigned to effec complete solution, but witbour bries of volatile elemeats, such as

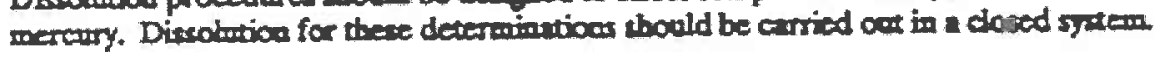

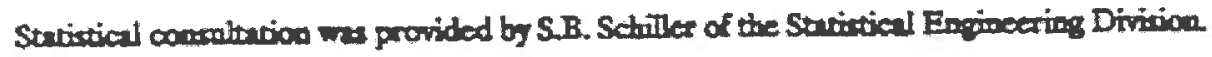

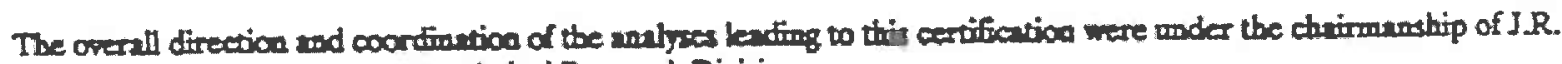

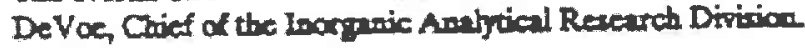

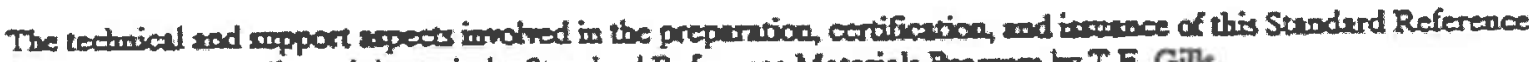
Muterill were coordianted through the Standurd Reference Materiats Prograss by T. E Gilis.

Gathershurg MD 20899

Algot 27, 1991
Wilinem P. Reed, Chic Stendard Reference Materials Frogran 
Table ic Cerrified Values of Constinued Elements

\begin{tabular}{|c|c|}
\hline Elment & $\begin{array}{c}\text { Contear } \\
\text { (on. nersenel) }\end{array}$ \\
\hline $\begin{array}{l}\text { Chlorioe } \\
\text { Phosphorns } \\
\text { Pokassinm } \\
\text { Sodium }\end{array}$ & $\begin{array}{l}0.278 \pm 0.006 \\
2.10 \pm 0.03 \\
0.994 \pm 0.000 \\
0.20 \pm 0.006\end{array}$ \\
\hline Salfur & $0.785 \pm 0.006$ \\
\hline
\end{tabular}

\begin{tabular}{|c|c|c|c|}
\hline 7 & \multicolumn{3}{|c|}{$\begin{array}{l}\text { Costent } \\
(\mu \operatorname{sis})\end{array}$} \\
\hline ind & 0.50 & \pm & 0.03 \\
\hline 8 & 116 & \pm & \\
\hline Copper & 160 & \pm & 8 \\
\hline rad & 184 & \pm & 15 \\
\hline Lead & $\frac{0.129}{601}$ & \pm & $\frac{0.004}{28}$ \\
\hline
\end{tabular}

\begin{tabular}{|c|c|c|}
\hline Element & \multicolumn{2}{|c|}{$\begin{array}{l}\text { Content } \\
(\alpha \nabla / 2)\end{array}$} \\
\hline dolybdeoum & 3.5 & 03 \\
\hline Rubifium & 13.7 & ar \\
\hline Silent & 0.73 & \pm 0.06 \\
\hline Strostingm & 0.136 & \pm 0.001 \\
\hline inc & & \pm 16 \\
\hline
\end{tabular}

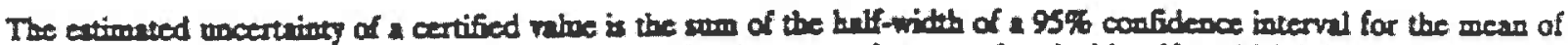

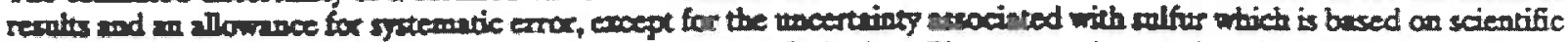

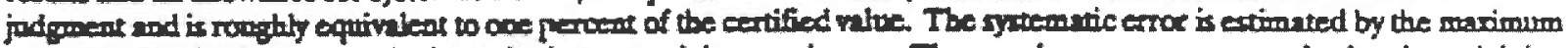

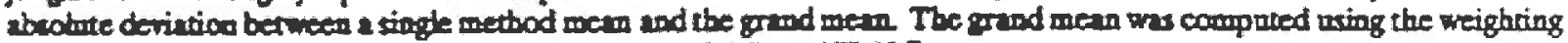
scheore of Palle and Mandel (NBS Joernl of Reseurch 87, pp 377-385).

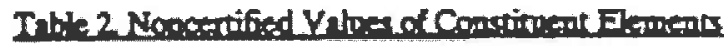

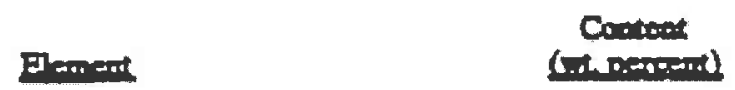

Nitroger

(106)

\begin{tabular}{|c|c|c|c|}
\hline Element & $\begin{array}{l}\text { Conent } \\
(\mu \rho t p)\end{array}$ & Elem=at & $\begin{array}{l}\text { Contede } \\
\text { Surterl }\end{array}$ \\
\hline $\begin{array}{l}\text { Arncosic } \\
\text { Almowion }\end{array}$ & $\begin{array}{l}(a, s) \\
(3)\end{array}$ & $\begin{array}{l}\text { Cobult } \\
\text { Vanidinem }\end{array}$ & $\begin{array}{l}(0.25) \\
(0.123)\end{array}$ \\
\hline $\begin{array}{l}\text { Antimary } \\
\text { Brocenios } \\
\text { Mercory }\end{array}$ & $\begin{array}{l}(0003) \\
(9.7) \\
(0,003)\end{array}$ & & \\
\hline
\end{tabular}

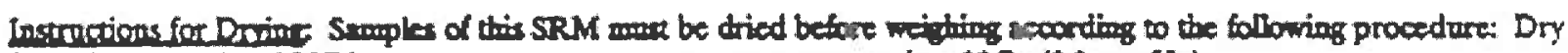

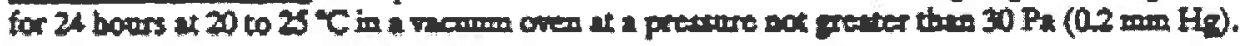

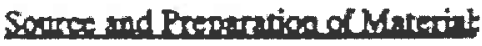

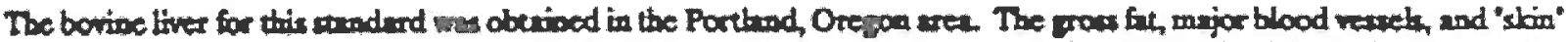

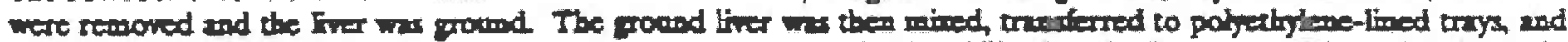

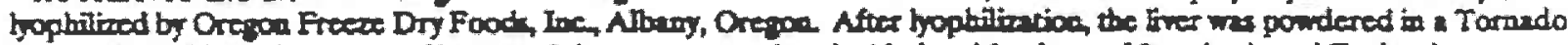

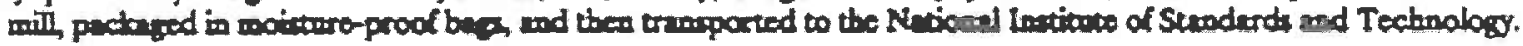


Table 3.

Anatytial Methods. Used for the Antissis of SRM 1507 .

Method

Elements Deteronined

ETAAS

FES

ICP

GFAAS

DCP

IC

IDTMMS

IDSSMCS

INAA

RNAA

POL

Color

Keldint

CVAAS

FAAS
A. $\mathrm{Cd}, \mathrm{As}, \mathrm{CO}$

$\mathrm{C}_{4}, \mathrm{~N}+\mathrm{SF}$

$\mathrm{C}_{2} \mathrm{Cr}, \mathrm{Fe}, \mathrm{Mg} \mathrm{Mr}, \mathrm{Zn}, \mathrm{Sr}$

$\mathrm{Cn}, \mathrm{Mn}, \mathrm{Rb}, \mathrm{Zn}$

$\mathbf{P}$

Q.s

L. Pb, Rb, S, S r

$\mathrm{Cd}, \mathrm{Cr}, \mathrm{Mo}, \mathrm{Se}, \mathrm{Zn}$

C, Co, Fe, Mn, Na, Rb, Se, Zn, Al, Br, Co, K, V, Mg, Ag

As, As, Cd, Ca, $\mathrm{Hg}, \mathrm{Mo}, \mathrm{Se}, \mathrm{Sb}$

Fe

$\mathbf{P}$

$\mathbf{N}$

He

C.Mr

ETAAS: Electrothermal atomic abcorption spectronecy

FES: Fine atomic emition spectrometry

ICP. Inductivty coupled piesm emivion spectrometry

GPAAS: Grophice furnoce toonic absoption spectrometry

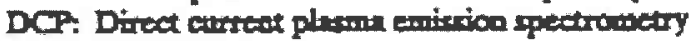

IC Io chromerography

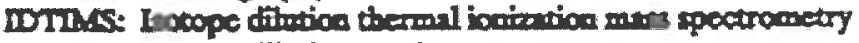

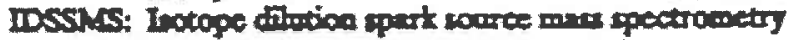

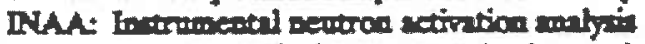

RNAA: Refiochemical nectron actirition andy is

POL: Pobrompty

Color: Spectiopbotometry

Geldatit Titrienety

CVAAS: Cold Vapor Atomic Abrorption Spectrometry

FAAS: Flamo Atosic Abeorption Spectroustry

Ambatre

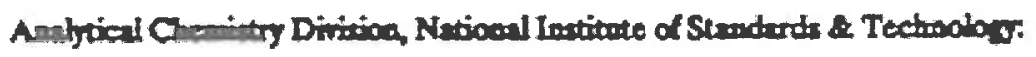

LI.V. Betay

2 LI Bare

3. ES. Bong

4. CG. Blonde

5. LA Britetic

6. TA Butia

7. ER DerdarI

8. MS Eptei

9.JW, Grmash

10. R.R. Grocebor:

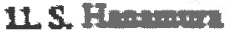

12. SII. Humivon

13. EF. Hend

14. WR Xelly
15. HM. Kingeon

16. W.F, Koch

17. GM L Labert

18. RM. Lintitron

19. GJ. Loe

20. LA Minchion

21. EJ. Mrienthal

2 T.. Murp'y

23. P. Puntiea

24. LI. Pom

25. TCR R

26. TA Rush

27. R.L Weters Jr.

2. R. Zetules 

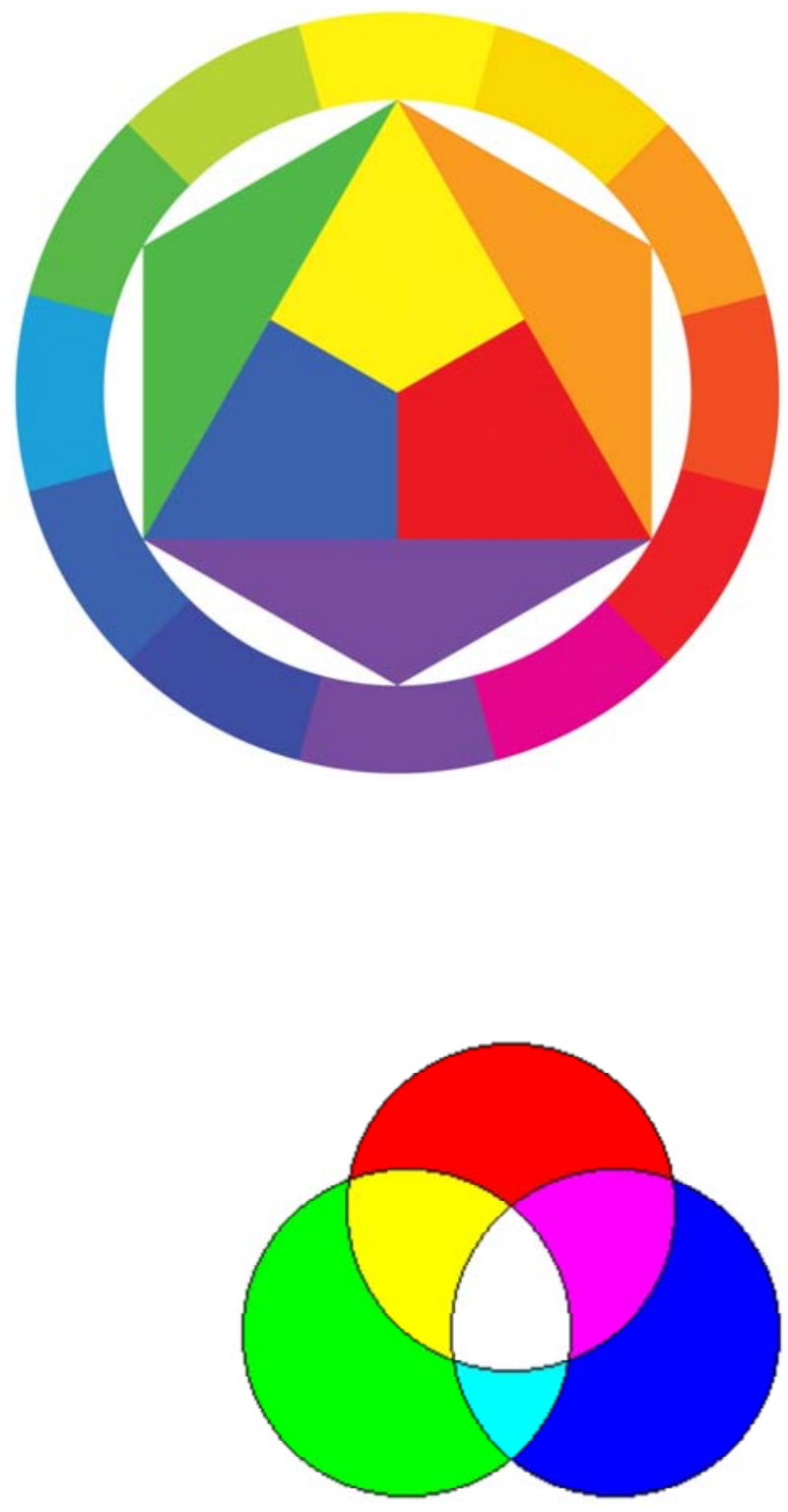